\title{
Habitat ecology and long-term development of the macrophyte vegetation of north-west German streams and rivers since the 1950s
}

Dissertation zur Erlangung des Doktorgrades der Mathematisch-Naturwissenschaftlichen Fakultäten der Georg-August-Universität Göttingen

\author{
vorgelegt von \\ Kristina Steffen \\ aus Eckernförde
}

Göttingen, 2013 
Referent: Prof. Dr. Christoph Leuschner

Korreferent: Prof. Dr. Markus Hauck

Tag der mündlichen Prüfung: 28.5.2013 
„Krickerode war rechtskräftig verurteilt worden. Das Erkenntnis untersagt der großen Provinzfabrik bei hundert Mark Strafe für jeden Kalendertag, das Mühlwasser von Pfisters Mühle durch ihre Abwässer zu verunreinigen und dadurch einen das $\mathrm{Maß}$ des Erträglichen übersteigenden übeln Geruch in der Turbinenstube und den sonstigen Hausräumen zu erzeugen, sowie das Mühlenwerk mit einer den Betrieb hindernden, schleimigen, schlingpflanzenartigen Masse in gewissen Monaten des Jahres zu überziehen.“

(Wilhelm Raabe in „Pfisters Mühle“, 1884) 


\section{Summary}

This $\mathrm{PhD}$ thesis deals with the habitat characterization and the long-term development over 60 years of the macrophyte vegetation of north-west German running waters in order to contribute to the knowledge about the ecology of aquatic macrophytes and make use of them as bioindicators. Seventy streams and rivers in the regions Ems-Hunte moraine, Lüneburg Heath, Aller lowlands, northern Harz foothills, base of the Weser-Leine uplands and eastern Holstein were investigated, the emphasis though is on the cross-regional scale. From the analysis of the composition and distribution of the macrophyte communities in relation to river size and physical and chemical water and sediment properties could be concluded that water course depth and current velocity are the most decisive variables for the community composition nowadays, followed by the content of plant-available phosphorus in the sediment. However, it is possible that several decades ago, before the strong intensification of agricultural land-use taking place in the study area since the 1950s, when more pronounced gradients in the nutrient concentrations of running waters existed, chemical variables had a stronger influence on the macrophyte occurrences than today.

By means of a semi-permanent plot approach, the vegetation change between the 1950s and 2010 was investigated, revealing a dramatic decline in species diversity (the overall species pool declined by $27.5 \%$ from 51 to 37 hydrophytic species, plot-level richness by $19.4 \%$ from 4.7 to 3.8 species per relevé), accompanied by a profound shift in community composition from the predominance of potamid species to the predominance of lemnid species. Oligotraphent species such as Potamogeton gramineus and $P$. polygonifolius died out in the study sites and the mesotraphent species Myriophyllum alterniflorum and Ranunculus peltatus declined in their frequency of occurrence by more than $50 \%$, whereas the eutraphent species Myriophyllum spicatum and Spirodela polyrhiza increased by more than $100 \%$. In addition, a change in the species traits leaf longevity and specific leaf area (SLA) was found: in the historical macrophyte communities from the 1950s, evergreen species and species with leaves being thin or rich in air-filled lacunae were abundant, while the recent vegetation from 2010 was characterized by summergreen species with a robust structure (low SLA). On the regional scale, the changes in species composition were most profound in the Ems-Hunte moraine country, where drainage of fens and bogs preceded highly intensive land-use especially since the embankment of the Dümmer lake (1953), and less pronounced in the Lüneburg Heath region, where lowland water courses with a natural structure can still be found.

On the syntaxonomic level, the application of two different phytosociological classification systems revealed deep changes in the macrophyte community structure over six decades. All relevés from vegetated reaches could be assigned to one of the classes 
Potamogetonetea, Lemnetea, Phragmitetea or Fontinalietea. While Batrachietalia/Batrachion and Potamogetonetalia/Potamogetonion stands strongly decreased, Nymphaeetalia /Nymphaeion communities gained importance. The observed increase in phytosociologically weakly characterized stands ('residual communities') implies losses of highly specialized species. Average similarity was significantly higher in the recent $\left(S_{B C}=0.25\right)$ than in the historical (0.22) assemblages, revealing a homogenization of the macrophyte vegetation of north-west German water courses.

The most likely causes of the decline in the macrophyte species and community richness and diversity are accelerated eutrophication processes and river regulation measures, that caused uniformization of the running water habitats in the intensively managed cultural landscape, and regular disturbance. Ongoing efforts to reduce the nutrient loads, as well as the enhancement of the habitat heterogeneity by renaturalizing the structure of the water courses and ecologically compatible weed-cutting techniques and dates are necessary to halt and reverse the diversity decline in the macrophyte vegetation of north-west German streams and rivers. Diverse vegetation stands are an essential element in running water ecosystems, whose functionality is relevant, not least for human welfare. 


\section{Zusammenfassung}

Diese Arbeit behandelt die Charakterisierung der Habitate und die Langzeit-Entwicklung über sechs Jahrzehnte der Makrophytenvegetation nordwestdeutscher Bäche und Flüsse, um zum Wissen über die Ökologie aquatischer Makrophyten beizutragen und sie als Bioindikatoren zu nutzen. Siebzig Bäche und Flüsse der Regionen Ems-Hunte Geest, Lüneburger Heide, Allerflachland, nördliches Harzvorland, Fuß des Weser-Leine Berglandes und ostholsteinisches Hügelland sind Bestandteil der Studie, wobei der Schwerpunkt auf der überregionalen Betrachtungsebene liegt. Aus der Analyse der Zusammensetzung und Verbreitung der Makrophytengesellschaften im Zusammenhang mit Gewässergröße und physikalischen und chemischen Wasser- und Sedimenteigenschaften schlossen wir, dass Gewässertiefe und Fließgeschwindigkeit von den gemessenen Variablen den größten Einfluss auf die heutige Gesellschaftszusammensetzung haben, gefolgt vom Gehalt pflanzenverfügbaren Phosphors im Sediment. Es ist jedoch nicht auszuschließen, dass vor der im Untersuchungsgebiet seit den 1950ern stattfindenden, starken Intensivierung der landwirtschaftlichen Nutzung, als noch ausgeprägtere Gradienten bei den Nährstoffgehalten der Fließgewässer existiert haben, chemische Größen einen stärkeren Einfluss auf die Makrophytenvorkommen hatten als heute.

Mittels semi-permanenter Dauerflächen haben wir den Vegetationswandel zwischen den 1950ern und 2010 untersucht und einen dramatischen Rückgang der Artenvielfalt festgestellt (der Gesamtartenpool sank um $27.5 \%$ von 51 auf 37 Hydrophytenarten, die Artenzahl pro Aufnahmefläche um $19.4 \%$ von 4.7 auf 3.8 Arten), begleitet von einem umfassenden Bestandsumbau vom Vorherrschen wurzelnder (v.a. potamider) Arten zur Dominanz freischwimmender (v.a. lemnider) Arten. Oligotraphente Arten wie Potamogeton gramineus und $P$. polygonifolius sind in den Probeflächen ausgestorben und die mesotraphenten Arten Myriophyllum alterniflorum und Ranunculus peltatus in ihrer Auftretenshäufigkeit um mehr als $50 \%$ zurückgegangen, während die eutraphenten Arten Myriophyllum spicatum und Spirodela polyrhiza um mehr als $100 \%$ zugenommen haben. In den Artmerkmalen Blattausdauer und spezifische Blattfläche (SLA) wurden Änderungen festgestellt: In den historischen Makrophytenbeständen der 1950er waren immergrüne Arten und Arten mit dünnen Blättern oder solchen mit viel arenchymatischem Gewebe häufig (große SLA), während die rezenten Bestände von 2010 durch sommergrüne Arten und solche mit robuster Struktur (geringe SLA) gekennzeichnet sind. Die Veränderungen in der Artenzusammensetzung waren am tiefgreifendsten in der Region Ems-Hunte Geest, wo weitläufige Niedermoore durch Entwässerung insbesondere seit der Eindeichung des Dümmer Sees (1953) intensiv bewirtschaftetem Agrarland gewichen sind, und weniger 
ausgeprägt in der Lüneburger Heide, einer der wenigen Tieflandsregionen Deutschlands, in der noch Fließgewässer mit kaum durch den Menschen veränderter Struktur zu finden sind.

Auf der syntaxonomischen Ebene zeigte die Anwendung zweier unterschiedlicher pflanzensoziologischer Klassifikationssysteme tiefe Veränderungen in der Struktur der Makrophytengesellschaften über sechs Jahrzehnte auf. Alle dokumentierten Vegetationsbestände konnten einer der Klassen Potamogetonetea, Lemnetea, Phragmitetea oder Fontinalietea zugeordnet werden. Während Batrachietalia/Batrachion und Potamogetonetalia /Potamogetonion-Bestände stark zurückgegangen sind, haben Nymphaeetalia/NymphaeionGesellschaften zugenommen. Die beobachtete Zunahme pflanzensoziologisch schwach charakterisierter Bestände (Fragmentgesellschaften) deutet auf Verluste bei den hochspezialisierten Arten hin. Im Schnitt waren sich die rezenten Vegetationsbestände signifikant ähnlicher $\left(\mathrm{S}_{\mathrm{BC}}=0.25\right)$ als die historischen (0.22), was eine Homogenisierung der Fließgewässervegetation Nordwestdeutschlands offenbart.

Beschleunigte Eutrophierungsprozesse in den Gewässern und wasserbauliche Maßnahmen in der intensiv genutzten Kulturlandschaft haben zu einer Uniformierung der Fließgewässerhabitate geführt, worin neben häufigen Störereignissen die Hauptursache für die Verluste in Artenreichtum und Vielfalt der Makrophytenvegetation gesehen werden kann. Weitere Anstrengungen zur Reduzierung der Nährstofffrachten, sowie eine Erhöhung der Habitatheterogenität durch strukturverbessernde Renaturierungsmaßnahmen und ökologisch verträgliche Unterhaltungstechniken und -zeitpunkte sind notwendig, um den Diversitätsrückgang in der Makrophytenvegetation nordwestdeutscher Bäche und Flüsse aufzuhalten und umzukehren. Eine artenreiche Vegetation ist ein wichtiger Baustein in FließgewässerÖkosystemen, deren Funktionsfähigkeit nicht zuletzt auch für das menschliche Wohlergehen von Bedeutung ist. 


\section{Contents}

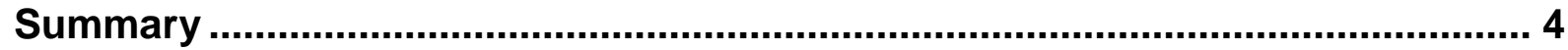

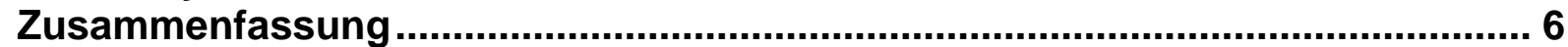

\section{Chapter 1}

General introduction .................................................................................. 11

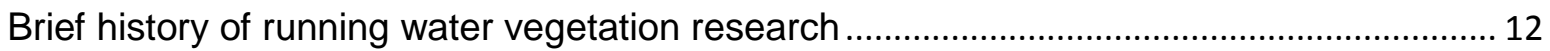

Evolution and physiological characteristics of aquatic macrophytes ...................................... 12

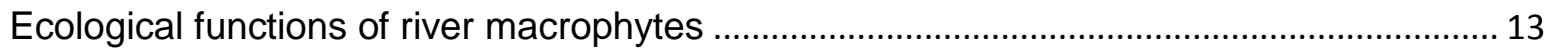

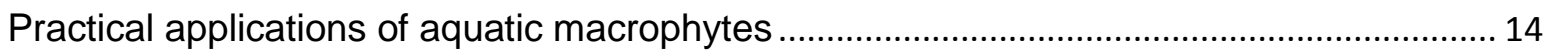

Threats to the phytodiversity in running waters: eutrophication and alterations of the

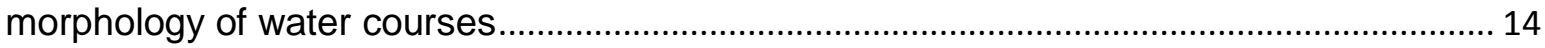

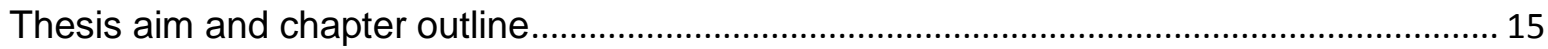

The study area: geology, climate and human influence .......................................................... 16

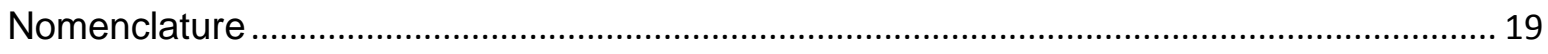

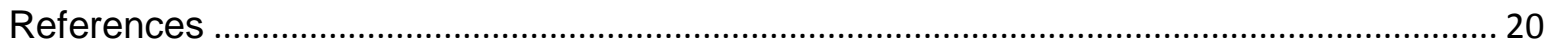

\section{Chapter 2}

Relationships between macrophyte vegetation and physical and chemical conditions in north-west German running waters

Kristina Steffen, Christoph Leuschner, Uta Müller, Gerhard Wiegleb \& Thomas Becker

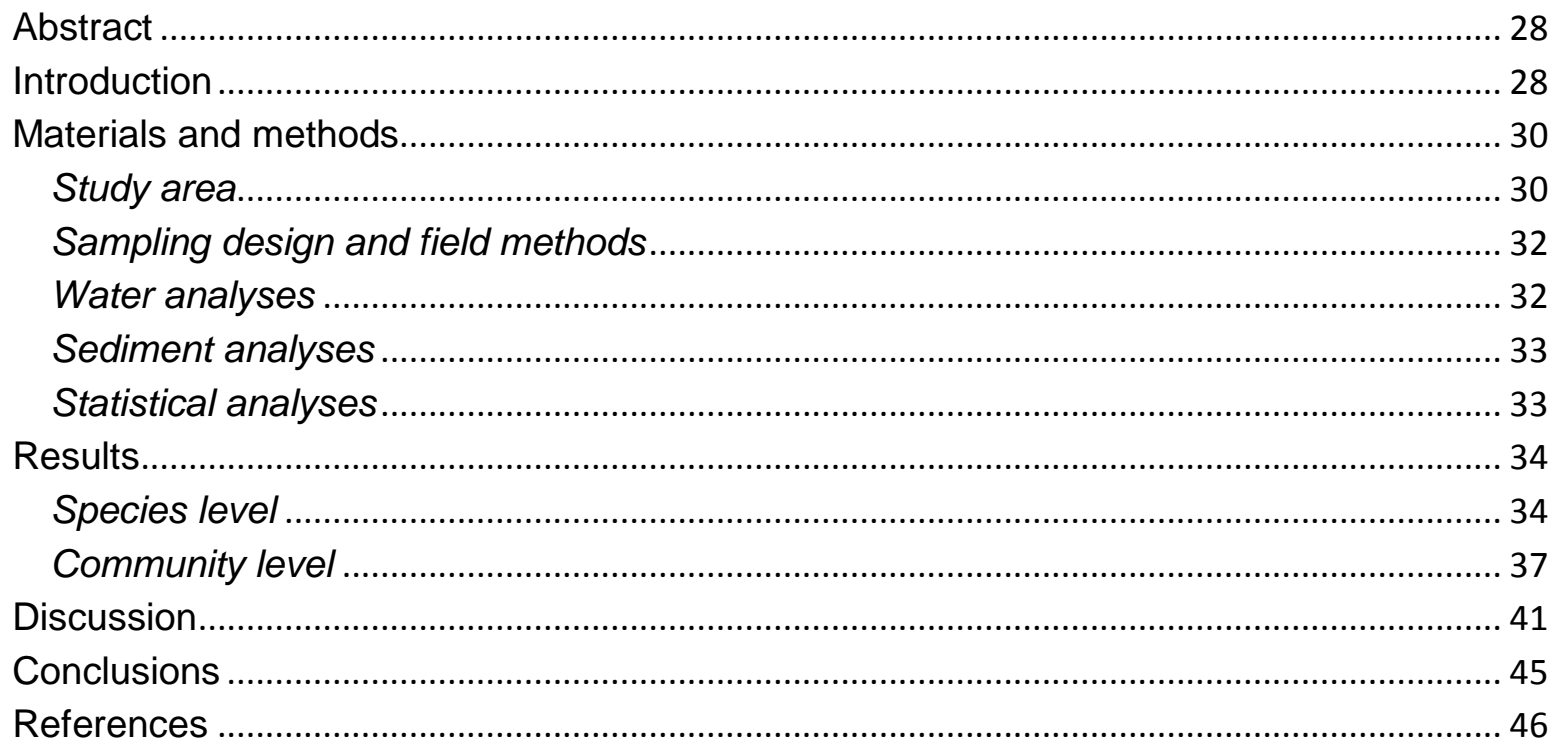

\section{Chapter 3}

Diversity loss in the macrophyte vegetation of north-west German streams and rivers between the 1950s and 2010

Kristina Steffen, Thomas Becker, Wolfgang Herr \& Christoph Leuschner

Abstract
Introduction
$\quad$ Study area
Data basis 


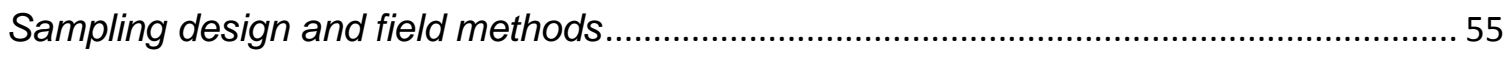

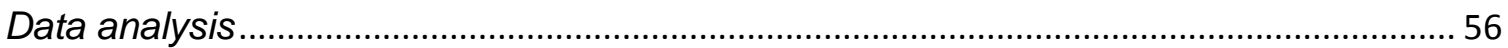

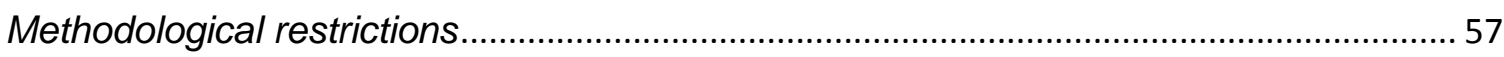

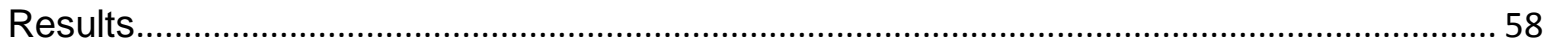

Change in floristic composition and diversity between the 1950s and 2010/2011 ........... 58

Change in environmental conditions between the 1950s and 2010/2011 .........................63

Time course of community change: comparing the 1950s, the 1980s and 2010/2011 ... 64

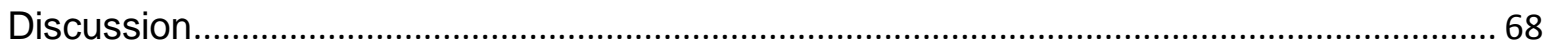

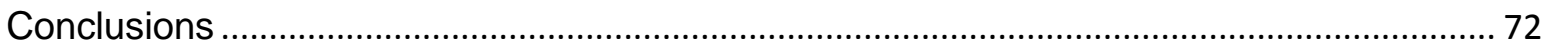

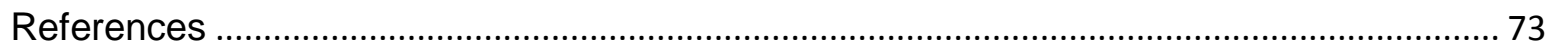

\section{Chapter 4}

Sixty years of change in the macrophyte vegetation of north-west German running waters: a community- and landscape-level analysis

Kristina Steffen \& Christoph Leuschner

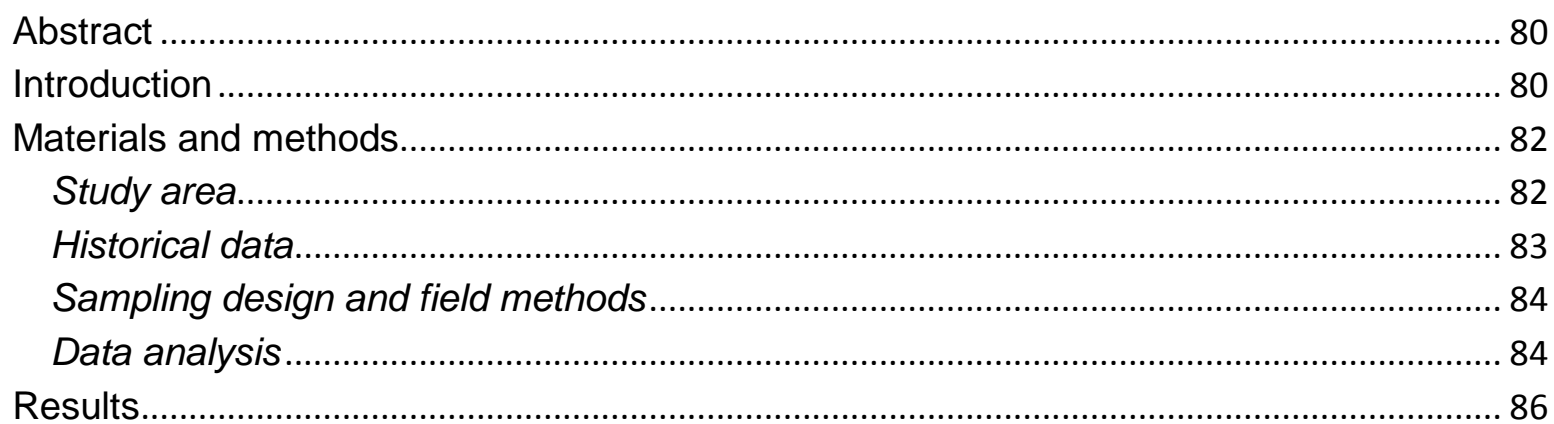

Vegetation change in river macrophyte assemblages over 60 years as revealed by the

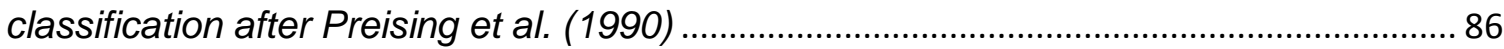

Vegetation change as revealed by the classification system after Chytrý (2011) ............ 88

Environmental change at the community level since the 1950s ....................................... 91

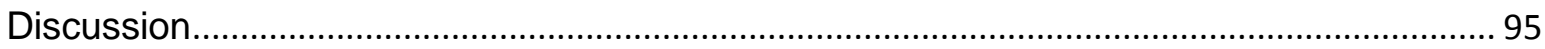

Weaknesses and strengths of the sampling and classification approaches ...................... 95

Landscape-scale diversity of macrophyte assemblages in historical and recent time .... 96

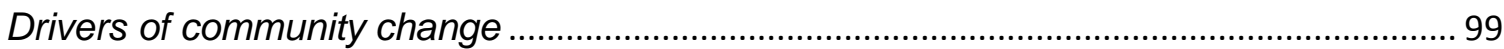

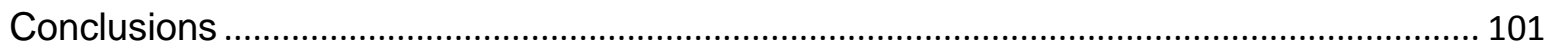

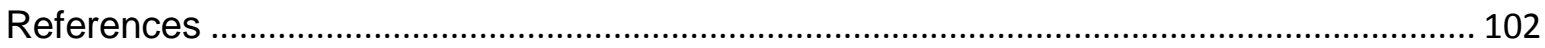

Chapter 5

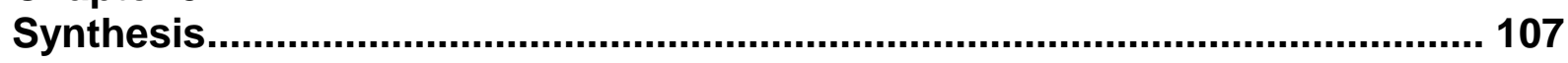

Methodological remarks: assessing long-term vegetation change in running waters with

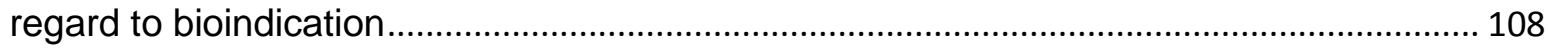

Vegetation and environmental change in streams and rivers in north-west Germany since

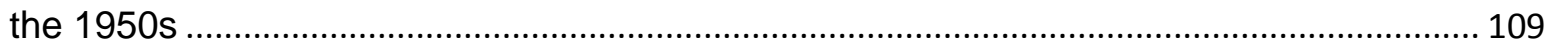

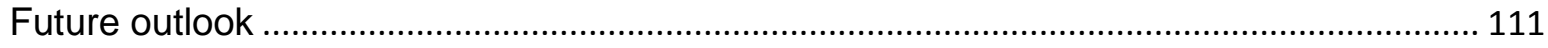

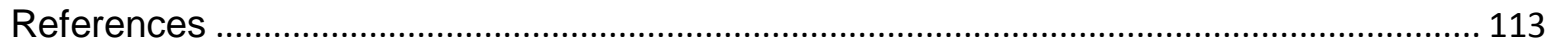

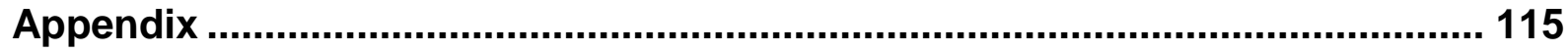

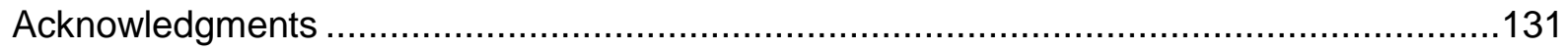


Chapter 1

\section{General introduction}
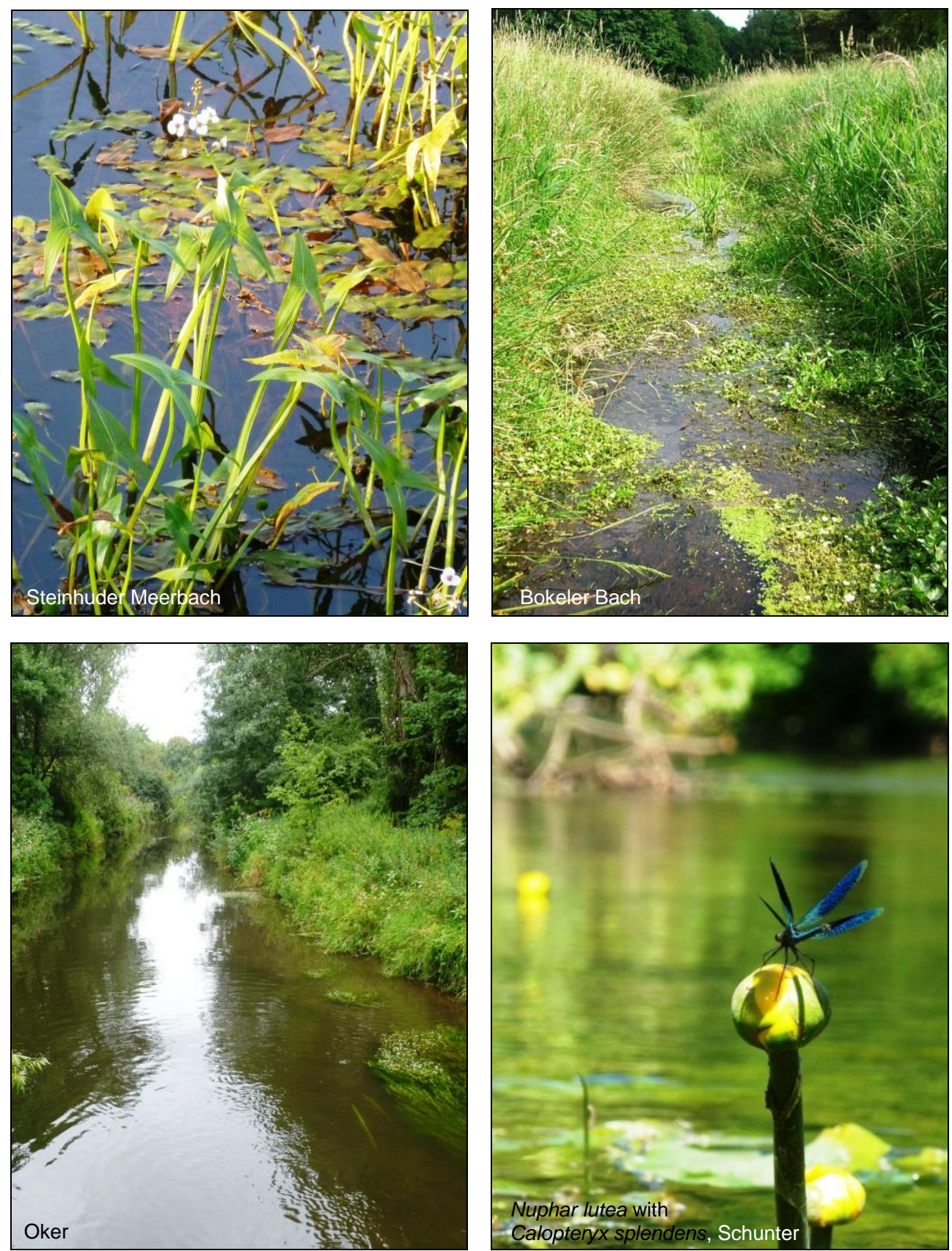


\section{Brief history of running water vegetation research}

A macrophyte is an "aquatic photosynthetic organism, large enough to see with the naked eye, growing permanently or periodically submerged below, floating on, or up through the water surface" (Chambers et al. 2008). The earliest studies on freshwater macrophytes deal for example with aspects of taxonomy, toxicity, life history and leaf anatomy (Pulteney 1800, Palisot de Beauvois 1816, Kützing 1832, Tuckerman 1849, Sauvageau 1891). Limnology [Greek: $\lambda i ́ \mu v \eta$ ('limnh') = lake], the scientific study of freshwater ecosystems, is a specialization of ecology with the first textbook by Forel (1901) being available at the beginning of the twentieth century. Since the foundation of the International Society of Limnology (Societas Internationalis Limnologiae) in 1922, running water research is explicitly incorporated in this field (Schwoerbel 1993). The first monographic studies on running water macrophyte vegetation as related to different habitat qualities originate from Central Europe (Tansley 1911, Koch 1926, Butcher 1927, Horvatić 1931, Roll 1939, Steusloff 1939), North America (Muenscher 1931, Thomson 1944, Moyle 1945, Jones 1955) and South Africa (Weintroub 1933), bearing the seeds for the application of aquatic plants as bioindicators. With the inspection of the vegetation of tropical rivers (Lebrun 1947, Cook 1968) also the observed spread of tropical aquatic weeds as for example Eichhornia crassipes came into focus (Bard 1965, Bennett 1967). The classification system of aquatic plant taxa into life form (e.g. pleustophytic or rhizophytic) and growth form types (e.g. ceratophyllid, nymphaeid or batrachid) was basically developed by Glück (1924), Luther (1949), Den Hartog \& Segal (1964) and Mäkirinta (1978). By now, taxonomical questions in some genera as for example Potamogeton (Wiegleb \& Kaplan 1998, Preston 1995), Callitriche (Schotsmann 1967, Dersch 1987, Lansdown 2006) and Ranunculus (Cook 1966, Wiegleb \& Herr 1983) still require clarification, possibly by using a genetic approach (Kaplan \& Štěpánek 2003, Bradley et al. 2011, Telford et al. 2011).

\section{Evolution and physiological characteristics of aquatic macrophytes}

The terrestrial higher plants evolved in the Ordovician period (c. 450 million years ago) from the Characeae being a family of complex structured Chlorophyta (green algae) with a stem and lateral branches (Bresinsky et al. 2008). The evolution of aquatic angiosperms probably emanated from terrestrial angiosperms involving processes of reduction and loss with regard to more complex ancestors (Arber 1920, Les et al. 1997). The adaptation of terrestrial plants to the life in the water is thought to have taken place independently many times, because despite the low proportion of higher plant species being macrophytic $(2 \%)$, this group is very heterogeneous, particularly with regard to reproduction strategies and growth forms, hinting at individual evolutionary lines (Philbrick \& Les 1996, Cook 1999). 
Submerged plants show a variety of adaptations to the life under water: leaves, shoots and rhizomes are typically rich in gas-filled lacunae causing buoyancy and facilitating oxygen and carbon dioxide transport within the plants (Sculthorpe 1967, Sand-Jensen \& Prahl 1982). Submerged leaves have only a thin cuticle with a water permeability about three times higher than that of surfaces from emergent leaves (Schönherr 1976), allowing effective nutrient uptake (Sand-Jensen et al. 1992). Early studies attributed anchoring in the sediment as the main function to the roots of hydrophytes (Brown 1913, Sutcliffe 1962), but their roots also play a significant role in nutrient uptake (Denny 1972, Chambers et al. 1989). Defense strategies of macrophytes include the translocation of nutrients and shortening of the growth period as observed for Potamogeton perfoliatus under grazing pressure (Miler \& Straile 2010). For Stratiotes aloides the allelopathic inhibition of algal growth has been observed (Mulderij et al. 2005) and Elodea nuttallii is capable of performing chemical defense against herbivorous insects (Erhard et al. 2007).

Aquatic plants except for bryophytes have the ability to use carbon not only from carbon dioxide, of which the uptake is a diffusive process, but also from bicarbonate being actively transported through the cell membrane (Madsen 1993). Depending on the $\mathrm{pH}$ of the water, inorganic carbon is predominantly present in the form of carbon dioxide (at $0{ }^{\circ} \mathrm{C}: \mathrm{pH}<6.5$ ), bicarbonate $(\mathrm{pH} 6.5-10)$ or carbonate $(\mathrm{pH}>10)$ (Gessner 1959). Another specific feature, though only of a few macrophyte species, is the capability to perform Crassulacean acid metabolism (CAM) being a photosynthesis mechanism involving nighttime fixation of carbon in the form of malate acid for decarboxylation at daytime. The CAM occurs in terrestrial plants adapted to aridity and in aquatic plants, like Isoëtes lacustris or Litorella uniflora, adapted to carbon limitation (Keeley 1998).

\section{Ecological functions of river macrophytes}

Macrophytes increase the diversity of ecological niches by providing hiding place, feeding habitat and spawning ground or serving as food for fish (Petr 2000, Valley et al. 2004), invertebrates (Berg 1949, Rooke 1986, Brusven et al. 1990, Newman 1991) and waterfowl (Søndergaard et al.1998). An example for an indirect positive effect of aquatic rhizophytes in running waters for animals depending on the hyporheic interstitial - like the brown trout being the host fish of the freshwater perl mussel - is the reduction of the load of fine particles in the water column. Due to erosion, caused for example by hydraulic engineering or coming from agricultural land, high amounts of suspended matter can regularly be found in lowland rivers, silting the interstitial (Altmüller \& Dettmer 1996). As macrophytes reduce the current velocity within the vegetation patches, they cause sedimentation and act as "sand filters" (SandJensen 1998). They also prevent erosion from the banks by fixing the sediment with their roots. Macrophytes contribute to the "self-purification" of water bodies directly by uptake of 
nutrients and oxygenation of the water and the sediment, but also indirectly by building the substrate for epiphytic algae that multiply the same effects (Engelhardt \& Ritchie 2001, Dhote \& Dixit 2009).

\section{Practical applications of aquatic macrophytes}

An application of aquatic macrophytes is the use as bioindicators. Although the knowledge about the aut- and synecological tolerance ranges of macrophyte species or communities against specific factors is still insufficient (Lansdown \& Bosanquet 2010), the sensitiveness of macrophytes to changes in environmental conditions as for example eutrophication and pollution has been verified by means of field (Kohler et al. 1974, Kutscher 1984, O'Hare et al. 2010) and experimental studies (Grube 1975, Glänzer et al. 1977, Geurts et al. 2009). In the European Water Framework Directive (European Union 2000) macrophytes are used as one of five biological components for the assessment of the ecological quality of water bodies.

Other applications of macrophytes include the use of fast growing macrophytes like Lemna minor, Spirodela polyrhiza or Salvinia minima for phytoremediation purposes like organic wastewater treatment (Bergmann et al. 2000, Körner et al. 2003, Olguín et al. 2007). The gained protein-rich phytomass can be harvested and used as animal food or for the production of fuel ethanol (Culley \& Epps 1973, Cheng \& Stomp 2009). Lemna minor is also frequently used to test chemicals for environmental toxicity in a standard test (International Organization for Standardization 2005).

Threats to the phytodiversity in running waters: eutrophication and alterations of the morphology of water courses

The vegetation of western European streams and rivers, consisting of c. 100 macrophyte species (Haslam 1987), has largely been affected by eutrophication and construction measures during the second half of the twentieth century (Riis \& Sand-Jensen 2001, Ellenberg \& Leuschner 2010). Eutrophication, the increase in productivity of a water body caused by the addition of nutrients, may be a slow natural process, but occurs as man-made phenomenon especially in industrialized countries due to regular fertilizer or sewage inflow with the surface water (Lampert \& Sommer 1993). On German farmland, phosphorus fertilization has dropped after a peak in the 1970s, while the nitrogen input by fertilization is still about four times higher today than in the 1950s (Figure 1.1). The negative effect of eutrophication on macrophytes is mostly an indirect one, in the way that phytoplankton and epiphytic algae get to a mass reproduction shading out submerged, rooted plants (Phillips et al. 1978). In few cases of macrophyte decline, direct ammonium toxicity has been diagnosed (Smolders et al. 1996, Zantout et al. 2011). In Germany, especially in the lowlands, in the 
course of melioration the majority of the streams and rivers has considerably been modified in their morphological structure (Umweltbundesamt 2011). Alterations of the morphology of water courses by construction works mostly result in degraded habitats for macrophytes, due to increased water turbidity from erosion and a loss of sheltered inlets, backwaters and transition zones to floodplain areas (Lubke et al. 1984, Baattrup-Pedersen \& Riis 1999).

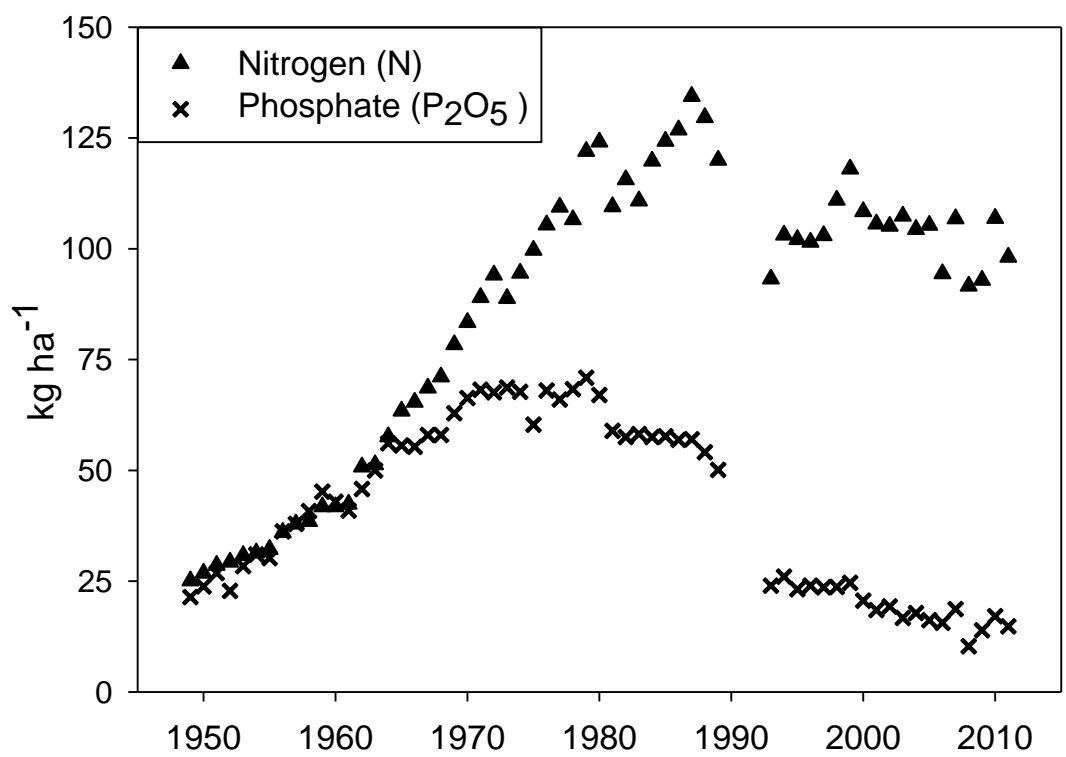

Figure 1.1 Nutrient inputs by fertilization on German farmland between 1949 and 2011, based on data taken from Statistisches Bundesamt (2012)

\section{Thesis aim and chapter outline}

At the beginning of this $\mathrm{PhD}$ thesis stood the idea that the potential of aquatic plants as long-term indicators for environmental conditions was not yet extendedly explored and applied in Central European running waters. The aim of this study is to draw a multi-faceted picture of the macrophyte vegetation of streams and rivers as related to habitat characteristics and its temporal development over 60 years using the example of the northwest German lowlands.

Chapter 1 presents the background and the concept of the study, giving an overview of the state of knowledge about the vegetation of running waters and information on the natural conditions and anthropogenic influences in the study area.

In chapter 2 correlations between the environmental conditions of running waters and the macrophyte occurrences recorded in 289 sites in 2010/2011 are presented. Relevant environmental factors (among those measured are $\mathrm{pH}$ and nutrient contents of the water and the sediment, river size and flow velocity) being decisive for the current vegetation composition were to be identified testing on the species and community levels.

In chapter 3 the floristic compositions of 338 vegetation relevés from the 1950s and the same number of relevés from 2010/2011 are compared, asking whether changes in the 
species richness and diversity have occurred over the six decades. Species traits like leaf longevity and specific leaf area (SLA) were included in the comparison, as a relation with environmental conditions is assumed, as well as environmental variables like current velocity and the Ellenberg indicator value for nitrogen, to extend the basis for identifying causes of observed changes. For a subset of the data (29.6\% of the study sites) a three-step comparison between the 1950s, the 1980s and 2010 allowed the analysis of the time course of the species richness and diversity development.

For chapter 4 the macrophyte assemblages from the 1950s and from 2010/2011 were classified in order to detect changes in the macrophyte community structure over the six decades. Assuming that two independent classification systems should lead to more robust conclusions on vegetation change than one system alone, two different phytosociological character species-based systems were applied. Community development was analyzed on the landscape and cross-regional scale, also in relation to the change in habitat characteristics.

In chapter 5 the synthesis of the three parts of the study as presented in the chapters 2 to 4 is given, combining the knowledge about the habitat preferences of the different macrophyte species and communities and about the floristic and syntaxonomic developments over six decades. Methodological aspects of assessing long-term change in macrophyte communities are pointed out, the probable causes of the vegetation change in running waters are outlined and possible future developments discussed.

\section{The study area: geology, climate and human influence}

The federal states Lower Saxony, Schleswig-Holstein and the northern part of North Rhine-Westphalia make up the north-west German lowlands being a morphologically diverse Pleistocene landscape, bordered by the Northern Sea, Denmark and the Baltic Sea in the north, the Netherlands in the west, Mecklenburg-Vorpommern, Brandenburg and SaxonyAnhalt in the east and the Central German highlands in the south. Glacial processes formed the relief until the end of the last (Weichsel) Ice Age 10,000 years ago and since about 1,000 years anthropogenic colonization influences the shape of the landscape surface (Liedtke \& Marcinek 2002). Melioration measures improving the agricultural land use are conducted since the Middle Ages. In terms of the Köppen-Geiger climate classification, the north German lowlands belong to the warm, temperate and year-round humid zone (Kottek et al. 2006). The coastal regions (Schleswig-Holstein and the north-western parts of Lower Saxony) are characterized by an Atlantic climate with low temperature amplitudes (c. $1.3^{\circ} \mathrm{C}$ in the winter and c. $15.9^{\circ} \mathrm{C}$ in the summer, Kiel) and relatively high precipitation amounts (c. $754 \mathrm{~mm} \mathrm{yr}^{-1}$, Kiel), whereas the south-eastern parts of the study area (the northern Harz foothills and base of the Weser-Leine uplands) have a continental climate with higher 
temperature amplitudes (c. $1.0^{\circ} \mathrm{C}$ in the winter and c. $16.6^{\circ} \mathrm{C}$ in the summer, Braunschweig) and lower precipitation amounts (c. $656 \mathrm{~mm} \mathrm{yr}^{-1}$, Hannover) (means over thirty years, Deutscher Wetterdienst 2013).

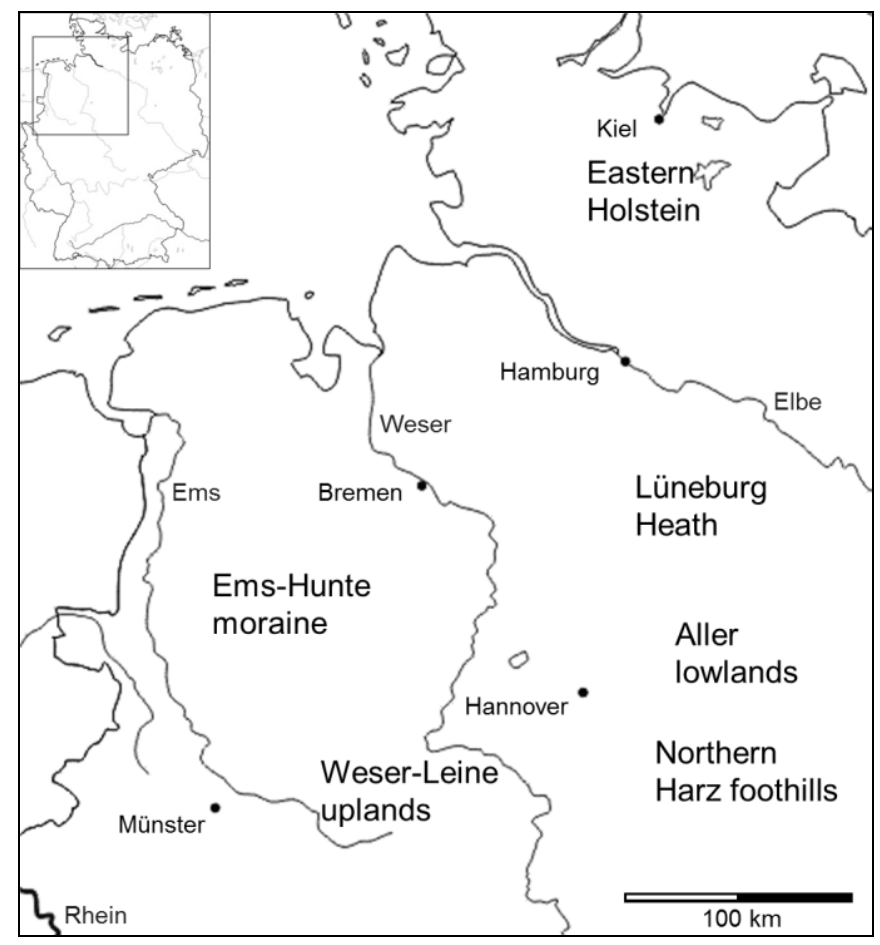

Figure 1.2 Location of the study regions within the north-west German lowlands: the Ems-Hunte moraine country (78 plots), the Lüneburg Heath and Aller lowlands (108 plots), the northern Harz foothills and base of the Weser-Leine uplands (91 plots) and the eastern Holstein moraine country (61 plots)

Table 1.1 Number of studied rivers and semi-permanent plots per study region, mean widths and depths of the studied river reaches in the 1950s and in 2010/2011 (means \pm SD) and most intensively sampled rivers

\begin{tabular}{|c|c|c|c|c|c|c|c|}
\hline Region & $\begin{array}{l}\text { No. } \\
\text { of ri- } \\
\text { vers }\end{array}$ & $\begin{array}{l}\text { No. } \\
\text { of } \\
\text { plots }\end{array}$ & $\begin{array}{l}\text { Reach } \\
\text { width } \\
1950 \mathrm{~s} \\
{[\mathrm{~m}]} \\
\end{array}$ & $\begin{array}{l}\text { Reach } \\
\text { width } \\
2010 / 11 \\
{[\mathrm{~m}]} \\
\end{array}$ & $\begin{array}{l}\text { Reach } \\
\text { depth } \\
1950 \mathrm{~s} \\
{[\mathrm{~m}]} \\
\end{array}$ & $\begin{array}{l}\text { Reach } \\
\text { depth } \\
2010 / 11 \\
{[\mathrm{~m}]} \\
\end{array}$ & $\begin{array}{l}\text { Most } \\
\text { intensively } \\
\text { sampled rivers } \\
\text { (no. of plots) }\end{array}$ \\
\hline $\begin{array}{l}\text { Ems-Hunte } \\
\text { moraine }\end{array}$ & 21 & 78 & $7.7 \pm 4.4$ & $12.6 \pm 12.9$ & $0.9 \pm 0.5$ & $1.4 \pm 0.7$ & $\begin{array}{l}\text { Hunte (32), } \\
\text { Elze (6) }\end{array}$ \\
\hline $\begin{array}{l}\text { Lüneburg Heath } \\
\text { with Aller } \\
\text { lowlands }\end{array}$ & 24 & 108 & $9.9 \pm 7.8$ & $9.7 \pm 7.5$ & $0.8 \pm 0.5$ & $0.8 \pm 0.6$ & $\begin{array}{l}\text { Lachte (16), } \\
\text { Aller (15), } \\
\text { Örtze (15) }\end{array}$ \\
\hline $\begin{array}{l}\text { Harz foothills with } \\
\text { base of Weser- } \\
\text { Leine uplands }\end{array}$ & 19 & 91 & $9.4 \pm 7.8$ & $9.6 \pm 7.4$ & $0.8 \pm 0.7$ & $0.9 \pm 0.7$ & $\begin{array}{l}\text { Schunter (29), } \\
\text { Oker (27) }\end{array}$ \\
\hline Eastern Holstein & 6 & 61 & $3.9 \pm 3.3$ & $8.7 \pm 7.4$ & $0.8 \pm 0.5$ & $1.2 \pm 0.6$ & $\begin{array}{l}\text { Kossau (31), } \\
\text { Schwentine (12) }\end{array}$ \\
\hline
\end{tabular}


Seventy streams and rivers were studied, belonging to the catchments of the Rhine, the Ems, the Weser and the Elbe flowing into the Northern Sea, or draining to the Baltic Sea. They are located in six regions (Figure 1.2). The Ems-Hunte moraine country (15-50 m a.s.I.), located between the rivers Ems and Weser, is characterized by base-poor, sandy and sometimes loamy soils originating from the penultimate (Saale) Ice Age (Meynen \& Schmithüsen 1962). Especially in the south around the c. $12 \mathrm{~km}^{2}$ big Dümmer lake, rests of fens and bogs are distributed, which had once been dominant in this region before having widely been drained for land cultivation during the last centuries (Finck et al. 1997). Today, an intensive agricultural management predominates. Settlements and forests account for an area below the national average, while the area of agriculturally used land (67-73\%) is above the national average of $55 \%$ and the proportion of this land being used for crop cultivation has risen between the 1950s (34-48\%), when wet meadows used for cattle grazing were still common, and 1991 (63-78\%), due to an improvement of the drainage techniques (Finck et al. 1997).

The Lüneburg Heath (30-60 $\mathrm{m}$ a.s.l.), lying between the rivers Elbe and Aller, is characterized by nutrient-poor, acid sand soils (Meynen \& Schmithüsen 1962). About 2,000$3,000 \mathrm{BC}$ the first settlers started cutting trees and establishing a heathland agriculture that reached a peak in the eighteenth century with c. $75 \%$ of the Lüneburg Heath area being heathland (Finck et al. 1997). Since then reforesting, mainly with managed pine and spruce forests, occurred that decreased the proportion of heathland to c. $20 \%$ of the area of this region, where intensive crop cultivation also plays a role since the 1950s (Finck et al. 1997). Remarkably, in the Lüneburg Heath structurally unmodified streams and rivers can still be found (Niedersächsisches Landesamt für Ökologie 2001). The Aller lowlands (30-60 m a.s.I.), located between the Lüneburg Heath in the north and the northern Harz foothills in the south, are characterized by base-poor sand soils and alluvial deposits (Meynen \& Schmithüsen 1962). Forests are underrepresented in this region, while settlements and agricultural land represent the national average; the predominant land-use type is crop cultivation (Finck et al. 1997). In the chapters 3 and 4, the sites in the Aller lowlands were included in the Lüneburg Heath region, due to resembling bedrock chemistries.

The northern Harz foothills (45-160 m a.s.l.), located in a zone with Pleistocene loess deposits at the base of the Central highlands, are characterized by relatively base- and nutrient-rich sandy or loamy soils (Meynen \& Schmithüsen 1962). This region has a long dating back tradition of crop cultivation; forests are mainly restricted to the hill tops and most of the rivers were subject to hydro-engineering and some were also affected by potash salt and coal mining (Finck et al. 1997). The base of the Weser-Leine uplands (90-210 m a.s.l.) is also located in the transition zone between the northern lowlands and the Central highlands, being characterized by base-rich soils (Meynen \& Schmithüsen 1962). In the chapters 3 and 
4 the sites at the base of the Weser Leine uplands were integrated in the northern Harz foothills region, because in all those sites runoff and groundwater are influenced by the silicate- or carbonate-rich bedrock of the uplands.

The eastern Holstein moraine country (25-40 m a.s.I.), located between the Baltic Sea and the Elbe valley, is characterized by relatively base- and nutrient-rich, sandy or loamy young moraine soils and littered with lakes originating from the Weichsel Ice Age (Meynen \& Schmithüsen 1962). The proportion of forested area is low and intensive crop cultivation is the predominant land-use type (Finck et al. 1997).

The streams and rivers have sandy sediments, which are partly overlain by gravel especially in the Lüneburg Heath and northern Harz foothills regions, where summer-cool, rhithral water courses can be found. In the potamal rivers of the Ems-Hunte and eastern Holstein moraine regions, sapropels and organic deposits are not uncommon. Modifications to the hydromorphology of the investigated water courses between the 1950s and 2010/2011 were most pronounced in the Ems-Hunte moraine and eastern Holstein regions, whereas only slight widening and deepening occurred in the Lüneburg Heath and northern Harz foothills regions (Table 1.1).

\section{Nomenclature}

The nomenclature of the species follows Buttler \& Thieme (2011) for vascular plants and Koperski et al. (2000) for bryophytes. Syntaxonomic vegetation units are named after Preising et al. (1990), Chytrý (2011), or if bryophyte-dominated after Schubert (2008). 


\section{References}

Altmüller, R. \& R. Dettmer (1996): Unnatürliche Sandfracht in Geestbächen - Ursachen, Probleme und Ansätze für Lösungsmöglichkeiten - am Beispiel der Lutter. Informationsdienst Naturschutz Niedersachsen 16(5): 222-237.

Arber, A. (1920): Water plants - a study of aquatic angiosperms. Cambridge University Press, Cambridge: $436 \mathrm{p}$.

Baattrup-Pedersen, A. \& T. Riis (1999): Macrophyte diversity and composition in relation to substratum characteristics in regulated and unregulated Danish streams. Freshwater Biology 42(2), 375-385.

Bard, J. (1965): Végétaux aquatiques tropicaux. Bois et Forêts des Tropiques 99: 3-11.

Bennett, F.D. (1967): Notes on the possibility of biological control of the water-hyacinth Eichhornia crassipes. International Journal of Pest Management, part C, 13(4): 304309.

Berg, C.O. (1949): Limnological relations of insects to plants of the genus Potamogeton. Transactions of the American Microscopical Society 68(4): 279-291.

Bergmann, B.A., J.J. Cheng, J. Classen \& A.M. Stomp (2000): Nutrient removal from swine lagoon effluent by duckweed. Transactions of the American Society of Agricultural Engineers 43: 263-269.

Bradley, C., S.J. Preston, J. Provan \& N. Reid (2011): Current status and conservation genetics of the river water-crowfoot Ranunculus fluitans. Northern Ireland Environment Agency Research and Development Series 11/08: $13 \mathrm{p}$.

Bresinsky, A., C. Körner, J.W. Kadereit, G. Neuhaus \& U. Sonnewald (2008): Strasburger Lehrbuch der Botanik. Spektrum, Heidelberg: 1175 p.

Brown, W.H. (1913): The relation of the substratum to the growth of Elodea. The Philippine Journal of Science 8: 1-20.

Brusven, M.A., W.R. Meehan \& R.C. Biggam (1990): The role of aquatic moss on community composition and drift of fish-food organisms. Hydrobiologia 196: 39-50.

Butcher, R.W. (1927): A preliminary account of the vegetation of the river Itchen. Journal of Ecology 15: 55-65

Buttler, K.P. \& M. Thieme (2011): Florenliste von Deutschland - Gefäßpflanzen, Version 3. Frankfurt a.M., http://www.kp-buttler.de [20.04.2013]

Chambers, P.A., E.E. Prepas, M.L. Bothwell \& H.R. Hamilton (1989): Roots versus shoots in nutrient uptake by aquatic macrophytes in flowing waters. Canadian Journal of Fisheries and Aquatic Sciences 46(3): 435-439.

Chambers, P.A., P. Lacoul, K.J. Murphy \& S.M. Thomaz (2008): Global diversity of aquatic macrophytes in freshwater. Hydrobiologia 595(1): 9-26.

Cheng, J.J. \& A.M. Stomp (2009): Growing duckweed to recover nutrients from wastewaters and for production of fuel ethanol and animal feed. Clean Soil, Air, Water 37(1): 1726.

Chytrý, M. (2011): Vegetace České republiky 3. Vodní a mokřadní vegetace [Vegetation of the Czech Republic 3. Aquatic and wetland vegetation]. Academia, Prague: 827 p.

Cook, C.D.K. (1966): A monographic study of Ranunculus subgenus Batrachium (DC.) A. Gray. Mitteilungen der Botanischen Staatssammlung München 6: 47-237.

Cook, C.D.K. (1968): The vegetation of the Kainji reservoir site in northern Nigeria. Plant Ecology: 15(4): 225-243.

Cook, C.D.K. (1999): The number and kinds of embryo-bearing plants which have become aquatic: a survey. Perspectives in Plant Ecology, Evolution and Systematics 2(1): 79_ 102. 
Culley D.D. \& E.A. Epps (1973): Use of duckweed for waste treatment and animal feed. Journal of the Water Pollution Control Federation 45(2): 337-347.

Den Hartog, C. \& S. Segal (1964): A new classification of the water-plant communities. Acta Botanica Neerlandica 13: 367-393.

Denny, P. (1972): Sites of Nutrient Absorption in Aquatic Macrophytes. Journal of Ecology 60(3): 819-829.

Dersch, G. (1987): Zur Verbreitung der Callitriche-Arten (Wassersterne) in Niedersachsen. Göttinger Floristische Rundbriefe 20: 70-100.

Dhote, S. \& S. Dixit (2009): Water quality improvement through macrophytes - a review. Environmental Monitoring and Assessment 152(1-4): 149-153.

Deutscher Wetterdienst (2013):

http://www.dwd.de/bvbw/appmanager/bvbw/dwdwwwDesktop?_nfpb=true\&_pageLab el=_dwdwww_klima_umwelt_klimadaten_deutschland\&T82002gsbDocumentPath=N avigation\%2FOeffentlichkeit\%2FKlima_Umwelt\%2FKlimadaten\%2Fkldaten_kosten frei\%2Fkldat_D__mittelwerte_node.html\%3F_nnn\%3Dtrue [21.04.2013]

Ellenberg, H. \& C. Leuschner (2010): Vegetation Mitteleuropas mit den Alpen. Ulmer, Stuttgart: $1334 \mathrm{p}$.

Engelhardt, K.A. \& M.E. Ritchie (2001): Effects of macrophyte species richness on wetland ecosystem functioning and services. Nature 411(6838): 687-689.

Erhard, D., G. Pohnert \& E.M. Gross (2007): Chemical defense in Elodea nuttallii reduces feeding and growth of aquatic herbivorous Lepidoptera. Journal of Chemical Ecology 33: $1646-1661$.

European Union (2000): Directive 2000/60/EC of the European Parliament and of the Council of 23 October 2000 establishing a framework for Community action in the field of water policy. Official Journal of the European Communities L 327: 1-72.

Finck, P., U. Hauke, E. Schröder, R. Forst \& G. Woithe (1997): Naturschutzfachliche Landschafts-Leitbilder: Rahmenvorstellungen für das Nordwestdeutsche Tiefland aus bundesweiter Sicht. Schriftenreihe für Landschaftspflege und Naturschutz 50/1: 1265.

Forel, F.A. (1901): Handbuch der Seenkunde - allgemeine Limnologie. Engelhorn, Stuttgart: $249 \mathrm{~S}$.

Gessner, F. (1959): Hydrobotanik, die physiologischen Grundlagen der Pflanzenverbreitung im Wasser, Bd. 2: Stoffhaushalt. VEB Deutscher Verlag der Wissenschaften, Berlin: $701 \mathrm{~S}$.

Geurts, J.J., J.M. Sarneel, B.J. Willers, J.G. Roelofs, J.T. Verhoeven \& L.P. Lamers (2009): Interacting effects of sulphate pollution, sulphide toxicity and eutrophication on vegetation development in fens: a mesocosm experiment. Environmental Pollution 157(7): 2072-2081.

Glänzer, U., W. Haber \& A. Kohler (1977): Experimentelle Untersuchungen zur Belastbarkeit submerser Fließgewässer-Makrophyten. Archiv für Hydrobiologie 79(2): 193-232.

Glück, H. (1924): Biologische und morphologische Untersuchungen über Wasser- und Sumpfgewächse IV, Jena: 1-746.

Grube, H.-J. (1975): Die Makrophytenvegetation der Fließgewässer in Süd-Niedersachsen und ihre Beziehungen zur Gewässerverschmutzung. Dissertation, Göttingen: 456 p.

Haslam, S.M. (1987): River plants of western Europe: the macrophytic vegetation of watercourses of the European Economic Community. Cambridge University Press, Cambridge: $517 \mathrm{p}$. 
Horvatić, S. (1931): Die verbreitetsten Pflanzengesellschaften der Wasser- und Ufervegetation in Kroatien und Slavonien. Acta botanica Instituti Botanici Universitatis Zagrebensis 6: 91-108.

International Organization for Standardization (2005): ISO 20079: Water quality determination of the toxic effect of water constituents and waste water on duckweed (Lemna minor) duckweed growth inhibition test. ISO TC 147/SC 5/WG 5: 26 p.

Jones, H. (1955): Studies on the ecology of the river Rheidol I. Plant colonization and permanent quadrat records in the main stream of the lower Rheidol. Journal of Ecology 43(2): 462-476.

Kaplan, Z. \& J. Štěpánek (2003): Genetic variation within and between populations of Potamogeton pusillus agg. Plant Systematics and Evolution 239(1-2): 95-112.

Keeley, J. (1998): CAM photosynthesis in submerged aquatic plants. The Botanical Review 64: 121-175.

Koch, W. (1926): Die Vegetationseinheiten der Linthebene unter Berücksichtigung der Verhältnisse in der Nordostschweiz - systematisch-kritische Studie. Dissertation, Eidgenössisch Technische Hochschule Zürich: 144 p.

Kohler, A., R. Brinkmeier \& H. Vollrath (1974): Verbreitung und Indikatorwert der submersen Makrophyten in den Fließgewässern der Friedberger Au. Berichte der Bayerischen Botanischen Gesellschaft 45: 5-36.

Koperski, M., M. Sauer, W. Braun \& S.R. Gradstein (2000): Referenzliste der Moose Deutschlands. Schriftenreihe für Vegetationskunde 34: 1-519.

Körner, S., J.E. Vermaat \& S. Veenstra (2003): The capacity of duckweed to treat wastewater. Journal of Environmental Quality 32(5): 1583-1590.

Kottek, M., J. Grieser, C. Beck, B. Rudolf \& F. Rubel (2006): World map of the KoppenGeiger climate classification updated. Meteorologische Zeitschrift 15(3): 259-264.

Kutscher, G. (1984): Verbreitung und Ökologie höherer Wasserpflanzen in Fließgewässern der Schwäbischen Alb - dargestellt an den Flüssen: Bära, Schmiecha, Lauchert, Zwiefalter Ach und Große Lauter. Dissertation, Technische Universität München: $289 \mathrm{p}$.

Kützing, F.T. (1832): Über die deutschen Callitrichen. Linnaea 7: 174-192.

Lampert, W \& U. Sommer (1993): Limnoökologie. Thieme, Stuttgart: 440 p.

Lansdown, R.V. (2006): Notes on the water-starworts (Callitriche) recorded in Europe. Watsonia 26: 105-120.

Lansdown, R. \& S. Bosanquet (2010): Riverine plants as biological indicators. In: Hurford, C., M. Schneider \& I. Cowx (edts): Conservation monitoring in freshwater habitats, Springer, Dordrecht: 73-83.

Lebrun, J. (1947): La végétation de la plaine alluviale au sud du lac Edouard. Exploration du Parc National Albert, Congo, mission J. Lebrun (1937-38), Bruxelles, Fascicule 1: 1800.

Les, D.H., E. Landolt \& D.J. Crawford (1997): Systematics of the Lemnaceae (duckweeds) inferences from micromolecular and morphological data. Plant Systematics and Evolution 204(3-4): 161-177.

Liedtke, H. \& J. Marcinek (2002): Physische Geographie Deutschlands. Klett-Perthes, Gotha: $786 \mathrm{p}$.

Lubke, R.A., P.E. Reavell \& P.J. Dye (1984): The effects of dredging on the macrophytic vegetation of the Boro River, Okavango Delta, Botswana. Biological conservation 30(3): 211-236. 
Luther, H. (1949): Vorschlag zu einer ökologischen Grundeinteilung der Hydrophyten. Acta Botanica Fennica 44: 1-15.

Madsen, T.V. (1993): Growth and photosynthetic acclimation by Ranunculus aquatilis L. in response to inorganic carbon availability. New Phytologist 125: 707-715.

Mäkirinta, U. (1978): Ein neues ökomorphologisches Lebensform-System der aquatischen Makrophyten. Phytocoenologica 4: 446-470.

Meynen, E. \& J. Schmithüsen (1962): Handbuch der naturräumlichen Gliederung Deutschlands. Part 1 and 2, Bonn: $1339 \mathrm{p}$.

Miler, O. \& D. Straile (2010): How to cope with a superior enemy? Plant defence strategies in response to annual herbivore outbreaks. Journal of Ecology 98: 900-907.

Moyle, J.B. (1945): Some chemical factors influencing the distribution of aquatic plants in Minnesota. American Midland Naturalist 34(2): 402-420.

Muenscher, W.C. (1931): Aquatic vegetation of the Oswegatchie and Black River watersheds. In: State of New York Conservation Department (ed.): A Biological Survey of the Oswegatchie and Black River Watersheds, Albany, USA: 199-221.

Mulderij, G., W.M. Mooij \& E. Van Donk (2005): Allelopathic growth inhibition and colony formation of the green alga Scenedesmus obliquus by the aquatic macrophyte Stratiotes aloides. Aquatic Ecology 39: 11-21.

Newman, R. M. (1991): Herbivory and detritivory on freshwater macrophytes by invertebrates: a review. Journal of the North American Benthological Society 10: 89114.

Niedersächsisches Landesamt für Ökologie (2001): Gewässergütebericht 2000. Oberirdische Gewässer 13: 1-40.

O'Hare, M.T., R.T. Clarke, M.J. Bowes, C. Cailes, P. Henville, N. Bissett, C. McGahey \& M. Neal (2010): Eutrophication impacts on a river macrophyte. Aquatic Botany 92: 173178.

Olguín, E.J., G. Sánchez-Galván \& T. Pérez-Pérez (2007): Assessment of the phytoremediation potential of Salvinia minima Baker compared to Spirodela polyrrhiza in high-strength organic wastewater. Water, Air and Soil Pollution 181(1-4): 135-147.

Palisot de Beauvois, A.M.F.J. (1816): Memoire sur les Lemna, ou lentilles d'eau, sur leur fructification et sur la germination de leurs graines. Journal de Physique de Chimie et d'Histoire naturelle 82: 101-115.

Petr, T. (2000): Interactions between fish and aquatic macrophytes in inland waters: a review. Food and Agriculture Organization Fisheries Technichal Paper 396: 1-185.

Philbrick, T. \& Les, D.H. (1996): Evolution of aquatic angiosperm reproductive systems. BioScience 46 (11): 813-826.

Phillips, G.L., D. Eminson \& B. Moss (1978): A mechanism to account for macrophyte decline in progressively eutrophicated freshwaters. Aquatic Botany 4: 103-126.

Preising, E., H.-C. Vahle, D. Brandes, H. Hofmeister, J. Tüxen \& H.E. Weber (1990): Die Pflanzengesellschaften Niedersachsens - Bestandsentwicklung, Gefährdung und Schutzprobleme: Wasser- und Sumpfpflanzengesellschaften des Süßwassers. Naturschutz und Landschaftspflege in Niedersachsen 20/8: 47-161.

Preston, C.D. (1995): Pondweeds of Great Britain and Ireland. Botanical Society of the British Isles Handbook 8: $350 \mathrm{p}$.

Pulteney, R. (1800): Observations on the economical use of the Ranunculus aquatilis, with introductory remarks on the acrimonious and poisonous quality of some of the English species of that genus. Philosophical Magazine 6(23): 210-215. 
Riis, T. \& K. Sand-Jensen (2001): Historical changes in species composition and richness accompanying perturbation and eutrophication of Danish lowland streams over 100 years. Freshwater Biology 46: 269-280.

Roll, H. (1939): Die Pflanzengesellschaften ostholsteinischer Fließgewässer - Limnologischsoziologische Studien. Archiv für Hydrobiologie 34: 159-305.

Rooke, B. (1986): Macroinvertebrates associated with macrophytes and plastic imitations in the Eramosa River, Ontario, Canada. Archiv für Hydrobiologie 106: 307-325.

Sand-Jensen, K. (1998): Influence of submerged macrophytes on sediment composition and near-bed flow in lowland streams. Freshwater Biology 39(4): 663-679.

Sand-Jensen, K. \& C. Prahl (1982): Oxygen exchange with the lacunae and across leaves and roots of the submerged vascular macrophyte Lobelia dortmanna L. New Phytologist 91: 103-120.

Sand-Jensen, K., M.F. Pedersen \& S.L. Nielsen (1992): Photosynthetic use of inorganic carbon among primary and secondary water plants in streams. Freshwater Biology 27(2): 283-293.

Sauvageau, C. (1891): Sur les feuilles de quelques monocotylédones aquatiques. Dissertation, Paris: $200 \mathrm{p}$.

Schönherr, J. (1976): Water permeability of isolated cuticular membranes: the effect of cuticular waxes on diffusion of water. Planta 131(2): 159-164.

Schotsman, H.D. (1967): Les Callitriches espèces de France et taxa noveaux d'Europe. Paris: $152 \mathrm{p}$.

Schubert, R. (2008): Die Moosgesellschaften des Nationalparks Harz. Mitteilungen zur floristischen Kartierung Sachsen-Anhalt, Sonderheft 5: $81 \mathrm{p}$.

Schwoerbel, J. (1993): Einführung in die Limnologie. Fischer, Stuttgart: 387 S.

Sculthorpe, C.D. (1967): The biology of aquatic vascular plants. Edward Arnold Publishers, London: $610 \mathrm{p}$.

Smolders, A.J.P., C. Den Hartog, C.B.L. Van Gestel \& J.G.M. Roelofs (1996): The effects of ammonium on growth, accumulation of free amino acids and nutritional status of young phosphorus deficient Stratiotes aloides plants. Aquatic Botany 53(1): 85-96.

Søndergaard, M., T.L. Lauridsen, E. Jeppesen \& L. Bruun (1998): Macrophyte-waterfowl interactions: tracking a variable resource and the impact of herbivory on plant growth. Ecological Studies 131: 298-306.

Statistisches Bundesamt (2012): Produzierendes Gewerbe, Düngemittelversorgung, Wirtschaftsjahr 2011/2012. Fachserie 4, Reihe 8.2. Wiesbaden: 36 p.

Steusloff, U. (1939): Zusammenhänge zwischen Boden, Chemismus des Wassers und Phanerogamenflora in fliessenden Gewässern der Lüneburger Heide um Celle und Uelzen (nebst Untersuchungen über die Perlmuschel in diesen Gewässern). Archiv für Hydrobiologie 35: 70-106.

Sutcliffe, J.F. (1962): Mineral salts absorption in plants. Pergamon Press, London: 204 p.

Tansley, A.G. (1911): Types of British vegetation. University Press, Cambridge: 416 p.

Telford, A., M.T. O'Hare, S. Cavers \& N. Holmes (2011): Can genetic bar-coding be used to identify aquatic Ranunculus L. subgenus Batrachium (DC) A. Gray? A test using some species from the British Isles. Aquatic Botany 95(1): 65-70.

Thomson, J.W. (1944): A survey of the larger aquatic plants and bank flora of the Brule River. Transactions of the Wisconsin Academy of Sciences, Arts and Letters 36: 5776.

Tuckerman, E. (1849): Observations on American Species of the Genus Potamogeton L. American Journal of Science and Arts 2(7): 347-360. 
Umweltbundesamt (2011): Daten zur Umwelt - Ausgabe 2011 - Umwelt und Landwirtschaft. Umweltbundesamt, Dessau-Roßlau: $98 \mathrm{p}$.

Valley, D., T.K. Cross, P. Radomski (2004): The role of submersed aquatic vegetation as habitat for fish in Minnesota lakes, including the implications of non-native plant invasions and their management. Minnesota Department of Natural Resources Special Publication 160: 1-25.

Weintroub, D. (1933): A preliminary account of the aquatic and sub-aquatic vegetation and flora of the Witwatersrand. The Journal of Ecology 21: 44-57.

Wiegleb, G. \& Herr, W. (1983): Taxonomie und Verbreitung von Ranunculus Subgenus Batrachium in niedersächsischen Fließgewässern unter besonderer Berücksichtigung des Ranunculus penicillatus-Komplexes. Göttinger Floristische Rundbriefe 17: 101150.

Wiegleb, G. \& Kaplan, Z. (1998): An account of the species of Potamogeton L. (Potamogetonaceae). Folia Geobotanica 33: 241-316.

Zantout, N., P. Wilfert, A.J.P. Smolders, G. Weber \& D. Zacharias (2011): Effects of sediment pore water qualities on the decline of Stratiotes aloides L. stands in Bremen, Germany. Fundamental and Applied Limnology 179(2): 131-136. 


\section{Chapter 2}

Relationships between macrophyte vegetation and physical and chemical conditions in north-west German running waters

Kristina Steffen, Christoph Leuschner, Uta Müller, Gerhard Wiegleb \& Thomas Becker

(Aquatic Botany, in press)
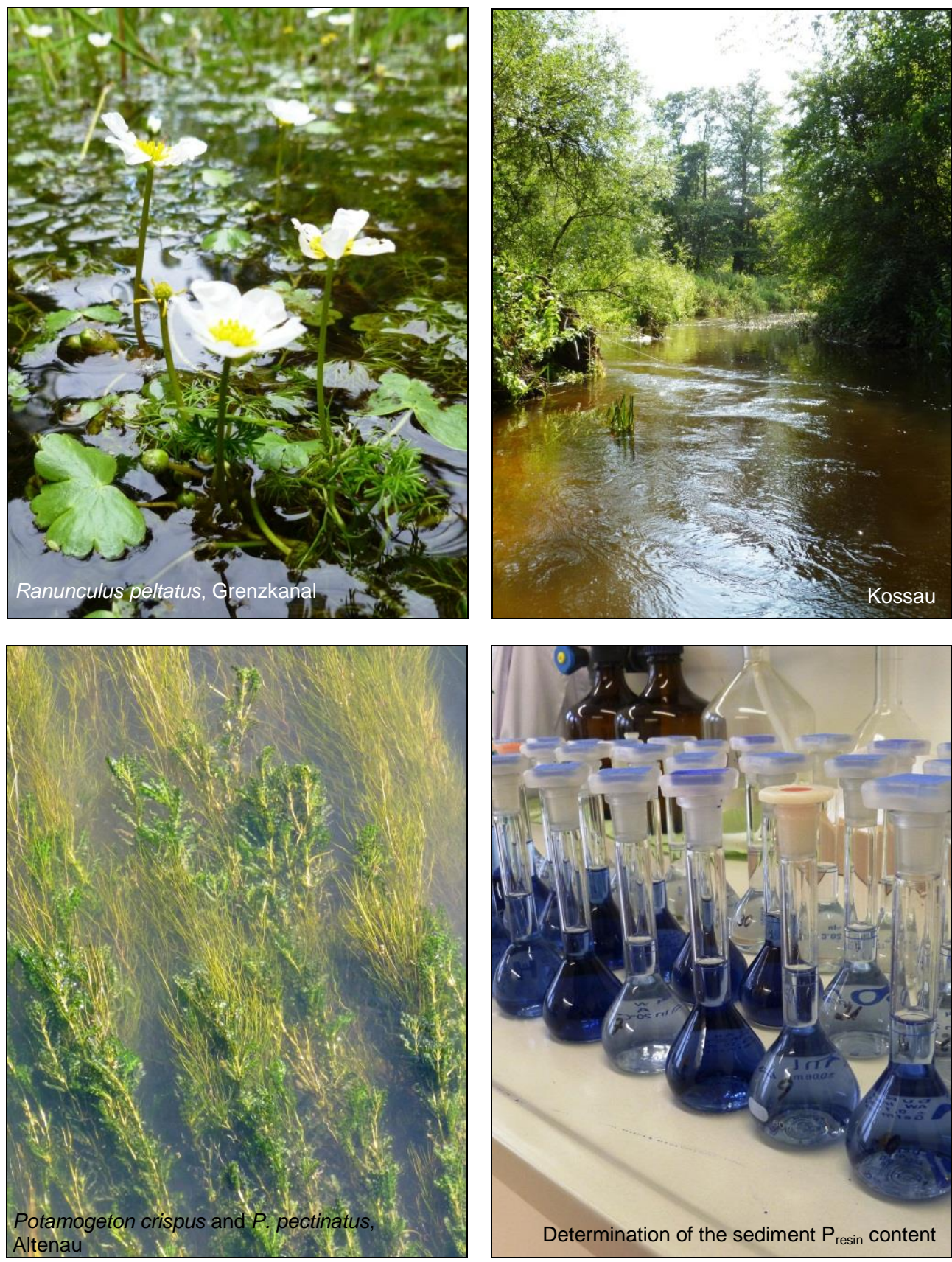


\section{Abstract}

The macrophyte vegetation of Central Europe's rivers and streams has markedly impoverished during the last decades as a consequence of man's impact on water chemistry and hydromorphology. Here, we examine relationships between species composition and about 35 physical, chemical and river morphological parameters in 69 water courses (291 sampling plots) in the Pleistocene lowlands of north-west Germany for identifying indicator species and environmental parameters suited for categorizing habitat types, growing conditions and the anthropogenic influence in these profoundly altered aquatic ecosystems. Of the 94 species recorded in total, 31 frequent taxa were analyzed for their affinity to specific environmental conditions. Current velocity and water depth (river size) were the most influential determinants of community composition while chemical factors were of secondary importance. We identified eight macrophyte assemblages, each with their own distinctive indicator species and characteristic combinations of growth forms. Small rhithral, relatively nutrient-poor water courses with high velocity were indicated by Myriophyllum alterniflorum and Ranunculus peltatus, while Elodea nuttallii, Myriophyllum spicatum and Spirodela polyrhiza characterized large, potamal water courses with high trophy. We conclude that macrophytes may serve as valuable bioindicators of habitat conditions even in anthropogenically altered running waters, but the specific effects of physical, chemical, and river morphological factors are difficult to separate.

Keywords: bioindication, current velocity, macrophyte assemblages, sediment characteristics, water chemistry

\section{Introduction}

There is general consensus that the distribution patterns of freshwater macrophytes in flowing waters are largely determined by a few physical and chemical factors including current velocity (Janauer et al. 2010, Grinberga 2011), the grain size and nutrient content of the bottom substrate (Baattrup-Pedersen and Riis 1999, Paal et al. 2007), the trophic state of the water body (Demars and Harper 1998) and the geochemistry of the catchment (Grasmück et al. 1995, Barendregt and Bio 2003, Baattrup-Pedersen et al. 2008). Even though current velocity was identified already eighty years ago as a decisive factor determining the vegetation structures in running waters (Butcher 1933), in the subsequent decades, most Central European studies on the ecology of river macrophyte vegetation focused on hydrochemistry. The principal objective was to establish a macrophyte-based indicator system for water pollution assessment, comparable to the standardized Central European macrozoobenthos-based saprobic system (Grube 1975, Weber 1976, Kohler 
1978, Wiegleb 1979, Janauer 1981). These investigations revealed, however, that the influence of physical factors, notably current velocity, seems to overlay the effects of sediment and water chemistry on community composition in many cases, causing a more or less distinct downstream zonation of vegetation. In contrast, chemical factors were found to differentiate only within the vegetation zones defined by the gradient of current velocity (Wiegleb 1984, Bernez et al. 2004, Daniel et al. 2006). Macrophyte indices for the assessment of the trophic status of rivers have been developed in the United Kingdom (MTR = Mean Trophic Rank, Holmes et al. 1999), Germany (TIM = Trophic Index of Macrophytes, Schneider and Melzer 2003) and France (IBMR = Macrophyte Biological Index for Rivers, Haury et al. 2006). Despite regional differences in the list of indicator species, the transnational validity of macrophyte indices has partly been confirmed (Schneider 2007). Nevertheless, the applicability of these indicators may be limited allowing only very rough assessments of environmental conditions, and the limitations are subject to ongoing discussion (e.g. Demars et al. 2012).

Recently, macrophyte studies in rivers have been triggered by the implementation of the European Water Framework Directive (WFD, European Union 2000) that brought the socalled 'good ecological condition' to the centre of attention. Integrative indicators are needed that are responsive to both physical and chemical factors and give information about the state of river bed morphology and the intensity of anthropogenic pressure. Macrophytes might be good indicator organisms, because in their growth and distribution they respond to all of these factors (Meilinger 2003, Schaumburg 2004, Kuhar et al. 2011). However, pronounced changes in Central Europe's macrophyte vegetation in the last 50 years (Riis and Sand-Jensen 2001, Ellenberg and Leuschner 2010, Steffen et al. 2013) make it necessary to re-evaluate the indicator value of macrophyte species and assemblages. Even though some attempts to differentiate between macrophyte assemblages hinted at the existence of only loose associations (Gessner 1955, Brux et al. 1988), a number of characteristic assemblages can be identified in Central European rivers (e.g. Weber-Oldecop 1969, Herr et al. 1990, Holmes et al. 1998, Paal and Trei 2004). Notwithstanding that the major drivers of vegetation distribution in rivers are largely known, we go a step further and try to assess the relative importance of hydromorphological, physical and chemical factors as possible controls of macrophyte occurrence.

We present the results of a study in 291 plots covering 69 rivers and streams in the northwest German lowlands, which examined the correlation of species presence and community composition with important morphological, physical and chemical properties of the water bodies. We investigated the environmental variables water depth, current velocity, the degree of anthropogenic alteration of river morphology, the $\mathrm{pH}$ and nutrient concentrations $(\mathrm{N}, \mathrm{P}, \mathrm{Ca}, \mathrm{K}, \mathrm{Mg})$ of the sediment and water column, and the concentration of potentially 
harmful elements (e.g. $\mathrm{Cu}, \mathrm{Zn}$ and $\mathrm{Al}$ ). We sought to answer the questions: (1) are there macrophyte species presently occurring only under specifically low or high values of important physical (current velocity) and chemical state factors (availability of $\mathrm{N}$ and $\mathrm{P}$ ) or a low or high degree of anthropogenic influence on river morphology, and (2) which investigated variables differ significantly between the recognizable species assemblages at the reach level?

\section{Materials and methods}

\section{Study area}

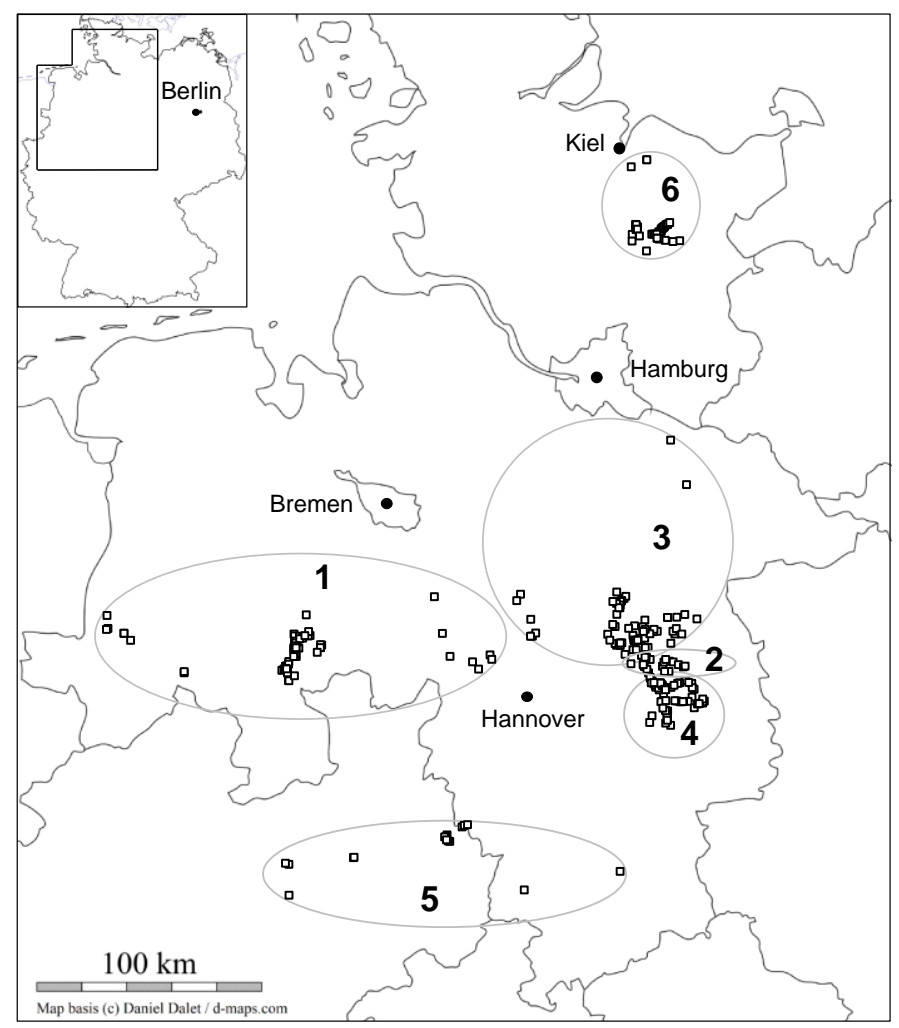

Figure 2.1 Location of the 291 study plots (open squares) in the six study regions of the north-west German lowlands. 1 = Ems-Hunte moraine country, 2 = Aller lowlands, $3=$ Lüneburg Heath, $4=$ northern Harz foothills, 5 = base of the Weser-Leine uplands and $6=$ Eastern Holstein moraine country

The study area is situated in the Pleistocene lowlands of north-west Germany in the states of Lower Saxony, Schleswig-Holstein and North-Rhine-Westphalia at elevations below $210 \mathrm{~m}$ a.s.I. Six study regions with a large number of rivers and streams were selected: 1 . the EmsHunte moraine country; 2. the Aller lowlands; 3. the Lüneburg Heath; 4. the northern Harz foothills; 5 . the basis of the Weser-Leine uplands, and 6. the Eastern Holstein moraines (Figure 2.1). While the river sediments of the study regions 1, 2 and 3 are base-poor, those 
of the regions 4,5 and 6 are moderately base-rich (Table 2.1). The six regions belong to different catchment areas: In region 1, $81 \%$ of the plots are located in the Hunte catchment, $13 \%$ in the Ems catchment; all plots of region 2 refer to the Aller catchment; in region 3, $92 \%$ of the plots are associated with the right-side Aller tributaries, $8 \%$ refer to tributaries of river Elbe; in region 4, $97 \%$ of the plots belong to the Oker catchment; in region 5, $77 \%$ belong to the Leine-Weser system, $23 \%$ to the Rhine catchment; the water courses in region 6 drain into the Baltic Sea and not into the North sea as in all other regions investigated. All rivers receive considerable nutrient loads from the adjacent intensively managed agricultural land. We established a total of 291 study plots in 69 rivers and streams, covering a broad range of water courses of different sizes (1-75 $\mathrm{m}$ width and $0.2->2 \mathrm{~m}$ depth), current velocities (from close to zero to $50 \mathrm{~cm} \mathrm{~s}^{-1}$ ) and sediment types (sandy or loamy with partial coverage by organic deposits, gravel or stones). The catchments of all rivers are part of the cultural landscape of north-west Germany, which consists of a mosaic of arable fields, pastures, meadows, forests and settlements. Due to the oceanic influence, the north-west German lowlands have a humid climate, characterized by warm summers and relatively mild winters with short frost periods. Mean annual temperatures range around $9{ }^{\circ} \mathrm{C}$, with lowest mean temperatures in January $\left(0.4^{\circ} \mathrm{C}\right.$ Braunschweig, Lower Saxony) and highest mean temperatures in July $\left(17.2^{\circ} \mathrm{C}\right.$ for Hannover, Lower Saxony). The average annual precipitation lies between $656 \mathrm{~mm} \mathrm{yr}^{-1}$ (Hannover) and $754 \mathrm{~mm} \mathrm{yr}^{-1}$ (Kiel, Schleswig-Holstein; Deutscher Wetterdienst 2013).

Table 2.1 The six study regions with some characteristics (altitudinal range, minima and maxima of river width and water and sediment $\mathrm{pH}$ ). The dominating substrate types and the most intensively studied rivers are indicated as well

\begin{tabular}{|c|c|c|c|c|c|c|c|}
\hline Region & $\begin{array}{l}\text { No. of } \\
\text { studied } \\
\text { rivers }\end{array}$ & $\begin{array}{l}\text { Altitu- } \\
\text { de [m } \\
\text { a.s.I.] }\end{array}$ & $\begin{array}{l}\text { River } \\
\text { width } \\
\text { [m] }\end{array}$ & $\begin{array}{l}\text { Domina- } \\
\text { ting } \\
\text { substrate } \\
\text { type }\end{array}$ & $\begin{array}{l}\text { pH (water } \\
\text { column) }\end{array}$ & $\begin{array}{l}\text { pH (sedi- } \\
\text { ment) }\end{array}$ & $\begin{array}{l}\text { Most } \\
\text { intensively } \\
\text { studied rivers } \\
\text { (no. of plots) }\end{array}$ \\
\hline Ems-Hunte & 19 & $15-50$ & $1-75$ & Sand & $6.7-9.1$ & $6.3-7.7$ & $\begin{array}{l}\text { Hunte (28), Elze } \\
\text { (5), Lohne (5) }\end{array}$ \\
\hline Aller lowlands & 1 & $30-60$ & $8-40$ & Sand & $8.1-9.1$ & $6.2-7.6$ & Aller (14) \\
\hline $\begin{array}{l}\text { Lüneburg } \\
\text { Heath }\end{array}$ & 23 & $30-60$ & $1-25$ & Sand & $6.7-9.1$ & $4.7-7.4$ & $\begin{array}{l}\text { Lachte (12), } \\
\text { Örtze (12) }\end{array}$ \\
\hline Harz foothills & 12 & $45-160$ & $1-30$ & Sand & $7.2-9.1$ & $6.7-8.0$ & $\begin{array}{l}\text { Schunter (28), } \\
\text { Oker (27) }\end{array}$ \\
\hline $\begin{array}{l}\text { Weser-Leine } \\
\text { uplands }\end{array}$ & 9 & $90-210$ & $3-30$ & Gravel & $7.5-8.4$ & $6.8-7.5$ & $\begin{array}{l}\text { Emmer (6), } \\
\text { Niese (3) }\end{array}$ \\
\hline $\begin{array}{l}\text { Eastern } \\
\text { Holstein }\end{array}$ & 5 & $25-40$ & $2-45$ & Sand & $7.2-8.5$ & $6.6-7.7$ & $\begin{array}{l}\text { Kossau (22), } \\
\text { Schwentine (10) }\end{array}$ \\
\hline
\end{tabular}




\section{Sampling design and field methods}

The sampling design used locations where vegetation relevés had been taken in representative macrophyte stands in the 1930s-1960s (Roll 1939, Weber-Oldecop 1969, R. Tüxen archive: Hoppe 2005); these relevés were analyzed for vegetation change in an earlier study (Steffen et al. 2013). At each of the 291 locations, vegetation was sampled in 2010 or 2011 in plots of $100 \mathrm{~m}^{2}$; the relevés were quadratic if possible. This size was chosen as a compromise because smaller plots are not appropriate for adequately recording river macrophytes that can reach a length of several metres (e.g. Ranunculus fluitans), while larger plots would cover significant environmental gradients in smaller streams (e.g. sediment heterogeneities, Clarke and Wharton 2001). In addition, plot size in most cases exceeded the minimum sampling area required for macrophyte assemblages in streams of up to $10 \mathrm{~m}$ width according to the study of Wiegleb (1983) who found no increase in the number of hydrophyte species in reaches varying between 8 and $250 \mathrm{~m}$ length. Vegetation sampling took place between June and September 2010 and between June and August 2011. All species that rooted below the water level were noted. Cover values were mostly estimated in percent; in a few cases, the traditional Braun-Blanquet scale was used (Dierschke 1994). In every vegetation plot, one $100 \mathrm{ml}$ sediment sample and one $50 \mathrm{ml}$ water sample were taken close to the centre of the water course; the water samples were collected $10 \mathrm{~cm}$ below the water surface. Water and sediment sampling took place in all regions in June 2011 (except for region 6: August 2011). Water and sediment samples were cooled immediately and frozen on the same day for storage until analysis. At each plot, the width and depth of the water body were noted and current velocity in the main current was determined using a floating body and a stopwatch (drift method, Weber-Oldecop 1969). The anthropogenic influence on the riverbed morphology was estimated with a 5-category assessment scheme of naturalness after Brunken (1986) ( 1 = natural structurally diverse water course, 2 = richly structured water course, recognizably impacted by humans, $3=$ straightened water course with numerous natural elements such as pools and rifles, $4=$ straightened water course with a trapezoid cross profile, and 5 (combining categories 5 and 6 of Brunken's system) = completely modified water course structure with artificial bottom and/or bank substrates). Sediment type and type of adjacent vegetation were recorded. Herbarium specimens of all Ranunculus spp. as well as of critical taxa of Potamogeton were collected for later identification. Fresh plant material of Callitriche spp. was collected for identification by an experienced taxonomist.

\section{Water analyses}

The $\mathrm{pH}$ was measured with a $\mathrm{pH}$ meter (EASY $\mathrm{pH}$, WTW, Weilheim, DE). The concentrations of aluminum, calcium, copper, iron, magnesium, manganese, potassium, 
sodium, sulphur and zinc were analysed using ICP-OES (Optima 5300 DV, Perkin Elmer, Rodgau, DE). The concentrations of nitrate, ammonium and phosphate were determined with a Continuous Flow Analyzer (San ${ }^{\text {Plus }}$, photometer SA 6250, Skalar Analytical B.V., Breda, $\mathrm{NL})$.

\section{Sediment analyses}

The $\mathrm{pH}$ was measured in the moist suspension of the original sediment samples with a $\mathrm{pH}$ meter (EASY pH, WTW, Weilheim, DE). For further analyses, the sediment samples were filtered until dropping stopped and passed through a $2 \mathrm{~mm}$ sieve. One part of a sample was dried in a cabinet dryer at $70{ }^{\circ} \mathrm{C}$ for $48 \mathrm{~h}$. The concentrations of total carbon $\left(\mathrm{C}_{\text {total }}\right)$ and total nitrogen $(N)$ in the sediment material and of inorganic carbon $\left(C_{\text {inorg }}\right)$ in the ash were determined with a $\mathrm{C} / \mathrm{N}$-autoanalyzer (Vario EL III, Elementar Analysensysteme $\mathrm{GmbH}$, Hanau, DE). For obtaining the $\mathrm{C}_{\text {org }} / \mathrm{N}_{\text {tot }}$ ratio, $\mathrm{C}_{\text {org }}$ was calculated by subtracting $\mathrm{C}_{\text {inorg }}$ from $\mathrm{C}_{\text {total }}$ with $\mathrm{C}_{\text {inorg }}$ being measured in the ash after ignition of the sediment material at $950{ }^{\circ} \mathrm{C}$. For determining the salt-extractable concentration of cations in the sediment, $2.5 \mathrm{~g}$ of a sediment sample were percolated with $100 \mathrm{ml}$ of $0.2 \mathrm{~N} \mathrm{BaCl}_{2}$-solution and the concentrations of $\mathrm{Al}^{3+}, \mathrm{Ca}^{2+}, \mathrm{Cu}^{2+}, \mathrm{Fe}^{2+}, \mathrm{Mg}^{2+}, \mathrm{Mn}^{2+}, \mathrm{K}^{+}, \mathrm{Na}^{+}$and $\mathrm{Zn}^{2+}$ in the percolate being measured by ICP-OES. We used the resin-bag method for obtaining an estimate of plant-available phosphorus in the sediment; $1 \mathrm{~g}$ of a sediment sample was shaken with a resin bag $\left(4 \mathrm{~cm}^{3}\right.$ anion exchange resin (Dowex 1x8-50, The Dow Chemical Company, Midland, US) sewn in a polyethylene sieve cloth) for $16 \mathrm{~h}$, the adsorbed $\mathrm{P}$ was subsequently re-exchanged by $10 \%$ $\mathrm{NaCl}$ and $2 \% \mathrm{NaOH}$ solutions and the $\mathrm{P}$ concentration in the washing solution determined photometrically at $712 \mathrm{~nm}$ (Libra S22 UV/Vis spectrophotometer, Biochrom Ltd., Cambridge, GB).

\section{Statistical analyses}

In the statistical analyses at the species level, all 291 relevés were included and a total of 31 macrophyte species with a minimum occurrence in 10 plots considered. A Wilcoxon test was used to test for differences between all sites with the occurrence of a species against the sites where the species was absent. Simple logistic regressions were performed with species presence/absence data and environmental variables and tested with an omnibustest to obtain predicted probabilities of species occurrence at a certain parameter value. Analyses at the community level were performed with 47 macrophyte species that occurred at least in five plots. In these analyses, only relevés that contained a minimum of two taxa were included (280). Vegetation classification was done with cluster analysis (Sørensen distance measure, linkage: beta -0.25). Differences in mean values between the eight cluster groups were tested for significance with a Tukey post hoc test. To identify the most relevant 
variables, simple and multiple correlation analyses with backward variable selection were conducted. A Principal Components Analysis (PCA) on the environmental data was also performed to investigate inter-correlations, but the results are not presented, because the explanatory value of the first three components was rather weak $(35 \%)$. In the following variables, each two or three of them were strongly correlated to each other (correlation coefficient $>0.70$ ); river width and depth; $\mathrm{Na}$ and $\mathrm{K}$ concentration (water); $\mathrm{Na}$ and $\mathrm{K}$ concentration (sediment); $\mathrm{Ca}, \mathrm{Mg}$ and $\mathrm{S}$ concentration (water); $\mathrm{Ca}$ and $\mathrm{Mg}$ concentration (sediment); N, C and $\mathrm{C}_{\text {org }}$ concentration (sediment). Thus, only one of these variables each was kept in the analyses.

Diversity was expressed by means of true diversity $D$ (Jost, 2006), $D=e^{H^{\prime}}$, with $H^{\prime}$ being Shannon's diversity index and $D$ the number of species that would be needed to produce the given Shannon diversity value, if cover values were evenly distributed. Red-listed species were identified using the red list for ferns and flowering plants of Germany (Korneck et al. 1996). Plant growth forms were determined after Segal (1968), Mäkirinta (1978) and Wiegleb (1991). An indicator species analysis (ISA) after Dufrêne and Legendre (1997), where indicator values are generated from a combination of a species' abundance and frequency in a particular group, was carried out with PCOrd 5.1 (MjM Software Design, Gleneden Beach, US). The ISA was performed with eight groups and indicator values were assessed for significance using Monte Carlo randomizations with 10000 permutations. A detrended correspondence analysis (DCA, Hill and Gauch 1980), where environmental variables were added in a post hoc manner, was done with Canoco 4.56 (Plant Research International, Wageningen, NL). For statistical tests and correlation analyses, the package SPSS 15.0 (SPSS Inc., Chicago, US) was used.

\section{Results}

\section{Species level}

In total, 94 macrophyte species were recorded, including hydrophytes, amphiphytes and helophytes that rooted in the river bed. The most abundant species were Lemna minor (occurrence in 192 of 291 plots), Sparganium emersum (169 plots), Phalaris arundinacea (161 plots), Callitriche platycarpa (108 plots), Spirodela polyrhiza (107 plots) and Nuphar lutea (93 plots).

Twelve species were found to predominantly occur in habitats of generally large, deep river reaches with low current velocities (Table 2.2 in Appendix). Of those, habitats of Elodea nuttallii, Myriophyllum spicatum, Nuphar lutea, Sagittaria sagittifolia and Spirodela polyrhiza were base- and nutrient-rich (Table 2.3, Figures 2.2a and 2.2b). Hydrocharis morsus-ranae and Potamogeton crispus occurred in more or less alkaline environments, while Ceratophyllum demersum, Lemna minor and Sparganium emersum preferred nutrient-rich 
habitats. The occurrence of $E$. nuttallii and $L$. gibba was related to high turbidity. Of the group of species that were mostly found in potamal reaches, Potamogeton lucens and six other species were associated with low Al concentrations in water and/or sediment.
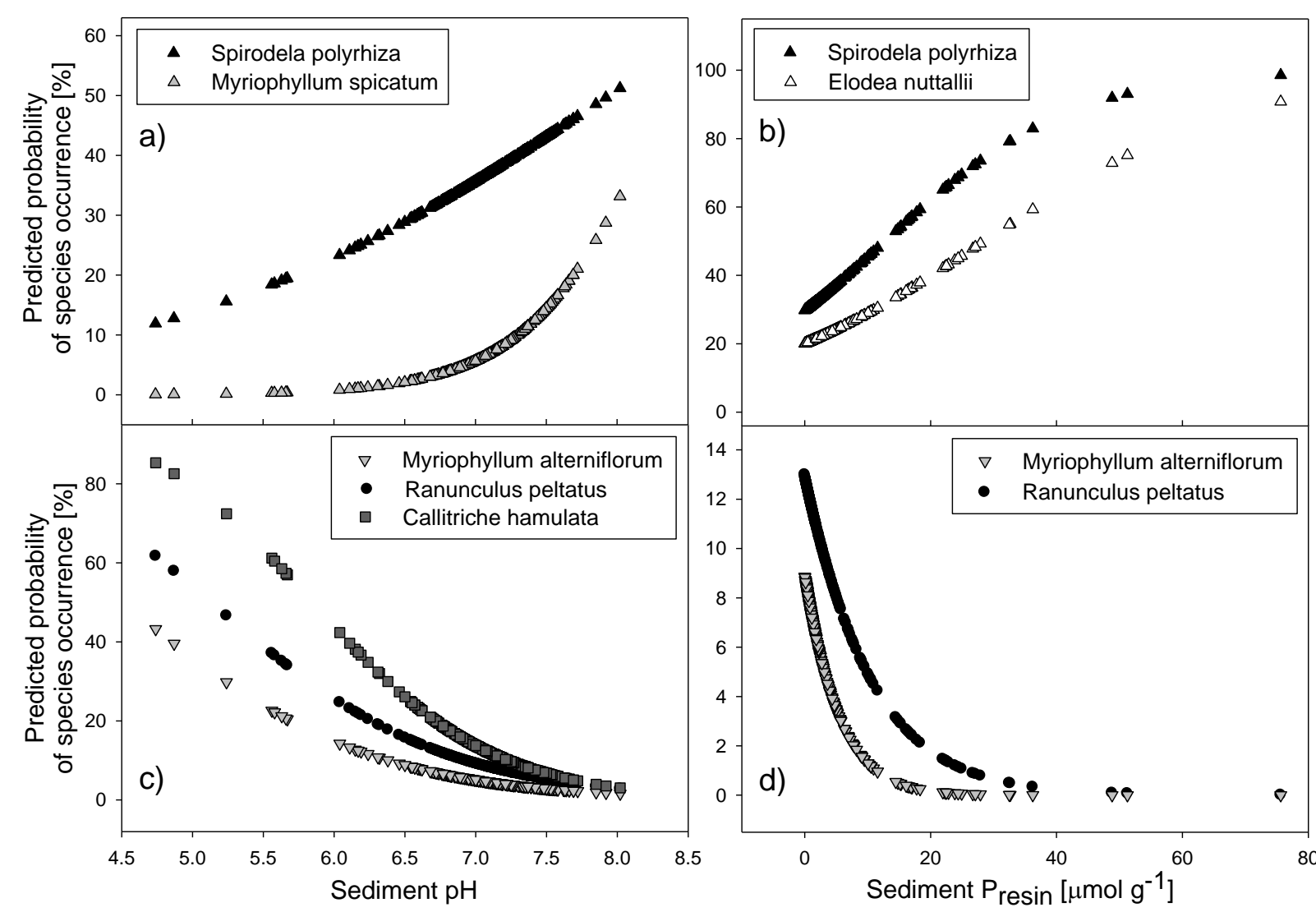

Figure 2.2 Predicted probabilities of occurrence of Callitriche hamulata, Elodea nuttallii, Myriophyllum alterniflorum, M. spicatum, Ranunculus peltatus and Spirodela polyrhiza at different $\mathrm{pH}$ values and concentrations of plant-available phosphorus $\left(\mathrm{P}_{\text {resin }}\right)$ in the sediment (significance levels of the logistic regressions: Table 2.3)

Seven species were found in reaches that were small and shallow, had a close-to-natural structure and were characterized by fast flowing water. Of those, Callitriche hamulata, Myriophyllum alterniflorum and Ranunculus peltatus were related to a significantly lower sediment $\mathrm{pH}$, lower water and sediment $\mathrm{Ca}$ concentration, lower sediment $\mathrm{K}$ and $\mathrm{Na}$ as well as lower water and sediment $\mathrm{Mg}$ concentrations than at the sites where the species were absent (Figure 2.2c). The latter two species were also related to a low $\mathrm{P}$ concentration in the sediment (Figure 2.2d). Berula erecta and Glyceria fluitans occurred in habitats characterized by low sediment $\mathrm{pH}$ values and low $\mathrm{Ca}, \mathrm{P}$ and $\mathrm{Fe}$ concentrations of the sediment. Fontinalis antipyretica occurred in habitats of low sediment $\mathrm{N}$ and $\mathrm{P}$ contents, showing a significantly higher water Mg concentration, compared to sites without the species. Sparganium erectum 
occurred mostly in base-rich habitats. Four species of this group showed an apparent affinity to a high sediment Al concentration.

Behaving indifferently towards water course morphology, Elodea canadensis, Callitriche obtusangula and C. platycarpa were associated with soft water, while Butomus umbellatus, Lemna trisulca, Potamogeton natans, $P$. pectinatus and Utricularia vulgaris occurred in Carich waters. The species Phalaris arundinacea, Phragmites australis, Potamogeton perfoliatus and $P$. pusillus behaved indifferently towards the various parameters studied.

Table 2.3 Results of the omnibus-test for logistic regressions (chi ${ }^{2}$ and $\mathrm{p}$ ) on six selected hydrophyte species and selected environmental variables. Significant correlations $($ at $p<0.1)$ and their directions are indicated: $\downarrow$ for negative and $\uparrow$ for positive relation. CEC - cation exchange capacity

\begin{tabular}{|c|c|c|c|c|c|c|c|c|c|c|c|c|}
\hline & $\begin{array}{l}\text { Current } \\
\text { velocity }\end{array}$ & $\begin{array}{l}\text { pH } \\
\text { (Sed.) }\end{array}$ & $\begin{array}{l}\mathbf{C}_{\text {tot }} \\
\text { (Sed.) }\end{array}$ & $\begin{array}{l}\text { Corg }_{\text {(Sed.) }} \\
\text { (Sed }\end{array}$ & $\begin{array}{l}\mathrm{NH}_{4}{ }^{+} \\
\text {(Wat.) }\end{array}$ & $\begin{array}{l}\mathrm{NO}_{3}{ }^{-} \\
\text {(Wat.) }\end{array}$ & $\begin{array}{l}\mathbf{N}_{\text {tot }} \\
\text { (Sed.) }\end{array}$ & $\begin{array}{l}\mathbf{P}_{\text {resin }} \\
\text { (Sed.) }\end{array}$ & $\begin{array}{l}\text { K } \\
\text { (Sed.) }\end{array}$ & $\begin{array}{l}\mathrm{Na} \\
\text { (Wat.) }\end{array}$ & $\begin{array}{l}\mathrm{Na} \\
\text { (Sed.) }\end{array}$ & CEC \\
\hline \multicolumn{13}{|c|}{ Callitriche hamulata } \\
\hline $\mathrm{Chi}^{2}$ & & $\downarrow 21.3$ & $\downarrow 4.0$ & & $\downarrow 6.1$ & & $\downarrow 3.9$ & & & $\downarrow 4.1$ & $\downarrow 4.0$ & $\downarrow 8.0$ \\
\hline p & & $<0.001$ & 0.046 & & 0.014 & & 0.049 & & & 0.043 & 0.045 & 0.005 \\
\hline \multicolumn{13}{|c|}{ Myriophyllum alterniflorum } \\
\hline $\mathrm{Chi}^{2}$ & $\uparrow 5.1$ & $\downarrow 6.6$ & $\downarrow 14.8$ & $\downarrow 11.9$ & $\downarrow 8.0$ & & $\downarrow 7.3$ & $\downarrow 5.5$ & $\downarrow 5.7$ & $\downarrow 6.2$ & $\downarrow 7.0$ & $\downarrow 16.4$ \\
\hline p & 0.024 & 0.010 & $<0.001$ & 0.001 & 0.005 & & 0.007 & 0.019 & 0.017 & 0.013 & 0.008 & $<0.001$ \\
\hline \multicolumn{13}{|c|}{ Ranunculus peltatus } \\
\hline $\mathrm{Chi}^{2}$ & & $\downarrow 10.6$ & $\downarrow 7.2$ & $\downarrow 3.9$ & & $\uparrow 4.8$ & $\downarrow 3.9$ & $\downarrow 5.1$ & $\downarrow 18.6$ & $\downarrow 20.7$ & $\downarrow 7.3$ & $\downarrow 19.1$ \\
\hline $\mathbf{p}$ & & 0.001 & 0.007 & 0.049 & & 0.029 & 0.050 & 0.023 & $<0.001$ & $<0.001$ & 0.007 & $<0.001$ \\
\hline \multicolumn{13}{|c|}{ Elodea nuttallii } \\
\hline $\mathrm{Chi}^{2}$ & $\downarrow 9.0$ & & $\uparrow 7.0$ & $\uparrow 11.3$ & & & $\uparrow 10.7$ & $\uparrow 10.1$ & $\uparrow 3.4$ & & & \\
\hline $\mathbf{p}$ & 0.003 & & 0.008 & 0.001 & & & 0.001 & 0.001 & 0.064 & & & \\
\hline \multicolumn{13}{|c|}{ Myriophyllum spicatum } \\
\hline $\mathrm{Chi}^{2}$ & $\downarrow 3.8$ & $\uparrow 9.0$ & & & & $\uparrow 2.9$ & & & $\uparrow 11.6$ & $\uparrow 16.3$ & $\uparrow 11.2$ & \\
\hline p & 0.051 & 0.003 & & & & 0.088 & & & 0.001 & $<0.001$ & 0.001 & \\
\hline \multicolumn{13}{|c|}{ Spirodela polyrhiza } \\
\hline $\mathrm{Chi}^{2}$ & $\downarrow 19.0$ & $\uparrow 4.2$ & $\uparrow 14.1$ & $\uparrow 22.9$ & $\uparrow 30.8$ & $\downarrow 28.3$ & $\uparrow 24.7$ & $\uparrow 16.5$ & $\uparrow 3.2$ & $\downarrow 7.0$ & & $\uparrow 28.1$ \\
\hline $\mathbf{p}$ & $<0.001$ & 0.040 & $<0.001$ & $<0.001$ & $<0.001$ & $<0.001$ & $<0.001$ & $<0.001$ & 0.075 & 0.008 & & $<0.001$ \\
\hline
\end{tabular}




\section{Community level}

Species richness per relevé ranged between two and 15. Plot-level species diversity (D) did not show a significant correlation with any of the measured environmental variables (all correlation coefficients $<0.25$ ). The river macrophyte vegetation was grouped into eight clusters by the cluster analysis. Each cluster is characterized by indicator species according to the indicator species analysis (Table 2.4). Cluster $\mathbf{C}$ is characterized by Nuphar lutea, Potamogeton natans and Spirodela polyrhiza, cluster D by Elodea nuttallii and Lemna gibba. The pleustophytic (lemnid, ricciellid and ceratophyllid) and nymphaeid growth forms were grouped in these two clusters, which are mainly found in the Ems-Hunte region (Figure 2.3). Clusters $\mathbf{C}$ and $\mathbf{D}$ corresponded to potamal reaches (Figures 2.4a and 2.4b) with high $\mathrm{C}_{\text {org }}, \mathrm{N}$ and $\mathrm{P}$ concentrations in the sediment (Figures $2.4 \mathrm{c}$ and $2.4 \mathrm{~d}$ ), low water Al concentration, but high $\mathrm{pH}$ and a modified morphological structure of the river bed. These two clusters are characterized by high species richness, high plant coverage and, in the case of cluster $\mathbf{C}$, by a relatively high proportion of red-listed species per relevé (16\%) as well as high diversity (D). Cluster $\mathbf{B}$ is characterized by Sparganium erectum, Potamogeton crispus and Potamogeton pectinatus. The parvopotamids are grouped in this cluster. Assemblages of this cluster mainly occurred in the northern Harz foothills and in Eastern Holstein. It includes a moderately species-rich and diverse community found in habitats with low current velocity, high $\mathrm{Na}$ and $\mathrm{Zn}$ concentrations as well as a rather high $\mathrm{pH}$ of the water (Figures $2.4 \mathrm{e}$ and 2.4f). Cluster $\mathbf{E}$ is characterized, among others, by Myriophyllum alterniflorum and Ranunculus peltatus. This assemblage contains the batrachid species and is moderately species-rich. It prevails in the Lüneburg Heath and the northern Harz foothills regions. It grows in small, shallow reaches with fast flowing water, low sediment $\mathrm{C}_{\text {org }}, \mathrm{N}$ and $\mathrm{P}$ contents as well as low water $\mathrm{Na}, \mathrm{Zn}$ and $\mathrm{pH}$. Together with cluster $\mathbf{F}$, which is characterized by Fontinalis antipyretica and Nasturtium officinale, and cluster $\mathbf{A}$, characterized by Sparganium emersum, Callitriche hamulata and Myriophyllum spicatum, these three clusters contain all myriophyllid and peplid species. Cluster A's community was mainly found in the Lüneburg Heath region in reaches that had a relatively unmodified structure and rather low current velocities. The sediments were of low $\mathrm{Ca}, \mathrm{C}_{\text {total }}$ and $\mathrm{C}_{\text {org }}$ as well as low $\mathrm{N}$ concentrations. Cluster $\mathbf{H}$ with dominant Phragmites australis was mainly present in the Eastern Holstein region. It comprises the most species-poor community in habitats of low sediment $P$ and high Ca concentrations, but low water nitrate content and low pH (Figures $2.4 \mathrm{~g}$ and $2.4 \mathrm{~h}$ ). The reaches of this community had a close-to-natural structure. The habitats of the vegetation grouped in the clusters $\mathbf{F}$ and $\mathbf{G}$, which occurred mainly in the Lüneburg Heath and northern Harz foothills regions, were characterized by rather high current velocities. They did not show any extremes in other environmental parameters. 
Table 2.4 The macrophyte vegetation of the study region as classified into eight assemblages by cluster analysis (in order of increasing adaptation to life in water from A: submerged growth forms, to $\mathrm{H}$ : helophytes). Base figures: relative frequency of species occurrence within a cluster in percent; exponents: cover values as averages within clusters. Indicator species for each cluster were derived from the indicator species analysis

\begin{tabular}{|c|c|c|c|c|c|c|c|c|c|}
\hline $\begin{array}{l}\text { No. of relevés } \\
\text { No. of species } \\
\text { No. of species/r }\end{array}$ & evé & $\begin{array}{l}29 \\
33 \\
6.6 \\
\end{array}$ & $\begin{array}{l}26 \\
36 \\
7.5 \\
\end{array}$ & $\begin{array}{l}78 \\
42 \\
8.9 \\
\end{array}$ & $\begin{array}{l}14 \\
31 \\
8.4 \\
\end{array}$ & $\begin{array}{l}26 \\
31 \\
6.8 \\
\end{array}$ & $\begin{array}{l}46 \\
42 \\
5.8 \\
\end{array}$ & $\begin{array}{l}52 \\
40 \\
6.3 \\
\end{array}$ & $\begin{array}{c}9 \\
12 \\
3.6 \\
\end{array}$ \\
\hline $\begin{array}{l}\text { Indicator } \\
\text { species }^{2)}\end{array}$ & $\begin{array}{l}\text { Growth } \\
\text { form }{ }^{1)}\end{array}$ & A & B & C & D & $E$ & $\mathbf{F}$ & $\mathbf{G}$ & $\mathbf{H}$ \\
\hline \multicolumn{10}{|l|}{ Cluster A } \\
\hline Spar. emer.* & Val. & $100^{24.5}$ & $54^{6.3}$ & $50^{3.6}$ & $64^{2.1}$ & $38^{1.8}$ & $33^{1.1}$ & $94^{2.3}$ & $33^{0.8}$ \\
\hline Call. hamu.* & Pep. & $45^{2.8}$ & - & $6^{1.3}$ & $14^{0.1}$ & $19^{1.3}$ & $15^{1.4}$ & $19^{1.1}$ & - \\
\hline Myri. spic.* & Myr. & $21^{10.3}$ & $19^{1.6}$ & $6^{1.8}$ & - & - & $4^{3.0}$ & $10^{2.9}$ & - \\
\hline Call. stag. & Pep. & $14^{0.5}$ & $8^{0.4}$ & $1^{1.0}$ & - & - & - & $4^{0.6}$ & - \\
\hline Pota. perf. & M-pot. & $10^{5.0}$ & $4^{1.0}$ & $1^{4.0}$ & $14^{0.3}$ & $4^{2.5}$ & $2^{35.0}$ & $4^{1.5}$ & $11^{2.0}$ \\
\hline \multicolumn{10}{|l|}{ Cluster B } \\
\hline Spar. erec.* & Hel. & $21^{1.9}$ & $58^{20.2}$ & $42^{2.9}$ & $21^{0.3}$ & $19^{1.6}$ & $17^{1.3}$ & $38^{2.9}$ & - \\
\hline Pota. pect.* & P-pot. & $24^{2.8}$ & $54^{21.5}$ & $10^{2.5}$ & $7^{25.0}$ & - & $2^{0.0}$ & $10^{3.8}$ & - \\
\hline Pota. cris.* & P-pot. & $7^{0.5}$ & $38^{5.2}$ & $6^{0.7}$ & $14^{7.0}$ & $8^{0.3}$ & $7^{1.5}$ & $6^{0.6}$ & - \\
\hline Buto. umbe.* & Val./Hel. & $10^{2.7}$ & $23^{8.1}$ & $23^{1.9}$ & $7^{0.0}$ & - & - & $12^{1.5}$ & $11^{1.0}$ \\
\hline Phal. arun. & Hel. & $52^{1.3}$ & $81^{2.0}$ & $54^{2.0}$ & $79^{1.4}$ & $58^{1.9}$ & $74^{1 . /}$ & $42^{0.8}$ & $11^{3.0}$ \\
\hline \multicolumn{10}{|l|}{ Cluster C } \\
\hline Nuph. lute.* & Nym. & $7^{0.4}$ & $23^{1.8}$ & $73^{13.8}$ & $29^{8.1}$ & $4^{10.0}$ & $7^{2.3}$ & $37^{2.3}$ & $11^{0.5}$ \\
\hline Sagi. sagi.* & Val./Hel. & $17^{14.5}$ & $23^{4.3}$ & $72^{13.9}$ & $29^{5.5}$ & - & $7^{0.4}$ & $17^{1.5}$ & - \\
\hline Spir. poly.* & Lem. & $21^{0.0}$ & $38^{0.3}$ & $64^{3.9}$ & $79^{0.6}$ & $4^{0.5}$ & $26^{0.6}$ & $21^{0.0}$ & $67^{0.0}$ \\
\hline Utri. vulg.* & Cer. & - & - & $13^{4.3}$ & - & - & - & - & - \\
\hline Pota. nata.* & Nym. & $17^{14.2}$ & $4^{4.0}$ & $31^{13.3}$ & $14^{0.6}$ & - & $2^{1.0}$ & $6^{1 . y}$ & - \\
\hline Pota. pusi.* & P-pot. & - & - & $13^{5.3}$ & - & - & - & - & - \\
\hline Pota. luce.* & M-pot. & $3^{1.5}$ & - & $14^{20.0}$ & - & - & - & $2^{2.0}$ & - \\
\hline Glyc. maxi. ${ }^{*}$ & Val./Hel. & $7^{0.5}$ & $12^{1.5}$ & $33^{5.1}$ & $36^{1.4}$ & $23^{2.4}$ & $22^{1.1}$ & $13^{0.7}$ & - \\
\hline Lemn. mino. & Lem. & $72^{0.1}$ & $77^{0.5}$ & $91^{1.8}$ & $86^{0.5}$ & $35^{1.8}$ & $41^{2.3}$ & $63^{0.1}$ & $78^{0.0}$ \\
\hline Hydr. mors. & Hyd. & - & $8^{0.3}$ & $9^{2.2}$ & $7^{0.1}$ & $4^{0.5}$ & $2^{2.0}$ & - & - \\
\hline Lemn. tris. & Ric. & $3^{0.1}$ & $15^{0.2}$ & $18^{0.2}$ & $21^{0.0}$ & $8^{0.5}$ & $9^{0.0}$ & $6^{0.0}$ & $11^{0.0}$ \\
\hline Cera. deme. & Cer. & - & $12^{2.8}$ & $19^{2.5}$ & $21^{1.2}$ & - & $4^{25.1}$ & - & - \\
\hline \multicolumn{10}{|l|}{ Cluster D } \\
\hline Elod. nutt.* & Elo. & $10^{3.3}$ & $12^{0.5}$ & $49^{2.1}$ & $100^{35.1}$ & $4^{0.5}$ & $11^{2.0}$ & $13^{1.5}$ & - \\
\hline Lemn. gibb.* & Lem. & $3^{0.0}$ & $19^{0.1}$ & $21^{1.3}$ & $29^{2.3}$ & $8^{1.0}$ & $2^{3.0}$ & $2^{0.0}$ & $11^{0.1}$ \\
\hline Pers. amph. & Nym. & - & $4^{0.5}$ & $13^{0.6}$ & $14^{1.0}$ & - & $2^{0.1}$ & $2^{0.5}$ & - \\
\hline Iris pseu. & Hel. & - & - & $1^{0.2}$ & $7^{0.2}$ & - & $2^{0.4}$ & $6^{0.3}$ & - \\
\hline \multicolumn{10}{|l|}{ Cluster E } \\
\hline Beru. erec.* & Hel. & $28^{1.5}$ & $12^{1.0}$ & $10^{1.8}$ & - & $62^{16.1}$ & $20^{2.2}$ & $25^{1.5}$ & - \\
\hline Call. plat.* & Pep. & $41^{1.0}$ & $27^{0.7}$ & $41^{1.1}$ & $21^{0.3}$ & $62^{7.5}$ & $35^{2.0}$ & $42^{0.9}$ & - \\
\hline Plat. ripa. $(\mathrm{M})^{*}$ & Bry. & - & $12^{1.2}$ & - & - & $38^{20.4}$ & $9^{0.3}$ & $4^{0.3}$ & - \\
\hline Ranu. pelt.* & Bat. & $10^{3.1}$ & - & $3^{0.6}$ & $14^{10.0}$ & $38^{12.4}$ & $4^{1.5}$ & $17^{1.7}$ & - \\
\hline Ment. aqua.* & Hel. & $7^{1.8}$ & $8^{2.6}$ & $1^{0.3}$ & - & $42^{5.2}$ & $11^{0.7}$ & $10^{0.8}$ & $11^{1.0}$ \\
\hline Vero. becc.* & Hel. & - & $4^{0.2}$ & $4^{0.6}$ & $7^{1.0}$ & $27^{0.9}$ & $20^{0.5}$ & $6^{0.2}$ & - \\
\hline Myos. palu.* & Hel. & $14^{0.3}$ & $27^{0.3}$ & $27^{0.9}$ & $7^{1.0}$ & $54^{0.6}$ & $26^{0.7}$ & $12^{0.3}$ & $11^{0.1}$ \\
\hline Myri. alte. & Myr. & $10^{0.6}$ & - & $3^{1.5}$ & - & $19^{1.5}$ & $2^{0.3}$ & $10^{3.0}$ & - \\
\hline Agro. stol. & Val./Hel. & $24^{0.8}$ & $19^{0.2}$ & $4^{0.3}$ & $7^{0.5}$ & $23^{1.1}$ & $22^{0.6}$ & $10^{0.2}$ & - \\
\hline Alis. plan. & Hel. & - & - & $10^{0.3}$ & $7^{0.4}$ & $4^{3.0}$ & $2^{0.1}$ & - & - \\
\hline \multicolumn{10}{|l|}{ Cluster F } \\
\hline Font. anti. $(\mathrm{M})^{*}$ & Bry. & $3^{1.0}$ & $4^{0.3}$ & - & - & $15^{0.1}$ & $24^{5.2}$ & $4^{0.6}$ & - \\
\hline Nast. offi. ${ }^{*}$ & Hel. & $10^{0.2}$ & $4^{0.0}$ & $5^{4.1}$ & - & $19^{1.0}$ & $20^{12.5}$ & $2^{0.2}$ & - \\
\hline Ranu. flui. & Myr. & - & - & - & - & - & $9^{13.4}$ & $2^{1.5}$ & - \\
\hline
\end{tabular}




\begin{tabular}{|c|c|c|c|c|c|c|c|c|c|}
\hline \multicolumn{2}{|c|}{$\begin{array}{l}\text { No. of relevés } \\
\text { No. of species } \\
\text { No. of species/relevé }\end{array}$} & $\begin{array}{l}29 \\
33 \\
6.6\end{array}$ & $\begin{array}{l}26 \\
36 \\
7.5 \\
\end{array}$ & $\begin{array}{l}78 \\
42 \\
8.9 \\
\end{array}$ & $\begin{array}{l}14 \\
31 \\
8.4 \\
\end{array}$ & $\begin{array}{l}26 \\
31 \\
6.8\end{array}$ & $\begin{array}{l}46 \\
42 \\
5.8 \\
\end{array}$ & $\begin{array}{l}52 \\
40 \\
6.3 \\
\end{array}$ & $\begin{array}{c}9 \\
12 \\
3.6 \\
\end{array}$ \\
\hline $\begin{array}{l}\text { Indicator } \\
\text { species }^{2)}\end{array}$ & $\begin{array}{l}\text { Growth } \\
\text { form }{ }^{1)}\end{array}$ & A & B & C & D & E & $\mathbf{F}$ & G & H \\
\hline Chil. poly. (M) & Bry. & - & - & - & - & $4^{2.0}$ & $7^{6.8}$ & $2^{0.1}$ & - \\
\hline Elod. cana. & Elo. & $24^{3.8}$ & $15^{4.0}$ & $27^{1.6}$ & $50^{1.1}$ & $23^{1.7}$ & $26^{14.5}$ & $27^{0.5}$ & - \\
\hline Ranu. tric. & Myr. & - & $4^{11.0}$ & - & - & - & $11^{2.2}$ & $2^{0.3}$ & - \\
\hline Glyc. flui. & Val./Hel. & $10^{9.5}$ & $8^{0.6}$ & $4^{2.5}$ & $7^{0.1}$ & $12^{0.5}$ & $15^{5.8}$ & $8^{1.7}$ & - \\
\hline Vero. anag. & Hel. & $3^{0.4}$ & $4^{0.3}$ & $3^{0.3}$ & $7^{0.0}$ & $4^{0.5}$ & $13^{0.2}$ & - & - \\
\hline $\begin{array}{l}\text { Call. obtu. } \\
\text { Cluster G }\end{array}$ & Pep. & - & - & $8^{1.0}$ & $21^{0.5}$ & $4^{4.0}$ & $4^{18.5}$ & - & - \\
\hline $\begin{array}{l}\text { Acor. cala. } \\
\text { Cluster } \boldsymbol{H}\end{array}$ & Hel. & - & $8^{0.5}$ & $3^{0.9}$ & - & - & $7^{0.4}$ & $13^{0.6}$ & - \\
\hline Phra. aust. * & Hel. & $7^{1.0}$ & $15^{2.3}$ & $1^{0.6}$ & - & - & $9^{3.3}$ & $10^{1.6}$ & $100^{10.8}$ \\
\hline
\end{tabular}

1) Bat. = batrachid, Bry. = bryid, Cer. = ceratophyllid, Elo. = elodeid, Hel. = helophytic, Hyd. = hydrocharid, Lem. = lemnid, M-Pot $=$ magnopotamid, Myr. = myriophyllid, Nym = nymphaeid, Pep. $=$ peplid, P-pot. $=$ parvopotamid, Ric. $=$ ricciellid, Val. $=$ vallisnerid

$\left.{ }^{2}\right)^{*}=$ significant indicator species for the respective cluster $(p<0.05),(M)=$ moss

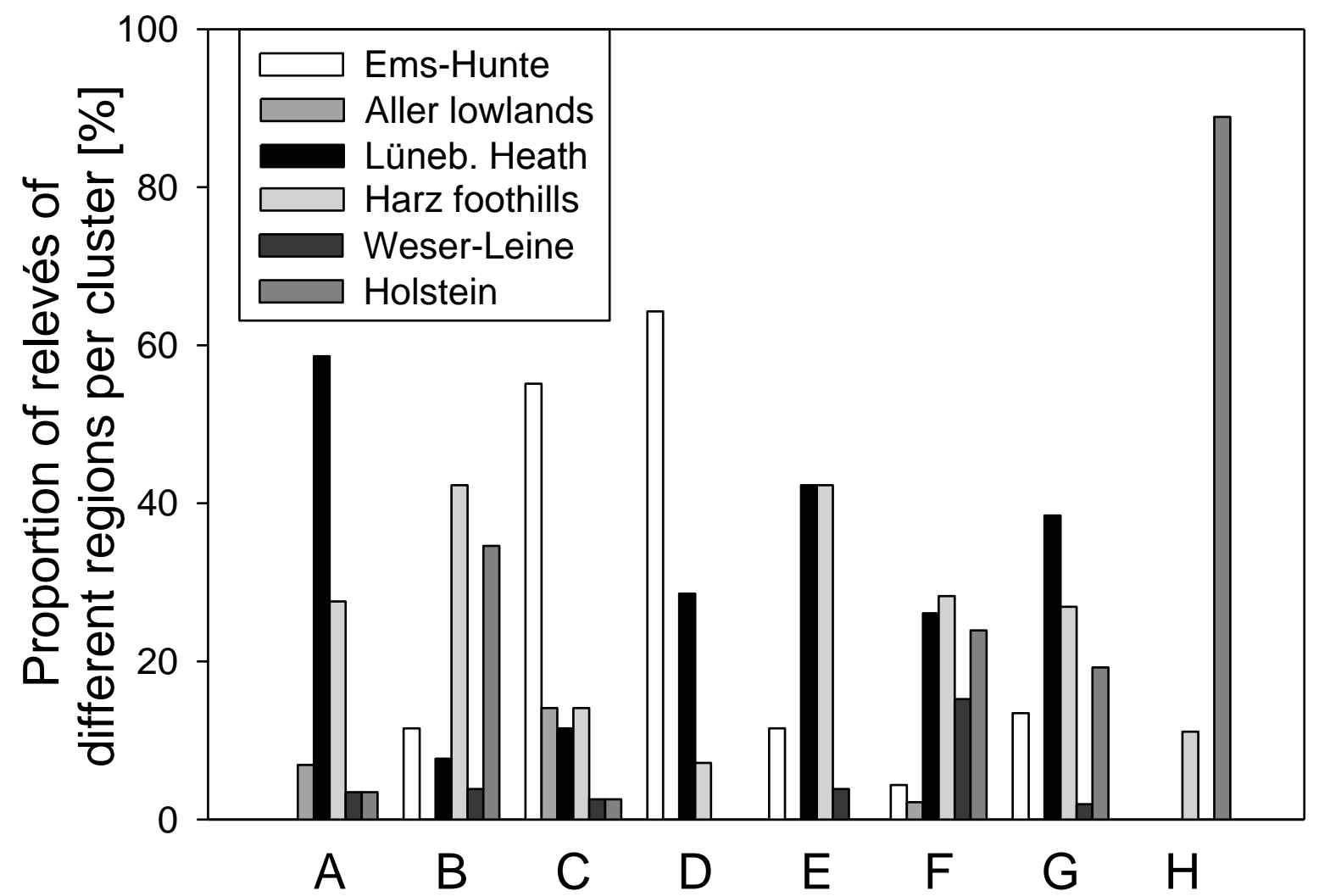

Figure 2.3 Relative contribution (in \%) of relevés from the six study regions to the total number of relevés in the eight vegetation clusters $\mathrm{A}$ to $\mathrm{H}$ 

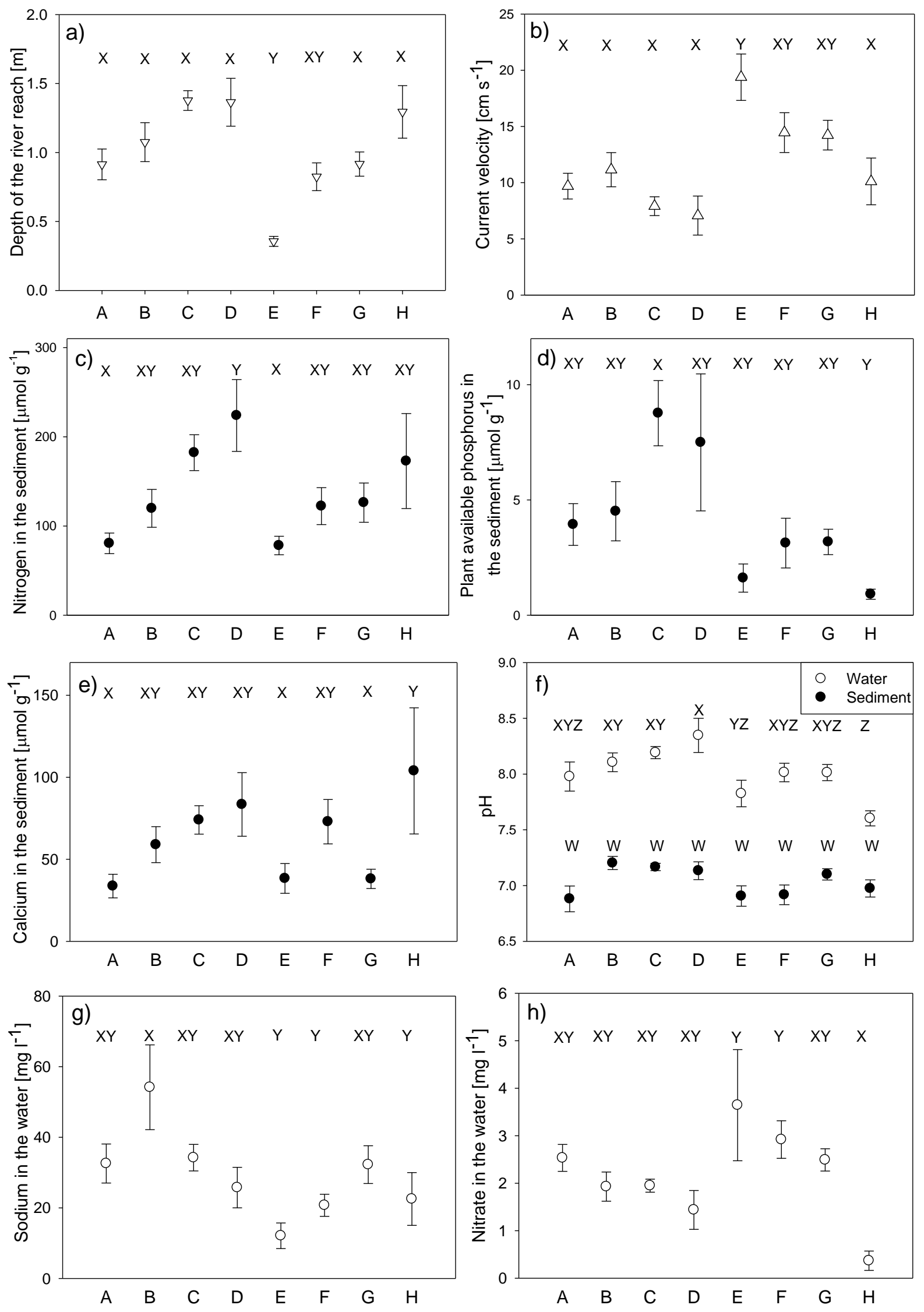

Figure 2.4 a) Depth of water body, b) current velocity, sediment contents of $c$ ) total $N$, d) plant available $\mathrm{P}\left(\mathrm{P}_{\text {resin }}\right)$ and e) calcium, $\mathrm{f}$ ) $\mathrm{pH}$ (water and sediment) and g) sodium and $\mathrm{h}$ ) nitrate in the water in eight macrophyte vegetation clusters $(A$ to $H)$. Means \pm SE of nine to 78 plots sampled in June or August 2011. Different letters ( $W$ to $Z$ ) indicate significant differences between the vegetation clusters 
Of the variables that were identified as being relevant for macrophyte community composition according to multiple regression analysis with backward variable selection, current velocity showed a strong positive correlation with DCA axis 1, water depth a negative one (Figure 2.5, Table 2.5 in Appendix). The $\mathrm{P}, \mathrm{C}_{\text {org }}$ and $\mathrm{Ca}$ concentrations in the sediment, the $\mathrm{NH}_{4}, \mathrm{Fe}$ and $\mathrm{Na}$ concentrations in the water and the anthropogenic influence on the river bed structure were negatively correlated with this axis. The second DCA axis was positively correlated with the $\mathrm{pH}$ of the sediment and negatively with the $\mathrm{Zn}$ concentration in the water.

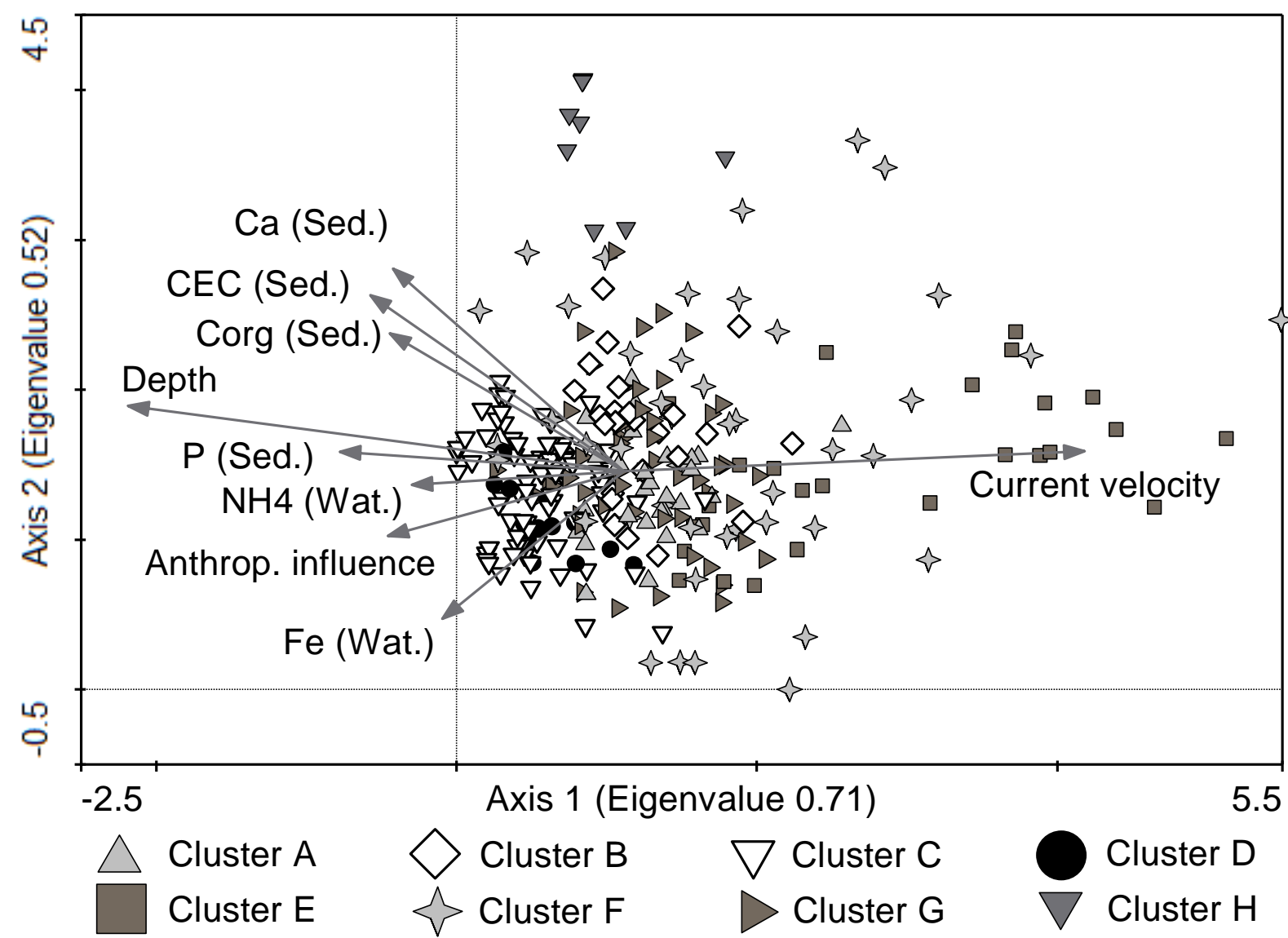

Figure 2.5 DCA of the clustered vegetation (280 relevés, eight groups) and selected environmental variables $($ Wat. $=$ measured in the water column, Sed. $=$ measured in the sediment). For the ordination, species cover values were log-transformed

\section{Discussion}

We focused on a comprehensive analysis of the effects of physical and chemical parameters on community assembly and species distribution of river macrophytes. In order to avoid false conclusions based on pseudocorrelation, we analyzed more than 30 variables including their intercorrelations. At the community level in the six regions, we found seven groups of true macrophyte assemblages in which free-floating species and hydrophytes with submerged or floating leaves rooting in the sediment were dominant. One additional cluster refers to a helophytic community characterized by Phragmites australis. The seven species 
assemblages show a marked differentiation according to the main river habitats colonized by them and also with respect to the relative abundance of macrophyte growth forms. Three clusters are related to nutrient-rich, potamal water course reaches. One of them (cluster B) contains the parvopotamid species including Potamogeton crispus and $P$. pectinatus that are known as eutraphent species (Casper and Krausch 1980). Another two clusters (C and D) contain the pleustophytic and nymphaeid species of the regional species pool. Relevés assigned to those species-rich clusters were mainly taken in the Ems-Hunte region, where the river macrophyte assemblages had earlier been characterized by their abundance of nymphaeid species (Herr et al. 1989, Zander et al. 1992). In eutrophic waters that are often turbid due to phytoplankton blooms, the pleustophytic and nymphaeid growth forms are advantageous, because these plants place their leaves close to or on the water surface and thus escape light competition in the water column (Mesters 1995). In correspondence with the species level analysis, the indicator species for highly eutrophic conditions Elodea nuttallii and Spirodela polyrhiza are characteristic species of these two clusters. One cluster (E) contains the species Myriophyllum alterniflorum and Ranunculus peltatus, which were identified as regional indicators for mesotrophic conditions in our study region. Corresponding conclusions by Weber-Oldecop (1969) and Herr et al. (1989) can be generalized for a wider geographical area. Together with two other clusters ( $A$ and $F$ ), these three assemblages of less nutrient-rich running water reaches contain members of the batrachid, myriophyllid and peplid growth forms, which are adapted to relatively high current velocities. These assemblages are found in the study region mostly in the Lüneburg Heath confirming earlier work by Herr et al. (1989). A similar community with elodeid, peplid and batrachid species was also reported as typical for streams with mesotrophic, neutral conditions in northeast France (Thiébaut and Muller 1999). Cluster $G$ is the second largest one containing more than 50 relevés that lack well-characterized indicative species. It may be termed a 'central cluster' in analogy to the 'central association' in phytosociology, because it contains 'average' relevés in which a dominance of a certain growth form is absent, specific dominance structures do not exist, and the relevés are neither particularly species-rich nor species-poor. This type of vegetation was called 'Sparganium emersum community (various formations)' by Herr et al. (1989, Tab. 16). In Danish lowland streams, the Sparganium community was the predominant vegetation cluster (Riis et al. 2000); the authors assume that the community is promoted by regular mowing. The eighth cluster $(\mathrm{H})$ is only indicated by the helophyte Phragmites australis and is thus somewhat atypical for our macrophyte data set; this cluster includes less than ten species-poor relevés mainly from the Eastern Holstein region. However, Phragmites-dominated vegetation can frequently be found in river reaches off the main current, in particular around the Baltic Sea (Baattrup-Pedersen et al. 2003, Paal 
et al. 2007). Emergent helophytes such as Phragmites are often excluded from sampling or analysis (see e.g. Demars and Harper 1998), as a low indicative value is expected.

The seven vegetation clusters were not only characterized by each one to eight indicator species and characteristic combinations of growth forms, but also by marked differences in certain physical, chemical and river morphological properties. According to the DCA, water depth and current velocity were the two factors with largest influence on the species composition of the studied streams and rivers. This result supports earlier findings that current velocity and related factors play a key role for the structure and composition of the macrophyte vegetation of running waters (see review by Franklin et al. 2008). Even though the informative value of instantaneous flow velocity measurements may be limited because seasonal variability is not captured, a rough classification of flow regimes may be possible, as the measurements were done in summer, when flow rates are typically lower than in winter and spring. The influence of water depth is plausible, because it determines the relative importance of helophytic and pleustophytic species. Chemical properties of the sediment were of secondary importance with $P_{\text {resin }}$ apparently being the most influential element while $\mathrm{N}_{\text {total }}$ and the salt-exchangeable concentrations of $\mathrm{Ca}$ and $\mathrm{Fe}$ in the sediment played subordinate roles. Even less influential were the concentrations of nutrients and other elements in the water column. This agrees with the findings of Demars and Edwards (2009); it is not surprising for several reasons. First, concentrations typically vary considerably over time both diurnally and seasonally. Our data from summer 2011 give only a snapshot of the fluctuation in water chemistry, because the focus of our study was on the sampling of a large number of rivers and vegetation stands. In summer, phosphate and other nutrients are rapidly cycled through the aquatic community with the consequence that actual nutrient concentrations are rarely related to supply rates. Second, intercorrelation with other factors is high and possible effects are difficult to separate from each other (Demars and Harper 1998). In naturally nutrient-rich rivers (in particular of the regions 1,4 and 6), a response to further nutrient enrichment is not very likely (Demars and Edwards 2009).

When comparing the means of our water chemistry data from 291 sampling locations with literature data from other North and Central European streams and rivers, we found in general good agreement (Remy 1993, Schneider and Melzer 2004, Paal et al. 2007). As the samples were mainly taken in June, when nutrient uptake by macrophytes and microalgae (phytoplankton and benthic forms) should be highest, the measured phosphate (mean: 0.03 $\left.\mathrm{mg} \mathrm{L}^{-1}\right)$, nitrate $\left(2.35 \mathrm{mg} \mathrm{L}^{-1}\right)$ and ammonium $\left(0.17 \mathrm{mg} \mathrm{L}^{-1}\right)$ concentrations in the water column were relatively low. In contrast, the sediment concentrations of macronutrients $(N, P$, $\mathrm{Ca}, \mathrm{K}, \mathrm{Mg}$ ) were high at several sites, especially in the regions 1 (Ems-Hunte) and 6 (Eastern Holstein), where intensive agricultural land-use is ubiquitous and the sediment pools are reflecting the 'long-term memory' of the water body. 
At the species level, a number of taxa differed significantly with respect to the physical and chemical properties of their habitats, which became visible when comparing sites with and without occurrence of the target species. The investigated running waters are all in a mesotrophic to eutrophic or even hypertrophic condition (LAWA 1998, NLÖ 2001). Within this range of water conditions, Myriophyllum alterniflorum and Ranunculus peltatus were present in relatively nutrient-poor habitats, as it was stated earlier by Wiegleb (1984) for northern German waters. At the same time, the habitats of these taxa can be categorized as 'rhithral', a term that is most often applied to headwaters flowing through mountainous regions, but also relates to lowland streams of high current velocities and low temperatures due to groundwater inflow (Weber-Oldecop 1970). In the lowlands, rhithral waters are generally not as nutrient-rich as potamal waters, because a river is enriched with nutrients between its close-to-spring rhithral range, where dilution has an effect on element concentrations when groundwater flows in, and its lower potamal range after the passage through an agricultural catchment area. Accordingly, the species Elodea nuttallii, Myriophyllum spicatum and Spirodela polyrhiza, which are generally used as indicators for eutrophic habitats, showed an affinity to potamal river reaches.

That flow velocity is a main structuring force of macrophyte assemblages in rivers, can be expected from the known large species differences in the tolerance of water movement (Sirjola 1969, Brewer and Parker 1990). Less clear are species differences in the response to chemical factors. Macrophyte species have been found to prefer different $\mathrm{N}$ forms which might explain some of the apparent affinities found. For example, a macrophyte species known to prefer ammonium is Potamogeton alpinus that has been observed to show reduced growth in nitrate-enriched water (Boedeltje et al. 2005). Another species with possible preference for $\mathrm{NH}_{4}{ }^{+}$is Elodea canadensis (Melzer and Kaiser 1986, Rolland et al. 1999). Sewage dumping could promote species with ammonium preference. We found several species that were typically present at elevated $\mathrm{NH}_{4}{ }^{+}$water concentrations, but showed no association to higher $\mathrm{NO}_{3}{ }^{-}$concentrations (e.g. Ceratophyllum demersum, Sagittaria sagittifolia, Spirodela polyrhiza). On the other hand, species such as Potamogeton pectinatus, Myriophyllum spicatum, Callitriche hamulata and the moss Fontinalis antipyretica occurred under conditions of elevated $\mathrm{NO}_{3}{ }^{-}$but reduced $\mathrm{NH}_{4}{ }^{+}$levels in our study region. Other chemical factors such as the availability of basic cations $\left(\mathrm{Ca}^{2+}, \mathrm{K}^{+}, \mathrm{Mg}^{2+}\right)$ may be less influential for community composition in our study region, because weakly acidic waters with $\mathrm{pH}<7$ in the water column and low conductivity and cation concentrations were lacking in our sample. 


\section{Conclusions}

Current velocity in combination with the occurrence of characteristic macrophytic growth forms are the most promising parameters for categorizing the river and stream habitats of the north-west German Pleistocene. The rather low indicative value of chemical factors is partly a consequence of the dominant mechanical factors in running waters, but may also be caused by decades of anthropogenic interference, which must have greatly reduced former gradients in water and sediment chemistry as well as hydromorphology across the catchments. Despite some limitations, our study confirmed the indicative value of macrophytes for the abiotic and biotic conditions of streams and rivers as it has been found, e.g. for southern Germany (Poschlod et al. 2010) and other European countries (Birk and Willby 2010). This potential should be used for ecological quality assessment as required by the European Water Framework Directive.

\section{Acknowledgments}

We thank Günther Dersch for the identification of Callitriche spp. and Sebastian Dittrich for the identification of moss species. For help with the chemical analyses we are thankful to Uta Nüsse-Hahne, Ute Schlonsog, Marianne Gscheidlen and Jutta Czernitzki. 


\section{References}

Baattrup-Pedersen, A. \& T. Riis (1999): Macrophyte diversity and composition in relation to substratum characteristics in regulated and unregulated Danish streams. Freshwater Biology 42: 375-385.

Baattrup-Pedersen, A., S.E. Larsen \& T. Riis (2003): Composition and richness of macrophyte communities in small Danish streams - influence of environmental factors and weed cutting. Hydrobiologia 495: 171-179.

Baattrup-Pedersen, A., G. Springe, T. Riis, S.E. Larsen, K. Sand-Jensen \& L.M.K. Larsen (2008): The search for reference conditions for stream vegetation in northern Europe. Freshwater Biology 53: 1890-1901.

Barendregt, A. \& A.M.F. Bio (2003): Relevant variables to predict macrophyte communities in running waters. Ecological Modelling 160: 205-17.

Bernez, I., H. Daniel, J. Haury \& M.T. Ferreira (2004): Combined effects of environmental factors and regulation on macrophyte vegetation along three rivers in western France. River Research and Applications 20: 43-59.

Birk, S. \& N. Willby (2010): Towards harmonization of ecological quality classification: establishing common grounds in European macrophyte assessment for rivers. Hydrobiologia, 652: 149-163.

Boedeltje, G., A.J.P. Smolders \& J.G.M. Roelofs (2005): Combined effects of water column nitrate enrichment, sediment type and irradiance on growth and foliar nutrient concentrations of Potamogeton alpinus. Freshwater Biology 50: 1537-1547

Brewer, C.A. \& M. Parker (1990): Adaptations of macrophytes to life in moving water: upslope limits and mechanical properties of stems. Hydrobiologia 194: 133-142.

Brunken, H. (1986): Zustand der Fließgewässer im Landkreis Helmstedt: Ein einfaches Bewertungsverfahren. Natur und Landschaft 61: 130-133.

Brux, H., W. Herr, D. Todeskino \& G. Wiegleb (1988): A study on floristic structure and dynamics of communities with Potamogeton alpinus $B$. in water bodies of the northern part of the Federal Republic of Germany. Aquatic Botany 32: 23-44.

Butcher, R.W. (1933): Studies on the ecology of rivers: I. On the distribution of macrophytic vegetation in the rivers of Britain. Journal of Ecology 21: 58-91.

Buttler, K.P. \& M. Thieme (2011): Florenliste von Deutschland - Gefäßpflanzen, Version 3. Frankfurt a.M., http://www.kp-buttler.de [08.10.2013]

Casper, S.J. \& H.D. Krausch (1980): Pteridophyta und Anthophyta, 1.Teil: Lycopodiaceae bis Orchidaceae. In: H. Ettl, J. Gerloff, H. Heynig (edts): Süsswasserflora von Mitteleuropa 23. Fischer, Stuttgart: 403 p.

Clarke, S.J. \& G. Wharton (2001): Sediment nutrient characteristics and aquatic macrophytes in lowland English rivers. Science of the Total Environment: 266: 103-12.

Daniel, H., I. Bernez \& J. Haury (2006): Relationships between macrophytic vegetation and physical features of river habitats: The need for a morphological approach. Hydrobiologia 570: 11-17.

Demars, B.O.L. \& D.M. Harper (1998): The aquatic macrophytes of an English lowland river system: assessing response to nutrient enrichment. Hydrobiologia 384: 75-88.

Demars, B.O.L. \& A.C. Edwards (2009): Distribution of aquatic macrophytes in contrasting river systems: a critique 0 the compositional-based assessment of water quality. Science of the Total Environment 407: 975-990.

Demars, B.O.L., J.M. Potts, M. Trémolières, G. Thiébaut, N. Gougelin \& V. Nordmann (2012): River macrophyte indices: not the Holy Grail. Freshwater Biology 57: 17451759 . 
Deutscher Wetterdienst (2013):

http://www.dwd.de/bvbw/appmanager/bvbw/dwdwwwDesktop?_nfpb=true\&_pageLab el=_dwdwww_klima_umwelt_klimadaten_deutschland\&T82002gsbDocumentPath=N avigation\%2FOeffentlichkeit\%2FKlima_Umwelt\%2FKlimadaten\%2Fkldaten_kosten frei\%2Fausgabe_monatswerte_node.html\%3F_nnn\%3Dtrue [14.08.2013]

Dierschke, H. (1994): Pflanzensoziologie. Ulmer, Stuttgart: 683 p.

Dufrêne, M. \& P. Legendre (1997): Species assemblages and indicator species: the need for a flexible asymmetrical approach. Ecological Monography 67: 345-366.

Ellenberg, H. \& C. Leuschner (2010): Vegetation Mitteleuropas mit den Alpen. Ulmer, Stuttgart: $1334 \mathrm{p}$.

Franklin, P., M. Dunbar \& P. Whitehead (2008): Flow control on lowland river macrophytes: a review. Science of the Total Environment 400: 360-378.

Gessner, F. (1955): Hydrobotanik - 1. Energiehaushalt. VEB Deutscher Verlag der Wissenschaften, Berlin: $517 \mathrm{p}$.

Grasmück, N., J. Haury, L. Leglize \& S. Muller (1995): Assessment of the bioindicator capacity of aquatic macrophytes using multivariate analysis. Hydrobiologia 300/301: $115-122$.

Grinberga, L. (2011): Macrophyte species composition in streams of Latvia under different flow and substrate conditions. Estonian Journal of Ecology 60: 194-208.

Grube, H.-J. (1975): Die Makrophytenvegetation der Fließgewässer in Süd-Niedersachsen und ihre Beziehungen zur Gewässerverschmutzung. Dissertation, Göttingen: 456 p.

Haury, J., M.-C. Peltre, M. Trémolieres, J. Barbe, G. Thiébaut, I. Bernez, H. Daniel, P. Chatenet, G. Haan-Archipof, S. Muller, A. Dutartre, C. Laplace-Treyture, A. Cazaubon \& E. Lampert-Servien (2006): A new method to assess water trophy and organic pollution - The Macrophyte biological index for rivers (IBMR): Its application to different types of river and pollution. Hydrobiologia 570: 153-158.

Herr, W., D. Todeskino \& G. Wiegleb (1989): Übersicht über Flora und Vegetation der niedersächsischen Fließgewässer unter besonderer Berücksichtigung von Naturschutz und Land-schaftspflege. Naturschutz und Landschaftspflege in Niedersachsen 18: 145-283.

Herr, W., D. Todeskino \& G. Wiegleb (1990): Survey of macrophytic vegetation in North German water courses. Tasks for Vegetation Science 25: 109-116.

Hill, M.O. \& H.G. Gauch (1980): Detrended correspondence analysis: An improved ordination technique. Vegetatio 42: 47-58.

Holmes, N.T.H., P.J. Boon \& T.A. Rowell (1998): A revised classification system for British rivers based on their aquatic plant communities. Aquatic conservation: Marine and freshwater ecosystems 8: 555-578.

Holmes, N.T.H., J.R. Newman, S. Chadd, K.J. Rouen, L. Saint \& F.H. Dawson (1999): Mean trophic rank: A user's manual. R \& D technical report E38, Environment Agency, Bristol, United Kingdom: 134 p.

Hoppe, A. (2005): Das Reinhold-Tüxen-Archiv am Institut für Geobotanik der Universität Hannover. Tuexenia 25: 463-474.

Janauer, G.A. (1981): Die Zonierung submerser Makrophyten und ihre Beziehung zur Gewässerbelastung am Beispiel der Fischa (Niederösterreich). Verhandlungen der Zoologisch-Botanischen Gesellschaft Österreich 120: 73-98.

Janauer, G.A., U. Schmidt-Mumm \& B. Schmidt (2010): Aquatic macrophytes and water current velocity in the Danube River. Ecological Engineering 36: 1138-1145.

Jost, L. (2006): Entropy and diversity. Oikos 113: 363-375. 
Kohler, A. (1978): Wasserpflanzen als Bioindikatoren. Naturschutz und Landschaftspflege in Baden-Würtemberg Beiheft 11: 245-281.

Koperski, M., M. Sauer, W. Braun \& S.R. Gradstein (2000): Referenzliste der Moose Deutschlands. Schriftenreihe für Vegetationskunde 34: $519 \mathrm{p}$.

Korneck, D., M. Schnittler \& I. Vollmer (1996): Rote Liste der Farn-und Blütenpflanzen (Pteridophyta und Spermatophyta) Deutschlands. Schriftenreihe für Vegetationskunde 28: 21-187.

Kuhar, U., M. Germ, A. Gaberščik \& G. Urbanič (2011): Development of a River Macrophyte Index (RMI) for assessing river ecological status. Limnologica 41: 235-243.

Länderarbeitsgemeinschaft Wasser (LAWA) (1998): Beurteilung der Wasserbeschaffenheit von Fliessgewässern in der Bundesrepublik Deutschland. Chemische Gewässergüteklassifikation. Kulturbuchverlag, Berlin: 69 p.

Mäkirinta, U. (1978): Ein neues ökomorphologisches Lebensformen-System der aquatischen Makrophyten. Phytocoenologia 4: 446-470.

Meilinger, P. (2003): Makrophyten als Bioindikatoren zur leitbildbezogenen Bewertung von Fließgewässern - Ein Beitrag zur Umsetzung der EG-Wasserrahmenrichtlinie. Dissertation, TU München: $128 \mathrm{p}$.

Melzer, A. \& R. Kaiser (1986): Seasonal variations in nitrate content, total nitrogen and nitrate reductase activities of macrophytes from a chalk stream in Upper Bavaria. Oecologia 69: 606-611.

Mesters, C. (1995): Shifts in macrophyte species composition as a result of eutrophication and pollution in Dutch transboundary streams over the past decades. Journal of Aquatic Ecosystem Health 4: 295-305.

Niedersächsisches Landesamt für Ökologie (NLÖ) (2001): Gewässergütebericht 2000. Oberirdische Gewässer 13: 40 p.

Paal, J. \& T. Trei (2004): Vegetation of Estonian watercourses; the drainage basin of the southern coast of the Gulf of Finland. Annales Botanici Fennici 41: 157-177.

Paal, J., T. Trei \& M. Viik (2007): Vegetation of Estonian watercourses III; drainage basins of the Moonsund Sea, the Gulf of Riga and Saaremaa Island. Annales Botanici Fennici 44: $321-344$.

Poschlod, P., M. Kos, S. Roauer, A. Seemann, O. Wiesmann, G. H. Zeltner \& A. Kohler (2010): Long-term monitoring in rivers of south Germany since the 1970s Macrophytes as indicators for the assessment of water quality and its implications for the conservation of rivers. In: Müller, F., Baessler, C., Schubert, H., Klotz, S. (edts): Long-term ecological research. Springer, Dordrecht: 189-199.

Remy, D. (1993): Pflanzensoziologische und standortkundliche Untersuchungen an Fließgewässern Nordwestdeutschlands. Abhandlungen aus dem Westfälischen Museum für Naturkunde 55: $117 \mathrm{p}$.

Riis, T., K. Sand-Jensen \& O. Vestergaard (2000): Plant communities in lowland Danish streams: species composition and environmental factors. Aquatic Botany 66: 255272.

Riis, T. \& K. Sand-Jensen (2001): Historical changes in species composition and richness accompanying perturbation and eutrophication of Danish lowland streams over 100 years. Freshwater Biology 46: 269-280.

Roll, H. (1939): Die Pflanzengesellschaften ostholsteinischer Fließgewässer - Limnologischsoziologische Studien. Archiv für Hydrobiologie 34: 159-305. 
Rolland, T., G. Thiébaut, H. Daniel, M. Trémolières, J. Haury \& S. Muller (1999): Response of nitrate reductase activity to ammonium in three populations of Elodea canadensis Michx. Ecologie 30: 119-124.

Schaumburg, J., C. Schranz, J. Foerster, A. Gutowski, G. Hofmann, P. Meilinger, S. Schneider \& U. Schmedtje (2004): Ecological classification of macrophytes and phytobenthos for rivers in Germany according to the Water Framework Directive. Limnologica 34: 283-301.

Schneider, S. (2007): Macrophyte trophic indicator values from a European perspective. Limnologica 37: 281-289.

Schneider, S. \& A. Melzer (2003): The trophic index of macrophytes (TIM) - A new tool for indicating the trophic state of running waters. International Review of Hydrobiology 88: 49-67.

Schneider, S. \& A. Melzer (2004): Sediment and water nutrient characteristics in patches of submerged macrophytes in running waters. Hydrobiologia 527: 195-207.

Segal, S. (1968): Ein Einteilungsversuch der Wasserpflanzengesellschaften. In: Tüxen, R. (ed.): Pflanzensoziologische Systematik. Junk, The Hague: 191-218.

Sirjola, E. (1969): Aquatic vegetation of the river Teuronjoki, south Finland, and its relation to water velocity. Annales Botanici Fennici 6: 68-75.

Steffen, K., T. Becker, W. Herr \& C. Leuschner (2013): Diversity loss in the macrophyte vegetation of northwest German streams and rivers between the 1950s and 2010. Hydrobiologia 713: 1-17.

Thiébaut, G. \& S. Muller (1999): A macrophyte communities sequence as an indicator of eutrophication and acidification levels in weakly mineralised streams in north-eastern France. Hydrobiologia 410: 17-24.

Weber, H.E. (1976): Die Vegetation der Hase von der Quelle bis Quakenbrück. Osnabrücker Naturwissenschaftliche Mitteilungen 4: 131-190.

Weber-Oldecop, D.W. (1969): Wasserpflanzengesellschaften im östlichen Niedersachsen. Dissertation, TU Hannover: $172 \mathrm{p}$.

Weber-Oldecop, D.W. (1970): Wasserpflanzengesellschaften im östlichen Niedersachsen I. Internationale Revue der gesamten Hydrobiologie 55: 913-967.

Wiegleb, G. (1979): Der Zusammenhang zwischen Gewässergüte und Makrophytenvegetation in niedersächsischen Fließgewässern. Landschaft und Stadt 11: 32-35.

Wiegleb, G. (1983): Recherches méthodologiques sûr les groupements végétaux des eaux courantes. Colloques Phytosociologiques 10 (Vegetations Aquatiques, Lille 1981): 69-83.

Wiegleb, G. (1984): A study of habitat conditions of the macrophytic vegetation in selected river systems in western Lower Saxony (Federal Republic of Germany). Aquatic Botany 18: 313-352.

Wiegleb, G. (1991): Die Lebens- und Wuchsformen der makrophytischen Wasserpflanzen und deren Beziehungen zu Ökologie, Verbreitung und Vergesellschaftung der Arten. Tüxenia 11: 135-147.

Zander, B., U. Wohlfahrt \& G. Wiegleb (1992): Typisierung und Bewertung der Fließgewässervegetation der Bundesrepublik Deutschland, Band I: Text. Carl-vonOssietzky-Universität, Oldenburg: 344 p. 


\section{Chapter 3}

\section{Diversity loss in the macrophyte vegetation of north-west German streams and rivers between the 1950s and 2010}

Kristina Steffen, Thomas Becker, Wolfgang Herr \& Christoph Leuschner

(Hydrobiologia 2013, 713(1), 1-17)
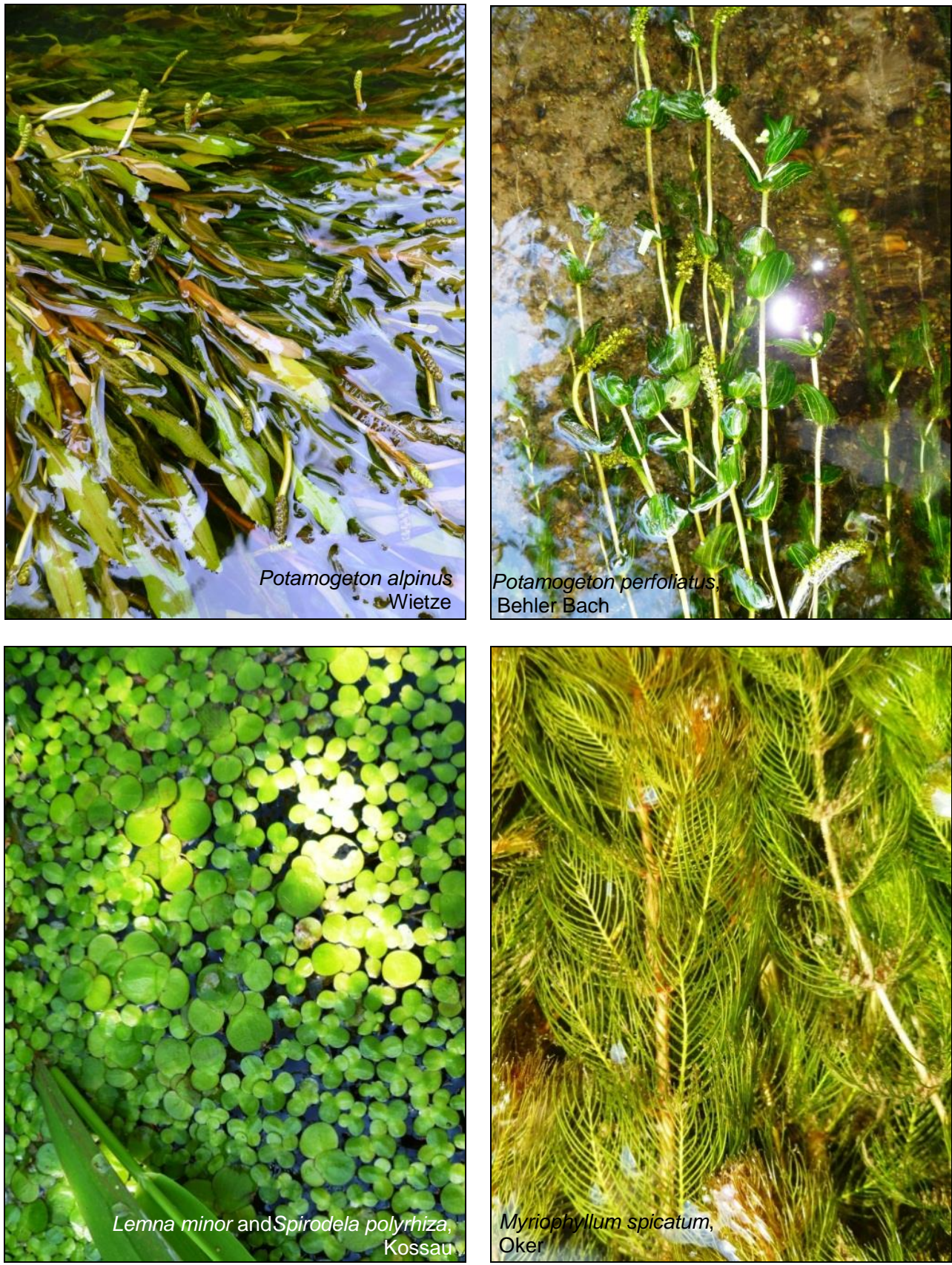


\begin{abstract}
This resampling study in 338 semi-permanent plots analyses changes in river macrophyte diversity in 70 water courses (small streams to medium-sized rivers) from four regions of the north-west German lowlands during the last six decades. The total macrophyte species pool decreased between the 1950 s and $2010 / 2011$ by $27.5 \%$ (from 51 to 37 species), mean plotlevel species richness by $19.4 \%$ (from 4.7 to 3.8 species per relevé) and the number of redlisted species by $40.0 \%$ (from 30 to 18 species). Species loss was associated with marked change in species traits: species with presumably higher mechanical stress tolerance (indicated by low specific leaf area and short leaf longevity) are more abundant today. Nearly half of the species present in the 1950s had either disappeared or been replaced by other species in the recent relevés. The dramatic impoverishment is likely a consequence of continued nutrient input that drove oligo- and mesotraphent species to extinction, and of restructuring and maintenance works in the water courses that reduced stagnant and undisturbed river habitats, where stress-intolerant species can persist. Efficient measures to reduce the nutrient load and to re-naturalize stream and river beds are urgently needed to halt and reverse the loss of macrophyte diversity.
\end{abstract}

Keywords: Aquatic macrophytes, eutrophication, running waters, species traits, vegetation change

\title{
Introduction
}

With less than 100 species, the hydrophytic macrophyte flora (Charophyta, Bryophyta, Pteridophyta and Spermatophyta) of Central Europe's running waters is relatively speciespoor (Casper \& Krausch 1981), but rich in different growth forms reflecting the considerable diversity of habitat types being present in streams and rivers of variable sizes, current velocities, water chemistries and sediment types. With rapidly increasing amounts of fertilizers used in the agricultural landscape and manifold hydro-engineering measures completed, the biota of running waters have been exposed to an ever-increasing pressure in the last century with consequences for macrophyte diversity and community composition (Phillips et al. 1978, Robach et al. 1996, Smith et al. 1999, Egertson et al. 2004, Hilton et al. 2006, Kozlowski \& Vallelian 2009). Eutrophication of water bodies by oxidized and reduced nitrogen compounds, but also by phosphorus, is known to cause profound shifts in the plant community composition of running waters, where rooted macrophytes may eventually be replaced by green macroalgae or phytoplankton as a consequence of light deficiency (SandJensen \& Borum 1991, Vadineanu et al. 1992, Marques et al. 2003). 
Aquatic macrophytes have frequently been used in limnology and vegetation ecology as reliable indicators of habitat conditions in running waters, because various species respond sensitively to alteration in water chemistry and/or current velocity (Kohler \& Schneider 2003, Schaumburg et al. 2004, Daniel et al. 2006, Demars \& Trémolières 2009). As an outcome of macrophyte monitoring, plenty of information exists on the ecological conditions of streams and rivers in many European regions (Pott 1980, Wiegleb 1981, Riis et al. 2000, Kuhar et al. 2007, Grinberga 2011). However, this information is predominantly of qualitative nature and does not provide reliable information on long-term changes in the diversity and composition of the vegetation or alteration in environmental conditions that affect community composition. Only a limited number of studies on long-term change in river macrophyte communities covering several decades exists (Whitton \& Dalpra 1967, Holmes \& Whitton 1977, Herr et al. 1989, Mesters 1995, Whitton et al. 1998, Riis \& Sand-Jensen 2001, Schwieger 2002, Schütz et al. 2008) and an over-regional picture of diversity loss has not yet emerged.

This study uses a semi-permanent plot approach to analyse long-term change in the macrophyte vegetation of 70 streams and rivers from four regions in north-west Germany from the mid of the $20^{\text {th }}$ century until present. We resampled 338 relevés taken between 1936 and 1969 in 2010/2011 and analysed changes in species diversity, abundances of growth forms and functional traits at the community level including specific leaf area (SLA) and the indicator value for nitrogen. For a restricted data set, the temporal development of community change could be analysed between the 1950s, the 1980s and present. The aim of our study was to examine long-term changes in stream and river macrophyte vegetation from an over-regional perspective and, in case of changes, to elucidate the possible drivers of change. More specifically, we asked (1) if the decrease in macrophyte species richness among the 1950s and 2010/2011 was a general phenomenon in all studied river systems, (2) if nutrient-demanding and stress-tolerant species increased proportionally and (3) if community change has been more profound between the 1950s and the 1980s than between the 1980 s and $2010 / 2011$.

\section{Materials and methods}

\section{Study area}

Four regions located in the Pleistocene north-west German lowlands with a variety of small streams to medium-sized rivers were selected for study. Region 1 comprising the EmsHunte moraine (mainly Dümmer lowlands) with acid base-poor moraine soils and bogs; region 2, the Lüneburg Heath (including the Aller lowlands) with base-poor sandy soils, both formed by the penultimate (Saale) Ice Age; region 3, (a) the northern Harz foothills with fertile Pleistocene loess deposits and (b) running waters at the base of the Weser-Leine uplands; and region 4, the eastern Holstein moraine with more base-rich young moraine soils of the 
last (Weichsel) Ice Age (Figure 3.1). Region 3 combines the subregions (a) and (b), because all those sites are situated at the southern edge of the north German Pleistocene lowlands where runoff and groundwater are influenced by the silicate- or carbonate-rich bedrock of the uplands. In total, 70 rivers and streams were sampled (Table 3.1 in the Appendix) covering a broad range of water courses with small to medium size (1-40 m width and 0.2-2 $\mathrm{m}$ depth), current velocities between 0 and $50 \mathrm{~cm} \mathrm{~s}^{-1}$ and sandy or loamy sediments partly overlain by organic deposits or gravel. The catchments of all rivers are part of the cultural landscape of north-west Germany, consisting of a mosaic of arable fields, pastures, meadows, forests and settlements. While the river sediments of the regions 1 and 2 are base-poor and those of the regions 3 and 4 moderately base-rich, in the last decades all streams and rivers have received considerable nutrient loads from the adjacent intensively managed agricultural land (Bundesministerium für Umwelt, Naturschutz und Reaktorsicherheit 2010). Due to the oceanic influence, the north-west German lowlands have a humid climate, characterized by warm summers and relatively mild winters with short frost periods. Mean annual temperatures range around $9^{\circ} \mathrm{C}$, with lowest mean temperatures in January $\left(0.4^{\circ} \mathrm{C}\right.$ Braunschweig, Lower Saxony) and highest mean temperatures in July $\left(17.2^{\circ} \mathrm{C}\right.$ Hannover, Lower Saxony). The average annual precipitation lies between $656 \mathrm{~mm} \mathrm{y}^{-1}$ (Hannover) and $754 \mathrm{~mm} \mathrm{y}^{-1}$ (Kiel, Schleswig-Holstein) (all climate data from Deutscher Wetterdienst 2012).

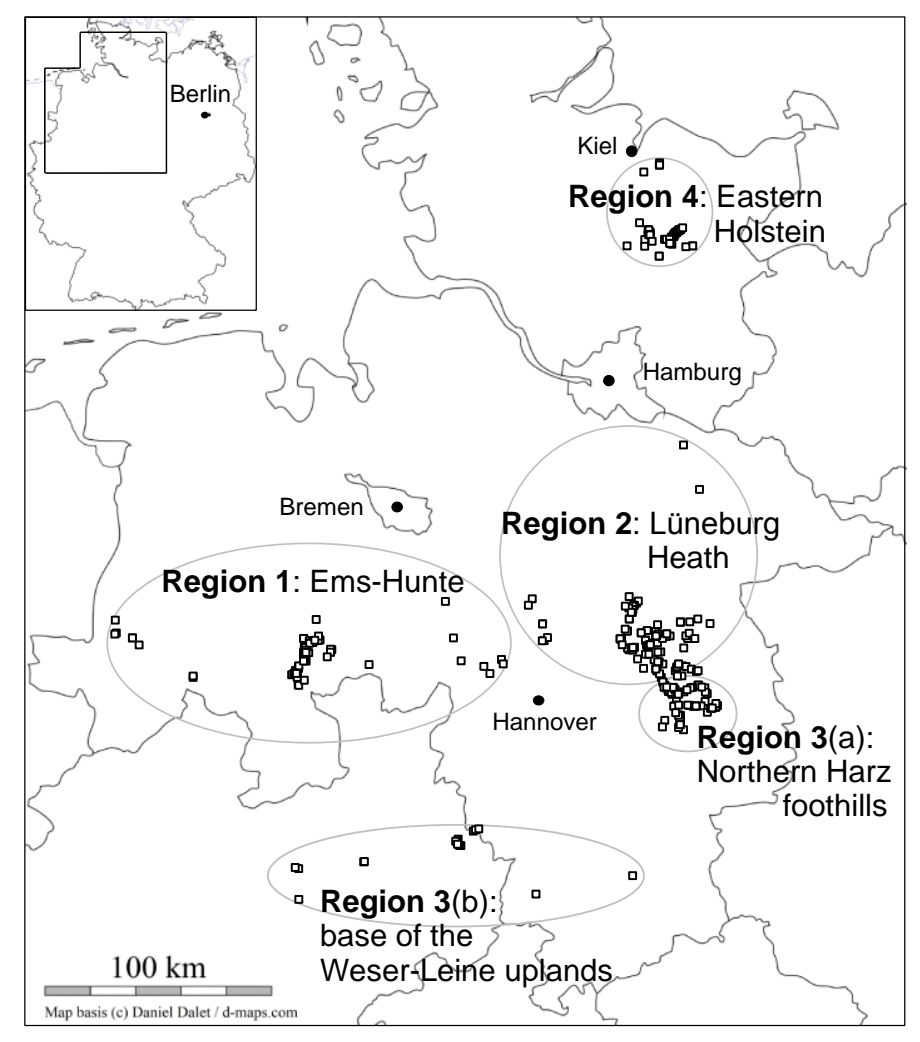

Figure 3.1 Location of the study sites (open squares) within four regions of north-west Germany: region 1 = Ems-Hunte moraine, region 2 = Lüneburg Heath (including the Aller lowlands), region $3=$ (a) Northern Harz foothills and (b) parts of the Weser-Leine uplands and region 4 = Eastern Holstein moraine 


\section{Data basis}

We analysed data sets from three different periods (A: 1936-1969, B: 1983-1986, C: 2010/2011). Set $A$, referred to as the 1950s data, contains 338 relevés from the literature (Roll 1939, Weber-Oldecop 1969) and from the Reinhold-Tüxen-Archive in Hannover (Hoppe 2005). The relevés deposited in the Tüxen archive were mostly taken by Rudolph Alpers in 1946. Set B contains 100 relevés from the 1980s of locations that were all sampled in the periods A and C (Herr \& Wiegleb 1984, Herr 1987). Set C contains present-day data of 338 locations congruent with set $A$. In the analysis, we first compared the data sets A (1950s) and C (2010/2011) (two-step comparison); in a second step, subsets of these two sets were compared with data set B (1980s), because only 100 sites were available that had been sampled in the 1950s, the 1980s and 2010/2011 (three-step comparison). The second analysis examined the time course of community change in more detail and the results are presented in the "Results" section ("Time course of community change: comparing the 1950s, the 1980s and 2010/2011"). Subset AєB contains those data of set $A$ that relate to the 100 locations of set $B$ and subset $C \in B$ includes the data of set $C$ that refer to the 100 locations of set $B$. The plot sizes of the recent relevés (set $C$ ) were chosen in correspondence with the plot sizes of set $A$ (varying between 1 and $100 \mathrm{~m}^{2}$ ). If no plot size was indicated in the historical relevés, a size of $40 \mathrm{~m}^{2}$ was sampled, which is the average of all indicated plot sizes in several hundred relevés from streams and rivers available at the Tüxen archive. No uniform plot size could be achieved in the three-step-comparison (see below under "Methodological restrictions").

\section{Sampling design and field methods}

Historical and recent vegetation analysis was conducted with the relevé method by determining all occurring plant species in a plot and estimating their cover either in percent or (in a few cases) in cover classes according to Braun-Blanquet (see Dierschke 1994). In order to repeat the historical relevés (set $A$ ), the original sampling sites as indicated in the historical sources were revisited in the vegetation periods (June to September) of the years 2010 and 2011. In the reach of a sampling location, we chose a site where the macrophyte vegetation was well developed, because a similar selection procedure had generally been adopted by the authors 60 years ago. Particularly species-poor stands (e.g. under shading trees or next to artificial structures) were not selected. Relevé size was adapted to the size of the respective historical relevé. In addition, a standard plot size of $100 \mathrm{~m}^{2}$ was sampled in 2010/2011 and used for the three-step-comparison. Vegetation was inspected using wade trousers and a telescopic rake was used in deep or very turbid water. The cover values of all macrophyte species that rooted in the river bed below the water level were recorded. In addition, several environmental parameters were recorded, notably the width and depth of 
the water body, flow velocity (determined in the stream line with the drift method as it had been used by Weber-Oldecop, 1969) and the sediment type within the plot.

\section{Data analysis}

Cover values that were available in scores of the scales according to Braun-Blanquet (1964; non-decimal) or Londo (1976; decimal) were transcribed into percentage cover values for every species, using the mean percent value of the respective class. All cover values, including those having been estimated in percent, were then transcribed into the mean percent value of the corresponding Braun-Blanquet class, to obtain consistent scaling among the data sets. Diversity changes were quantified using a modification of Shannon's diversity index, i.e. true diversity $D$ according to Jost (2006), with $D=e^{H^{\prime}}$, where $H^{\prime}$ is Shannon's diversity index and $D$ the number of species that would be needed to produce the given Shannon diversity value, if cover values were evenly distributed. For comparing the species composition of pairs of historical and recent relevés at a site, we calculated the dissimilarity index after Lennon (Lennon et al. 2001) with Lennon DI = $\min (b, c) /[\min (b, c)+a]$, where a is the number of species being present in both relevés, $b$ the number of species only occurring in relevé 1 and c the number of species only occurring in relevé 2 . In contrast to other indices of species turnover, the Lennon DI does not generate high dissimilarities from high differences in species richness, but concentrates on compositional differences with values between 0 (a relevé includes all species of the other relevé) and 1 (no species in common). The current red list of endangered ferns and flowering plants of Germany (Korneck et al. 1996) was used to identify endangered macrophyte species (see Table 3.2 in the Appendix). Plant growth forms were determined after Segal (1968), Mäkirinta (1978) and Wiegleb (1991). Information on pollination types was taken from the BiolFlor data base (Klotz et al. 2002) and on SLA from the LEDA database (Kleyer et al. 2008). The strategy type classification (CRS-system) follows Landolt et al. (2010). Information on leaf longevity and on the species' ecological indicator values for temperature, nitrogen and soil reaction were taken from Ellenberg et al. (2001). The Ellenberg indicator values (EIVs), which are based on vast expert knowledge about the species, have repeatedly been proven for reliably characterizing the environmental conditions of Central European plant communities (Hill et al. 2000, Diekmann 2003, Jansson et al. 2007). They were available for all species occurring in the analysis except for the two aggregates. To facilitate the analyses, similar plant functional groups were aggregated: the pleustophyte group includes lemnids, ricciellids, ceratophyllids and hydrocharids; the potamids contain parvo- and magnopotamids. The group of zoogamous species contains all species pollinated by insects and/or snails. With respect to leaf longevity, only two categories (evergreen and summergreen) were distinguished and the analyses were run with the percental proportion of evergreens. 
All statistical tests and correlation analyses were done with the package SPSS 15.0 (SPSS Inc., Chicago, USA). When two time steps (1950s vs. 2010/2011) were compared and values were normally distributed (according to a Shapiro-Wilk test), the t-test for paired samples was used to test for significance. For data that were not normally distributed and could not be transformed, the non-parametric Wilcoxon-test was used. When three time steps (1950s vs. 1980s vs. 2010/2011) were compared, a repeated measures ANOVA was used to test for differences. In cases, where an overall effect was found, the differences between the groups were further tested with the Bonferroni post hoc test. The species richness estimator indices ACE, ICE, Chao 1, Chao 2, Jackknife 1, Jackknife 2, Bootstrap and MMmeans were calculated from species presence/absence matrices with the software EstimeS 8.20. An indicator species analysis (ISA) after Dufrêne \& Legendre (1997), where indicator values are generated from a combination of a species' frequency and abundance in a particular group, was carried out with PCOrd 5.1. ISA analyses comparing historical and recent samples were performed for each of the four study regions separately and also for the pooled data set across all regions. The indicator values were tested for significance using Monte Carlo randomizations with 9999 permutations (Bakker 2008). A detrended correspondence analysis (DCA) (Hill \& Gauch 1980) was done with Canoco 4.56, where information on environmental and biological traits was correlated with the DCA axes in a post hoc manner. Traits were calculated for each relevé as means (EIVs, SLA) or proportions (growth forms, strategy types, leaf longevity) to be fitted on the ordination space in the form of arrows pointing into the direction in which the value of the variable increases (Leps \& Smilauer 2003). For variables that were not normally distributed we used Spearman correlation, for normally distributed variables Pearson correlation. The respective types of correlation analysis are listed in Table 3.3 in the Appendix.

\section{Methodological restrictions}

To achieve sufficient comparability among the different data sets, only hydrophytic species (plants with morphological adaptations to life in water in the form of submerged or floating leaves) were included in the analyses. Amphiphytes and terrestrial plants, which may have been present in certain relevés when taken at high water, were excluded, because these species were not treated uniformly by the different authors. In the three-stepcomparison (time course analysis), relevés of different sizes had to be compared. The 1950s relevés (subset $A \in B$ ) had the smallest size, the 1980s relevés (set $B$ ) were largest and the $2010 / 2011$ relevés (subset $C € B$ ) were intermediate in size. It thus can be assumed that the species richness in the 1950s may have been rather underestimated, especially when compared to the richness in the 1980s. Despite these methodological shortcomings, it is probable that the species pool of each region was adequately characterized in our analysis 
even with the relatively small relevés of the 1950s, as most water courses were sampled at several sites (see also Figure 3.4).

The reliability of species identification in historical time was not always sufficient. In case of two genera with difficult species determination, aggregates were used throughout the analyses: the species Callitriche cophocarpa Sendtner, C. obtusangula Le Gall de Kerlinou, C. palustris Linnaeus, C. platycarpa Kützing, C. stagnalis Scopoli and C. x vigens Martinsson were summarized to $C$. palustris agg. and the species Ranunculus aquatilis L. and $R$. peltatus von Schrank were summarized to $R$. aquatilis agg. In the text, aggregates and hybrids are referred to as species. The floristic knowledge of the historical author R. Alpers was assumed to be very good; only the fact that he mistook Potamogeton natans L. for $P$. nodosus Poiret (based on his own notes as cited in Herr et al. 1989) was taken into account by correcting for this mistake. Similarly, the species identifications of D.W. Weber-Oldecop were considered to be reliable throughout. Regarding the earliest historical author $\mathrm{H}$. Roll, who worked in region 4 (eastern Holstein), it astonishes that the common macrophyte Sparganium emersum Rehmann did not appear in his species lists. As taxonomical literature was not sufficiently developed in his time, he might have confused this species with Glyceria fluitans (L.) Brown (Weber-Oldecop 1982) or Sparganium erectum L.; however, we did not change any identification into Sparganium emersum in Roll's data for not increasing possible errors.

\section{Results}

\section{Change in floristic composition and diversity between the 1950s and 2010/2011}

In all 676 historical and recent relevés covered by the analysis, 55 hydrophytic macrophyte species were recorded. The number of macrophyte species dropped by $27.5 \%$ from 51 species in the 1950s to 37 species in 2010/2011. Four species [Elodea nuttallii (Blanchon) St. John, Potamogeton praelongus von Wulfen, P. trichoides von Chamisso \& von Schlechtendal and Wolffia arrhiza (L.) Wimmer] were recorded in the recent, but not in the historical survey. On the other hand, 18 species [Helosciadium inundatum (L.) Koch, Hippuris vulgaris L., Juncus bulbosus L., Leptodictyum riparium (Hedwig) Warnstorf, Luronium natans (L.) Rafinesque, Nymphaea alba L., Potamogeton acutifolius Roemer \& Schultes, P. alpinus Balbis, P. angustifolius Presl, $P$. compressus L., $P$. filiformis Persoon, $P$. friesii Ruprecht, $P$. gramineus L., P. obtusifolius Mertens \& Koch, P. polygonifolius Pourret de Figeac, Ranunculus circinatus Sibthorp, Sparganium natans L. and Utricularia australis Brown] were present in the historical, but not in the recent 338 relevés. In region 1 (EmsHunte), the loss in species richness was largest (Table 3.4). Lennon's pairwise dissimilarity between historical and present-day relevés was 0.46 indicating that $46 \%$ of the species of an average relevé pair were different and $54 \%$ of the species were identical. Highest 
dissimilarity between historical and recent relevés (70\%) was observed in the Holstein region and lowest (36\%) in the Lüneburg Heath region. The number of red-listed species present in the study area dropped by $40 \%$ from 30 in the 1950s to 18 in 2010/2011.

Table 3.4 Total number of species and red-listed species in the 1950s and in 2010/2011 and their proportional increase or decrease in the four study regions. The Lennon dissimilarity index describes the quantitative species turnover. The assignment of red-listed status refers to the species' current vulnerability status according to Korneck et al. (1996)

\begin{tabular}{|c|c|c|c|c|c|c|c|}
\hline Region & $\begin{array}{l}\text { No. of } \\
\text { species } \\
1950 \text { s }\end{array}$ & $\begin{array}{l}\text { No. of } \\
\text { species } \\
2010 \\
/ 2011\end{array}$ & $\begin{array}{l}\text { Change in } \\
\text { no. of } \\
\text { species } \\
\text { [\%] }\end{array}$ & $\begin{array}{l}\text { No. of red- } \\
\text { listed } \\
\text { species } \\
1950 \text { s }\end{array}$ & $\begin{array}{l}\text { No. of red- } \\
\text { listed } \\
\text { species } \\
2010 / 2011\end{array}$ & $\begin{array}{l}\text { Change in } \\
\text { no. of red- } \\
\text { listed } \\
\text { species [\%] }\end{array}$ & $\begin{array}{l}\text { Lennon's } \\
\text { dissimi- } \\
\text { larity }\end{array}$ \\
\hline All regions & 51 & 37 & -27.5 & 30 & 18 & -40.0 & 0.46 \\
\hline Ems-Hunte & 37 & 25 & -32.4 & 20 & 9 & -55.0 & 0.49 \\
\hline Lüneburg Heath & 31 & 23 & -25.8 & 14 & 7 & -50.0 & 0.36 \\
\hline Harz foothills & 27 & 25 & -7.4 & 10 & 8 & -20.0 & 0.40 \\
\hline Holstein & 19 & 17 & -10.5 & 11 & 4 & -63.6 & 0.70 \\
\hline
\end{tabular}

The mean number of species per relevé decreased from 4.7 to 3.8 between the $1950 \mathrm{~s}$ and 2010/2011 (Figure 3.2, Table 3.5 in the Appendix). Simultaneously, the percentage of red-listed species per relevé dropped from $20.4 \%$ to $8.6 \%$, indicating a disproportionately larger decrease in this group. Diversity (true diversity D) declined from 2.8 to 2.3 in the whole sample. The indicator species analysis revealed 28 species ( $51 \%$ of the total species pool) to be suitable indicators in at least one region for either recent or historical relevés; in other words, the 28 species showed either a significant decrease or an increase in at least one of the regions (Table 3.6). Twenty-three species showed a decrease or increase between the 1950s and 2010/2011 that was significant in the whole sample and thus independent from the region. Within the species, the direction of change was highly consistent, i.e. nearly all species either increased or decreased in the four regions. However, $77 \%$ of the species with a significant frequency change decreased or increased in only one or two of the four regions pointing to a large regional influence on community change. Only three species (Nuphar lutea (L.), Potamogeton perfoliatus L., Ranunculus aquatilis agg.) showed a decrease in three of the four regions, only one species (Elodea nuttallii) an increase in three regions. The only species, which decreased in all four regions, was the Canadian Waterweed, Elodea canadensis Michaux, which thus served as a highly reliable indicator for running waters of the 1950s. The four regions differed considerably with respect to the number of decreased species. In region 3 (Harz foothills), 15 species decreased, in region 2 (Lüneburg Heath) 13, in region 1 (Ems-Hunte) ten, and in region 4 (eastern Holstein) three. The numbers of species with frequency increase ranged from one to three in the regions. The ratio of 
decreased to increased species was highest in region 2 (ratio of 6.5) followed by region 3 (5.0), region 1 (3.3) and region 4 (3.0), indicating that the losses in species frequency and abundance were high in the Lüneburg Heath and comparably low in the Ems-Hunte region and in eastern Holstein. In all regions together, 21 species decreased and only 2 species increased.

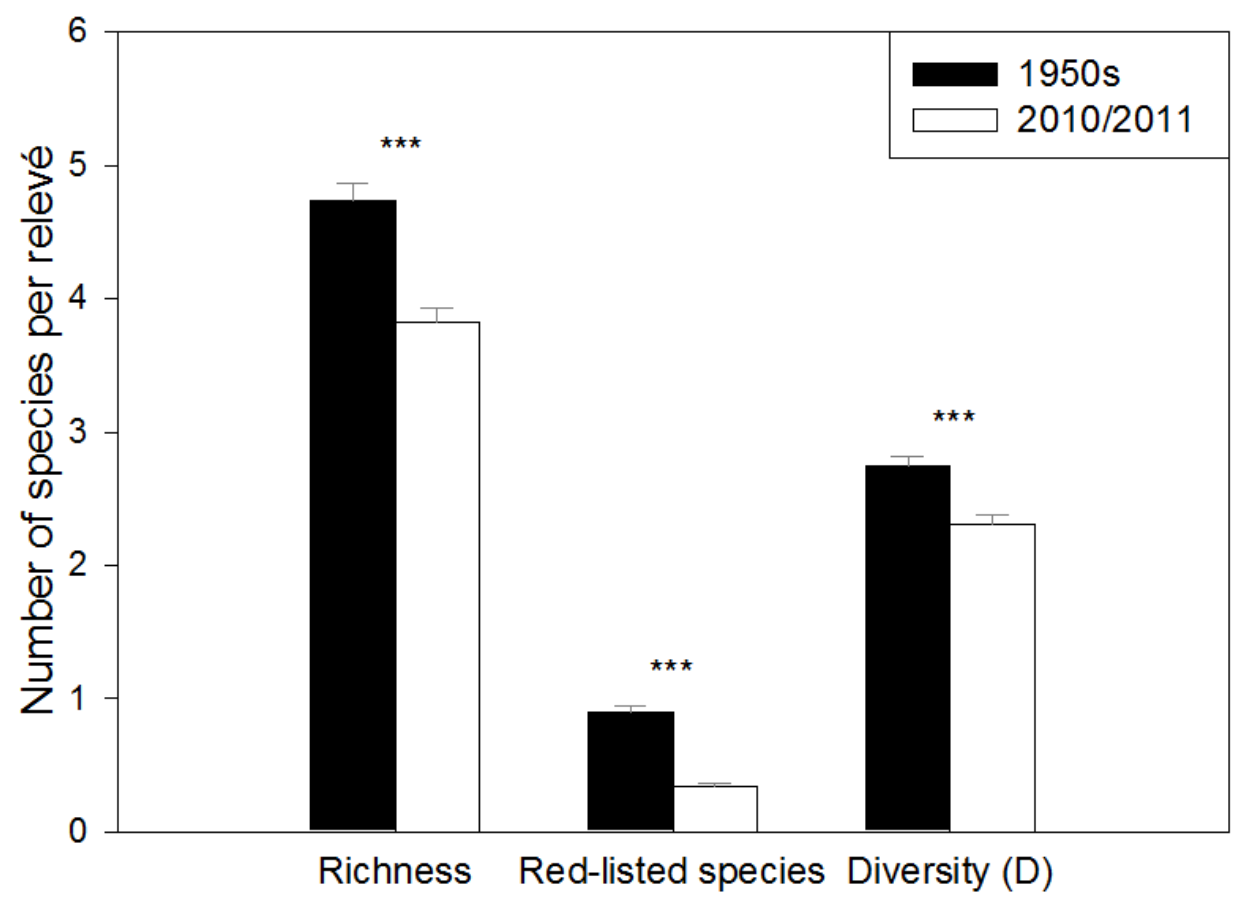

Figure 3.2 Species richness, number of red-listed species and diversity (true diversity $D$ ) per relevé in the 1950s and in 2010/2011 (means \pm SE). Differences significant at $p<0.001$ are marked by ${ }^{* *}$. The assignment of red-listed status refers to the species' current vulnerability status according to Korneck et al. (1996) 
Table 3.6 Macrophyte species of running waters which have increased or decreased in four northwest German regions between the 1950s and 2010/2011. Percent frequency (constancy) values are shown (historical relevés vs. recent relevés). Arrows indicate the direction of change: $\uparrow=$ increase, $\downarrow=$ decrease. The statistics base on the indicator species analysis; only species which have significantly (at $p<0.1)$ decreased or increased at least in one region are listed

\begin{tabular}{lcccc}
\hline All regions & $\begin{array}{c}\text { Region 1 } \\
\text { (Ems-Hunte) }\end{array}$ & $\begin{array}{c}\text { Region 2 } \\
\text { (Lüneburg } \\
\text { Heath) }\end{array}$ & $\begin{array}{c}\text { Region 3 } \\
\text { (Harz foothills) }\end{array}$ & $\begin{array}{c}\text { Region 4 } \\
\text { (eastern } \\
\text { Holstein) }\end{array}$ \\
\hline
\end{tabular}

\section{Decreased species}

\begin{tabular}{|c|c|c|c|c|c|}
\hline Callitriche hamulata & $\downarrow 23.1 \rightarrow 12.1^{* * *}$ & n.s. & $\downarrow 67.6 \rightarrow 28.7^{* * *}$ & n.s. & n.s. \\
\hline Callitriche palustris agg. & $\downarrow 41.4 \rightarrow 32.0^{* \star *}$ & n.s. & $\downarrow 63.9 \rightarrow 47.2^{* *}$ & $\downarrow 56.0 \rightarrow 18.7^{\star \star \star}$ & n.s. \\
\hline Ceratophyllum demersum & n.s. & n.s. & n.s. & $\downarrow 9.9 \rightarrow 3.3+$ & n.s. \\
\hline Elodea canadensis & $\downarrow 39.9 \rightarrow 20.4^{\star \star *}$ & $\downarrow 35.9 \rightarrow 32.1^{* *}$ & $\downarrow 52.8 \rightarrow 26.9^{\star \star *}$ & $\downarrow 20.9 \rightarrow 3.3^{* * *}$ & $\downarrow 50.8 \rightarrow 19.7^{* * *}$ \\
\hline $\begin{array}{l}\text { Fontinalis antipyretica } \\
\text { (moss) }\end{array}$ & $\downarrow 6.8 \rightarrow 3.3+$ & n.s. & $\downarrow 14.8 \rightarrow 1.9^{\star \star \star}$ & n.s. & n.s. \\
\hline Juncus bulbosus fluitans & $\downarrow 2.7 \rightarrow 0.0^{\star \star}$ & n.s. & $\downarrow 8.3 \rightarrow 0.0^{* *}$ & n.s. & n.s. \\
\hline Lemna minor & n.s. & n.s. & n.s. & $\downarrow 52.7 \rightarrow 33.0^{\star *}$ & n.s. \\
\hline Lemna trisulca & $\downarrow 15.1 \rightarrow 9.5^{\star *}$ & $\downarrow 26.9 \rightarrow 21.8^{*}$ & $\downarrow 13.2 \rightarrow 1.1^{* *}$ & n.s. & n.s. \\
\hline $\begin{array}{l}\text { Leptodictyum riparium } \\
\text { (moss) }\end{array}$ & $\downarrow 5.9 \rightarrow 0.0^{* * *}$ & n.s. & $\downarrow 13.0 \rightarrow 0.0^{\star * \star}$ & $\downarrow 6.6 \rightarrow 0.0^{*}$ & n.s. \\
\hline Myriophyllum alterniflorum & $\downarrow 9.5 \rightarrow 4.4^{* * *}$ & n.s. & $\downarrow 28.7 \rightarrow 13.0^{\star * *}$ & n.s. & n.s. \\
\hline Nuphar lutea & $\downarrow 34.6 \rightarrow 24.0^{\star \star \star}$ & $\downarrow 62.8 \rightarrow 51.3^{* *}$ & n.s. & $\downarrow 24.2 \rightarrow 18.7^{*}$ & $\downarrow 32.8 \rightarrow 11.5^{\star * *}$ \\
\hline Potamogeton alpinus & $\downarrow 5.3 \rightarrow 0.0^{* * *}$ & n.s. & $\downarrow 13.9 \rightarrow 0.0^{* * *}$ & n.s. & n.s. \\
\hline Potamogeton crispus & $\downarrow 18.3 \rightarrow 7.4^{* * *}$ & $\downarrow 16.7 \rightarrow 6.4^{*}$ & n.s. & $\downarrow 42.9 \rightarrow 17.6^{* * *}$ & n.s. \\
\hline Potamogeton friesii & $\downarrow 9.5 \rightarrow 0.0^{* \star *}$ & n.s. & n.s. & $\downarrow 27.5 \rightarrow 0.0^{\star \star *}$ & n.s. \\
\hline Potamogeton lucens & $\downarrow 10.9 \rightarrow 3.0^{* * *}$ & $\downarrow 26.9 \rightarrow 9.0^{\star \star \star}$ & n.s. & n.s. & $\downarrow 24.6 \rightarrow 0.0^{* * *}$ \\
\hline Potamogeton natans & $\downarrow 30.5 \rightarrow 10.4^{* * *}$ & $\downarrow 62.8 \rightarrow 26.9^{\star \star \star}$ & n.s. & $\downarrow 39.6 \rightarrow 2.2^{\star \star *}$ & n.s. \\
\hline Potamogeton obtusifolius & $\downarrow 1.5 \rightarrow 0.0+$ & n.s. & n.s. & n.s. & n.s. \\
\hline Potamogeton pectinatus & $\downarrow 16.0 \rightarrow 10.4^{\star *}$ & $\downarrow 12.8 \rightarrow 5.1^{*}$ & n.s. & $\downarrow 37.4 \rightarrow 28.6^{*}$ & n.s. \\
\hline Potamogeton perfoliatus & $\downarrow 12.4 \rightarrow 3.0^{* *}$ & $\downarrow 21.8 \rightarrow 3.8^{* * *}$ & $\downarrow 9.3 \rightarrow 1.9^{*}$ & $\downarrow 6.6 \rightarrow 2.2+$ & n.s. \\
\hline Potamogeton pusillus & $\downarrow 6.8 \rightarrow 3.6^{\star \star}$ & n.s. & n.s. & $\downarrow 15.4 \rightarrow 0.0^{* * *}$ & n.s. \\
\hline Ranunculus aquatilis agg. & $\downarrow 23.4 \rightarrow 8.0^{* \star *}$ & $\downarrow 9.0 \rightarrow 2.6+$ & $\downarrow 59.3 \rightarrow 23.1^{* * *}$ & $\downarrow 8.8 \rightarrow 0.0^{* *}$ & n.s. \\
\hline Ranunculus fluitans & $\downarrow 4.7 \rightarrow 2.4^{\star}$ & n.s. & n.s. & n.s. & n.s. \\
\hline Sparganium emersum & $\downarrow 52.1 \rightarrow 52.1^{* * *}$ & $\downarrow 41.0 \rightarrow 33.3^{*}$ & $\downarrow 79.6 \rightarrow 78.7+$ & $\downarrow 63.7 \rightarrow 50.5^{* * *}$ & $\uparrow 0.0 \rightarrow 31.1^{* * *}$ \\
\hline \multicolumn{6}{|l|}{ Increased species } \\
\hline Elodea nuttallii & $\uparrow 0.0 \rightarrow 19.8^{* * *}$ & $\uparrow 0.0 \rightarrow 41.0^{* * *}$ & $\uparrow 0.0 \rightarrow 26.9^{* * *}$ & $\uparrow 0.0 \rightarrow 6.6^{*}$ & n.s. \\
\hline Lemna gibba & n.s. & $\uparrow 2.6 \rightarrow 17.9^{* * *}$ & $\uparrow 2.8 \rightarrow 9.3^{* *}$ & $\downarrow 20.9 \rightarrow 6.6^{* *}$ & n.s. \\
\hline Myriophyllum spicatum & $\uparrow 0.9 \rightarrow 5.6^{* * *}$ & n.s. & n.s. & $\uparrow 1.1 \rightarrow 17.6^{\star * *}$ & n.s. \\
\hline Spirodela polyrhiza & n.s. & $\uparrow 21.8 \rightarrow 59.0+$ & n.s. & $\uparrow 2.2 \rightarrow 9.9^{*}$ & n.s. \\
\hline \multicolumn{6}{|c|}{ Species without overall increase or decrease } \\
\hline $\begin{array}{l}\text { Chiloscyphus polyanthos } \\
\text { (liverwort) }\end{array}$ & n.s. & n.s. & $\downarrow 4.6 \rightarrow 0.0+$ & $\uparrow 0.0 \rightarrow 5.5+$ & n.s. \\
\hline $\begin{array}{l}\text { Numbers of decreased / } \\
\text { increased species }\end{array}$ & $21 / 2$ & $10 / 3$ & $13 / 2$ & $15 / 3$ & $3 / 1$ \\
\hline
\end{tabular}

n.s. $=$ non-significant, $+=p<0.1,{ }^{*}=p<0.05,{ }^{* *}=p<0.01,{ }^{* *}=p<0.00$ 


\section{Change in vegetation structure and biological traits between the 1950s and 2010/2011}

The pleustophytic growth form types as well as vallisnerids increased in relative abundance from the 1950s to 2010/2011. In contrast, peplids, potamids, batrachids and nymphaeids declined. Isoetids disappeared completely (Figure 3.3, Table 3.7 in the Appendix). Competitor-strategists proportionally declined, while ruderal- and stressstrategists increased. The abiotic pollination types anemogamy and hydrogamy declined in the study area, while the relative frequency of self-pollinated macrophyte species and species pollinated by insects or snails increased. Species with evergreen leaves showed a decline, while the proportion of summergreen (short-lived) species increased. Species with a high specific leaf area, i.e. with leaves and lamina rich in aerenchymatic tissue, proportionally declined from the 1950s to 2010/2011 (Table 3.8).

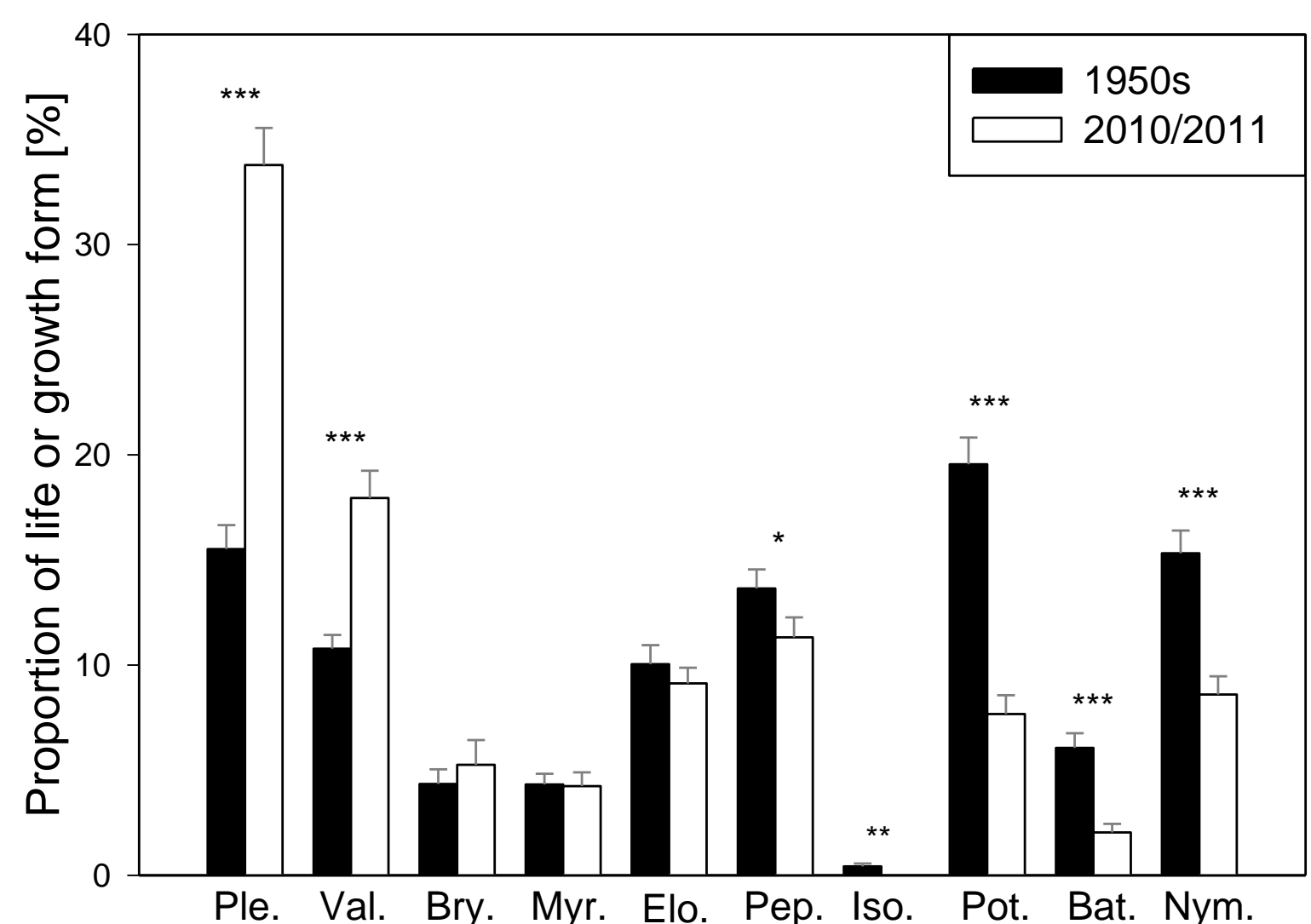

Figure 3.3 Proportions of the different growth forms in the total number of species in the relevés of the 1950s and 2010/2011 (means \pm SE of 338 relevés); Ple. = pleustophytes (lemnids, ricciellids, ceratophyllids, hydrocharids), Val. = vallisnerids, Bry. = bryids, Myr. = myriophyllids, Elo. = elodeids, Pep. $=$ peplids, Iso. $=$ isoetids, Pot. = parvo and magnopotamids, Bat. = batrachids, Nym. = nymphaeids. Significant differences are indicated $\left({ }^{* * *}=p<0.001,{ }^{* *}=p<0.01,{ }^{*}=p<0.05\right)$ 
Table 3.8 Relative abundance of life strategies (CRS-classification), pollination types, leaf properties and mean Ellenberg indicator values among the species of the relevés from the 1950s and from 2010/2011. Mean values are shown

\begin{tabular}{llllll}
\hline Trait & 1950s & $\begin{array}{l}\mathbf{2 0 1 0 /} \\
\mathbf{2 0 1 1}\end{array}$ & $\begin{array}{l}\text { Direction of }_{\text {change }^{1}} \\
\text { C-strategists [\%] }\end{array}$ & $\begin{array}{l}\text { T (paired t-test) / } \\
\mathbf{Z} \text { (Wilcoxon test) }\end{array}$ & p \\
R-strategists [\%] & 23.9 & 18.9 & $\downarrow$ & $\mathrm{T}=5.9$ & $<0.001$ \\
S-strategists [\%] & 11.2 & 14.5 & $\uparrow$ & $\mathrm{Z}=-4.2$ & $<0.001$ \\
Anemogamy [\%] & 64.9 & 66.6 & $\uparrow$ & $\mathrm{Z}=-4.2$ & $<0.001$ \\
Hydrogamy [\%] & 43.5 & 40.6 & $\downarrow$ & $\mathrm{Z}=-3.4$ & $<0.001$ \\
Autogamy [\%] & 28.5 & 24.6 & $\downarrow$ & $\mathrm{Z}=-2.1$ & 0.035 \\
Zoogamy [\%] & 10.2 & 11.3 & $\uparrow$ & $\mathrm{Z}=-3.2$ & 0.001 \\
Evergreen species [\%] & 17.8 & 23.6 & $\uparrow$ & $\mathrm{Z}=-4.7$ & $<0.001$ \\
SLA [m ${ }^{2} \mathrm{~kg}^{-1}$ ] & 72.5 & 55.8 & $\downarrow$ & $\mathrm{Z}=-7.5$ & $<0.001$ \\
EIV for temperature & 37.9 & 29.4 & $\downarrow$ & $\mathrm{Z}=-8.7$ & $<0.001$ \\
EIV for soil reaction & 5.5 & 5.5 & $\uparrow$ & $\mathrm{Z}=-1.9$ & 0.059 \\
EIV for nitrogen & 6.6 & 6.6 & - & $\mathrm{Z}=-1.1$ & 0.271 \\
\hline
\end{tabular}

${ }^{1} \downarrow=$ decrease, $\uparrow=$ increase

\section{Change in environmental conditions between the 1950s and 2010/2011}

The mean Ellenberg indicator values (EIV) for nitrogen and for temperature, calculated by averaging over all species of a relevé, have increased during the six decades of study (Table 3.8). No change was observed for the EIV for soil reaction $(\mathrm{pH})$. Some major changes (significant at $p<0.001$ ) in river hydrography took place since the 1950s: Across all 70 water courses, we found an increase in the mean width of the water course (from $7.8 \mathrm{~m}$ to $10.1 \mathrm{~m}$ ), an increase in mean water depth (from $0.8 \mathrm{~m}$ to $1.1 \mathrm{~m}$ ), but an apparent decrease in mean current velocity in the stream line (from c. $0.30 \mathrm{~m} \mathrm{~s}^{-1}$ to c. $0.12 \mathrm{~m} \mathrm{~s}^{-1}$ ). The relative abundance of the different sediment types (more than $50 \%$ sand followed by gravel/stones, mud and loam in the order of decreasing frequency) remained relatively stable over time (Table 3.9). However, while all rivers were still flowing in their natural beds in the 1950s, reaches of the stream Bruchgraben and the river Grawiede (both region 1) have been restructured by cementation since then. 
Table 3.9 Proportion of different sediment types in the 1950s and in 2010/2011 (145 sites, where information from the 1950s and 2010/2011 was available, are included)

\begin{tabular}{lcc}
\hline Sediment type & Proportion in the 1950s [\%] & Proportion in 2010/2011 [\%] \\
\hline Sand & 55.18 & 58.12 \\
Gravel / stones & 22.30 & 19.77 \\
Mud & 13.45 & 15.75 \\
Loam & 6.78 & 3.47 \\
Other (natural) & 2.30 & 2.20 \\
Other (artificial) & 0.00 & 0.70 \\
\cline { 2 - 3 } & 100.00 & 100.00 \\
\hline
\end{tabular}

\section{Time course of community change: comparing the 1950s, the 1980s and 2010/2011}

The detailed temporal analysis with 100 plots studied in the 1950s, the 1980s and at present showed over all regions a continuous decline in total vegetation cover in the relevés from $57 \%$ in the 1950 s to $43 \%$ in the 1980 s and to $28 \%$ in $2010 / 2011$. The absolute number of species present declined by $15 \%$ between the 1950 s and the 1980 s and by another $12 \%$ between the 1980s and 2010/2011. Comparison of the number of observed species with the estimated number of species according to species richness estimator indices confirms that our analysis captured the present species pool to a large extent in all three sampling periods (Figure 3.4). Despite the more or less continuous decrease in the over-regional macrophyte species pool size, the four regions followed individual patterns of change. A decrease between the 1950s and the 1980s in the total number of species present ( -19 to $36 \%$ ) was recorded only in two of the regions (Ems-Hunte and Harz foothills) and none of the regions showed species pool declines of more than $6 \%$ between the 1980 s and 2010/2011 (Figure 3.5a). This pattern was different for the number of red-listed species with decreases of 17-59\% in two regions (Ems-Hunte and Holstein) between the 1950s and the 1980 s and further decreases of $20-25 \%$ in all regions except region 1 (Ems-Hunte) in the subsequent second time interval (Figure 3.5b). The change in species composition between the 1950 s and the 1980 s (42\% of species exchanged) was more profound than the species turnover between the 1980 s and $2010 / 2011$ (37\% of species exchanged).

Rhizophytes with floating leaves, represented by the growth form types nymphaeids and batrachids, declined between the 1950s and the 1980s, while potamids show a decline between the 1980s and 2010/2011. Pleustophytes increased between the 1980s and 2010/2011 (Figure 3.6, Table 3.10 in the Appendix). The relative abundance of species with a competitor strategy proportionally declined between the 1950s and 2010/2011 (Figure 3.7a, Table 3.10 in the Appendix). In contrast, stress-tolerating species increased in the sixty years, while species with a ruderal strategy increased between the 1950s and the 1980s. We found a shift from a high proportion of evergreen species to a high proportion of 
summergreen species for the period from the 1980s to 2010/2011 (Figure 3.7b). The average specific leaf area (SLA) of the species declined from c. 37 to c. $29 \mathrm{~m}^{2} \mathrm{~kg}^{-1}$ with a large drop since the 1980s (Figure 3.7c). The mean Ellenberg indicator value for nitrogen strongly increased between the 1950s and the 1980s, but showed a tendency to decrease thereafter (Figure 3.7d). The EIV for soil reaction showed a similar pattern with a peak in the 1980s.

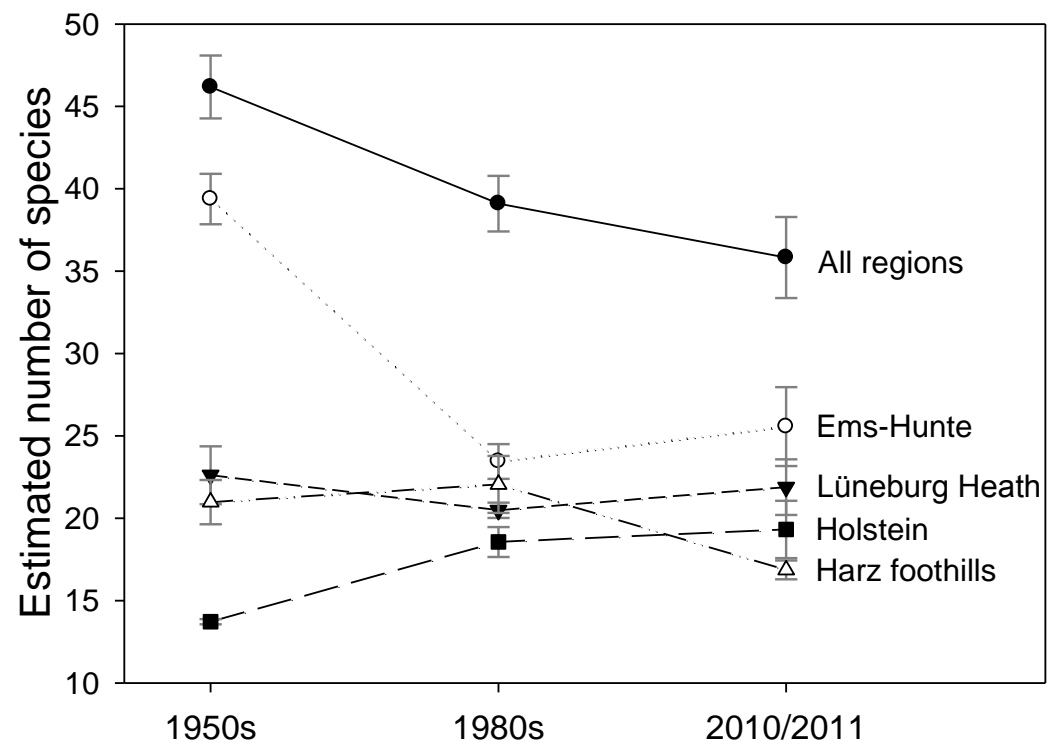

Figure 3.4 Estimated number of species for the 1950s, 1980s and 2010/2011, differentiated by regions. Mean values calculated from the species richness estimator indices ACE, ICE, Chao 1, Chao 2, Jackknife 1, Jackknife 2, Bootstrap and MMmeans for data set B (1980s) and subsets AєB (1950s) and $C \in B(2010 / 2011)$. Given are the means and the average standard deviation over all relevés in a region
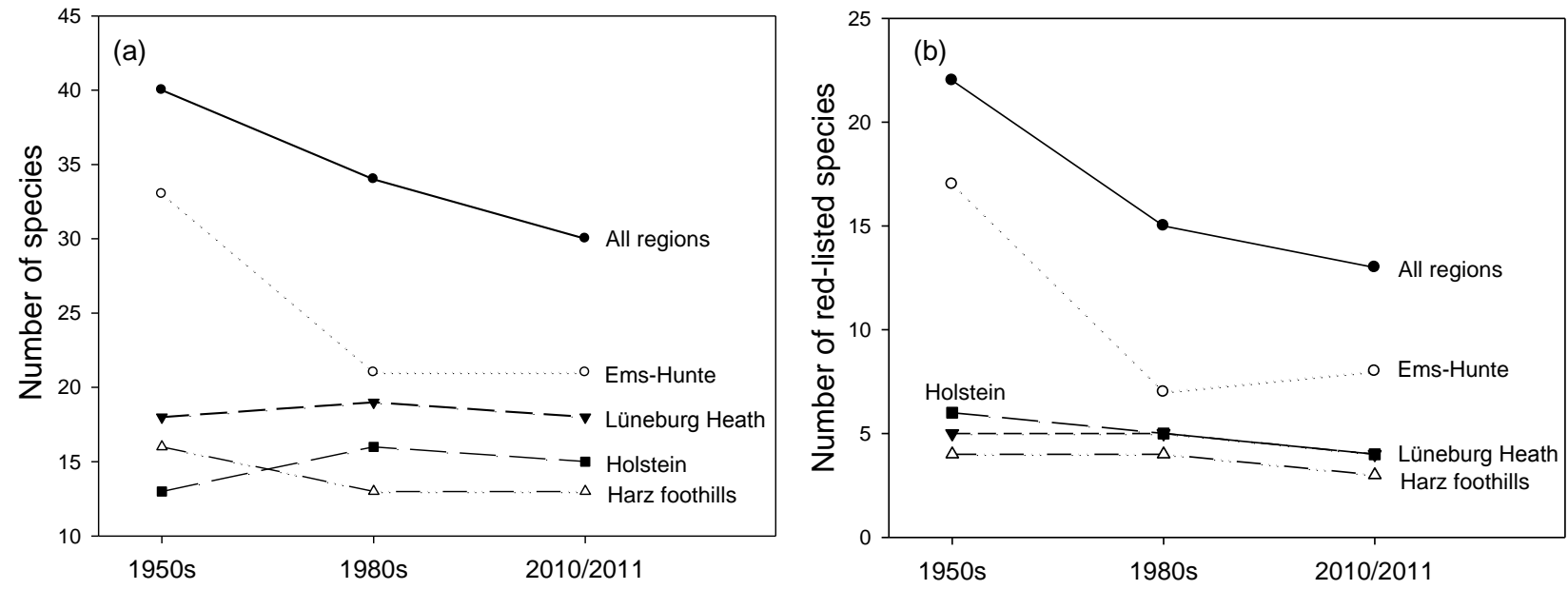

Figure 3.5 Total number of species present (a) and number of red-listed species present (b) in the 1950s, 1980s and in 2010/2011 (data sets AєB, B and C€B), differentiated by regions 


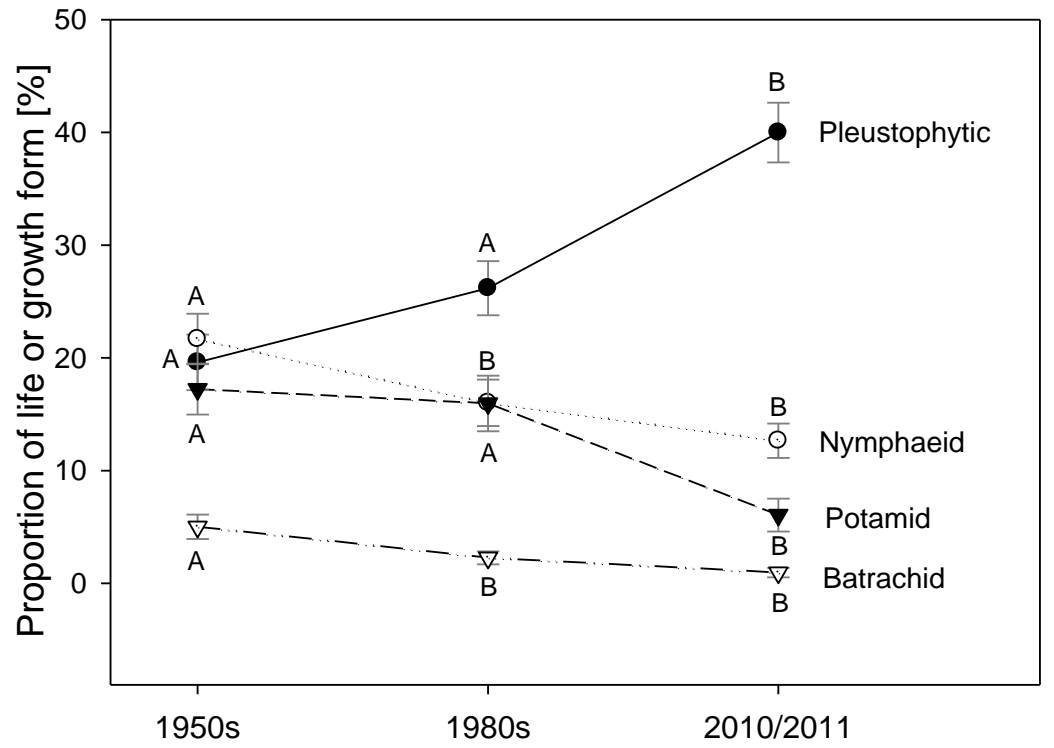

Figure 3.6 Proportions of pleustophytic (lemnid, ricciellid, ceratophyllid and hydrocharid) and rhizophytic (nymphaeid, potamid and batrachid) growth form types in the total number of species present in the 1950s, 1980s and 2010/2011 (means \pm SE of 100 relevés). Different letters indicate significant differences between the sampling dates
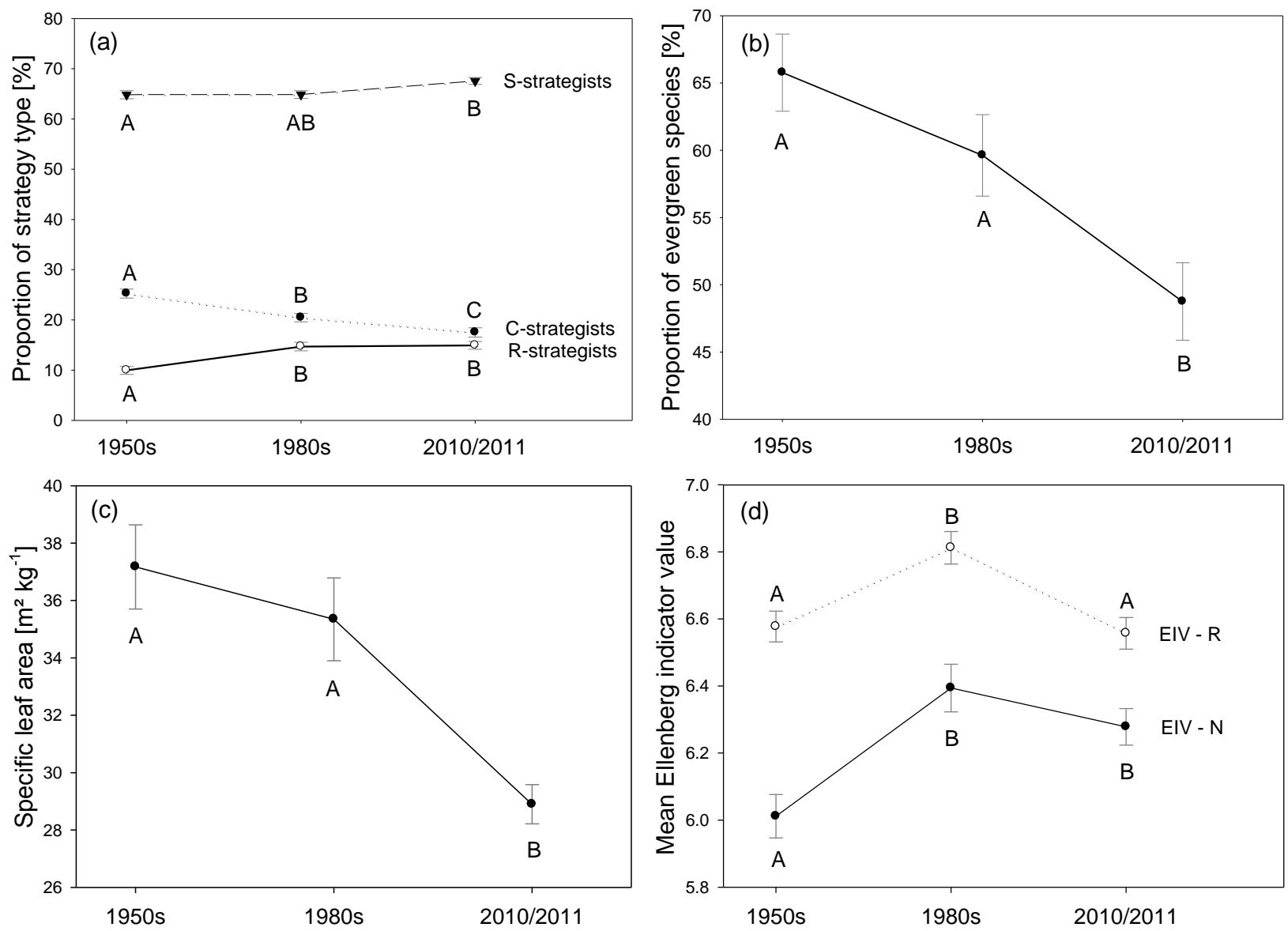

Figure 3.7 Mean relative proportion of (a) different plant strategy types, (b) evergreen species, (c) mean specific leaf area and (d) mean Ellenberg indicator values for nitrogen and soil reaction in the 1950 s, 1980s and 2010/2011. Means and standard errors are given ( $n=100$ relevés) 
The DCA analysis, based on 284 relevés of 100 locations that were sampled three times (in the 1950s, the 1980s and 2010/2011), revealed two main axes (eigenvalues 0.607 and 0.455 ) with the first axis sharing a close positive correlation with current velocity and a negative correlation with the EIVs for soil reaction $(\mathrm{pH})$ and temperature (Figure 3.8, Table 3.3 in the Appendix). Further, the relative abundance of competitors and of batrachid species correlated positively with axis 1 , while this axis showed negative correlations with the relative abundance of stress tolerators and pleustophytic species. The second axis correlated positively with time (i.e. the year of sampling) and the relative abundance of pleustophytes, and negatively with SLA, the number of red-listed species per relevé and the relative abundance of potamids.

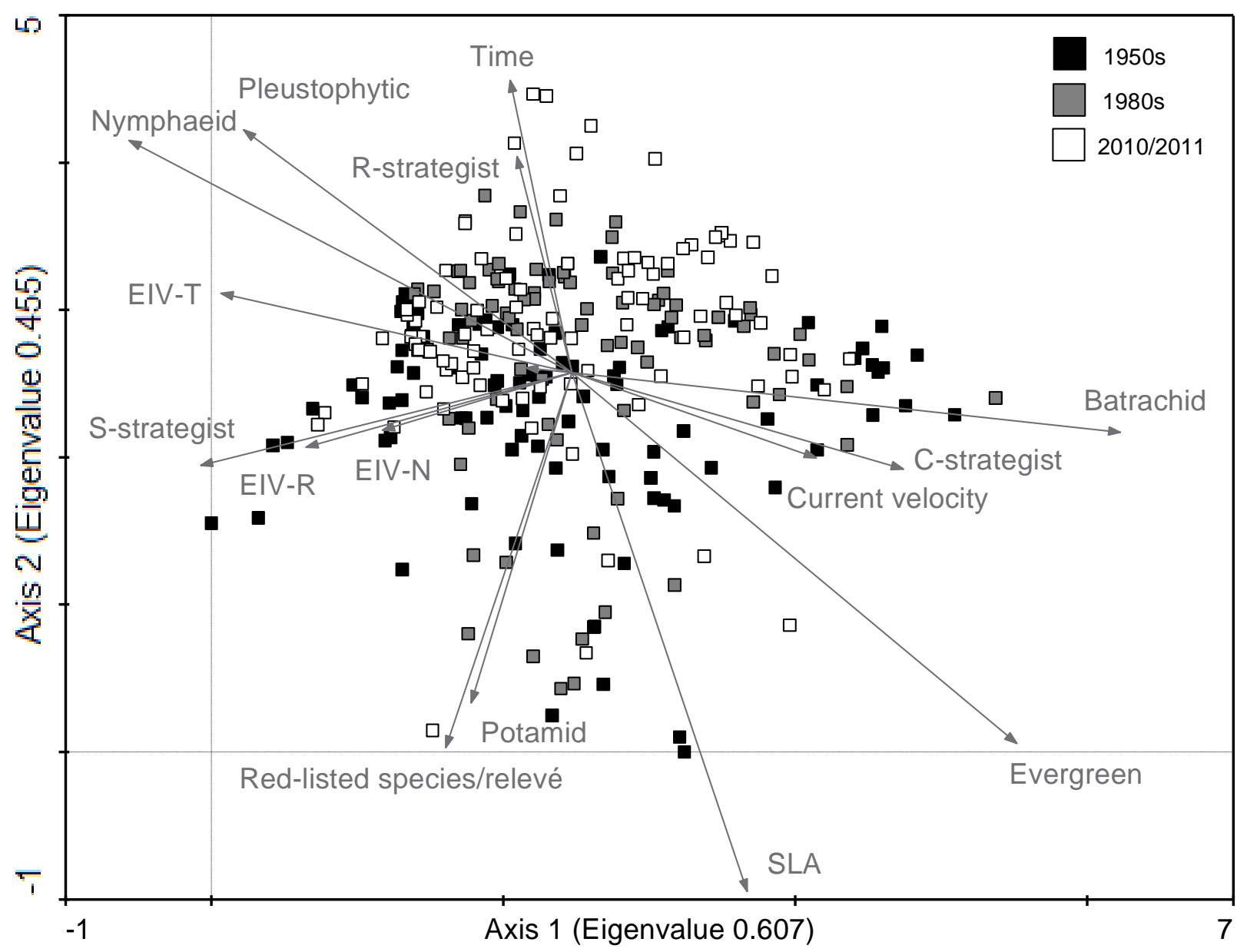

Figure 3.8 DCA graph based on 100 relevés from the 1950s resampled in the 1980s and 2010/2011 together with data (plot-level means) on the abundance of red-listed species, specific leaf area (SLA), proportion of evergreen species and plant life / growth forms, strategy type abundance, Ellenberg indicator values (EIVs) for nitrogen, temperature and soil reaction, and current velocity. For the ordination, species abundances were log-transformed and rare species were down-weighted; 15 relevés that did not contain macrophytes in recent time and one outlier were excluded 


\section{Discussion}

Our analysis of long-term vegetation change in 70 water courses of variable size, flow velocity and bedrock chemistry in an extended area of north-west Germany showed large reductions in the regional macrophyte species pool (-27.5\%) and in plot-level species richness $(-19.4 \%)$ during the past 60 years or so. The loss in the number of currently redlisted species $(-40.0 \%)$ in the regional species pool was even larger indicating that species with specific habitat requirements, which are usually more threatened by habitat change than generalist species, were indeed most vulnerable. Species loss was related to marked changes in macrophyte community composition with nearly half of the species present in the relevés in the 1950s either having disappeared until 2010/2011 or having been replaced by other species. The current macrophyte communities are not only species-poorer, but also consist of species with higher mechanical stress tolerance as indicated by a reduced specific leaf area and shorter leaf duration. A large increase in the relative importance of pleustophytic species at the expense of potamid and nymphaeid species reflects the profound alteration in community structure during the past 60 years.

A more detailed analysis showed that species loss and community change occurred more or less continuously during the past six decades and may continue if no measures to halt biodiversity erosion are taken. However, we found large differences in the temporal evolution of vegetation change among the four studied regions, which reflect local developments in hydro-engineering and, likely, also in agricultural intensification. The diversity decline in the macrophyte vegetation of north-west German lowland water courses over six decades has to be attributed to a variety of causes. Increased nutrient inputs with the intensification of agriculture since the 1950s have accelerated the eutrophication of most freshwater habitats (Ellenberg \& Leuschner 2010). The loss of species with preference for oligotrophic waters in our study area, such as Helosciadium inundatum, Juncus bulbosus, Luronium natans, Potamogeton filiformis, $P$. polygonifolius, Sparganium natans or Utricularia australis, is most likely a direct consequence of eutrophication. The increase in the mean Ellenberg indicator value for nitrogen from c. 6.0 to 6.4 between the 1950s and the 1980 s reflects increased nutrient availability in the water courses. Furthermore, the increase in the pleustophytic species Ceratophyllum demersum, Lemna spp. and Spirodela polyrhiza is also most likely a consequence of eutrophication. Apart from these species being competitive in exploiting nutrients, their free-floating growth forms allow them to remain on or close to the water surface, where they can escape light limitation in phytoplankton-rich, turbid water. Ceratophyllum demersum is able to relocate its biomass into the uppermost water layer (canopy forming) under turbid water conditions (Garniel 2008). Our results are in line with findings from streams in the Netherlands, where Mesters (1995) reported a shift from submerged to floating-leaved species over several decades, which he explained with 
increased water turbidity, because floating-leaved and emergent species do not depend on light transmission in clear water.

Potamal rivers are generally more affected by the influx of nutrient-enriched surface water from adjacent lands than rhithral water courses, because river water accumulates nutrients, while flowing through a catchment area with predominant agricultural land use. In fact, the changes in species composition were least pronounced in the groundwater-fed water courses of the Lüneburg Heath, which mostly have a rhithral character. While most rhithral streams are located in mountainous terrain, a number of running waters in the Lüneburg Heath region (region 2) are relatively cool in summer, due to groundwater inflow and thus also have rhithral characteristics, despite being located in the lowlands. In contrast, a comparatively high species turnover was found in the regions Ems-Hunte and eastern Holstein, where potamal rivers prevail in the intensively used agricultural landscape. With the embankment of the Dümmer lake and its main tributary Hunte river in 1953, the Dümmer lowlands, where the majority of sites in the Ems-Hunte region is located, have been transformed from a landscape dominated by swamps and fens to an area, where arable land is predominant and high nutrient inputs are affecting the wetland vegetation (Blüml et al. 2008). This regional development explains the huge loss of diversity in the Ems-Hunte region, where some effluents of the Dümmer lake have already reached the hypertrophic state (Niedersächsisches Landesamt für Ökologie 2001).

Since the 1980s, some improvement in the nutrient status of the running waters of northwest Germany has occurred. The slight decrease in the mean EIV for nitrogen, as observed since the 1980s, might reflect a decreased mineral nitrogen load in the studied river systems. The most important pathway of nitrogen into the water courses is runoff from agricultural lands, which accounts for about two thirds of total input. This diffuse fraction remained relatively stable, while inputs from point sources could be substantially reduced between 1983 and 2005 (German Federal Ministry for the Environment, Nature Conservation and Nuclear Safety \& German Federal Ministry of Food, Agriculture and Consumer Protection 2008). The input of phosphorus to surface waters has significantly decreased in the study area between 1980 and 1996, mainly as a consequence of reduced phosphorus contents in detergents and better sewage treatment (Schulz 1999). It appears that the vegetation is responding only slowly to these achievements.

In consideration of the previously discussed eutrophication effects, our finding of a decline in the floating-leaved growth forms nymphaeids and batrachids is somewhat perplexing. However, apart from eutrophication effects, the loss in structural diversity of river beds is another complex of factors responsible for the macrophyte diversity decline in rivers and streams in Central Europe (Wiegleb et al. 1991). Looking at the respective species in detail, it becomes obvious that the nymphaeids Luronium natans and Nymphaea alba and the 
batrachids Potamogeton gramineus and $P$. polygonifolius as well as a myriophyllid species that disappeared, Ranunculus circinatus, are bound to habitats where the water is constantly stagnant to slowly flowing (Casper \& Krausch 1980, 1981). Due to the anthropogenic reduction in structural diversity especially in lowland water courses, areas protected from the current, like inlets and shallow sections in the transition zone to floodplains, have become rare since the 1950s (Kaiser 1993, Rasper 2001). In 2000, 85\% of all river beds in the northern German federal state of Lower Saxony were in the state of having a substantially modified, unnatural morphological structure (Niedersächsisches Landesamt für Ökologie 2001). With the aim to speed-up runoff and increase landscape drainage, many river beds were deepened and broadened and the river course straightened, resulting in the loss of retention areas and in an overall decrease in mean current velocity in the potamal rivers. These melioration measures were supplemented by stabilization works on the river beds conducted in Lower Saxony particularly between the 1950s and the 1980s (Wasserverbandstag e.V. 2011). In regulated lowland rivers, straightened and steep banks are limiting macrophyte growth (Lorenz et al. 2012). In addition, most of the studied lowland water courses are continuously maintained and hence subject to regular disturbance (Federal Water Act of Germany 2009).

It is thus not surprising that stress-tolerant species make up the largest proportion of the macrophyte flora since the 1950s, which is interpreted as a sign that most water courses had lost their systems of dead channels and shallow side arms with its characteristic flora already decades ago. The proportional increase in the ruderal strategy type, which comprises species with a high reproduction rate and the ability of rapidly colonising open sediments, is a sign for irregular disturbance by maintenance works in the water courses (Trémolières 2004). The increase in species with a low specific leaf area may also indicate increased disturbance levels in recent time. In general, species with lower SLA and higher tissue density have a higher mechanical strength which facilitates survival in waters with higher flow velocity. We assume that in deepened and partly canalized water courses with temporarily high flow rates and a lack of retention areas, macrophytes with robust structure are favoured. We propose that the mean specific leaf area of a macrophyte community and its change over time may serve as a suitable indicator of the hydromechanical stress that is imposed on the plants as a consequence of river construction works.

Half of the 18 species that have disappeared in the study area between the 1950s and 2010/2011 belong to the genus Potamogeton. A severe loss of Potamogeton species was also observed in Danish lakes and streams over the last 100 years and was related to low remaining habitat diversity and frequent disturbance in our times (Sand-Jensen et al. 2000). Our study confirms these findings, as only the fast-growing, disturbance-tolerant pondweeds Potamogeton crispus, $P$. natans and $P$. pectinatus are still relatively common in north-west 
Germany. Nevertheless, the frequencies of these species have also decreased since the 1950 s to $60-30 \%$ of their former values. As most Potamogeton species are pollinated by water and wind, the decline in potamids resulted in a general decrease in hydrogamous and anemogamous species as well. Of the four species which have not been observed in the relevés before 2010/2011, Elodea nuttallii is a neophyte that was found in Germany for the first time near Münster (Westfalen) in 1953 and is now widespread (Starfinger \& Kowarik 2003). Potamogeton praelongus has always been a rare species in the study area (Casper \& Krausch 1980), while $P$. trichoides is a species considered vulnerable in Germany, where it has increased in the last decades (Haeupler \& Muer 2000, Ludwig et al. 2007). The latter is not a typical species of running waters; it is considered to be relatively abundant in ponds, ditches and canals throughout its native range in Europe, Asia and Africa (Allen 2011).

Mean winter temperature in Lower Saxony has risen by $1.9^{\circ} \mathrm{C}$ from 1950 to 2005 (Haberlandt et al. 2010). That summergreen species have experienced a relative increase, while evergreen species decreased, is probably mainly a consequence of increased disturbance intensity and not related to altered winter temperatures. Summergreens, overwintering with seeds or turions in the sediment, may be more tolerant to cold winters than evergreen macrophytes. Recent warming may have supported the arrival of Wolffia arrhiza, an indicator species for warm temperatures, in the study area in the last decades. Further warming may result in profound community change as is indicated by a modelling study for Finland, which predicts substantial changes in macrophyte community composition by 2050 with an increase in emergent macrophytes that may overgrow sensitive submerged macrophyte species (Alahuhta et al. 2011). Nevertheless, in the perspective of two to three decades, eutrophication and river-engineering are likely to represent more important threats to the river macrophyte vegetation of Central Europe than climate warming. Evidence in support of this conclusion is the observed increase in R-strategists and the decrease in mean SLA in our data, and the finding of Garniel (1999) that, after decades of intensive water course maintenance with machines, the vegetation in many running waters of Schleswig Holstein (northern Germany) mainly consists of mowing-tolerant species like Sparganium emersum, Nuphar lutea and Potamogeton pectinatus, which place their roots several decimetres deep in the sediment. 


\section{Conclusions}

Our resampling study documents the long-term change in the running water macrophyte vegetation of four regions that may be representative for large parts of the northern German diluvial lowlands. Both the decrease in the regional species pool and in plot-level diversity were dramatic with the consequence that most water courses are colonized nowadays by only species-poor, relatively uniform communities that contain a high proportion of species adapted to disturbance. While currently red-listed macrophytes were still relatively widespread in the 1950s, they are in many cases highly endangered in our times. This is, for example, the case for Myriophyllum alterniflorum, Isolepis fluitans (both endangered), Zannichellia palustris (near-threatened) and some magnopotamid species that have vanished in more than $50 \%$ of the sites visited, where they still occurred in the 1950s. The likely causes of the impoverishment are continued nutrient input from intensively managed agricultural land that caused the disappearance of oligo- and mesotraphent species and the restructuring of most river beds together with the continuous maintenance of water courses; these measures resulted in the loss of more stagnant stream and river habitats where stressintolerant species are able to persist. Thus, measures to reduce the nutrient load in rivers and to re-naturalize the flow regime in selected river sections are urgently needed in order to halt and reverse the catastrophic loss of phytodiversity in Central European lowland rivers. Both, biodiversity conservation and flood risk management, would profit from the creation of floodplain retention areas with a variety of stagnant freshwater habitats. The loss of most specialist species in the macrophyte flora largely devaluates this group in its role as an indicator of environmental quality in streams and rivers.

\section{Acknowledgments}

We are thankful to the Reinhold-Tüxen-Archive (Hannover) for granting access to historical vegetation relevés. We thank Uta Müller (Göttingen) for help in the field work. For help in taxonomical questions, we cordially thank Günther Dersch (Bovenden), who cytologically determined numerous samples of Callitriche, Sebastian Dittrich (Göttingen), who identified most of the bryophytes and Gerhard Wiegleb (Cottbus), who identified Potamogeton and Ranunculus specimen and gave comments on a former draft of the manuscript. Jürgen Homeier (Göttingen) and Karsten Wesche (Görlitz) gave valuable advice on statistical methods. Dieter Todeskino (Oldenburg) is acknowledged as he took part in the sampling in the 1980s. The study was undertaken within the BioChange project funded by the Ministry of Science and Culture of Lower Saxony. 


\section{References}

Alahuhta, J., J. Heino \& M. Luoto (2011): Climate change and the future distributions of aquatic macrophytes across boreal catchments. Journal of Biogeography 38: 383393.

Allen, D. (2011): Potamogeton trichoides. In: IUCN, 2012. IUCN Red List of Threatened Species. Version 2012.1, www.iucnredlist.org. [15.10.2012]

Bakker, J.D. (2008): Increasing the utility of Indicator Species Analysis. Journal of Applied Ecology 45: 1829-1835.

Blüml, V., F. Körner, U. Marxmeier, M. Richter \& A. Schönheim (2008): Entwicklung und aktuelle Situation der Verlandungsvegetation des Dümmers (Niedersachsen). Osnabrücker Naturwissenschaftliche Mitteilungen 33/34: 19-46.

Braun-Blanquet, J. (1964): Pflanzensoziologie, Grundzüge der Vegetationskunde. Springer, Wien: $865 \mathrm{p}$.

Bundesministerium für Umwelt, Naturschutz und Reaktorsicherheit, 2010. Umweltbericht 2010. Berlin: 233 p.

Casper, S.J. \& H.D. Krausch (1980): Pteridophyta und Anthophyta, 1.Teil: Lycopodiaceae bis Orchidaceae. In: H. Ettl, J. Gerloff \& H. Heynig (edts): Süsswasserflora von Mitteleuropa 23. Fischer, Stuttgart: $403 \mathrm{p}$.

Casper, S.J. \& H.D. Krausch (1981): Pteridophyta und Anthophyta, 2.Teil: Saururaceae bis Asteraceae. In: H. Ettl, J. Gerloff \& H. Heynig (edts): Süsswasserflora von Mitteleuropa 24. Fischer, Stuttgart: 539 p.

Daniel, H., I. Bernez \& J. Haury (2006): Relationships between macrophytic vegetation and physical features of river habitats: The need for a morphological approach. Hydrobiologia 570: 11-17.

Demars, B.O.L. \& M. Trémolières (2009): Aquatic macrophytes as bioindicators of carbon dioxide in groundwater fed rivers. Science of the Total Environment 407: 4752-4763.

Deutscher Wetterdienst (2012):

http://www.dwd.de/bvbw/appmanager/bvbw/dwdwwwDesktop?_nfpb=true\&_pageLab el=_dwdwww_klima_umwelt_klimadaten_deutschland\&T82002gsbDocumentPath=N avigation\%2FOeffentlichkeit\%2FKlima_Umwelt\%2FKlimadaten\%2Fkldaten_kosten frei\%2Fausgabe_monatswerte__node.html\%3F_nnn\%3Dtrue [28.03.2012]

Diekmann, M. (2003): Species indicator values as an important tool in applied plant ecology - a review. Basic and Applied Ecology 4: 493-506.

Dierschke, H. (1994): Pflanzensoziologie. Ulmer, Stuttgart: 683 p.

Dufrêne, M \& P. Legendre (1997): Species assemblages and indicator species: the need for a flexible asymmetrical approach. Ecological Monographs 67: 345-366.

Egertson, C.J., J.A. Kopaska \& J.A. Downing (2004): A century of change in macrophyte abundance and composition in response to agricultural eutrophication. Hydrobiologia 524: $145-156$.

Ellenberg, H., H.E. Weber, R. Düll, V. Wirth, W. Werner \& D. Paulissen (2001): Zeigerwerte von Pflanzen in Mitteleuropa. Scripta Geobotanica 18: 1-258.

Ellenberg, H. \& C. Leuschner (2010) Vegetation Mitteleuropas mit den Alpen. 6th ed. Ulmer, Stuttgart: $1334 \mathrm{p}$.

Federal Water Act of Germany (2009): Gesetz zur Neuregelung des Wasserrechts. Bundesgesetzblatt Teil 1, 51: 2585-2621.

Garniel, A. (1999): Schutzkonzept für gefährdete Wasserpflanzen der Fließgewässer und Gräben Schleswig-Holsteins, Teil B: Fließgewässer. Unpublished report on behalf of the Landesamt für Natur und Umwelt Schleswig-Holstein, Flintbek: 354 p. 
Garniel, A. (2008): Wasserpflanzen der Fließgewässer und Gräben - Informationen zum Verständnis ihrer Lebensstrategien als Grundlage für Erhaltungs- und Fördermaßnahmen in Schleswig-Holstein und Hamburg. Berichte des Botanischen Vereins zu Hamburg 24: 1-221.

German Federal Ministry for the Environment, Nature Conservation and Nuclear Safety \& German Federal Ministry of Food, Agriculture and Consumer Protection (2008): Nitrates report 2008. Joint report, Bonn: 73 p.

Grinberga, L. (2011): Macrophyte species composition in streams of Latvia under different flow and substrate conditions. Estonian Journal of Ecology 60: 194-208.

Haberlandt, U., A. Belli \& J. Hölscher (2010): Trends in beobachteten Zeitreihen von Temperatur und Niederschlag in Niedersachsen. Hydrologie und Wasserbewirtschaftung 54: 28-36.

Haeupler, H. \& T. Muer (2000): Bildatlas der Farn- und Blütenpflanzen Deutschlands. Ulmer, Stuttgart: $759 \mathrm{p}$.

Herr, W. \& G. Wiegleb (1984): Vegetationskundliche Untersuchungen zur biologischökologischen Situation Schleswig-Holsteinischer Fliessgewässer, Band 2: Tabellenband. Unpublished report on behalf of the Landesamt für Naturschutz und Landschaftspflege Schleswig-Holstein, Kiel.

Herr, W. (1987): Dynamik und Konstanz von Flora und Vegetation ausgewählter Fließgewässer Niedersachsens 1946 bis 1986. Unpublished report on behalf of the Niedersächsisches Landesverwaltungsamt, Fachbehörde für Naturschutz, Hannover.

Herr, W., G. Wiegleb \& D. Todeskino (1989): Veränderungen von Flora und Vegetation ausgewählter Fließgewässer Niedersachsens nach vierzig Jahren (1946/1986). Naturschutz und Landschaftspflege in Niedersachsachsen 18: 121-144.

Hill, M.O. \& H.G. Gauch (1980): Detrended correspondence analysis: an improved ordination technique. Vegetatio 42: 47-58.

Hill, M.O., D.B. Roy, J.O. Mountford \& R.G.H. Bunce (2000): Extending Ellenberg's indicator values to a new area: an algorithmic approach. Journal of Applied Ecology 37: 3-15.

Hilton, J., M. O'Hare, M.J. Bowes \& J.I. Jones (2006): How green is my river? A new paradigm of eutrophication in rivers. Science of the Total Environment 365: 66-83.

Holmes, N.T.H. \& B.A. Whitton (1977): The macrophytic vegetation of the river Tees in 1975: observed and predicted changes. Freshwater Biology 7: 43-60.

Hoppe, A. (2005) Das Reinhold-Tüxen-Archiv am Institut für Geobotanik der Universität Hannover. Tuexenia 25: 463-474.

Jansson, R., H. Laudon, E. Johansson \& C. Augspurger (2007): Importance of groundwater discharge for plant species number in riparian zones. Ecology 88: 131-139.

Jost, L. (2006): Entropy and diversity. Oikos 113: 363-375.

Kaiser, A. (1993): Zur Geschichte der Ems - Natur und Ausbau. Veröffentlichungen aus dem Kreisarchiv Gütersloh 1: 1-181.

Kleyer, M., R.M. Bekker, I.C. Knevel, J.P. Bakker, K. Thompson, M. Sonnenschein, P. Poschlod, J.M. Van Groenendael, L. Klimes, J. Klimesová, S. Klotz, G.M. Rusch, M. Hermy, D. Adriaens, G. Boedeltje, B. Bossuyt, A. Dannemann, P. Endels, L. Götzenberger, J.G. Hodgson, A-K. Jackel, I. Kühn, D. Kunzmann, W.A. Ozinga, C. Römermann, M. Stadler, J. Schlegelmilch, H.J. Steendam, O. Tackenberg, B. Wilmann, J.H.C. Cornelissen, O. Eriksson, E. Garnier \& B. Peco (2008): The LEDA traitbase: a database of life-history traits of the Northwest European flora. Journal of Ecology 96: 1266-1274. 
Klotz, S., I. Kühn \& W. Durka (2002): BiolFlor - Eine Datenbank zu biologisch-ökologischen Merkmalen der Gefäßpflanzen in Deutschland. Schriftenreihe für Vegetationskunde 38: 1-334.

Kohler, A. \& S. Schneider (2003): Macrophytes as bioindicators. Archiv für Hydrobiologie, Supplement 147: 17-31.

Korneck, D., M. Schnittler \& I. Vollmer (1996): Rote Liste der Farn-und Blütenpflanzen (Pteridophyta und Spermatophyta) Deutschlands. Schriftenreihe für Vegetationskunde 28: 21-187.

Kozlowski, G. \& S. Vallelian (2009): Eutrophication and endangered aquatic plants: an experimental study on Baldellia ranunculoides (L.) Parl. (Alismataceae). Hydrobiologia 635: 181-187.

Kuhar, U., T. Gregorc, M. Rencelj, N. Sraj-Krzic \& A. Gaberscik (2007): Distribution of macrophytes and condition of the physical environment of streams flowing through agricultural landscape in north-eastern Slovenia. Limnologica 37: 146-154.

Landolt, E., B. Bäumler, A. Erhardt, O. Hegg, F. Klötzli, W. Lämmler, M. Nobis, K. RudmannMaurer, F. Schweingruber, J.-P. Theurillat, E. Urmi, M. Vust \& T. Wohlgemuth (2010): Flora Indicativa - Ökologische Zeigerwerte und biologische Kennzeichen zur Flora der Schweiz und der Alpen. Haupt, Bern: 378 p.

Lennon, J.J., P. Koleff, J.J.D. Greenwood \& K.J. Gaston (2001): The geographical structure of British bird distributions: diversity, spatial turnover and scale. Journal of Animal Ecology 70: 966-979.

Londo, G. (1976): The decimal scale for relevés of permanent quadrats. Vegetatio 33: 6164.

Leps, J. \& P. Smilauer (2003): Multivariate analysis of ecological data using CANOCO. University Press, Cambridge: $269 \mathrm{p}$.

Lorenz, A.W., T. Korte, A. Sundermann, K. Januschke \& P. Haase (2012): Macrophytes respond to reach-scale river restorations. Journal of Applied Ecology 49: 202-212.

Ludwig, G., R. May \& C. Otto (2007): Verantwortlichkeit Deutschlands für die weltweite Erhaltung der Farn- und Blütenpflanzen - vorläufige Liste. BfN Skripten 220: 1-102.

Mäkirinta, U. (1978): Ein neues ökomorphologisches Lebensformen-System der aquatischen Makrophyten. Phytocoenologia 4: 446-470.

Marques, J.C., S.N. Nielsen, M.A. Pardal \& S.E. Jørgensen (2003): Impact of eutrophication and river management within a framework of ecosystem theories. Ecological Modelling 166: 147-168.

Mesters, C. (1995): Shifts in macrophyte species composition as a result of eutrophication and pollution in Dutch transboundary streams over the past decades. Journal of Aquatic Ecosystem Health 4: 295-305.

Niedersächsisches Landesamt für Ökologie (2001): Gewässergütebericht 2000. Oberirdische Gewässer 13: 1-40.

Phillips, G.L., D. Eminson \& B. Moss (1978): A mechanism to account for macrophyte decline in progressively eutrophicated freshwaters. Aquatic Botany 4: 103-126.

Pott, R. (1980): Die Wasser- und Sumpfvegetation eutropher Gewässer in der Westfälischen Bucht - pflanzensoziologische und hydrochemische Untersuchungen. Veröffentlichungen der Arbeitsgemeinschaft für Biologisch-Ökologische Landeserforschung 27, Münster: 147 p.

Rasper, M. (2001): Morphologische Fließgewässertypen in Niedersachsen - Leitbilder und Referenzgewässer. Niedersächsisches Landesamt für Ökologie, Hildesheim. 
Riis, T. \& K. Sand-Jensen (2001): Historical changes in species composition and richness accompanying perturbation and eutrophication of Danish lowland streams over 100 years. Freshwater Biology 46: 269-280.

Riis, T., K. Sand-Jensen \& O. Vestergaard (2000): Plant communities in lowland Danish streams: species composition and environmental factors. Aquatic Botany 66: 255272.

Robach, F., G. Thiébaut, M. Trémolières \& S. Muller (1996): A reference system for continental running waters: plant communities as bioindicators of increasing eutrophication in alkaline and acidic waters in north-east France. Hydrobiologia 340: 67-76.

Roll, H. (1939): Die Pflanzengesellschaften ostholsteinischer Fließgewässer - Limnologischsoziologische Studien. Archiv für Hydrobiologie 34: 159-305.

Sand-Jensen, K. \& J. Borum (1991): Interactions among phytoplankton, periphyton and macrophytes in temperate freshwaters and estuaries. Aquatic Botany 41: 137-175.

Sand-Jensen, K., T. Riis, O. Vestergaard \& S.O. Larsen (2000): Macrophyte decline in Danish lakes and streams over the past 100 years. Journal of Ecology 88: 10301040.

Schaumburg, J., C. Schranz, J. Foerster, A. Gutowski, G. Hofmann, P. Meilinger, S. Schneider \& U. Schmedtje (2004): Ecological classification of macrophytes and phytobenthos for rivers in Germany according to the Water Framework Directive. Limnologica 34: 283-301.

Schulz, F. (1999): Trendauswertung der stofflichen Belastung schleswig-holsteinischer Fließgewässer. In: Landesamt für Natur und Umwelt Schleswig-Holstein, Jahresbericht 1999, Flintbek: 59-65.

Schütz, W., U. Veit \& A. Kohler (2008): The aquatic vegetation of the Upper Danube river past and present. Large Rivers 162: 167-191.

Schwieger, F. (2002): Wasserpflanzen in Fließgewässern des niedersächsischen Elbegebietes. NLWK-Schriftenreihe 6, Lüneburg: $75 \mathrm{p}$.

Segal, S. (1968): Ein Einteilungsversuch der Wasserpflanzengesellschaften. In: Tüxen, R. (ed.): Pflanzensoziologische Systematik. Junk, The Hague: 191-218.

Smith, V.H., G.D. Tilman \& J.C. Nekola (1999): Eutrophication: impacts of excess nutrient inputs on freshwater, marine, and terrestrial ecosystems. Environmental Pollution 100: 179-196.

Starfinger, U. \& I. Kowarik (2003): Internet-Handbuch zum Erkennen und Bekämpfen invasiver Pflanzenarten, http://www.floraweb.de/neoflora/handbuch/elodeanuttallii.html [01.06.2012]

Trémolières, M. (2004): Plant response strategies to stress and disturbance: the case of aquatic plants. Journal of Biosciences 29: 461-470.

Vadineanu, A., S. Cristofor \& G. Ignat (1992): Phytoplankton and submerged macrophytes in the aquatic ecosystems of the Danube Delta during the last decade. Hydrobiologia 243/244: 141-146.

Wasserverbandstag e.V. (2011): Gewässerunterhaltung in Niedersachsen, Teil A, Rechtlichfachlicher Rahmen. Hannover: $64 \mathrm{p}$.

Weber-Oldecop, D.W. (1969): Wasserpflanzengesellschaften im östlichen Niedersachsen. Dissertation, University of Hannover: $172 \mathrm{p}$.

Weber-Oldecop, D.W. (1982): Die Vegetation der Kossau. Die Heimat 89: 122-125.

Whitton, B.A. \& M. Dalpra (1967): Floristic changes in the river Tees. Hydrobiologia 32: 545550. 
Whitton, B.A., P.N.G. Boulton, E.M. Clegg, J.J. Gemmell, G.G. Graham, R. Gustar \& T.P. Moorhouse (1998): Long-term changes in macrophytes of British rivers: 1. River Wear. The Science of the Total Environment 210/211: 411-426.

Wiegleb, G. (1981): Struktur, Verbreitung und Bewertung von Makrophytengesellschaften niedersächsischer Fließgewässer. Limnologica 13: 427-448.

Wiegleb, G. (1991): Die Lebens- und Wuchsformen der makrophytischen Wasserpflanzen und deren Beziehungen zu Ökologie, Verbreitung und Vergesellschaftung der Arten. Tuexenia 11: 135-147.

Wiegleb, G., H. Brux \& W. Herr (1991): Human impact on the ecological performance of Potamogeton species in northwestern Germany. Vegetatio 97: 161-172. 


\section{Chapter 4}

Sixty years of change in the macrophyte vegetation of north-west German running waters: a community- and landscape-level analysis

Kristina Steffen \& Christoph Leuschner

(submitted)
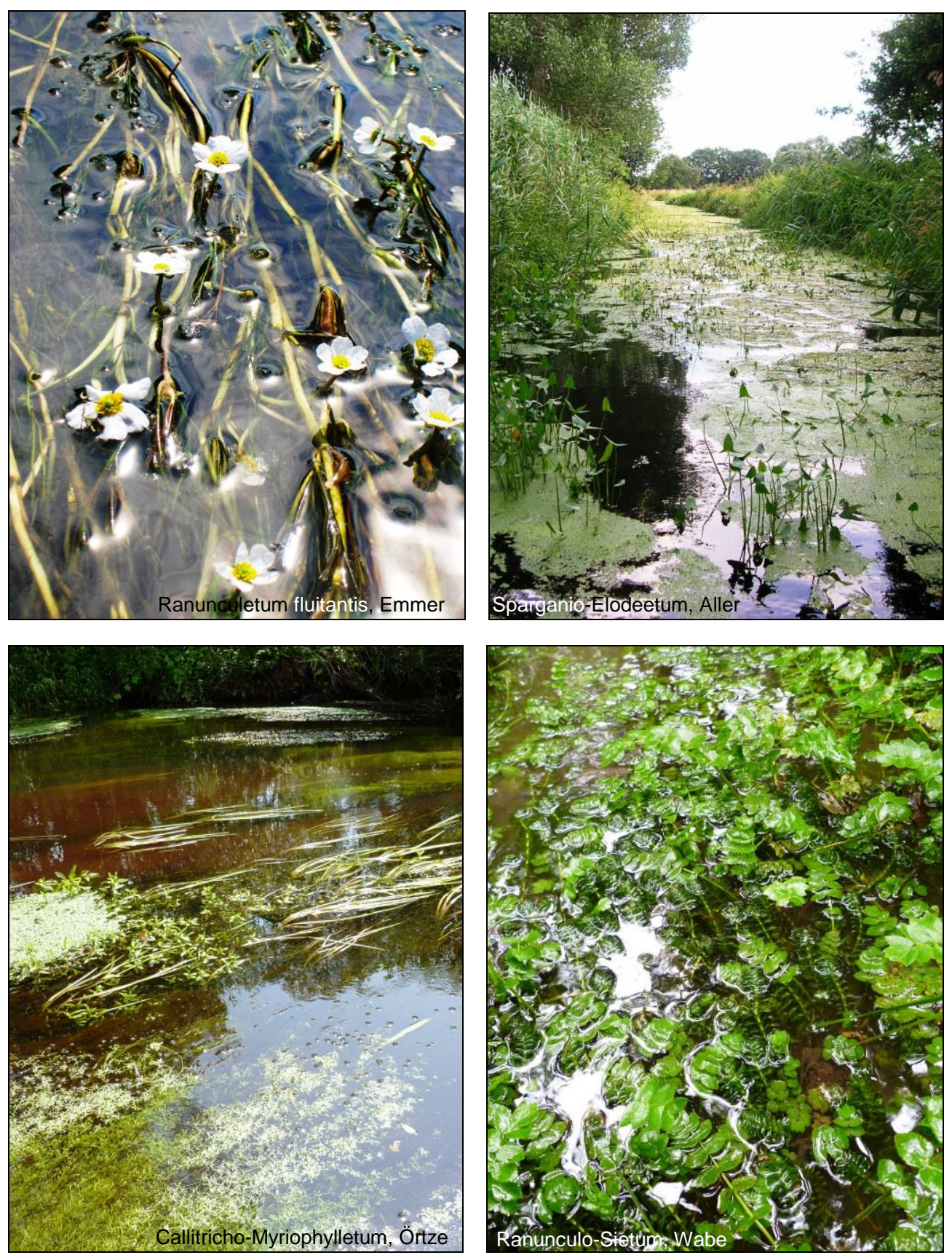


\section{Abstract}

Long-term change in the macrophyte assemblages of 70 streams and rivers in four regions of north-west Germany was examined with a semi-permanent plot design based on 337 historical vegetation relevés from the 1950s that were repeated in 2010/2011. Plant assemblages were classified with two alternative phytosociological approaches based on character species and/or dominant species. Over the $\sim 60$ years, the structure and composition of the vegetation changed profoundly in all four regions, even though local differences in vegetation dynamics existed. In general, stands assignable to the alliances Ranunculion (Batrachion) and Potamogetonion (assemblages dominated by submerged rooted plants) decreased greatly in frequency while Nymphaeion stands (dominated by floating-leaved rooted plants) increased. Communities weakly characterized by diagnostic species increased revealing losses of specialist taxa and homogenization of the assemblages; macrophyte community diversity at the landscape level decreased. Eutrophication, hydraulic engineering and regular maintenance works in the water courses are discussed as likely causes of the vegetation change. We conclude that decade-long human impact on river hydraulics and chemistry has significantly reduced both plot-level species richness and community diversity at the landscape level, profoundly altering the relative abundance of the assemblages.

Keywords: Ellenberg indicator values, eutrophication, phytosociological classification, reduction in community diversity, re-sampling study

\section{Introduction}

Streams and rivers and their macrophyte vegetation are among the ecosystems most severely affected by agricultural intensification in the world's industrialized regions (Malmqvist \& Rundle 2002, Ellenberg \& Leuschner 2010). In the lowlands of northern Central Europe, for example, the amounts of $\mathrm{N}$ and $\mathrm{P}$ fertilizers applied to arable fields and grasslands increased more than fourfold from the 1950s to the 1980s resulting in greatly increased nutrient inputs into the running waters and causing widespread eutrophication (Gelbrecht et al. 1996, Behrendt et al. 1999). In the course of floodplain melioration, many river beds were straightened and deepened to improve landscape drainage, and adjacent semi-aquatic habitats transformed to agricultural land. During the last four to six decades, the combined impact of nutrient addition and river engineering has fundamentally altered the structure of the macrophyte vegetation in the water courses of many Central European regions (Herr et al. 1989a, Fischer 1995, Whitton et al. 1998, Schütz et al. 2008). While longterm monitoring data of macrophyte vegetation change are very scarce, a number of re- 
sampling studies in Central, Western or Northern Europe documented reductions in plot-level diversity and impoverishment of the regional macrophyte species pool (e.g. Riis \& SandJensen 2001, Bouxin 2011, Steffen et al. 2013). For certain target species or genera with indicative value (such as Potamogeton), more detailed information does exist (Wiegleb et al. 1991, Preston 1995). However, the bulk of studies focused on relatively small areas with the consequence that a broader perspective of long-term change and impoverishment in the macrophyte vegetation has not yet emerged. The existing data demonstrate that change has not only reduced plot-level diversity in many macrophyte communities, but has also resulted in marked shifts in the species composition of the assemblages and in the relative abundance of the communities at the landscape scale. There is a need for cross-regional assessments of long-term community change in the macrophyte vegetation of running waters in Europe and elsewhere. This information could help to improve conservation programs for the endangered stream and river biota and it would allow conclusions on long-term habitat quality change in running waters beyond the insights gained from official monitoring programs that cover only a few hydro-chemical and -biological state parameters.

The community-based assessment of macrophyte vegetation change is hampered by the fact that vegetation classification in limnic habitats is more difficult than in most terrestrial habitats (Pearsall 1918, Haury \& Muller 2008). Problems identified include the considerable morphological plasticity of many species (Weber 1976), an often heterogeneous vegetation data basis with non-consistent plot sizes (Wiegleb 1981), the relatively low number of obligate hydrophytes in many communities, and the fact that many macrophyte species can form monospecific stands covering several square metres (Sculthorpe 1967, Best 1988). Consequently, a number of concepts of macrophyte community classification have been proposed, but consensus on the most suitable method does not exist. The approaches either adopt the traditional phytosociological association concept based on the identification of characteristic species (e.g. Roll 1939, Weber-Oldecop 1970, Preising et al. 1990, Pott 1995), use morphological growth forms for classification (Herr et al. 1989b, Dawson et al. 1999), apply numerical methods and similarity or dissimilarity indices for vegetation clustering (Paal et al. 2007), or combine two or more of these concepts (Berg et al. 2004, Chytrý 2011). There has been some discussion on the usefulness of applying phytosociological approaches to aquatic plant assemblages. In studies carried out in the tradition of the ZürichMontpellier school, the criterion of homogeneity often has led to the selection of relatively small relevé sizes (Braun-Blanquet 1964, Passarge 1982) resulting in nearly as many aquatic plant associations described as there are hydrophytic macrophyte species (Rennwald 2000). Since about the 1970s, the sampling of larger plots became more common and stretches of $50 \mathrm{~m}$ to several kilometres length along rivers of any size were investigated (e.g. Holmes \& Whitton 1977, Kohler 1978, Riis et al. 2000, van de Weyer 2001). Such large 
plots seem to be quite suitable for classification, because they are more likely to contain characteristic combinations of taxa and not only species-poor mono-dominant stands, but plots of large size will inevitably cover habitat mosaics due to gradients in water depth, current velocity, shading intensity and other factors, thus violating a basic assumption of the community concept.

In this study, which is complementary to an earlier study analysing species diversity changes in north-west German running waters (Steffen et al. 2013), we attempt to analyse the long-term change in the macrophyte assemblages of streams and rivers in north-west Germany over six decades with a focus on the community and landscape level. We conducted a re-sampling study in more than 300 semi-permanent vegetation plots in four regions covering a broad variety of stream and river habitats. The regions may be representative for large parts of the diluvial lowlands of northern Central Europe. By comparing the species composition and relative abundance of macrophyte assemblages in the regions for the 1950s and for 2010/2011, we addressed the following questions: (1) How has macrophyte community structure and the vegetation mosaic in streams and rivers changed as a consequence of agricultural intensification and water course management since the 1950s? (2) What do the individual developments of the macrophyte assemblages in the four studied regions tell us about the drivers of change? And (3) does a community and landscape level analysis increase our understanding of anthropogenic vegetation change beyond insights already gained from comparative plot-level diversity analyses?

\section{Materials and methods}

\section{Study area}

The 70 sampled streams and rivers are located in four regions of the north-west German Pleistocene lowlands (federal states of Lower Saxony, Schleswig-Holstein and North RhineWestphalia): (1) the Ems-Hunte moraine country with acid, base-poor moraine soils and bogs and (2) the Lüneburg Heath (including the Aller lowlands) with base-poor, sandy soils, both formed by the penultimate (Saale) Ice Age, (3) the northern Harz foothills (including some sites at the base of the Weser-Leine uplands) with fertile Pleistocene loess, and (4) the eastern Holstein moraine country with more base-rich young moraine soils of the last (Weichsel) Ice Age (Figure 4.1). The studied streams and rivers cover a broad range of water course types with small to medium size (1-40 m in diameter and 0.2-2 $\mathrm{m}$ in depth), current velocities between 0 and $50 \mathrm{~cm} \mathrm{~s}^{-1}$ and sandy to loamy sediments partly overlain by organic deposits or gravel. The catchments of all rivers are part of the cultural landscape of northwest Germany consisting of a mosaic of arable fields, pastures, meadows, forests and settlements. While the river sediments of the study regions 1 and 2 are base-poor and those of the regions 3 and 4 moderately base-rich, all rivers are receiving considerable nutrient 
loads from the adjacent intensively managed agricultural land in recent time. Due to the oceanic influence, the north-west German lowlands have a humid climate, characterized by relatively warm summers and relatively mild winters with short frost periods. Mean annual temperatures range around $9^{\circ} \mathrm{C}$, with the lowest mean temperature in January $\left(0.4^{\circ} \mathrm{C}\right.$ Braunschweig, Lower Saxony) and the highest mean temperature in July $\left(17.2^{\circ} \mathrm{C}\right.$ Hannover, Lower Saxony). The average annual precipitation ranges between $656 \mathrm{~mm} \mathrm{yr}^{-1}$ (Hannover) and $754 \mathrm{~mm} \mathrm{yr}^{-1}$ (Kiel, Schleswig-Holstein) (climate data taken from Deutscher Wetterdienst 2013).

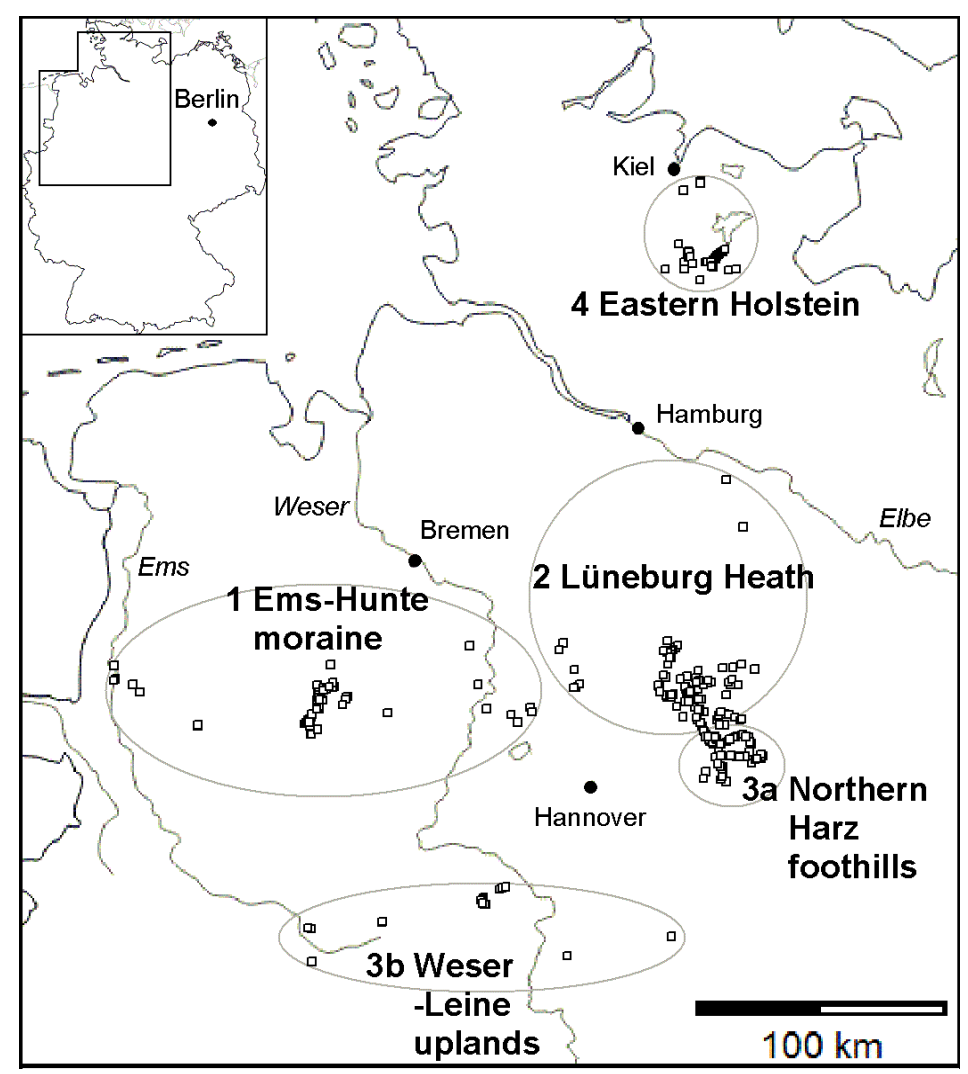

Figure 4.1 Location of the study sites (open squares) within four regions of NW Germany: region $1=$ Ems-Hunte moraine, region 2 = Lüneburg Heath (including the Aller lowlands), region $3=$ (a) northern Harz foothills and (b) base of the Weser-Leine uplands and region $4=$ eastern Holstein moraine

\section{Historical data}

We used 337 historical vegetation relevés taken from the Reinhold-Tüxen-Archiv, Hannover (Hoppe 2005; sampled by R. Alpers, R. Tüxen and A. von Hübschmann) and from the literature (Roll 1939, Weber-Oldecop 1969), dating back to between 1936 and 1969, which are referred to as $1950 \mathrm{~s}$ data. Plot sizes ranged between 1 and $100 \mathrm{~m}^{2}$. Since it has to be assumed that species identification in the genera Callitriche and Ranunculus was not always appropriate in former times, the taxa Callitriche cophocarpa, C. obtusangula, C. 
palustris, C. platycarpa and $C$. x vigens were summarized as $C$. palustris agg., while Ranunculus aquatilis and $R$. peltatus were summarized as $R$. aquatilis agg. The aggregates were used throughout the entire analysis and are referred to as species. As mentioned by Berg et al. (2004), it cannot necessarily be taken for granted that, in historical relevés, Lemnetea species were always noted during the documentation of a Potamogetonetea assemblage. However, in the case of the historical data used by us, lemnid species are frequently present in the Potamogetonetea relevés of all authors with the exception of the data of von Hübschmann (5 relevés of this author were included) suggesting that Lemnetea species were in most cases not ignored.

\section{Sampling design and field methods}

The historical vegetation relevés were repeated in the summers of 2010 and 2011 at the original sampling locations as indicated in the description or at the closest point, where vegetation was well developed. We sampled a plot size of $100 \mathrm{~m}^{2}$. Vegetation was inspected by means of wade trousers and a telescopic rake. Within a plot, the cover values of all plants rooting below the water surface were recorded. Additionally, the width and depth of the reach as well as the current velocity in the stream line (drift method, Weber-Oldecop 1969) were determined.

\section{Data analysis}

Seventy-nine species (all hydrophytes and those helophytes that are mentioned as character species in the literature) were included in the analyses. To relevés taken with the Braun-Blanquet cover class scores, we assigned the central numerical value of that class. We applied two alternative classification systems to the data set. First, the relevé material was classified by means of phytosociological character species following Preising et al. (1990), whose system was developed specifically for the freshwater plant assemblages of the north-west German lowlands, and after Schubert (2008) for bryophyte-dominated communities. In this approach, helophytes were only considered for classification in relevés that contained no hydrophytes. Since lemnid species are displaceable in running waters, relevés were only grouped as Lemnetea communities, if no rhizophytic hydrophytes were present.

Alternatively, the relevés were classified with the recently introduced phytosociological approach of Chytrý (2011) developed for the macrophyte vegetation of the Czech Republic. As a modification from this approach, we used lower cover threshold values for the assignment of relevés to an association: For reducing the proportion of relevés that were not assignable to defined associations, we adopted in the historical data set thresholds of $15 \%$ and $25 \%$, respectively, where $25 \%$ and $50 \%$ had been defined in the Czech system. 
In the 2010/2011 data, we set the cover threshold even to $2 \%$, because the recent plot size was on average larger than in the 1950s and we sought for a conservative assessment of community-level change by defining a low cut-off level which again reduced the number of non-assignable macrophyte stands. In the approach of Chytrý (2011), character species of the Batrachion associations are given a higher indicative value than those of the Potamogetonion associations, followed by those of Nymphaeion associations and finally by character species of the Lemnetea and Phragmito-Magno-Caricetea communities. The 56 historical and 128 recent relevés, that were not assignable after applying these rules, were grouped with the association to which the most similar relevé according to the Bray Curtis similarity index had been classified. The Bray Curtis index is defined as:

$S_{B C}=2 W /(A+B)$,

where $W$ is the sum of the lower cover values from each pair of shared species of the samples $A$ and $B, A$ is the sum of the cover values of all species in sample $A$, and $B$ is the sum of the cover values of all species in sample $B$.

Unweighted Ellenberg indicator values (EIVs) for temperature, soil reaction $(\mathrm{pH})$ and nutrients (Ellenberg et al. 2001) were calculated as means per plot and used as an indicator for environmental conditions. Differences between several groups of relevés were tested for significance $(p<0.05)$ with a Tukey post hoc test. A detrended correspondence analysis (DCA, Hill \& Gauch 1980) was conducted with the software Canoco 4.56 (Biometrics, Wageningen, NL). For every pair of historical and recent relevés at a given site, successional vectors translated to the origin (McCune et al. 2002) were calculated with the program PCOrd 5.1 (MjM Software, Gleneden Beach, US). The same was done for the summarized data for each of the 70 investigated running waters. The vector lengths were determined with the Pythagorean Theorem to analyze the vegetation change over time at the regional level and in relation to environmental and hydrographic factors. The factors were correlated with the DCA axes in a post hoc manner. Spearman rank correlation was used, since the axes scores and successional vector lengths were not normally distributed; the significance levels for the correlations are not based on a permutation test, but are given to indicate the strengths of the relationships. For placing the communities in a two-dimensional niche space defined by current velocity and the EIV for nutrients, the minima and maxima of the two variables observed in the respective vegetation unit were used. The average similarity $\left(\mathrm{S}_{\mathrm{BC}}\right)$ between the historical and recent assemblages was calculated from all possible pairs of data summarized per river (species lists and numbers of occurrences) and compared with a Wilcoxon test. All statistical tests were carried out with the software SPSS 15 (SPSS Inc., Chicago, USA). 


\section{Results}

Vegetation change in river macrophyte assemblages over 60 years as revealed by the classification after Preising et al. (1990)

In total, 79 taxa of higher plants and mosses (60 hydro- or amphiphytic and 19 helophytic taxa) were recorded in the streams and rivers of the four study regions (Tables 4.1a and 4.1b in the Appendix). Applying the phytosociological classification system of Preising et al. (1990), ninety-five percent of the relevés taken in historical time or in 2010/2011 could be assigned to phytosociological units within the class Potamogetonetea, which contains all submerged or floating-leaved, rooted vascular plant vegetation types of European fresh waters (Table 4.2). About five percent of the relevés in 2010/2011 (none in the 1950s) referred to the class Lemnetea, i.e. free-floating macrophyte carpets at the surface without presence of rhizophytic hydrophytes. Within the principal macrophyte class Potamogetonetea, all three orders recognized by Preising et al. (1990) were represented by relevés. The most widespread assemblage at the association level was in the 1950s the Callitricho-Myriophylletum (in the alliance Ranunculion fluitantis and the order CallitrichoBatrachietalia) with $~ 28 \%$ of all relevés, followed by the Potamogetonetum lucentis (in the alliance Potamogetonion lucentis and the order Potamogetonetalia; $12 \%)$. In historical time, $18 \%$ of the relevés referred to assemblages characterized by pondweeds (order Potamogetonetalia) and $15 \%$ to relevés characterized by floating-leaved, rooted Nymphaeetalia assemblages. About six decades later, the relative frequency of the most widespread association, the Callitricho-Myriophylletum, has greatly decreased (-32\%). Large decreases were also recorded for most of the pondweed assemblages, notably the formerly widespread Potamogetonetum lucentis $(-78 \%)$ and the assemblages in the order Potamogetonetalia in general $(-58 \%)$. The number of relevés assigned to the Potamogetonetum lucentis remained constant over time in the Lüneburg Heath (region 2), but decreased greatly in the Ems-Hunte and eastern Holstein regions, where this community formerly occurred at 22 and 14 sites, respectively, and decreased to three sites each in 2010. Marked decreases were also found in the once more frequent Ranunculion fluitantis assemblage Ranunculo-Sietum (-47\%).

In contrast, more frequently occurring in 2010/2011 were assemblages of the Nymphaeetalia order (+44\%) with the association Sparganio-Elodeetum (+46\%). The Myriophyllo-Nupharetum and the Sparganio-Elodeetum stands occur only in streams with low current velocities (Figure 4.2a) and were mainly restricted to region 1 (Ems-Hunte moraine) in both surveys. Water lens carpets (class Lemnetea) apparently occurred more frequently in running waters in 2010/2011 than in the 1950s, with fragments of the alliances Lemnion gibbae and Lemnion trisulcae found in region 4 (eastern Holstein), where rivers often flow through lakes with stagnant waters. Two moss-dominated relevés originating from 
region 3 (northern Harz foothills) from 2010/2011 were assigned to the class Fontinalietea, a few helophytic assemblages to the class Phragmitetea (reed vegetation). Among the each 337 relevés taken in the two surveys, the number of relevés assignable to the association level decreased by a fourth from 198 (59\% of the total) in the 1950s to only $145(43 \%)$ in 2010/2011, indicating that more than half of the recent relevés lacked diagnostic taxa for the association level.
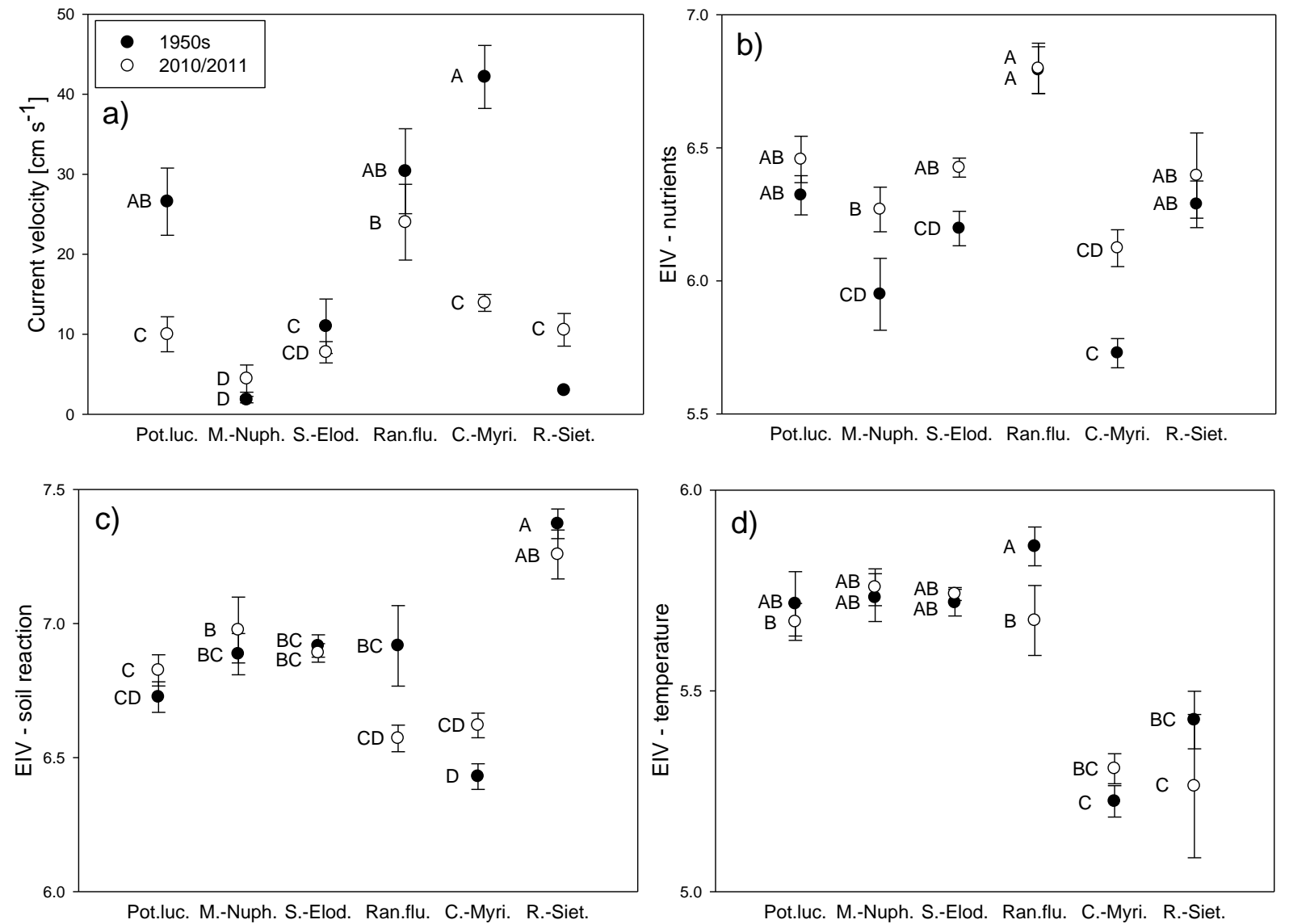

Figure 4.2 (a) Current velocity and mean Ellenberg indicator values for (b) nutrients, (c) soil reaction and (d) temperature in six important macrophyte associations in the 1950s and 2010/2011 (198 relevés from the 1950s and 145 relevés from 2010/2011; given are means \pm SE). Different letters indicate significant differences between the periods. Pot.luc. $=$ Potamogetonetum lucentis, M.-Nuph. = Myriophyllo-Nupharetum. S.-Elod. = Sparganio-Elodeetum, Ran.flu. = Ranunculetum fluitantis, C.Myri. = Callitricho-Myriophylletum, R.-Siet. = Ranunculo-Sietum. Only one Ranunculo-Sietum relevé from the 1950s contained information about current velocity 
Table 4.2 Number of relevés assignable in the 1950s or in 2010/2011 to macrophyte classes, orders, alliances or associations according to the phytosociological system after Preising et al. (1990). At the order, alliance and association level, only syntaxa of the most widespread class Potamogetonetea are listed. In the two survey periods, 337 and 327 relevés were analyzed. The change between the 1950s and $2010 / 2011$ is expressed in percent loss or gain in frequency

\begin{tabular}{lrrr}
\hline & $\begin{array}{c}\text { No. of relevés } \\
\text { in the 1950s }\end{array}$ & $\begin{array}{r}\text { No. of relevés } \\
\text { in 2010/2011 }\end{array}$ & Change [\%] \\
\hline Lemnetea & - & 18 & \\
Potamogetonetea & 336 & 305 & -9.2 \\
Phragmitetea & 1 & 7 & +85.7 \\
Platyhypnidio-Fontinalietea antipyreticae & - & 2 & \\
No macrophyte vegetation present & - & 5 & \\
\hline Orders in Potamogetonetea & & & \\
\hline Potamogetonetalia & 59 & 25 & -57.6 \\
Nymphaeetalia & 52 & 92 & +43.5 \\
Callitricho-Batrachietalia & 219 & 183 & -16.4 \\
\hline Alliances in Potamogetonetea & & & \\
\hline Potamogetonion graminei & & - & \\
Potamogetonion lucentis & 1 & 11 & -73.2 \\
Potamogetonion pusilli & 16 & 10 & -37.5 \\
Nymphaeion albae & 40 & 75 & +46.7 \\
Hydrocharition & 2 & - & \\
Ranunculion fluitantis & 212 & 171 & -19.3 \\
\hline Associations in Potamogetonetea & & & \\
\hline Potamogetonetum lucentis & 40 & 9 & -77.5 \\
Myriophyllo-Nupharetum luteae & 12 & 11 & -8.3 \\
Sparganio-Elodeetum & 24 & 44 & +45.5 \\
Ranunculetum fluitantis & 10 & 7 & -30.0 \\
Callitricho-Myriophylletum alterniflori & 95 & 65 & -31.6 \\
Ranunculo-Sietum erecti-submersi & 17 & 9 & -47.1 \\
\hline Assignable to association level & 198 & 145 & -26.8 \\
Assignable only to alliance level & 115 & 135 & +14.8 \\
Assignable only to order level & -47 & +61.7 \\
Assignable only to class level & 5 & -16.7 \\
\hline
\end{tabular}

\section{Vegetation change as revealed by the classification system after Chytrý (2011)}

When applying the classification system of Chytrý (2011), nearly all 674 relevés could be assigned to one of 30 associations of this system (including the Elodea nuttallii dominance stand). Assignment was not possible for five relevés that referred to river sections devoid of macrophyte vegetation in 2010/2011. The Czech system does not contain the level of orders, but a rough congruence between Preising's Batrachietalia, Potamogetonetalia and Nymphaeetalia orders with Chytrý's Batrachion, Potamogetonion and Nymphaeion alliances does exist. Analysis of community change based on the Chytrý (2011) classification indicated that only a few historical Batrachion and Nymphaeion stands were replaced by Potamogetonion stands in 2010/2011, while many of the former Potamogetonion stands 
changed into Lemnetea and Nymphaeion stands in recent time (Table 4.3). The proportional increase of macrophyte communities assignable to the class Lemnetea and the alliance Nymphaeion, being typical for potamal water courses, as found in the Preising approach was confirmed with the Chytrý approach (Figure 4.3). Especially in the regions 1 (Ems-Hunte) and 4 (Holstein), communities adapted to very low current velocities increased in the rivers and streams. Dominance stands of Elodea nuttallii were exclusively observed in the regions 1 and 2.

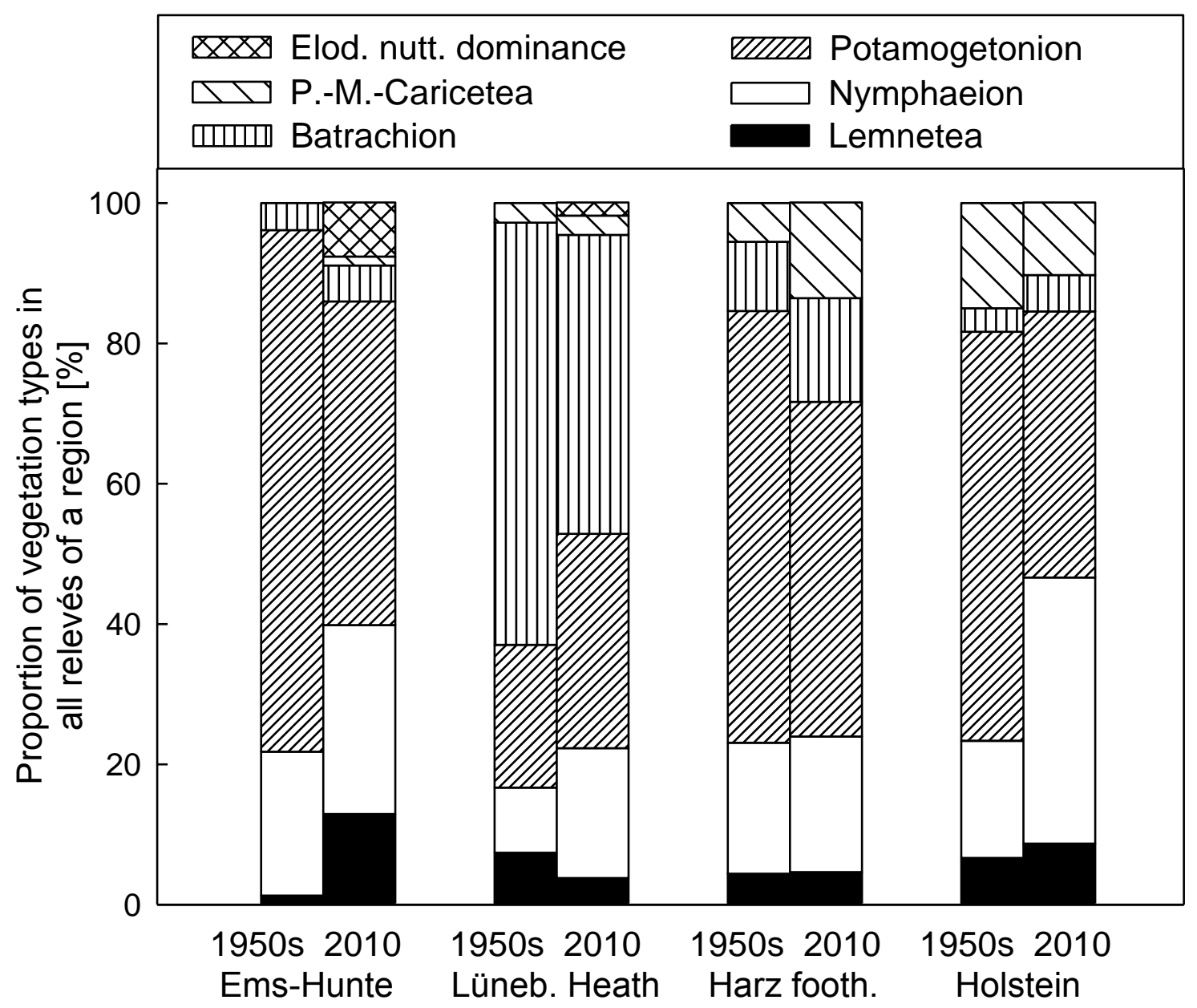

Figure 4.3 Proportion of different synsystematic groups of macrophyte assemblages (classification after Chytrý 2011) in the total number of relevés of the four studied regions in the 1950s and 2010/2011 (78 semi-permanent plots in region 1, 108 in region 2, 91 in region 3 and 60 in region 4) 
Table 4.3 Temporal change in the macrophyte vegetation stands as mirrored in the system of Chytrý (2011) with the assignment of the relevés to associations in the 1950s (rows) and in 2010/2011 (columns) (associations 1 to 31 with $1=$ Lemnetum minoris, $2=$ Lemnetum gibbae, $3=$ LemnoSpirodeletum polyrhizae, $4=$ Lemnetum trisulcae, $5=$ Lemno-Utricularietum, $6=$ Ceratophylletum demersi, $7=$ Hydrocharitetum morsus ranae, 8= Potamogetonetum crispi, 9= Potamogetonetum natantis, 10= Potamogetonetum pectinati, 11= Potamogetonetum pusilli, 12= Elodeetum canadensis, 13= Potamo pectinati-Myriophylletum spicati, 14= Groenlandietum densae, 15= Potamogetonetum tenuifolii, 16= Potamogetonetum zizii, 17= Potamogetonetum friesii, 18= Potamogetonetum lucentis, $19=$ Potamogetonetum denso-nodosi, $20=$ Potamogetonetum crispo-obtusifolii, $21=$ Potamogetonetum perfoliati, 22= Scirpo fluitantis-Potamogetonetum polygonifolii, 23= Parvo-Potamo-Zannichellietum pedicellatae, 24= Nymphaeo albae-Nupharetum luteae, 25= Nymphaeetum albae, 26= Ranunculetum fluitantis, 27= Callitricho hamulatae-Ranunculetum fluitantis, 28= Myriophylletum alterniflori, 29= Glycerio-Sparganietum, 30= Beruletum erectae, $31=$ Elodea nuttallii dominance stands and no. veg.= vegetation-free). The numbers give the number of assigned stands (relevés). Numbers in grey fields refer to vegetation stands assigned to the same association in the 1950s and in 2010/2011

\begin{tabular}{|c|c|c|c|c|c|c|c|c|c|c|c|c|c|c|c|c|c|c|c|c|c|c|c|c|c|c|c|}
\hline & & & em & net & & & & & & Pota & amo & get & oni & & & & & & $\begin{array}{l}\text { Nym } \\
\text { ohae } \\
\text { ion }\end{array}$ & & $\begin{array}{l}\text { Bat } \\
\text { chi }\end{array}$ & $\begin{array}{l}\text { tra- } \\
\text { on }\end{array}$ & & $\begin{array}{l}\text {-M.- } \\
\text { ari- } \\
\text { tea }\end{array}$ & & & \\
\hline $\begin{array}{l}\text { Asso- } \\
\text { ciation }\end{array}$ & 1 & 3 & 3 & 4 & 5 & 6 & 8 & 9 & 10 & 11 & 12 & 13 & & 815 & & 20 & 21 & 23 & 24 & 26 & 27 & 28 & 29 & 30 & 31 & $\begin{array}{l}\text { no } \\
\text { veg. }\end{array}$ & $\Sigma$ \\
\hline 1 & & & & & & & & 1 & & & & & 1 & & & & & 1 & 2 & 1 & 3 & & & 1 & & & 10 \\
\hline 2 & & & & & & & & & & & & 1 & & & & & & & 1 & & & & & & & & 2 \\
\hline 3 & & & & & & & & 1 & & & & & & & & & & & & & & & & & & & 1 \\
\hline 4 & & & & & & & & & & & & & & & & & & & & & & & 1 & & & & 1 \\
\hline 5 & & & & & 1 & & & & & & & & & & & & & & & & & & & & & & 1 \\
\hline 7 & & & & & & & & & & & & & & & & & & & 1 & 1 & & & & & & & 2 \\
\hline 8 & & & & & 1 & 1 & 1 & & 1 & & & 2 & 1 & & & & & & 2 & & 1 & & & & & & 10 \\
\hline 9 & & & & & & & & 6 & 4 & 2 & 5 & 3 & & & & & 1 & & 7 & & 1 & & & & & & 29 \\
\hline 10 & 1 & & & & & & & 2 & 9 & & & 1 & & & & & 3 & & 4 & 1 & & & & & 1 & & 22 \\
\hline 11 & & & & & & & 1 & 1 & & & & 3 & & & & & & 1 & 3 & & & & & & & & 9 \\
\hline 12 & 2 & & & & & & 1 & & & & 2 & & & & & & 3 & & 7 & & & 2 & 2 & & 1 & 1 & 21 \\
\hline 13 & & & & & & & & 2 & 1 & & & 1 & & & & & & & 1 & & & & & & & & 5 \\
\hline 14 & & & & & & & & & & & & & & & & & & & 1 & & & & & 1 & & & 2 \\
\hline 15 & & & & & & & & & & & & & & & & 1 & & & & & 1 & & & & & & 2 \\
\hline 16 & & & & & & & & & & & & & & & & & & & 1 & & & & & & & & 1 \\
\hline 17 & 1 & & & & & & & & & & & 2 & & & & & & & & & & & & & & 1 & 4 \\
\hline 18 & 3 & & & & 1 & & 2 & & & & 3 & 1 & 4 & 13 & & & 2 & & 9 & & & & & & 1 & 1 & 30 \\
\hline 19 & & & & & & & & & & & & & & & & & 1 & & & & & & 1 & & & & 2 \\
\hline 20 & & & & & & & & & & & & & & & & & 1 & & & & & & & & & & 1 \\
\hline 21 & & 1 & 1 & & & & & 1 & 2 & & 2 & & 2 & & & & 1 & & 5 & 1 & 1 & & & & 1 & & 17 \\
\hline 22 & & & & & & & & & & & & & & & & & & & 1 & & & & & & & & 1 \\
\hline 23 & 1 & & & & & & 1 & & & & & & & & & & & 2 & 2 & & & 2 & & 7 & & & 15 \\
\hline 24 & 1 & 2 & 2 & 1 & & 3 & 1 & 2 & 2 & 1 & 1 & 5 & 3 & & & & & 1 & 20 & 1 & 2 & & 1 & 1 & 2 & 2 & 52 \\
\hline 25 & & & & & & & & & & & & & & & & & & & 1 & & & & & & & & 1 \\
\hline 26 & & & & & & & 1 & & 1 & 1 & & & & & & & & 1 & 2 & 5 & & & & 1 & & & 12 \\
\hline 27 & 1 & 2 & 2 & & & & & 2 & 1 & & 3 & 2 & 1 & & & & & 2 & 4 & 5 & 9 & 14 & 2 & & 2 & & 50 \\
\hline 28 & & & & & & & & 1 & & & 2 & 1 & & & & & & & 2 & & 2 & 8 & 1 & & & & 17 \\
\hline 29 & & & & & & & & & & & & & & & & & & & & & & 1 & & & & & 1 \\
\hline 30 & & & & & & & 1 & & 1 & & & & & & & & 3 & & 4 & 1 & & 3 & 2 & 1 & & & 16 \\
\hline$\Sigma$ & 10 & ) & 5 & 1 & 3 & 4 & 9 & 19 & 22 & 4 & 10 & 32 & 21 & 23 & & 1 & 15 & 8 & 80 & 16 & 20 & 30 & 10 & 12 & 8 & 5 & 337 \\
\hline
\end{tabular}




\section{Environmental change at the community level since the 1950s}

The detrended correspondence analysis of all relevés assignable to the association level in Preising's system showed a relatively clear division between the communities of potamal, more gently flowing water course reaches, which represent units of the Nymphaeion albae and Potamogetonion lucentis alliances, and those of smaller water course reaches with higher current velocities, which were assigned to the Ranunculion fluitantis alliance (Figure 4.4). While the first DCA axis revealed a strong negative correlation with various abiotic site factors, notably water depth and the EIVs for temperature, soil reaction and nutrients, and a positive relation to current velocity, the second axis correlated positively with time (sampling years) and negatively with current velocity (Table 4.4). Analysis of environmental change over time in waters colonized by the six most frequent macrophyte associations showed that in two of the six communities (Myriophyllo-Nupharetum and Sparganio-Elodeetum), the mean EIV for nutrients was significantly higher in 2010/2011 than in the 1950s (non-significant trend also in the Callitricho-Myriophylletum). In the Ranunculetum fluitantis, the mean EIV for nutrients was high in both periods (c. 6.7; Figure 4.2b). No significant change over time was found for the mean EIV for soil reaction; the Ranunculo-Sietum (only recorded in region 3: Harz foothills) had a particularly high mean EIV for soil reaction in both periods (Figure 4.2c). Interestingly, we found in none of the six assemblages a significant increase in the EIV for temperature over the six decades (Figure $4.2 \mathrm{~d}$ ), even though the communities differ considerably in their apparent thermal requirements. The Ranunculetum fluitantis showed even a significant decrease in EIV-T between the 1950s and 2010/2011. The current velocity measurements indicate a broad range of characteristic flow ranges for the six assemblages with nearly stagnant waters characterizing the sites of the Myriophyllo-Nupharetum and highest velocities found at the sites of the Ranunculetum fluitantis and Callitricho-Myriophylletum (Figure 4.2a). At the sites of the Potamogetonetum lucentis and Callitricho-Myriophylletum, current velocity has apparently decreased since the 1950s. Linking the pairs of plots of a given site with successional vectors in the ordination space revealed an overall change among the communities in the negative direction of DCA axis 1 . This axis correlated negatively with river width (reach size) and the EIVs for nutrients and temperature (Figure 4.5, Table 4.5 in the Appendix), thus pointing to general increases in nutrient availability, temperature and river width over the 60 years. When grouped by region, the successional vectors of the region 2 (Lüneburg Heath) correlated positively with increasing EIVs for temperature, soil reaction and nutrients and that of region 4 (eastern Holstein) with river width and depth (Table 4.6). Summarizing the vegetation change observed in each of the 70 rivers confirmed a general path of vegetation succession over the 60 years, which followed rising nutrient availabilities and an increase in water course size reflecting river engineering works (Figure 4.6, Table 4.7 
in the Appendix and Table 4.8). The average similarity between the macrophyte assemblages of all possible pairs of rivers was significantly $(p<0.001)$ lower in the historical $\left(\mathrm{S}_{\mathrm{BC}}=0.22\right)$ than in the recent $(0.25)$ vegetation data. Figure 4.7 suggests that the historical macrophyte assemblages seem to have occurred under a wider range of nutrient availabilities and current velocities than the recent assemblages.
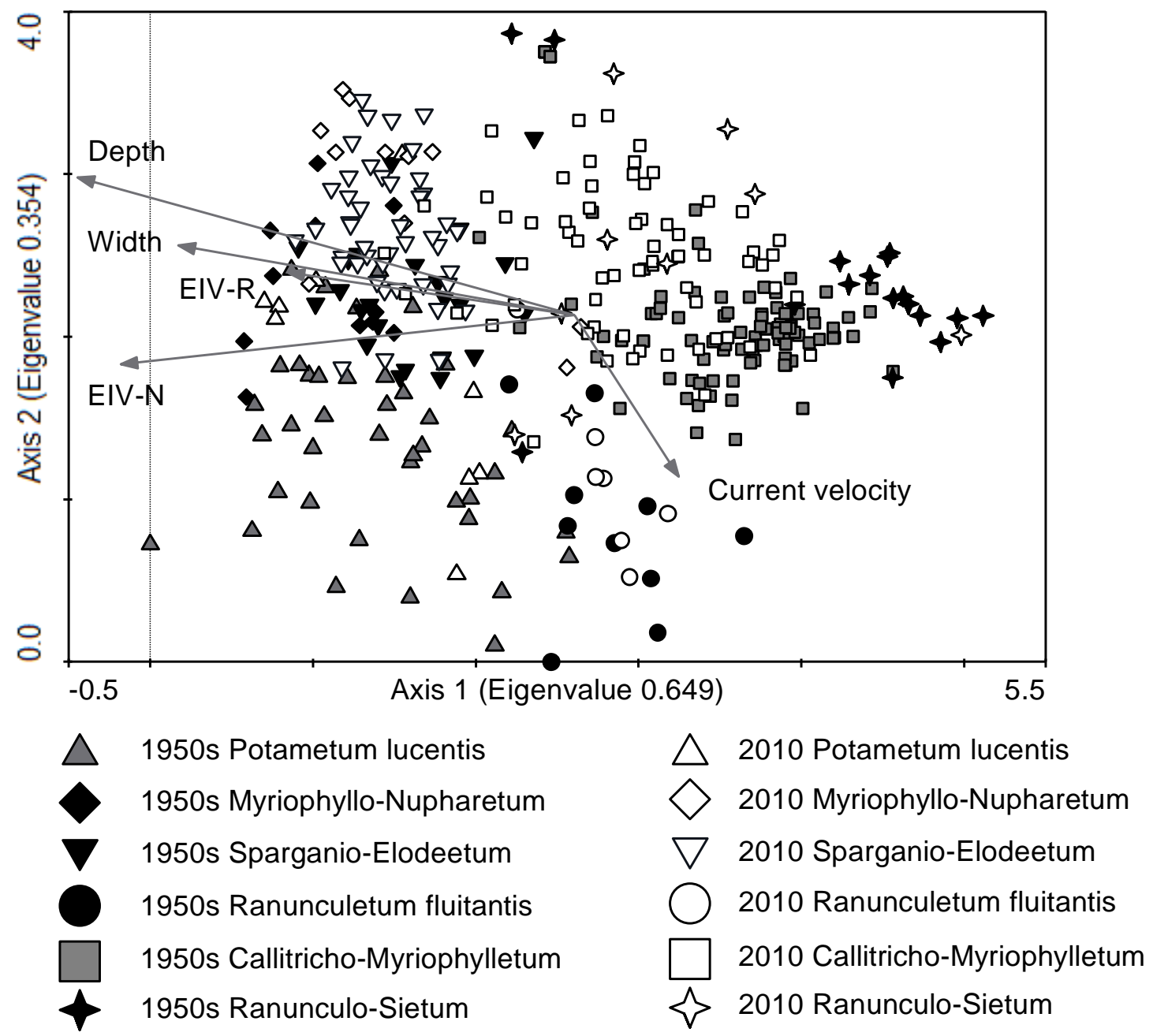

Figure 4.4 DCA graph showing all relevés that could be assigned to associations after Preising et al. (1990) (198 relevés from the 1950s and 145 relevés from 2010/2011). Environmental variables were included as additional information. See Table 4.4 for correlations of the DCA axes with environmental factors

Table 4.4 Correlation coefficients after Spearman and $p$ values of the relationships between time (sampling years) or environmental variables and DCA axes 1 and 2 for 343 relevés that were classified to the association level following Preising et al. (1990)

\begin{tabular}{lrcrc}
\hline Parameter & r DCA axis 1 & p & r DCA axis 2 & p \\
\hline Time & -0.20 & ${ }^{* * *}<0.001$ & 0.44 & ${ }^{* * *}<0.001$ \\
Current velocity & 0.53 & ${ }^{* * *}<0.001$ & -0.35 & ${ }^{* * *}<0.001$ \\
Reach width & -0.32 & ${ }^{* * *}<0.001$ & -0.01 & 0.854 \\
Reach depth & -0.49 & ${ }^{* * *}<0.001$ & 0.02 & 0.709 \\
EIV - temperature & -0.59 & ${ }^{* * *}<0.001$ & -0.09 & 0.099 \\
EIV - soil reaction & -0.22 & ${ }^{* * *}<0.001$ & 0.14 & ${ }^{*} 0.012$ \\
EIV - nutrients & -0.34 & ${ }^{* * *}<0.001$ & 0.08 & 0.138 \\
\hline
\end{tabular}




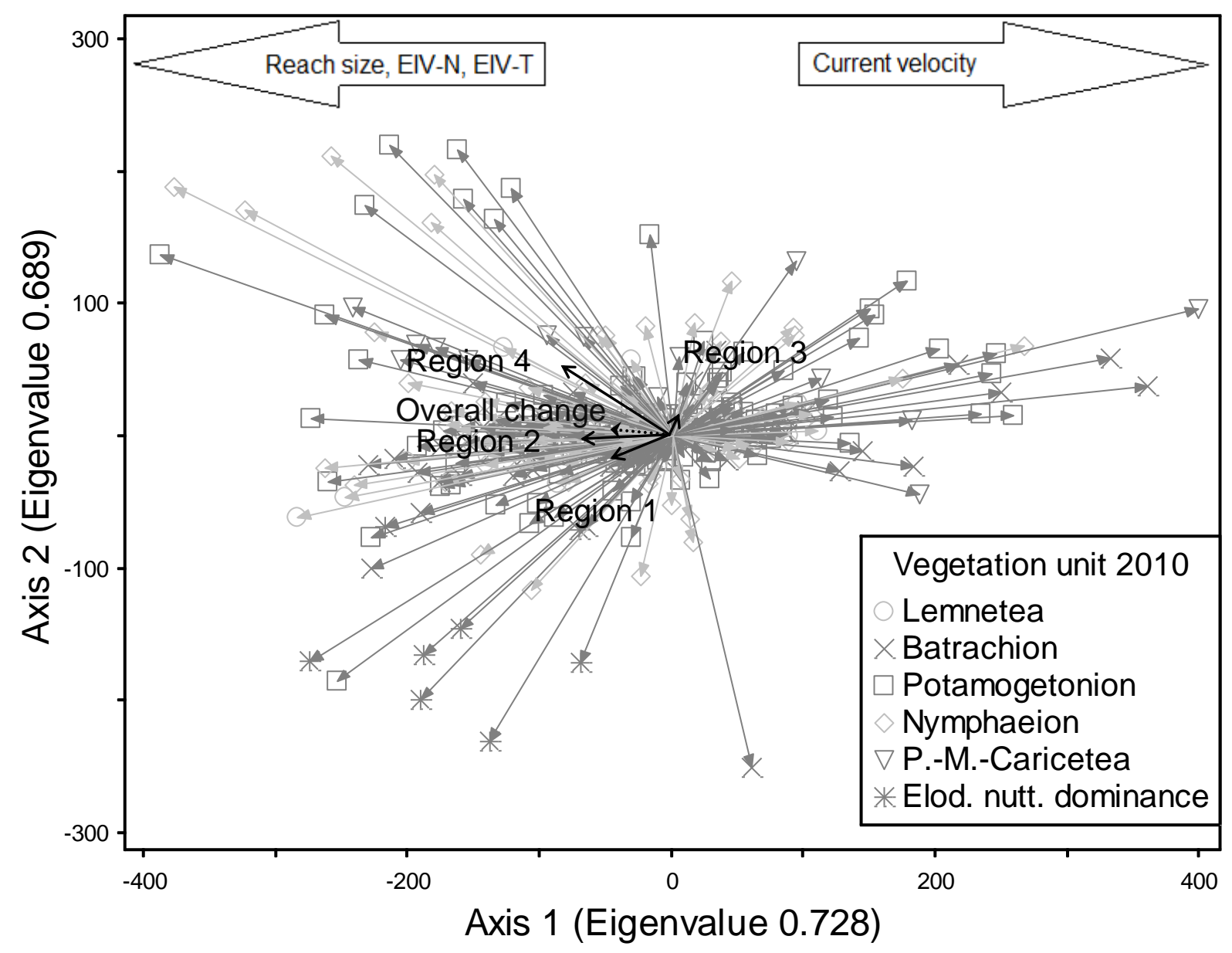

Figure 4.5 Successional vectors translated to origin (1950s) of 325 pairs of vegetation relevés (1950s - 2010/2011 contrast) assigned to a vegetation unit according to the system of Chytrý (2011) or referring to Elodea nuttallii dominance stands with the arrow pointing to the corresponding 2010/2011 relevé (grey arrows). The resulting direction of overall change is indicated with a dotted arrow, the directions of change for the relevés of each region are indicated with black arrows. Seven relevé pairs containing outliers were omitted. See Table 4.5 in the Appendix and Table 4.6 for correlations of the DCA axes and the successional vectors with environmental variables

Table 4.6 Correlation coefficients after Spearman and $p$ values of the relationships between environmental variables (changes over time per plot) and the successional vector lengths for a total of 650 relevés that were used for the trajectory analysis, differentiated after regions

\begin{tabular}{lrlrlrrrrrr}
\hline Parameter & $\begin{array}{l}\text { All } \\
\text { regions }\end{array}$ & $\mathbf{p}$ & $\begin{array}{l}\text { Regi- } \\
\text { on 1 }\end{array}$ & $\mathbf{p}$ & $\begin{array}{l}\text { Regi- } \\
\text { on 2 }\end{array}$ & $\mathbf{p}$ & $\begin{array}{l}\text { Regi- } \\
\text { on 3 }\end{array}$ & $\begin{array}{l}\text { p } \\
\text { Regi- }\end{array}$ & $\mathbf{p}$ \\
\hline $\begin{array}{l}\text { Change in } \\
\text { current velocity }\end{array}$ & -0.11 & 0.053 & 0.03 & 0.827 & 0.08 & 0.427 & -0.09 & 0.393 & 0.08 & 0.563 \\
$\begin{array}{l}\text { Change in reach } \\
\text { width }\end{array}$ & 0.04 & 0.525 & 0.19 & 0.102 & 0 & 0.954 & -0.07 & 0.528 & 0.27 & ${ }^{*} 0.043$ \\
$\begin{array}{l}\text { Change in reach } \\
\text { depth }\end{array}$ & -0.02 & 0.730 & -0.02 & 0.842 & 0 & 0.754 & -0.07 & 0.540 & 0.27 & ${ }^{*} 0.046$ \\
$\begin{array}{l}\text { Change in EIV - } \\
\text { temperature }\end{array}$ & -0.02 & 0.719 & -0.05 & 0.694 & 0.32 & ${ }^{* * *}<0.001$ & 0.05 & 0.650 & -0.26 & 0.055 \\
$\begin{array}{l}\text { Change in EIV - } \\
\text { soil reaction }\end{array}$ & -0.06 & 0.280 & -0.08 & 0.514 & 0.21 & ${ }^{*} 0.031$ & -0.11 & 0.305 & -0.26 & 0.050 \\
$\begin{array}{l}\text { Change in EIV - } \\
\text { nutrients }\end{array}$ & 0.09 & 0.126 & -0.03 & 0.788 & 0.42 & ${ }^{* * *}<0.001$ & -0.01 & 0.909 & -0.03 & 0.808 \\
\hline
\end{tabular}




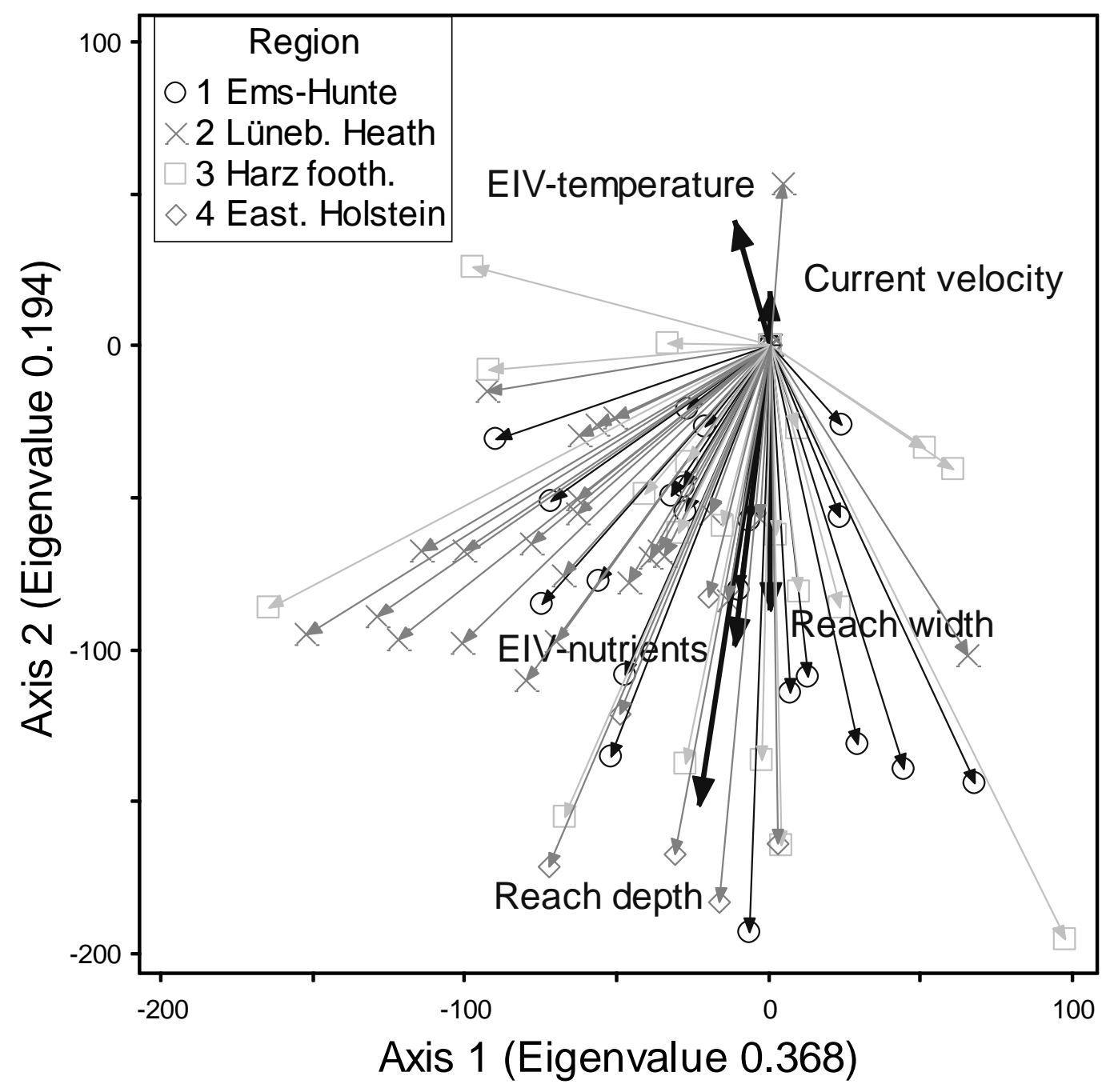

Figure 4.6 Successional vectors translated to origin (1950s) of the summarized relevés for each of the 70 streams or rivers in the four studied regions (thin arrows, 1950s - 2010/2011 contrast) together with environmental variables (thick arrows). See Table 4.7 in the Appendix and Table 4.8 for correlations of the DCA axes and successional vectors with environmental factors

Table 4.8 Correlation coefficients after Spearman and $p$ values of the relationships between environmental variables (changes over time per running water) and the successional vector lengths for 70 streams or rivers, differentiated after regions

\begin{tabular}{|c|c|c|c|c|c|c|c|c|c|c|}
\hline Parameter & $\begin{array}{l}\text { All } \\
\text { regions }\end{array}$ & $\mathbf{p}$ & $\begin{array}{l}\text { Regi- } \\
\text { on } 1\end{array}$ & $\mathbf{p}$ & $\begin{array}{l}\text { Regi- } \\
\text { on } 2 \\
\end{array}$ & $p$ & $\begin{array}{l}\text { Regi- } \\
\text { on } 3\end{array}$ & $p$ & $\begin{array}{l}\text { Regi- } \\
\text { on } 4\end{array}$ & $\mathbf{p}$ \\
\hline $\begin{array}{l}\text { Change in } \\
\text { current velocity }\end{array}$ & -0.15 & 0.350 & 0.20 & 0.470 & 0.11 & 0.680 & -0.10 & 0.873 & -0.37 & 0.468 \\
\hline $\begin{array}{l}\text { Change in reach } \\
\text { width }\end{array}$ & 0.27 & 0.103 & 0.14 & 0.642 & 0.14 & 0.628 & -0.40 & 0.600 & -0.26 & 0.623 \\
\hline $\begin{array}{l}\text { Change in reach } \\
\text { depth }\end{array}$ & -0.24 & 0.121 & -0.17 & 0.531 & -0.16 & 0.576 & -0.30 & 0.624 & -0.49 & 0.329 \\
\hline $\begin{array}{l}\text { Change in EIV - } \\
\text { temperature }\end{array}$ & 0.06 & 0.607 & -0.26 & 0.259 & 0.35 & 0.085 & 0.07 & 0.761 & 0.6 & 0.208 \\
\hline $\begin{array}{l}\text { Change in EIV - } \\
\text { soil reaction }\end{array}$ & 0.22 & 0.064 & 0.18 & 0.437 & 0.29 & 0.161 & 0.03 & 0.917 & 0.6 & 0.208 \\
\hline $\begin{array}{l}\text { Change in EIV - } \\
\text { nutrients }\end{array}$ & 0.36 & ${ }^{\star \star} 0.002$ & 0.46 & ${ }^{*} 0.035$ & 0.42 & ${ }^{*} 0.038$ & 0.34 & 0.158 & 0.43 & 0.397 \\
\hline
\end{tabular}




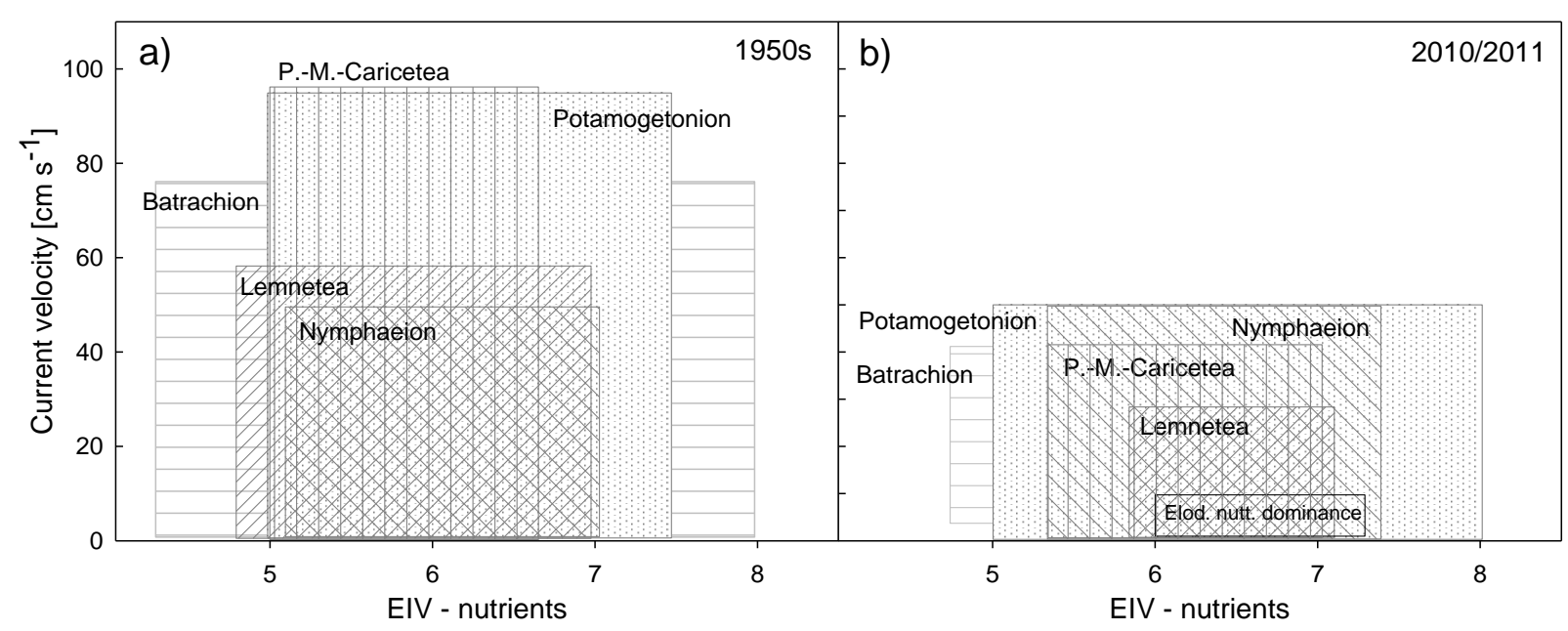

Figure 4.7 Ecograms with the two environmental axes current velocity and Ellenberg indicator value for nutrients plotted for (a) five vegetation units classified after Chytrý (2011) in the 1950s and (b) in 2010/2011 (in 2010/2011, Elodea nuttallii dominance stands were additionally plotted)

\section{Discussion}

\section{Weaknesses and strengths of the sampling and classification approaches}

The sampling and classification of river macrophyte vegetation is associated with a number of problems that relate to the biology of the macrophyte flora, the linear structure of the ecosystem with steep environmental gradients from the river bank to the stream line, and the high dynamics of the assemblages (Mitchell \& Rodgers 1986, Boschilia et al. 2008, Haury \& Muller 2008). In running waters, stochastic events are more important than in stagnant waters, many taxa are highly plastic, and species richness is typically relatively low (Gessner 1955, Haslam 1987). Most historical vegetation relevés in European inland waters were taken in the tradition of the Zürich-Montpellier school of vegetation science with small plot sizes (typically $<30 \mathrm{~m}^{2}$ ) and preferential selection of vegetation stands with presence of diagnostic species. Such an approach may overestimate mean species richness and might be biased in terms of representativeness of community composition and structure. For the sake of comparability, we took the recent relevés as close as possible to the historical sites and also selected the precise plot location preferentially in the same manner as six decades ago. The classification of the relevé material also requires taking subjective decisions in the analysis and different classification systems necessarily lead to partly deviating results.

Our study aim was not to assess the goodness of the two applied classifications, but we asked what information can be gained from these classifications about the fundamental change having taken place in macrophyte community structure and vegetation patterns in the past decades. We assumed that two independent classification systems should lead to more robust conclusions on vegetation change than one system alone. While hierarchical 
phytosociological classification concepts are somewhat artificial, such approaches have the advantage that they can also provide information on community impoverishment and community homogenization over time. The phytosociological analysis of the relevé material from the 1950s and 2010/2011 after Preising et al. (1990) showed a large decrease in the proportion of relevés that could be assigned to the association level, indicating losses in characteristic taxa. The decline in phytosociological character species gives reason to assume that many of the syntaxonomic units that were described for north-west German water courses in the past decades do not represent recognizable types of macrophyte assemblages with sufficient homogeneity and wider distribution anymore. However, the possibility of assigning relevés with different degrees of impoverishment to different levels in the syntaxonomic hierarchy may represent a strength of this approach when community change is to be examined. In the classification system of Chytrý (2011), dominance structures are decisive for classification and due to the prevalence of mono-dominant stands, the number of macrophyte associations identified in our study regions (1950s: 29, 2010/2011: 23) was much greater than with the Preising system. For the assessment of change at the community level, it can be viewed as an advantage of this system that every relevé can be assigned unambiguously to a certain association.

\section{Landscape-scale diversity of macrophyte assemblages in historical and recent time}

With a macrophyte flora (vascular plants and mosses) of roughly 80 hydro- and amphiphytic or helophytic taxa, the species pool in the streams and rivers of the north-west German lowlands is relatively small. One reason is the rather restricted habitat diversity in the water courses of this landscape that was formed by the penultimate and last Ice Ages and is harboring predominantly potamal streams and rivers with relatively low current velocity. Only very few water courses of the Central German uplands were included in the study and thus, rhithral streams are present only in the study regions 2 (Lüneburg Heath) and 3 (northern Harz foothills) with a more or less undulating relief. Characteristic for the macrophyte vegetation of the north-west German lowlands are submerged assemblages with taxa such as Myriophyllum alterniflorum or Ranunculus fluitans, which in a number of phytosociological systems (e.g. Preising et al. 1990, Rennwald 2000, Berg et al. 2004) are classified in the Callitricho-Batrachietalia order (class Potamogetonetea), that comprises the largest part of Europe's macrophyte vegetation in lotic waters. These (at least in former times) relatively species-rich assemblages are completed by communities assignable to two other Potamogetonetea orders with mostly species-poor communities, the pondweed assemblages (Potamogetonetalia with three alliances) and the water lily assemblages (Nymphaeetalia with two alliances). Less than 15 percent of the relevés were assigned to 
other vegetation classes than the Potamogetonetea (Lemnetea, Phragmitetea/PhragmitoMagno-Caricetea, Platyhypnidio-Fontinalietea antipyreticae).

Following Preising et al. (1990), the phytosociological analysis revealed the presence of 3 orders, 6 alliances and 6 associations within the Potamogetonetea, the 'core class' of macrophyte vegetation. The single most widespread alliance was the Ranunculion fluitantis with its quantitatively most important association, the Callitricho-Myriophylletum. According to their distribution and apparent site preferences, the six Potamogetonetea associations currently present in the study regions according to the Preising system can be characterized as follows:

(1) the Callitricho-Myriophylletum showed a preference for relatively fast-flowing, cool, but nutrient-poor streams and small rivers on base-poor glacial deposits (characteristic for the rhithral waters in particular of the outwash plains of the Lüneburg Heath and its surroundings);

(2) the Ranunculo-Sietum preferred relatively slow-flowing, cool, but base-rich water courses (mainly in waters originating in the loess deposits of the northern Harz foothills);

(3) the Ranunculetum fluitantis was mainly found in relatively fast-flowing, relatively warm and nutrient-enriched water courses (in regions with higher relief energy: Harz foothills, Lüneburg Heath);

(4) the Potamogetonetum lucentis inhabited slowly to faster flowing, relatively eutrophic, potamal river reaches (mainly in the Ems-Hunte and eastern Holstein regions);

(5) the Sparganio-Elodeetum colonizes relatively slow-flowing, moderately nutrientrich water courses in the base-poor glacial deposits of the Ems-Hunte moraine country; and

(6) the Myriophyllo-Nupharetum is characteristic for relatively warm, nearly stagnant, meso- to eutrophic, potamal water courses (mainly in the Ems-Hunte and Harz foothills regions). The latter assemblage was often associated with lemnid carpets, in particular in the 2010/2011 survey.

Comparing the 1950s data with the recent survey reveals not only a markedly reduced mean species richness of the assemblages (from 4.7 to 3.8 species per relevé, Steffen et al. 2013), but also profound change in the relative abundance of the assemblages in the four study regions. In addition, a general reduction in community diversity at the landscape scale was recognized. Four of the six Potamogetonetea associations assigned after Preising et al. (1990) suffered severe frequency losses (by 30 to $78 \%$ ) in the each 330 relevés between the 1950s and 2010/2011 with large reductions also observed in the once most widespread associations Callitricho-Myriophylletum and Potamogetonetum lucentis. Two types of assemblages, which were in the 1950s assigned to the Potamogetonion graminei and the Hydrocharition, were no longer present in 2010/2011. On the other hand, assemblages assignable to the alliance Nymphaeion albae (and order Nymphaeetalia, 
$+47 \%$ ), i.e. communities dominated by floating-leaved, rooted macrophytes, and lemnid carpets (class Lemnetea) that often occurred together with Sagittaria sagittifolia, are much more widespread in recent time than 60 years ago. A large spread was observed in particular for the Nymphaeion association Sparganio-Elodeetum, which roughly doubled the number of its occurrences. This impressive shift from Potamogetonetalia (and Batrachietalia) communities to Nymphaeetalia communities was overlain by a general impoverishment of the assemblages at the plot level, many of which lost their indicative species. Today, only two associations of the phytosociological system of Preising et al. (1990) (CallitrichoMyriophylletum and Sparganio-Elodeetum) can be considered as being more widespread.

When applying the alternative classification system after Chytrý (2011), which puts more weight on dominance relations than on the presence/absence of diagnostic species, the relevés were assigned to 3 Potamogetonetea alliances with 30 associations. According to this classification, the Potamogetonion was the most common alliance, but on the association level, the Nymphaeo albae-Nupharetum luteae (alliance Nymphaeion) and the Callitricho hamulatae-Ranunculetum fluitantis (Batrachion) prevailed. Both classification approaches revealed that Nymphaeetalia/Nymphaeion stands have gained importance during the last 60 years at the expense of Batrachietalia/Batrachion and Potamogetonetalia/Potamogetonion assemblages.

With the reduction in plot-level species richness, the macrophyte assemblages have become more similar to each other resulting in the increase of the average $B_{S C}$ index. The homogenization of river macrophyte vegetation from the 1950 s to $2010 / 2011$ is also demonstrated by Figure 4.6 showing a reduction in niche space (current velocity vs. nutrient availability) occupied by the assemblages in recent time. One consequence is the apparent larger overlap of the niches of the different vegetation units in 2010/2011, which relates to the species loss. Most of the species that were lost from the regional species pool of northwest German running waters over the past 60 years are taxa with relatively narrow ecological niches that often served as character species for the syntaxonomic units at lower levels. The large frequency increase in assemblages assignable only to the alliance or order levels after Preising et al. (1990) (by 15 and $62 \%$, respectively) evidences that many macrophyte stands must be considered as impoverished 'residual communities' (Fragmentgesellschaften) in the sense of Brun-Hool (1966) in our times. The fate of the north-west German river macrophyte vegetation since the 1950s is paralleled by the development in terrestrial vegetation types of the cultural landscape of Central Europe, notably the arable field vegetation (Meyer et al. 2010) and the vegetation of managed grasslands (Wesche et al. 2012). 


\section{Drivers of community change}

The likely main causes of macrophyte community impoverishment and vegetation homogenization at the landscape level are river construction works and eutrophication (Phillips et al. 1978, Pedersen et al. 2006). In north-west Germany, many water courses were straightened and deepened in the course of agricultural intensification to increase runoff, mostly in the 1950s to 1970s. This resulted in the loss of natural floodplain areas with the typical mosaic of side arms, smaller and larger, partly stagnant water bodies, and swamps adjacent to the main rivers. Drag-sensitive species such as Nymphaea alba and Ranunculus circinatus lost their sheltered habitats and are no longer elements of the macrophyte vegetation of these running waters in recent time. Although our data indicate that many of the investigated water courses were broadened and deepened in the course of engineering works in the last decades especially in the regions 1 (Ems-Hunte) and 4 (eastern Holstein), current velocity seems to be lower in general than in historical time. In principal, a "rhithralization" (more rapid discharge, change to rhithral biotic communities) can be expected as a consequence of river engineering measures (Moog 2002). In our regions, in contrast, a "potamalization" (reduction of the current velocity, change to potamal biota) has taken place after water course regulation, which likely results from the construction of barrages and weirs in many water courses that increased the water level and reduced flow. The correlation of the plot-wise successional vectors for region 4 with increased reach widths and depths indicates a direct relation of the vegetation change in eastern Holstein with river engineering works.

The maintenance of water courses is a legal duty in the study region since 1957 resulting in regular dredging and mowing of most streams and rivers and their banks, thereby eliminating many disturbance-sensitive species. Species with deeper anchoring in the sediment such as Sagittaria sagittifolia or Sparganium emersum may then profit from reduced competition. Maintenance works also increase the load of suspended particles reducing light transmissivity in the water body (Altmüller \& Dettmer 1996). This effect adds to the eutrophication-caused increase in phytoplankton density, which also increases turbidity favoring surface-floating species such as lemnids and nymphaeids over submerged growth forms (Hough et al. 1989). Increasing importance of surface-floating species but declines of rooted, submerged macrophytes has also been observed over the past decades in Dutch streams and was related to eutrophication and increased water turbidity (Mesters 1995). In north-west Germany, agricultural intensification with high inputs of $N$ and $P$ into the water courses proceeded more rapidly in the regions 1, 3 and 4 than in region 2 (Lüneburg Heath) and took place mainly in the 1960s to 1980s (Behrendt et al. 1999). The Lüneburg Heath with its extended forests and, at least in some parts, less-intense agriculture has preserved richer macrophyte vegetation in the streams and rivers; this was already recognized by Herr 
et al. (1990). Nevertheless, the correlation of the successional vectors with increased mean EIVs for temperature, soil reaction and nutrients in the study region 2 hints at a strong influence of physico-chemical factors on macrophyte vegetation change in the water courses of the Lüneburg Heath region, where the running waters have less been impacted by construction works since the 1950s. While the amount of $P$ fertilizer used on Germany's farmland peaked in the 1970s and declined recently to the level of the 1950s, $N$ fertilizer input remained four times higher than 60 years ago (Statistisches Bundesamt 2012). Besides the suppression of light-demanding submersed plants, eutrophication is likely the main driver behind the frequency increase in the eutraphent assemblage Sparganio-Elodeetum since the 1950s. Moreover, the mean EIV for nutrients has significantly increased in this assemblage and in the Myriophyllo-Nupharetum (and seems to have increased in three other associations as well) indicating within-community shifts in species composition towards more nutrientdemanding taxa such as the eutraphent neophyte Elodea nuttallii and increased abundances of Myriophyllum spicatum, Lemna minor and Spirodela polyrhiza.

The characteristic species of the Potamogetonetum lucentis in the system of Preising et al. (1990), Potamogeton lucens and P. perfoliatus, are known to occur in meso- and also eutrophic waters, but are not very tolerant to pollution or highly eutrophic to hypertrophic conditions (Casper \& Krausch 1980, Berg et al. 2004). A decline of species of the genus Potamogeton in running waters over several decades has been reported by various earlier studies and was attributed to changes in physical and chemical habitat conditions (Grube 1975, Wiegleb et al. 1991, Riis \& Sand-Jensen 2001). Due to their potamid growth form with predominant formation of submerged leaves, many Potamogeton species are largely dependent on effective light transmission through the water column and thus are sensitive to turbidity and high loads of suspended particles (Heegaard et al. 2001, Garniel 2008). In contrast, the Nymphaeion albae character species Nuphar lutea is relatively tolerant towards turbidity and also drag due to its ability to form both submerged and floating leaves (Berg et al. 2004, Bal et al. 2011). 


\section{Conclusions}

The macrophyte vegetation of north-west German running waters has undergone profound change in the last sixty years, which affected the species composition, plot-level diversity, the regional species pools, and the relative abundance of community types at the landscape level. Despite important regional differences in the development, a similar principal trend was detected in all four study regions suggesting that our results may be valid for the larger part of northern Central Europe. Species lost were mainly specialist taxa with high affinity to certain macrophyte assemblages. This highlights the value of indicator species-based classification systems with small plot sizes for detecting community- and landscape-level vegetation change in running waters. Despite considerable conceptual differences between the two used classification approaches, both analyses revealed a major vegetation shift from prevailing submerged rooted to floating-leaved rooted and lemnid macrophytes. The hierarchical phytosociological system bears the potential of estimating the degree of anthropogenic community impoverishment. Four of the six Potamogetonetea associations after Preising et al. (1990) have markedly decreased since the 1950s, other assemblages have disappeared completely, which urgently demands for more effective conservation and restoration measures in running waters.

\section{Acknowledgments}

For making access to historical vegetation relevés possible we thank Richard Pott (Hannover), the host of the Tüxen archive. Having helped with species identifications, we thank Günther Dersch (Göttingen) for the determination of Callitriche samples, Gerhard Wiegleb (Cottbus) for the identification of Potamogeton and Ranunculus specimen and Sebastian Dittrich (Göttingen) for the identification of bryophyte specimen. We are also thankful to Thomas Becker (Trier) for his advice on the data handling and to Uta Müller (Berlin) for her help with the field work. 


\section{References}

Altmüller, R. \& R. Dettmer (1996): Unnatürliche Sandfracht in Geestbächen - Ursachen, Probleme und Ansätze für Lösungsmöglichkeiten - am Beispiel der Lutter. Informationsdienst Naturschutz Niedersachsen 16(5): 222-237.

Bal, K.D, T.J. Bouma, K. Buis, E. Struyf, S. Jonas, H. Backx \& P. Meire (2011): Trade-off between drag reduction and light interception of macrophytes: comparing five aquatic plants with contrasting morphology. Functional Ecology 25: 1197-1205.

Behrendt, H., P. Huber, M. Ley, D. Opitz, O. Schmoll, G. Scholz, \& R. Uebe (1999): Nährstoffbilanzierung der Flussgebiete Deutschlands. UBA-Texte 75: $288 \mathrm{p}$.

Berg, C., J. Dengler, A. Abdank \& M. Isermann (2004): Die Pflanzengesellschaften Mecklenburg-Vorpommerns und ihre Gefährdung. Textband. Weißdorn-Verlag, Jena: $606 \mathrm{p}$.

Best, E.P.H. (1988): The phytosociological approach to the description and classification of aquatic macrophytic vegetation. In: Symoens, J.J. (ed.): Vegetation of inland waters handbook of vegetation science 15/1: 155-182.

Boschilia, S.M., E.F. Oliveira \& S.M. Thomaz (2008): Do aquatic macrophytes co-occur randomly? An analysis of null models in a tropical floodplain. Oecologia 156(1): 203214.

Bouxin, G. (2011): Évolution de la végétation macrophytique et trophie dans deux ruisseaux du bassin hydrographique de la molignée (condroz, belgique). Journal of Water Science 24: 253-266.

Braun-Blanquet, J. (1964): Pflanzensoziologie, Grundzüge der Vegetationskunde. Springer, Wien.

Brun-Hool, J. (1966): Ackerunkraut-Fragmentgesellschaften. In: Tüxen, R. (ed.): Anthropogene Vegetation - Bericht über das internationale Symposium in Stolzenau 1961 der Internationalen Vereinigung für Vegetationskunde: 38-50.

Buttler, K.P. \& M. Thieme (2011): Florenliste von Deutschland - Gefäßpflanzen, Version 3. Frankfurt a.M., http://www.kp-buttler.de [14.01.2013]

Casper, S.J. \& H.D. Krausch (1980): Pteridophyta und Anthophyta Part 1: Lycopodiaceae bis Orchidaceae. In: H. Ettl, J. Gerloff, H. Heynig (edts), Süsswasserflora von Mitteleuropa 23. Fischer, Stuttgart: $403 \mathrm{p}$.

Chytrý, M. (2011): Vegetace České republiky 3. Vodní a mokřadní vegetace [Vegetation of the Czech Republic 3. Aquatic and wetland vegetation]. Academia, Prague: $827 \mathrm{p}$.

Dawson, F.G., P.J. Raven \& M.J. Gravelle (1999): Distribution of the morphological groups of aquatic plants for rivers in the U.K. Hydobiologia 415: 123-130.

Deutscher Wetterdienst (2013):

http://www.dwd.de/bvbw/appmanager/bvbw/dwdwwwDesktop?_nfpb=true\&_pageLab el=_dwdwww_klima_umwelt_klimadaten_deutschland\&T82002gsbDocumentPath=N avigation\%2FOeffentlichkeit\%2FKlima_Umwelt\%2FKlimadaten\%2Fkldaten_kosten frei\%2Fausgabe_monatswerte_node.html\%3F_nnn\%3Dtrue [15.01.2013]

Ellenberg, H., H.E. Weber, R. Düll, V. Wirth, W. Werner \& D. Paulissen (2001): Zeigerwerte von Pflanzen in Mitteleuropa. Scripta Geobotanica 18: 3-262.

Ellenberg, H. \& C. Leuschner (2010): Vegetation Mitteleuropas mit den Alpen. 6th ed. Ulmer, Stuttgart: $1334 \mathrm{p}$.

Fischer, E. (1995): Die Vegetation der Hase und ihres Auegebietes von der Quelle bis Bramsche. Osnabrücker Naturwissenschaftliche Mitteilungen 20/21: 343-374. 
Garniel, A. (2008): Wasserpflanzen der Fließgewässer und Gräben, Informationen zum Verständnis ihrer Lebensstrategien als Grundlage für Erhaltungs- und Fördermaßnahmen in Schleswig-Holstein und Hamburg. Berichte des Botanischen Vereins zu Hamburg 24: 1-221.

Gelbrecht, J., E. Driescher, H. Lademann, J. Schonfelder \& H.J. Exner (1996): Diffuse nutrient impact on surface water bodies and its abatement by restoration measures in a small catchment area in north-east Germany. Water Science and Technology 33: 167-174.

Gessner, F. (1955): Hydrobotanik - die physiologischen Grundlagen der Pflanzenverbreitung im Wasser - 1. Energiehaushalt. VEB Verlag der deutschen Wissenschaften, Berlin: $517 \mathrm{p}$.

Grube, H.-J. (1975): Die Makrophytenvegetation der Fließgewässer in Süd-Niedersachsen und ihre Beziehungen zur Gewässerverschmutzung. Diss., Göttingen: 456 p.

Haslam, S.M. (1987). River plants of western Europe: the macrophytic vegetation of watercourses of the European Economic Community. Cambridge University Press, Cambridge: $512 \mathrm{p}$.

Haury, J. S. \& Muller (2008): Les communautés de macrophytes: typologie, dynamique et production. Ingénieries EAT numéro spécial - plantes aquatiques d'eau douce: biologie, écologie et gestion: 37-50.

Heegaard, E., H.H. Birks, C.E. Gibson, S.J. Smith \& S. Wolfe-Murphy (2001): Speciesenvironmental relationships of aquatic macrophytes in Northern Ireland. Aquatic Botany 70: 175-223.

Herr, W., G. Wiegleb \& D. Todeskino (1989a): Veränderungen von Flora und Vegetation ausgewählter Fließgewässer Niedersachsens nach vierzig Jahren (1946/1986). Naturschutz und Landschaftspflege in Niedersachsachsen 18: 121-144.

Herr, W., D. Todeskino \& G. Wiegleb (1989b): Übersicht über Flora und Vegetation der niedersächsischen Fließgewässer unter besonderer Berücksichtigung von Naturschutz und Landschaftspflege. Naturschutz und Landschaftspflege in Niedersachsen 18: 145-283.

Herr, W., D. Todeskino \& G. Wiegleb (1990): Survey of macrophytic vegetation in North German water courses. Tasks for Vegetation Science 25: 109-116.

Hill, M.O. \& H.G. Gauch (1980): Detrended correspondence analysis: An improved ordination technique. Vegetatio 42: 47-58.

Holmes, N.T.H. \& B.A. Whitton (1977): The macrophytic vegetation of the river Tees in 1975: Observed and predicted changes. Freshwater Biology 7: 43-60.

Hoppe, A. (2005): Das Reinhold-Tüxen-Archiv am Institut für Geobotanik der Universität Hannover. Tuexenia 25: 463-474.

Hough, R.A., M.D. Fornwall, B.J. Negele, R.L. Thompson \& D.A. Putt (1989): Plant community dynamics in a chain of lakes: principal factors in the decline of rooted macrophytes with eutrophication. Hydrobiologia 173: 199-217.

Kohler, A. (1978): Methoden der Kartierung von Flora und Vegetation von Süßwasserbiotopen. Landschaft und Stadt 10: 23-85.

Koperski, M., M. Sauer, W. Braun \& S.R. Gradstein (2000): Referenzliste der Moose Deutschlands. Schriftenreihe für Vegetationskunde 34: $519 \mathrm{p}$.

Malmqvist, B. \& S. Rundle (2002): Threats to the running water ecosystems of the world. Environmental Conservation 29: 134-153.

McCune, B., J.B. Grace \& D.L. Urban (2002): Analysis of ecological communities. MjM Software Design, Gleneden Beach: 300 p. 
Mitchell, D.S. \& K.H. Rodgers (1986): Seasonality / aseasonality of aquatic macrophytes in Southern Hemisphere inland waters. Hydrobiologia 125: 137-150.

Meyer, S., B. Krause, K. Wesche, \& C. Leuschner (2010): Changes in Central German arable plant communities over the last 50 years: a semi-quantitative study. Proceedings of 15th EWRS symposium (Kapsvoár, Hungary): 135-136.

Mesters, C. (1995): Shifts in macrophyte species composition as a result of eutrophication and pollution in Dutch transboundary streams over the past decades. Journal of Aquatic Ecosystem Health 4: 295-305.

Moog, O. (2002): Fauna aquatica austriaca - edition 2002. Wasserwirtschaftskataster, Bundesministerium für Land- und Forstwirtschaft, Vienna: $92 \mathrm{p}$.

Paal, J., T. Trei \& M. Viik (2007): Vegetation of Estonian water courses III; drainage basins of the Moonsund Sea, the Gulf of Riga and Saaremaa Island. Annales Botanici Fennici 44: 321-344.

Passarge, H. (1982): Hydrophyten-Vegetationsaufnahmen. Tuexenia 2: 13-21.

Pearsall, W.H. (1918): On the classification of aquatic plant communities. Journal of Ecology 6: $75-84$.

Pedersen, T.C.M., A. Baattrup-Pedersen \& T.V. Madsen (2006): Effects of stream restoration and management on plant communities in lowland streams. Freshwater Biology 51: 161-179.

Phillips, G.L., D. Eminson \& B. Moss (1978): A mechanism to account for macrophyte decline in progressively eutrophicated freshwaters. Aquatic Botany 4: 103-126.

Pott, R. (1995): Die Pflanzengesellschaften Deutschlands. Ulmer, Stuttgart: 622 p.

Preising, E., H.-C. Vahle, D. Brandes, H. Hofmeister, J. Tüxen \& H.E. Weber (1990): Die Pflanzengesellschaften Niedersachsens - Bestandsentwicklung, Gefährdung und Schutzprobleme: Wasser- und Sumpfpflanzengesellschaften des Süßwassers. Naturschutz und Landschaftspflege in Niedersachsen 20/8: 47-161.

Preston, C.D. (1995): Pondweeds of Great Britain and Ireland. Botanical Society of the British Isles Handbook 8: 1-350.

Rennwald, E. (2000): Verzeichnis und Rote Liste der Pflanzengesellschaften Deutschlands. Schriftenreihe für Vegetationskunde 35: 1-800.

Riis, T., K. Sand-Jensen \& O. Vestergaard (2000): Plant communities in lowland Danish streams: species composition and environmental factors. Aquatic Botany 66: 255272.

Riis, T. \& K. Sand-Jensen (2001): Historical changes in species composition and richness accompanying perturbation and eutrophication of Danish lowland streams over 100 years. Freshwater Biology 46: 269-280.

Roll, H. (1939): Die Pflanzengesellschaften ostholsteinischer Fließgewässer - Limnologischsoziologische Studien. Archiv für Hydrobiologie 34: 159-305.

Schubert, R. (2008): Die Moosgesellschaften des Nationalparks Harz. Mitteilungen zur floristischen Kartierung Sachsen-Anhalt, Sonderheft 5: $81 \mathrm{p}$.

Schütz, W., U. Veit \& A. Kohler (2008): The aquatic vegetation of the Upper Danube river past and present. Large Rivers 162: 167-191.

Sculthorpe, C.D. (1967): The biology of aquatic vascular plants. Edward Arnold Publishers, London: $610 \mathrm{p}$.

Statistisches Bundesamt (2012): Produzierendes Gewerbe, Düngemittelversorgung, Wirtschaftsjahr 2011/2012. Fachserie 4, Reihe 8.2. Wiesbaden: 36 p. 
Steffen, K., T. Becker, W. Herr \& C. Leuschner (2013): Diversity loss in the macrophyte vegetation of northwest German streams and rivers between the 1950s and 2010. Hydrobiologia 713: 1-17.

van de Weyer, K. (2001): Klassifikation der aquatischen Makrophyten der Fließgewässer von Nordrhein-Westfalen gemäß den Vorgaben der EU-Wasser-Rehmen-Richtlinie. Landesumweltamt Nordrhein-Westfalen, Merkblätter 30: $108 \mathrm{p}$.

Weber, H.E. (1976): Die Vegetation der Hase von der Quelle bis Quakenbrück. Osnabrücker Naturwissenschaftliche Mitteilungen 4: 131-190.

Weber-Oldecop, D.W. (1969): Wasserpflanzengesellschaften im östlichen Niedersachsen. Diss., Hannover: $172 \mathrm{p}$.

Weber-Oldecop, D.W. (1970): Wasserpflanzengesellschaften im östlichen Niedersachsen (I.). Internationale Revue der gesamten Hydrobiologie und Hydrographie 55: 913967.

Wesche, K., B. Krause, H. Culmsee \& C. Leuschner (2012): Fifty years of change in Central European grassland vegetation: large losses in species richness and animalpollinated plants. Biological Conservation 150: 76-85.

Whitton, B.A., P.N.G. Boulton, E.M. Clegg, J.J. Gemmell, G.G. Graham, R. Gustar \& T.P. Moorhouse (1998): Long-term changes in macrophytes of British rivers: A. River Wear. The Science of the Total Environment 210/211: 411-426.

Wiegleb, G. (1981): Probleme der syntaxonomischen Gliederung der Potametea. In: Dierschke, H. (ed.): Syntaxonomie. Cramer, Vaduz: 207-249.

Wiegleb, G., H. Brux \& W. Herr (1991): Human impact on the ecological performance of Potamogeton species in northwestern Germany. Vegetatio 97: 161-172. 
Chapter 5

\section{Synthesis}
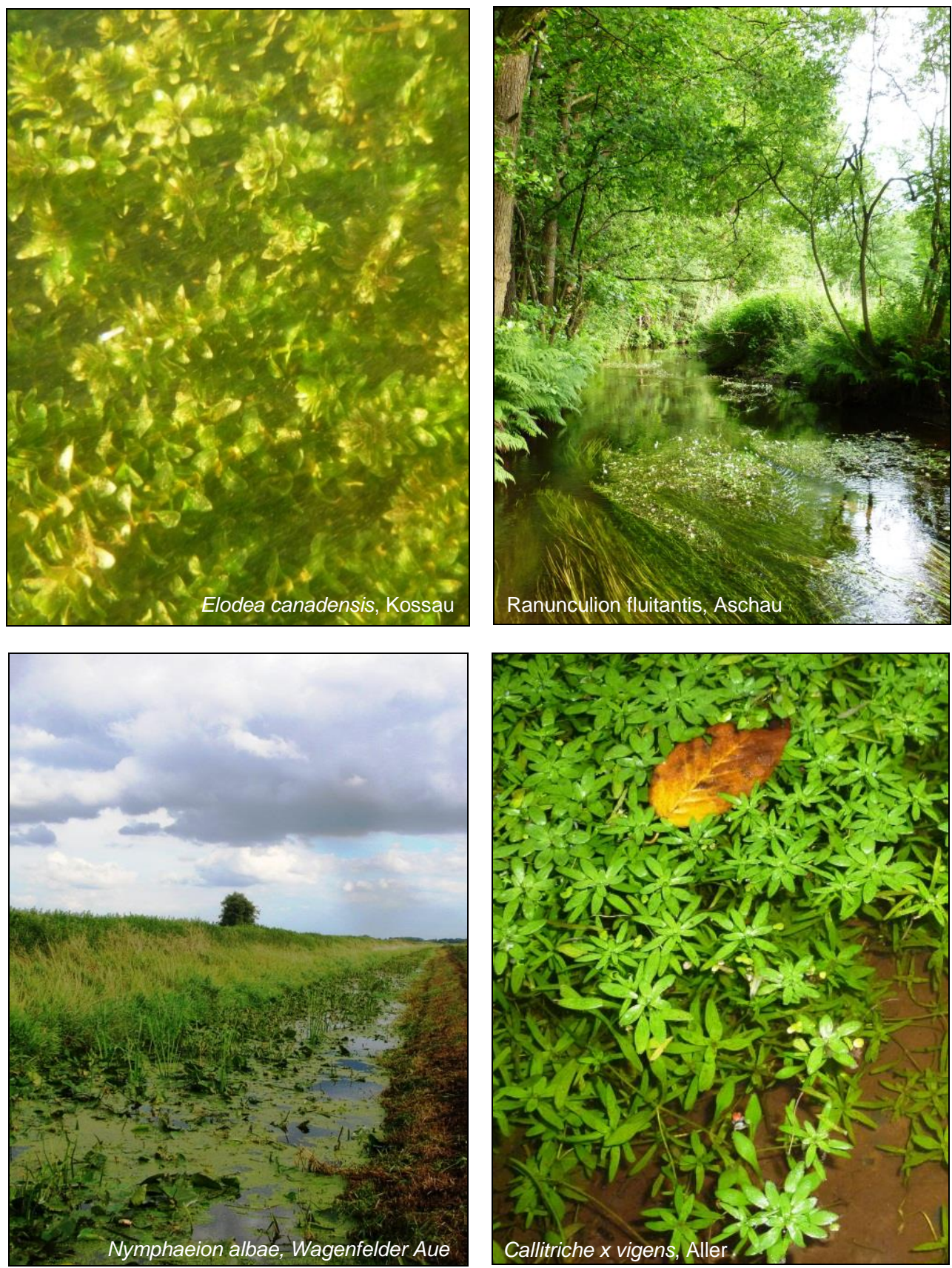


\section{Methodological remarks: assessing long-term vegetation change in}

\section{running waters with regard to bioindication}

Since the investigation of vegetation change in running waters bases on historical vegetation records with sufficient precision (species lists, cover values), the water courses coming into question for investigation are determined by the historical data available. From the experience of this study, the semi-permanent plot approach bears the potential to take account of the following aspects of aquatic vegetation, which can be considered as very useful to assess long-term changes in running waters:

\section{The species composition}

Due to the differing ecological preferences of different macrophyte species, their presence may be of indicative value. In this regard, the occurrences of stenoecious species as for example Myriophyllum alterniflorum preferring mesotrophic, rhithral waters are more meaningful than that of eurioecious ones as for example Sparganium emersum occurring under wide amplitudes of currents and trophic conditions. In this study, for example species with broad ecological tolerances and species preferring eutrophic habitats showed an increase over six decades, while mesotrophic species decreased and oligotrophic species died out. This development in the species composition hints at the anthropogenically induced eutrophication of the investigated running waters.

\section{The species richness and diversity}

The size of the species pool reflects the degree of habitat heterogeneity: the more heterogeneous the occurring habitats are, the more species can be present. The diversity and number of species per plot is to be seen in relation to stress and disturbance. In stressful environments or highly disturbed habitats, only a low number of species is able to persist within a defined area. In our example, the species pool as well as plot-level species richness and diversity decreased over the investigated time span. The losses are attributed to habitat uniformization, increased mechanical stress (loss of low-flow and stagnant water habitats that were part of the historical running waters) and regular disturbance (e.g. maintenance works) that occurred in north-west German streams and rivers in the last decades.

\section{The shares of life form (rooted vs. free-floating) and growth form (totally submerged vs. floating-leaved) types}

Rhizophytic, submerged growth forms (e.g. potamid species) depend on relatively clear water with sufficient light transmission through the water column and such are typical for oligo- to moderately eutrophic water bodies. In contrast, pleustophytic growth forms (e.g. lemnid) are also able to colonize highly eu- to hypertrophic, turbid waters. In the water courses we looked at, a shift from the predominance of potamid to the predominance of lemnid species was observed, hinting at an increase in the productivity (eutrophication). 


\section{The mean specific leaf area (SLA)}

The mean SLA (i.e. leaf surface area per $1 \mathrm{~g}$ leaf) of the macrophyte species characterizes their mechanical resistance: less resistant plants have a higher SLA (due to leaves being thin or rich in aerenchymatic tissue). In this study, the mean SLA per plot decreased over 60 years (only hydrophytes were considered), indicating an increase of robust plant species and thus increased mechanical disturbance, which can be related to the loss of sheltered habitats at the edges of the main river channels.

\section{The proportions of syntaxonomic vegetation units as related to different hierarchical levels (class, order, alliance, association)}

To assess the long-term development of the vegetation community structure, it is necessary to classify the documented species assemblages. To detect differences between historical and recent macrophyte assemblages, the syntaxonomic character and/or dominant speciesbased classifications proved to be appropriate, because they provide the opportunity to quantify the changes at the community level. After the system of Preising et al. (1990), in the vegetation stands that we looked at, the number of phytosociologically well characterized communities (associations) declined over six decades $(-26.8 \%)$, while the proportion of assemblages poorly defined by character species (orders, alliances) strongly increased (+14.8-61.7\%). Following Chytrý's (2011) system, with the possibility to assign every stand to an association, the number of recognized associations declined from 29 (1950s) to 23 (2010/2011). The apparent diversity decline at the community level is a sign for habitat homogenization in the investigated running waters.

Vegetation and environmental change in streams and rivers in northwest Germany since the 1950s

The hydrophytic flora of north-west German streams and rivers became impoverished between the 1950s and 2010. The magnitude of change with a reduction of the species pool by $27.5 \%$, accompanied by a degradation on the syntaxonomic level and a profound shift from the predominance of submerged rhizophytic (mainly potamid) species in the relevés to the predominance of pleustophytic (mainly lemnid) species, is alarming. Looking at the species with considerable changes in their frequencies of occurrence in the study sites over the last six decades, it is evident that oligo- and mesotrophic species such as the character species of the Potamogetonion graminei (e.g. Potamogeton alpinus) and of the CallitrichoMyriophylletum (e.g. Myriophyllum alterniflorum) have declined or died out, while eutrophic and generalist species such as the character species within the Lemnion gibbae (Lemna gibba, Spirodela polyrhiza) have increased (Table 5.1). This development corresponds to the increase in the mean EIV for nutrients. 
Table 5.1 Changes in the frequency of occurrence between the 1950s and 2010/2011, habitat preferences and syntaxonomic ascription after Preising et al. (1990) of 40 macrophyte species in 338 semi-permanent plots in running waters with a minimum of 3 occurrences in one of the two investigated time periods. (oligo = oligotraphent, meso = mesotraphent, eu = eutraphent, in = indifferent with regard to the nutrient content of the water; $(c)=$ character species for the vegetation unit indicated, $(d)=$ differential species)

\begin{tabular}{|c|c|c|c|c|c|}
\hline \multirow[t]{2}{*}{ Hydrophytic taxon } & \multicolumn{2}{|c|}{ Occurrences } & \multirow{2}{*}{$\begin{array}{c}\text { Change } \\
\text { [\%] }\end{array}$} & \multirow{2}{*}{$\begin{array}{l}\text { Ecological } \\
\text { preference }\end{array}$} & \multirow{2}{*}{$\begin{array}{l}\text { Syntaxonomic } \\
\text { vegetation unit }\end{array}$} \\
\hline & 1950s & $\begin{array}{l}2010 / \\
2011\end{array}$ & & & \\
\hline Myriophyllum spicatum & 3 & 19 & $+>100.0$ & $\mathrm{eu}^{1, /} / \mathrm{in}^{3}$ & Potamogetonion lucentis (c) \\
\hline Utricularia vulgaris & 2 & 10 & $+>100.0$ & meso-eu 3,4 & Nymphaeetalia (c) \\
\hline Spirodela polyrhiza & 36 & 110 & $+>100.0$ & $\mathrm{eu}^{1} / \mathrm{in}^{5}$ & Spirodeletum polyrhizae (c) \\
\hline Elodea nuttallii & 0 & 67 & +100.0 & $\mathrm{eu}^{1,2}$ & Potamogetonion pusilli (c) \\
\hline Lemna minor & 115 & 207 & +80.0 & $\operatorname{in}^{2,5}$ & LEMNETEA (c) \\
\hline Ranunculus trichophyllus & 4 & 7 & +75.0 & meso-eu ${ }^{3} /$ in $^{5,7}$ & Ranunculo-Sietum (c) \\
\hline Potamogeton nodosus & 2 & 3 & +50.0 & in $^{6}$ & Ranunculion fluitantis (c) \\
\hline Lemna gibba & 24 & 33 & +37.5 & $\mathrm{eu}^{2,5}$ & Lemnetum gibbae (c) \\
\hline Ceratophyllum demersum & 20 & 24 & +20.0 & $\mathrm{eu}^{5} /$ in $^{7}$ & POTAMETEA (c) \\
\hline Hydrocharis morsus-ranae & 8 & 9 & +12.5 & meso-eu ${ }^{2,5}$ & Hydrocharition (c) \\
\hline Sparganium emersum & 176 & 176 & \pm 0.0 & in $^{4,5}$ & $\begin{array}{l}\text { Sparganio-Elodeetum (c), } \\
\text { Ranunculion fluitantis (d) }\end{array}$ \\
\hline Sagittaria sagittifolia & 92 & 85 & -7.6 & $\mathrm{eu}^{\mathrm{b}}$ & Sparganio-Elodeetum (c) \\
\hline Callitriche palustris agg. & 144 & 122 & -15.3 & meso-eu ${ }^{3} /$ in $^{4}$ & $\begin{array}{l}\text { Sparganio-Elodeetum (c), } \\
\text { Callitricho-Batrachietalia (c) }\end{array}$ \\
\hline Nuphar lutea & 117 & 81 & -30.8 & in $^{5}$ & Myriophyllo-Nupharetum (c) \\
\hline Potamogeton pectinatus & 54 & 35 & -35.2 & $\mathrm{eu}^{5} /$ in $^{6, /}$ & $\begin{array}{l}\text { Potamogetonetalia (c), } \\
\text { Nymphaeion albae (d) }\end{array}$ \\
\hline Lemna trisulca & 51 & 32 & -37.3 & meso-eu $^{2}$ & Lemnetum trisulcae $(\mathrm{c})$ \\
\hline Callitriche hamulata & 78 & 41 & -47.4 & meso $^{1,2}$ & Callitricho-Myriophylletum (c) \\
\hline Potamogeton pusillus & 23 & 12 & -47.8 & meso-eu ${ }^{2,5}$ & Potamogetonion pusilli (c) \\
\hline Elodea canadensis & 135 & 69 & -48.9 & $\mathrm{eu}^{2} /$ in $^{5}$ & POTAMOGETONETEA (c) \\
\hline Fontinalis antipyretica & 23 & 11 & -52.2 & in $^{\prime}$ & Ranunculion fluitantis (c) \\
\hline Myriophyllum alterniflorum & 32 & 15 & -53.1 & meso $^{1,3}$ & Callitricho-Myriophylletum (d) \\
\hline Potamogeton crispus & 62 & 25 & -59.7 & (meso-)eu ${ }^{5,6} /$ in $^{\prime}$ & POTAMOGETONETEA (c) \\
\hline Ranunculus fluitans & 16 & 6 & -62.5 & $\mathrm{eu}^{4, /}$ & Ranunculetum fluitantis (c) \\
\hline Ranunculus aquatilis agg. & 80 & 30 & -62.5 & meso ${ }^{1,4} / \mathrm{eu}^{3}$ & $\begin{array}{l}\text { Ranunculion fluitantis (c), } \\
\text { Callitricho-Myriophylletum (d) }\end{array}$ \\
\hline Potamogeton natans & 103 & 35 & -66.0 & $\pm \mathrm{meso}^{2} / \mathrm{eu}^{\mathrm{b}}$ & POTAMOGETONETEA (c) \\
\hline Myriophyllum verticillatum & 3 & 1 & -66.7 & meso-eu ${ }^{3,4}$ & Nymphaeetalia (c) \\
\hline Potamogeton berchtoldii & 3 & 1 & -66.7 & meso-eu ${ }^{2,5}$ & Potamogetonetalia (c) \\
\hline Potamogeton lucens & 37 & 10 & -73.0 & meso-eu' & $\begin{array}{l}\text { Potamogetonetum lucentis (c), } \\
\text { Nymphaeion albae (d) }\end{array}$ \\
\hline Callitriche hermaphroditica & 4 & 1 & -75.0 & oligo-meso ${ }^{3}$ & - \\
\hline Isolepis fluitans & 4 & 1 & -75.0 & oligo-meso $^{2}$ & - \\
\hline Potamogeton perfoliatus & 42 & 10 & -76.2 & meso-eu ${ }^{2,6}$ & $\begin{array}{l}\text { Potamogetonetum lucentis (c), } \\
\text { Nymphaeion albae (d) }\end{array}$ \\
\hline Zannichellia palustris & 14 & 3 & -78.6 & $\mathrm{eu}^{5,1}$ & Ranunculo-Sietum (d) \\
\hline Hippuris vulgaris & 3 & 0 & -100.0 & meso(-eu) ${ }^{3,1}$ & Ranunculo-Sietum (d) \\
\hline Potamogeton compressus & 3 & 0 & -100.0 & $\pm \mathrm{eu}^{2,4,5}$ & Potamogetonetalia (c) \\
\hline Nymphaea alba & 4 & 0 & -100.0 & in $^{3,4}$ & Myriophyllo-Nupharetum (c) \\
\hline Ranunculus circinatus & 4 & 0 & -100.0 & meso-eu ${ }^{3,5}$ & $\begin{array}{l}\text { Potamogetonion lucentis (c), } \\
\text { Nymphaeion albae (d) }\end{array}$ \\
\hline Potamogeton obtusifolius & 5 & 0 & -100.0 & meso $^{2,6}$ & Potamogetonion graminei (c) \\
\hline Juncus bulbosus fluitans & 9 & 0 & -100.0 & oligo $^{2}$ & Potamogetonion graminei $(\mathrm{d})$ \\
\hline Potamogeton alpinus & 18 & 0 & -100.0 & \pm meso 3,5 & $\begin{array}{l}\text { Potamogetonion graminei (c), } \\
\text { Callitricho-Myriophylletum (d) }\end{array}$ \\
\hline Potamogeton friesii & 32 & 0 & -100.0 & meso-eu ${ }^{2,6}$ & Potamogetonion pusilli (c) \\
\hline
\end{tabular}


The diversity decline in the macrophyte vegetation of north-west German streams and rivers over the last six decades is paralleled by global losses in the diversity of species in rivers (Millennium Ecosystem Assessment 2005), losses in the phytodiversity of European surface waters (e.g. Sand-Jensen et al. 2000, Schütz et al. 2008, Gołdyn 2010) and terrestrial systems in northern Germany (Meyer et al. 2010, Wesche et al. 2012, Leuschner et al. 2013). These studies identify eutrophication as one of the main drivers of vegetation change in the cultural landscapes since the 1950s. Since the 1980s, the nutrient status of the running waters of north-west Germany shows some improvement with more or less significant reductions in the nitrogen and phosphorus loads (Schulz 1999, Behrendt et al. 2002). These more recent developments might be reflected in the slight decrease in the EIV for nutrients since the 1980s; it appears that the vegetation is responding only slowly to the achievements.

The fact that current-intolerant species (Nymphaea alba, Ranunculus circinatus) could no longer be found in the investigated water courses in 2010/2011 indicates that sheltered inlets and small bays with calm water have disappeared, thus hinting at structural impoverishment of the riverbeds. The decline in plot-level species richness and diversity is assumed to be a consequence of increased disturbance, for example by construction or maintenance works. Increased disturbance is also indicated by the relative increase in summergreen species (including the lemnids and some nymphaeids) with the concurrent decline in evergreen species (the batrachids and most potamids), by the increase in R-strategists, as well as by the decrease in the mean SLA over the last six decades. Supporting this, Baattrup-Pedersen et al. (2002) found a higher proportion of R-strategists and a lower species richness and diversity in reaches, where weed-cutting is practiced when comparing weed-cut and uncut stream reaches.

\section{Future outlook}

The effects of climatic change can hardly be predicted. Warmer winters will probably favour the arrival of alien species, altering aquatic communities. In an artificially warmed river in North Rhine-Westphalia, a number of neophytic species became established and seems to be an addition to the local species pool, without causing harm to the native flora (Hussner \& Lösch 2005). Experiments by Mckee et al. (2002) showed that the exotic macrophyte Lagarosiphon major profited more from an increased water temperature than species established in Britain. Phytoplankton and algal growth might also be enhanced by warmer temperatures. Alahuhta et al. (2011) speculated referring to a modelling study for Finland that at higher temperatures emergent macrophytes might in many cases overgrow submerged vegetation. Elevated carbon dioxide concentrations might also favour 
macrophytes that are not capable of using bicarbonate as a carbon source (Johnson et al. 2009) such as for example Fontinalis antipyretica (Gessner 1959).

To reverse the diversity decline in river macrophytes, the homogenization of their habitats has to be reversed. Renaturalization measures aiming at the recreation of richly structured water courses with meanders, side arms, sheltered bays and shallow transition zones to floodplain areas need to go hand in hand with continuing efforts to reduce the nutrient inflows from the catchments. An extensive management of low-lying farmland renders intensive drainage and maintenance of the water courses unnecessary. Weed-cutting may be minimized and carried out in a gentle manner for example with a mowing bucket at ecologically sound dates (in autumn after fruit formation). Eutrophication can only be controlled if both, nitrogen and phosphorus inputs are reduced, considering also that phosphorus depositions may be stored in anoxic sediments as "internal loading" for decades (Conley et al. 2009) and that nitrogen has residence times of up to 30 years in the groundwater (Umweltbundesamt 2013). Impacts from intensive land use would in some cases be reduced if riparian buffer strips of at least $5 \mathrm{~m}$ width were established (Gunkel 1996). Jahn \& Dembinski (2000) estimated costs for the revitalization of two small rivers in Lower Saxony and arrived at 23,000-33,000 € $\mathrm{km}^{-1}$ mainly accounting for land extensification and also for the regeneration of a natural riverbed morphology to restore natural runoff dynamics.

In this way, specialist and less robust species, having once been much more abundant in north-west German running waters, might be able to become more distributed again. The reestablishment of locally extinct macrophyte species in suitable habitats is possible by reintroducing plants preferably from autochthonous populations (Kaplan et al. 1998), also paying attention to natural growth areas as for example the Ranunculo-Sietum community being typical for rhithral reaches and the Potamogetonetum lucentis growing in more or less potamal reaches. Regeneration processes like this cannot be expected to take less time than the decades of decrease took. In streams of the Donau catchment in southern Germany, an improvement in the water quality of a reach formerly influenced by sewage discharge was reflected in the macrophyte vegetation only after 15 years (Veit \& Kohler 2003). Conserving the phytodiversity of streams and rivers is essential to keep the ecosystems functioning, not least for the benefit of humans. 


\section{References}

Alahuhta, J., J. Heino \& M. Luoto (2011): Climate change and the future distributions of aquatic macrophytes across boreal catchments. Journal of Biogeography 38: 383393.

Baattrup-Pedersen, A., S.E. Larsen \& T. Riis (2002): Log-term effects of stream management on plant communities in two Danish lowland streams. Hydrobiologia 481: 33-45.

Behrendt, H., M. Kornmilch, D. Opitz, O. Schmoll \& G. Scholz (2002): Estimation of the nutrient inputs into river systems - experiences from German rivers. Regional Environmental Change 3(1-3): 107-117.

Casper, S.J. \& H.D. Krausch (1980): Pteridophyta und Anthophyta, 1. Teil: Lycopodiaceae bis Orchidaceae. In: H. Ettl, J. Gerloff \& H. Heynig (edts): Süsswasserflora von Mitteleuropa 23. Fischer, Stuttgart: 403 p.

Casper, S.J. \& H.D. Krausch (1981): Pteridophyta und Anthophyta, 2. Teil: Saururaceae bis Asteraceae. In: H. Ettl, J. Gerloff \& H. Heynig (edts): Süsswasserflora von Mitteleuropa 24. Fischer, Stuttgart: 539 p.

Chytrý, M. (2011): Vegetace České republiky 3. Vodní a mokřadní vegetace [Vegetation of the Czech Republic 3. Aquatic and wetland vegetation]. Academia, Prague: $827 \mathrm{p}$.

Conley, D.J., H.W. Paerl, R.W. Howarth, D.F. Boesch, S.P. Seitzinger, K.E. Havens, C. Lancelot \& G.E. Likens (2009): Controlling eutrophication: nitrogen and phosphorus. Science 323(5917): 1014-1015.

Garniel, A. (2008): Wasserpflanzen der Fließgewässer und Gräben, Informationen zum Verständnis ihrer Lebensstrategien als Grundlage für Erhaltungs- und Fördermaßnahmen in Schleswig-Holstein und Hamburg. Berichte des Botanischen Vereins zu Hamburg 24: 1-221.

Gessner, F. (1959): Hydrobotanik, die physiologischen Grundlagen der Pflanzenverbreitung im Wasser, Bd. 2: Stoffhaushalt. VEB Deutscher Verlag der Wissenschaften, Berlin: $701 \mathrm{~S}$.

Gołdyn, H. (2010): Changes in plant species diversity of aquatic ecosystems in the agricultural landscape in West Poland in the last 30 years. Biodiversity and Conservation 19(1): 61-80.

Gunkel, G. (1996): Renaturierung kleiner Fließgewässer. Fischer, Jena: 471 p.

Hussner, A. \& R. Lösch (2005): Alien aquatic plants in a thermally abnormal river and their assembly to neophyte-dominated macrophyte stands (River Erft, NorthrhineWestphalia). Limnologica 35(1): 18-30.

Jahn, W. \& M. Dembinski (2000): Vergleich von Makrozoobenthos und Gewässerstruktur in zwei Fließgewässern im Hinblick auf den Umfang erforderlicher Maßnahmen zur naturnahen Umgestaltung (naturräumliche Region Lüneburger Heide und Wendland; nordöstliches Niedersachsen). Limnologica 30(2): 131-136.

Johnson, A.C., M.C. Acreman, M.J. Dunbar, S.W. Feist, A.M. Giacomello, R.E. Gozlan, S.A. Hinsley, A.T. Ibbotson, H.P. Jarvie, J.I. Jones, M. Longshaw, S.C. Maberly, T.J. Marsh, C. Neal, J.R. Newman, M.A. Nunn, R.W. Pickup, N.S. Reynard, C.A. Sullivan, J.P. Sumpter \& R.J. Williams (2009): The British river of the future: how climate change and human activity might affect two contrasting river ecosystems in England. Science of the Total Environment 407(17): 4787-4798.

Kaplan, D., T. Oron \& M. Gutman (1998): Development of macrophytic vegetation in the Agmon wetland of Israel by spontaneous colonization and reintroduction. Wetlands Ecology and Management 6(2-3): 143-150. 
Kutscher, G. (1984): Verbreitung und Ökologie höherer Wasserpflanzen in Fließgewässern der Schwäbischen Alb - dargestellt an den Flüssen Bära, Schmiecha, Lauchert, Zwiefalter Ach und Große Lauter. Dissertation, Technische Universität München: $289 \mathrm{p}$.

Leuschner, C., K. Wesche, S. Meyer, B. Krause, K. Steffen, T. Becker \& H. Culmsee (2013): Veränderungen und Verarmung in der Offenlandvegetation Norddeutschlands seit den 1950er Jahren: Wiederholungsaufnahmen in Äckern, Grünland und Fließgewässern. Berichte der Reinhold-Tüxen-Gesellschaft (RTG) 25: 166-182.

Mckee, D., K. Hatton, J.W. Eaton, D. Atkinson, A. Atherton, I. Harvey \& B. Moss (2002): Effects of simulated climate warming on macrophytes in freshwater microcosm communities. Aquatic Botany 74(1): 71-83.

Meyer, S., B. Krause, K. Wesche \& C. Leuschner (2010): Changes in Central German arable plant communities over the last 50 years: a semi-quantitative study. Proceedings of 15th EWRS symposium (Kapsvoár, Hungary): 135-136.

Millennium Ecosystem Assessment (2005): Ecosystems and human well-being - Wetlands and water synthesis. World Resources Institute, Washington DC: 68 p.

Preising, E., H.-C. Vahle, D. Brandes, H. Hofmeister, J. Tüxen \& H.E. Weber (1990): Die Pflanzengesellschaften Niedersachsens - Bestandsentwicklung, Gefährdung und Schutzprobleme: Wasser- und Sumpfpflanzengesellschaften des Süßwassers. Naturschutz und Landschaftspflege in Niedersachsen 20/8: 47-161.

Preston, C.D. (1995): Pondweeds of Great Britain and Ireland. Botanical Society of the British Isles Handbook 8: 1-350.

Sand-Jensen, K., T. Riis, O. Vestergaard \& S.E. Larsen (2000): Macrophyte decline in Danish lakes and streams over the past 100 years. Journal of Ecology 88(6): 10301040.

Schulz, F. (1999): Trendauswertung der stofflichen Belastung schleswig-holsteinischer Fließgewässer. In: Landesamt für Natur und Umwelt Schleswig-Holstein, Jahresbericht 1999, Flintbek: 59-65.

Schütz, W., U. Veit \& A. Kohler (2008): The aquatic vegetation of the Upper Danube river past and present. Large Rivers 162: 167-191.

Tiedemann, H. (1982): Wasserpflanzen und Wasserpflanzengesellschaften als Bioindikatoren in Industrie- und Hafenrandgebieten Hamburgs - Makrophyten. Dissertation, Hamburg: $181 \mathrm{p}$.

Umweltbundesamt (2013): http://www.umweltbundesamt-daten-zurumwelt.de/umweltdaten/public/theme.do?nodeldent=2873 [28.04.2013]

Veit, U. \& A. Kohler (2003): Long-term study of the macrophytic vegetation in the running waters of the Friedberger Au (near Augsburg, Germany). Large Rivers 14: 65-86.

Wesche, K., B. Krause, H. Culmsee \& C. Leuschner (2012): Fifty years of change in Central European grassland vegetation: large losses in species richness and animalpollinated plants. Biological Conservation 150: 76-85. 
Appendix 
Table 2.2 Affinity of the 31 most abundant macrophyte species to 28 physical, chemical or river morphological parameters. Indicated are environmental parameters with significantly higher value (black fields) or significantly lower value (white fields) in plots with presence of the target species than in plots with the species' absence. Grey field $=$ no significant difference between habitats with and without the species, ${ }^{*}=p<0.05,{ }^{* *}=p<0.01,{ }^{* * *}=p<0.001$. Figures give the mean of the variable for all plots with the species' presence. Wat. $=$ Water, Sed. = Sediment

\begin{tabular}{|c|c|c|c|c|c|c|c|c|c|c|c|c|c|c|}
\hline $\begin{array}{l}\text { Macrophyte } \\
\text { species (no. of } \\
\text { plots) }\end{array}$ & $\begin{array}{l}\text { Current } \\
\text { velocity } \\
{\left[\mathrm{cm} \mathrm{s}^{-1}\right]}\end{array}$ & $\begin{array}{l}\text { Depth } \\
\text { [m] }\end{array}$ & $\begin{array}{l}\text { Anthrop. } \\
\text { influence }\end{array}$ & $\begin{array}{l}\text { Wat. } \\
\text { pH }\end{array}$ & $\begin{array}{l}\text { Sed. } \\
\text { pH }\end{array}$ & $\begin{array}{l}\text { Sed. } C_{\text {tot }} \\
{[\mathrm{mmol} / \mathrm{g}]}\end{array}$ & $\begin{array}{l}\text { Sed. Corg } \\
\text { [mmol/g] }\end{array}$ & $\begin{array}{l}\text { Wat. } \mathrm{NH}_{4} \\
{[\mathrm{mg} / \mathrm{l}]}\end{array}$ & $\begin{array}{l}\text { Wat. } \mathrm{NO}_{3} \\
{[\mathrm{mg} / \mathrm{l}]}\end{array}$ & $\begin{array}{l}\text { Sed. } N_{\text {tot }} \\
{[\mathrm{mmol} / \mathrm{g}]}\end{array}$ & $\begin{array}{l}\text { Sed. } \mathrm{C} / \mathrm{N} \\
\text { ratio }\end{array}$ & $\begin{array}{l}\text { Sed. N/P } \\
\text { ratio }\end{array}$ & $\begin{array}{l}\text { Wat. } \mathrm{PO}_{4} \\
\text { [mg/l] }\end{array}$ & $\begin{array}{l}\text { Sed. } \\
\text { Presin } \\
\text { [umol/al }\end{array}$ \\
\hline Myri. alte. (16) & $* * 17.5$ & & $\star * 2.9$ & & **6.7 & $\star \star 0.53$ & ** 0.47 & $* * 0.03$ & & * 0.06 & & & ${ }^{*} 0.01$ & $\star \star * 1.67$ \\
\hline Ranu. pelt. (28) & & ${ }^{*} 0.6$ & $* 3.1$ & & 6.8 & & & & & & & & & $\star \star \star \star * 2.24$ \\
\hline Call. hamu.(42) & & $\pi \star 0$ & 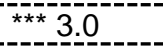 & & 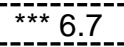 & & & $\star * 0.08$ & 2.91 & & & & $\begin{array}{l}* 02 \\
*\end{array}$ & \\
\hline Beru. erec. (57) & $\star * 17.4$ & $\star \star \star x-6$ & 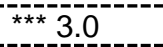 & & $\star \star-7.0$ & & $\star \star 1.71$ & * & & $\star * 0.12$ & $* 10.35$ & & & 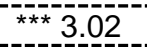 \\
\hline Glyc. flui. (24) & & 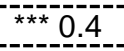 & 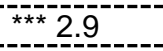 & & $\star \star \star \star-6-6$ & & & & & & & & & \\
\hline Font. anti. (20) & ** 18.9 & 0.8 & 3.2 & & & & & $\div \quad 0.07$ & 3.45 & 0.13 & & & & $\times 2.54$ \\
\hline \multirow{2}{*}{\multicolumn{15}{|c|}{ Spar. erec. (90) }} \\
\hline \multirow{2}{*}{\multicolumn{8}{|c|}{$\begin{array}{l}\text { Elod. cana. (71) } \\
\text { Call. obtu. (12) }\end{array}$}} & & & & & & & \\
\hline & & & & & & & & ${ }^{*} 0.31$ & & & & & & 7.22 \\
\hline \multirow{2}{*}{\multicolumn{15}{|c|}{ Call. plat. (108) }} \\
\hline \multicolumn{12}{|l|}{ Phal. arun. (161) } & & & \\
\hline \multirow{2}{*}{\multicolumn{15}{|c|}{ Pota. perf. (12) }} \\
\hline & & & & & & & & & & & & & & \\
\hline \multirow{2}{*}{\multicolumn{15}{|c|}{$\begin{array}{l}\text { Pota. pusi. (10) } \\
\text { Pota nata. (36) }\end{array}$}} \\
\hline & & & $* * * 3.5$ & * 8.0 & & *2.04 & * 1.98 & $* * * 0.28$ & $\star 1.73$ & & * 13.56 & * 136.01 & & \\
\hline \multicolumn{15}{|l|}{ Utri. vulg. (10) } \\
\hline \multirow{2}{*}{\multicolumn{15}{|c|}{$\begin{array}{l}\text { Buto. umbe. (35) } \\
\text { Lemn. tris. (32) }\end{array}$}} \\
\hline & & & & & & & & & & & & & & \\
\hline \multicolumn{15}{|l|}{ Pota. pect. (36) } \\
\hline \multirow{2}{*}{\multicolumn{15}{|c|}{$\begin{array}{l}\text { Pota. luce. (13) } \\
\text { Lemn. gibb. (31) }\end{array}$}} \\
\hline \multirow{2}{*}{\multicolumn{15}{|c|}{$\begin{array}{l}\text { Lemn. gibb. (31) } \\
\text { Spar. emer. (169) }\end{array}$}} \\
\hline & & & & & & & & & & & & & & \\
\hline \multirow{2}{*}{\multicolumn{15}{|c|}{$\begin{array}{l}\text { Cera. deme. (23) } \\
\text { Lemn. mino. (192) }\end{array}$}} \\
\hline \multirow{2}{*}{\multicolumn{15}{|c|}{ Hydr. mors. (12) }} \\
\hline & & & & & & & & & & & & & & \\
\hline \multicolumn{15}{|l|}{ Pota. cris. (27) } \\
\hline \multicolumn{15}{|l|}{ Spir. poly. (107) } \\
\hline $\begin{array}{l}\text { Elod. nutt. (71) } \\
\text { Nuph. lute. (93) }\end{array}$ & & $\begin{array}{l}* * 1.4 \\
* * * 1.3\end{array}$ & $* * * 3.4$ & & & $\begin{array}{l}2.98 \\
* * 21 \\
*\end{array}$ & $\begin{array}{l}2.85 \\
* * 2.12\end{array}$ & ${ }^{*} 0.20$ & $\star 1.99$ & $\begin{array}{l}{ }^{* *} \\
* *\end{array}$ & 15.51 & $* 61.54$ & & $\begin{array}{l}* 7.75 \\
* 7.704 \\
* * 7.04\end{array}$ \\
\hline $\begin{array}{l}\text { Sagi. sagi. (83) } \\
\text { Myri. spic. (23) }\end{array}$ & $\star \star * \star 78$ & $\begin{array}{lll}* * * 1.5 \\
* * 1.6\end{array}$ & $* 3.6$ & & $\begin{array}{l}* * 7.3 \\
* * 7.3 \\
* * 7.3\end{array}$ & & & $\begin{array}{l}* 0.27 \\
* \quad 0.08\end{array}$ & & & & & & $\begin{array}{l}* 10.11 \\
* * 459 \\
* * 470\end{array}$ \\
\hline & & & & & & & & & & & & & & \\
\hline
\end{tabular}


Table 2.2 continued

\begin{tabular}{|c|c|c|c|c|c|c|c|c|c|c|c|c|c|c|}
\hline $\begin{array}{l}\text { Macrophyte } \\
\text { species (no. of } \\
\text { plots) }\end{array}$ & $\begin{array}{l}\text { Wat. S } \\
\text { [mg/l] }\end{array}$ & $\begin{array}{l}\text { Wat. Ca } \\
{[\mathrm{mg} / \mathrm{l}]}\end{array}$ & $\begin{array}{l}\text { Sed. Ca } \\
{[\mu \mathrm{mol} / \mathrm{g}]}\end{array}$ & $\begin{array}{l}\text { Wat. Mg } \\
{[\mathrm{mg} / \mathrm{l}]}\end{array}$ & $\begin{array}{l}\text { Sed. Mg } \\
{[\mu \mathrm{mol} / \mathrm{g}]}\end{array}$ & $\begin{array}{l}\text { Wat. K } \\
\text { [mg/l] }\end{array}$ & $\begin{array}{l}\text { Sed. K } \\
{[\mu \mathrm{mol} /} \\
\mathrm{g}]\end{array}$ & $\begin{array}{l}\text { Wat. } \\
\mathrm{Na} \\
{[\mathrm{mg} / \mathrm{l}]}\end{array}$ & $\begin{array}{l}\text { Sed. } \mathrm{Na} \\
{[\mu \mathrm{mol} / \mathrm{g}]}\end{array}$ & $\begin{array}{l}\text { Sed. CEC } \\
{[\mu \mathrm{mol} / \mathrm{c} / \mathrm{g}]}\end{array}$ & $\begin{array}{l}\text { Wat. } \\
\mathrm{Fe} \\
{[\mathrm{mg} / \mathrm{l}]}\end{array}$ & $\begin{array}{l}\text { Sed. Fe } \\
{[\mu \mathrm{mol} / \mathrm{g}]}\end{array}$ & $\begin{array}{l}\text { Wat. Al } \\
\text { [mg/l] }\end{array}$ & $\begin{array}{l}\text { Sed. Al } \\
{[\mu \mathrm{mol} / \mathrm{g}]}\end{array}$ \\
\hline Myri. alte. (16) & & $* 23.50$ & $* \star 23.98$ & *** 5.58 & ** 2.43 & & ** 0.63 & & *** 0.80 & 37.97 & & 0.41 & & \\
\hline Ranu. pelt. (28) & & $x^{*}-15.78$ & 16.80 & $\times 3.09$ & $\star * 1.48$ & & $\star \star \star \star \star-50$ & & ${ }^{*} 1.05$ & 50.79 & & & & ${ }^{* *} 0.32$ \\
\hline Call. hamu.(42) & $\star \star 10.35$ & 22.08 & $\star \star \star \star-32.32$ & $\star 4.45$ & $4 * 3.04$ & & $\star 1.09$ & & $* 1.46$ & $\star \star \star x-08$ & & & & $* 4 * 01$ \\
\hline Beru. erec. (57) & & & 51.47 & & ** 3.92 & 3.56 & & * ${ }^{*} 21.4$ & $* 1.87$ & & $\star * 13$ & $* 3.20$ & 0.01 & $\therefore \quad 031$ \\
\hline Glyc. flui. (24) & & & 4253 & & & & & & & & & $x+86$ & & \\
\hline Font. anti. (20) & & & & $* 1206$ & & & & & & & 0.06 & & & \\
\hline \multirow{2}{*}{\multicolumn{15}{|c|}{$\begin{array}{l}\text { Spar. erec. (90) } \\
\text { Flod. cana }(71)\end{array}$}} \\
\hline & 15.01 & $\star \quad 33.52$ & & & & & & & 1.87 & & * 0.16 & & & \\
\hline Call. obtu. (12) & & $\begin{array}{l}* 2931 \\
\end{array}$ & & 4.88 & & & & & & & & & & \\
\hline Call. plat. (108) & $\star \star \star-16.77$ & $4 \times 33$ & & $* \star-6 \overline{3}$ & & & & **26.2 & & * 127.13 & 0.26 & 6.34 & & 0.52 \\
\hline \multicolumn{15}{|l|}{ Phal. arun. (161) } \\
\hline \multirow{2}{*}{\multicolumn{15}{|c|}{$\begin{array}{l}\text { Phra. aust. (26) } \\
\text { Pota. perf. (12) }\end{array}$}} \\
\hline & & & & & & & & & & & & & & \\
\hline \multicolumn{15}{|l|}{ Pota. pusi. (10) } \\
\hline \multirow{2}{*}{\multicolumn{15}{|c|}{$\begin{array}{l}\text { Pota. nata. (36) } \\
\text { Utri. vulg. (10) }\end{array}$}} \\
\hline & & & & & & & & & & & & & & \\
\hline \multirow{2}{*}{\multicolumn{15}{|c|}{$\begin{array}{l}\text { Buto. umbe. (35) } \\
\text { Lemn. tris. (32) }\end{array}$}} \\
\hline & & & & & & & & & & & & & & \\
\hline Pota. pect. (36) & * 45.17 & $* * * 69.44$ & & $* * * 16.43$ & & & & & & 13943 & 0.13 & $* 1.04$ & & \\
\hline Pota. luce. (13) & & & & $\begin{array}{r}* 5.09 \\
\end{array}$ & & & & & & & & & $x<0.01$ & \\
\hline \multicolumn{15}{|l|}{ Lemn. gibb. (31) } \\
\hline Spar. emer. (169) & $\star \star \star \star 23.93$ & $\star \star \star \star x-02$ & & 9.03 & & & & & * 2.11 & 119.34 & $* * * 0.17$ & & & \\
\hline \multicolumn{15}{|l|}{ Cera. deme. (23) } \\
\hline \multicolumn{15}{|l|}{$\begin{array}{l}\text { Lemn. mino. (192) } \\
\text { Hydr. mors. (12) }\end{array}$} \\
\hline \multirow{2}{*}{\multicolumn{15}{|c|}{$\begin{array}{l}\text { Pota. cris. (27) } \\
\text { Spir. poly. (107) }\end{array}$}} \\
\hline & & & & & & & & & & & & & & \\
\hline \multirow{4}{*}{$\begin{array}{l}\text { Elod. nutt. (71) } \\
\text { Nuph. lute. (93) } \\
\text { Sagi. sagi. (83) } \\
\text { Myri. spic. (23) }\end{array}$} & $\star \star \star * 2132$ & & & & & & & & & & & & $<<0.01$ & \\
\hline & & * 47.47 & $* * 69.16$ & & $* * * 5.03$ & & ***1.5 & & 20256 & & 0.22 & $* * 6.67$ & $x<0.01$ & $4 \star x<08$ \\
\hline & & & & & & & & & $\begin{array}{l}* .58 \\
*-5\end{array}$ & 177.75 & $* * * 0.33$ & $* * 10.61$ & & \\
\hline & *** 35.20 & *** 54.16 & ** 81.72 & *** 10.38 & 7.62 & & & ${ }^{\star \star *} 65.3$ & ${ }^{* *} 5.07$ & & ** 0.09 & & & ${ }^{\star *} 0.02$ \\
\hline
\end{tabular}


Table 2.5 Correlations after Spearman of environmental variables with the DCA axes 1 and 2. Only variables correlating at $r> \pm 0.20$ with one of the axes are shown. Significance values were not derived from a permutation test and are only indicated as a guidance

\begin{tabular}{|c|c|c|c|c|}
\hline Environmental variable & r DCA axis 1 & $\mathbf{p}$ & r DCA axis 2 & $\mathbf{p}$ \\
\hline Depth [m] & -0.60 & $<0.001$ & 0.02 & 0.735 \\
\hline Width [m] & -0.49 & $<0.001$ & -0.06 & 0.352 \\
\hline Current vel. [ $\left.\mathrm{cm} \mathrm{s}^{-1}\right]$ & 0.45 & $<0.001$ & 0.13 & 0.025 \\
\hline $\mathrm{NH}_{4}$ (Water) & -0.41 & $<0.001$ & 0.02 & 0.776 \\
\hline Anthropogenic influence & -0.37 & $<0.001$ & -0.12 & 0.045 \\
\hline Fe (Water) & -0.36 & $<0.001$ & -0.30 & $<0.001$ \\
\hline $\mathrm{Na}$ (Water) & -0.34 & $<0.001$ & 0.04 & 0.556 \\
\hline$P_{\text {resin }}$ (Sediment) & -0.33 & $<0.001$ & -0.12 & 0.041 \\
\hline CEC (Sediment) & -0.32 & $<0.001$ & 0.15 & 0.014 \\
\hline $\mathrm{Ca}$ (Sediment) & -0.30 & $<0.001$ & 0.18 & 0.003 \\
\hline $\mathrm{C}_{\text {org }}$ (Sediment) & -0.30 & $<0.001$ & 0.10 & 0.089 \\
\hline Mn (Water) & -0.30 & $<0.001$ & -0.17 & 0.004 \\
\hline $\mathrm{K}$ (Water) & -0.29 & $<0.001$ & -0.04 & 0.531 \\
\hline Fe (Sediment) & -0.28 & $<0.001$ & -0.03 & 0.573 \\
\hline $\mathrm{Na}$ (Water) & -0.27 & $<0.001$ & -0.02 & 0.708 \\
\hline K (Sediment) & -0.26 & $<0.001$ & 0.04 & 0.482 \\
\hline $\mathrm{N}$ (Sediment) & -0.25 & $<0.001$ & 0.10 & 0.099 \\
\hline $\mathrm{NO}_{3}$ (Water) & 0.24 & $<0.001$ & -0.18 & 0.002 \\
\hline Mn (Sediment) & -0.23 & $<0.001$ & -0.09 & 0.151 \\
\hline Mg (Sediment) & -0.23 & $<0.001$ & 0.10 & 0.088 \\
\hline Zn (Water) & -0.09 & 0.148 & -0.22 & $<0.001$ \\
\hline $\mathrm{pH}$ (Sediment) & -0.19 & 0.002 & 0.20 & $<0.001$ \\
\hline
\end{tabular}


Table 3.1 Sampled water courses by region and corresponding number of relevés

\begin{tabular}{|c|c|c|c|c|}
\hline Region & $\begin{array}{l}\text { Catch- } \\
\text { ment } \\
\text { basins }\end{array}$ & Streams / rivers & $\begin{array}{l}\text { No. of } \\
\text { relevés } \\
\text { period A } \\
\text { and } \\
\text { period C }\end{array}$ & $\begin{array}{l}\text { No. of } \\
\text { relevés } \\
\text { period } \\
\text { B }\end{array}$ \\
\hline $\begin{array}{l}1 \text { Ems-Hunte moraine } \\
\text { (western / central Lower } \\
\text { Saxony) }\end{array}$ & $\begin{array}{l}\text { Ems, } \\
\text { Weser }\end{array}$ & $\begin{array}{l}\text { Bornbach, Bruchgraben, Dadau, } \\
\text { Dorflohne, Elze, Ems, Eyter, Flöthe, } \\
\text { Grawiede, Grenzkanal, Hase, Hunte, } \\
\text { Lohne, Lotterbeke, Mittelradde, } \\
\text { Steinhuder Meerbach, Strothe, Schwarze } \\
\text { Riede, Uchter Mühlenbach, Wagenfelder } \\
\text { Aue }\end{array}$ & 77 & 45 \\
\hline $\begin{array}{l}2 \text { Lüneburg Heath } \\
\text { (eastern Lower Saxony) }\end{array}$ & Weser & $\begin{array}{l}\text { Aue, Aschau, (Seehals-) Beeke, Berger } \\
\text { Bach, Böhme, Bokeler Bach, Bruchbach, } \\
\text { Emmerbach, Ilmenau, Kainbach, Kleine } \\
\text { Örtze, Kohlenbach, Knesebach, Lachte, } \\
\text { Lutter, Örtze, Schmalwasser, } \\
\text { Schwarzwasser, Wiehe, Wietze }\end{array}$ & 86 & 17 \\
\hline $\begin{array}{l}\text { with Aller lowlands } \\
\text { (eastern Lower Saxony) }\end{array}$ & Weser & $\begin{array}{l}\text { Aller, Allerkanal, Kleine Aller, Fuhse, Ise, } \\
\text { Westaue }\end{array}$ & 23 & 8 \\
\hline $\begin{array}{l}3 \text { Northern Harz foothills } \\
\text { (eastern Lower Saxony) }\end{array}$ & Weser & $\begin{array}{l}\text { Altenau, Erse, Fuhse, Ilse, Kanal-Ilse, } \\
\text { Lutter (Elm), Oker, Schiffgraben, } \\
\text { Schunter, Spring, Wabe, Warne }\end{array}$ & 75 & 1 \\
\hline $\begin{array}{l}\text { with Weser-Leine } \\
\text { uplands (southern } \\
\text { Lower Saxony, eastern } \\
\text { North Rhine- } \\
\text { Westphalia) }\end{array}$ & $\begin{array}{l}\text { Rhine, } \\
\text { Weser }\end{array}$ & $\begin{array}{l}\text { Beke, Emmer, Glenne, Grone, } \\
\text { Liesenbach, Niese, Oder }\end{array}$ & 16 & 7 \\
\hline $\begin{array}{l}4 \text { Eastern Holstein } \\
\text { moraine (eastern } \\
\text { Schleswig-Holstein) }\end{array}$ & $\begin{array}{l}\text { Baltic } \\
\text { Sea }\end{array}$ & $\begin{array}{l}\text { Behler Bach, effluent stream from } \\
\text { Stocksee to Nehmter Binnenau, Kossau, } \\
\text { Kührener Au, Schwentine, Tensfelder Au }\end{array}$ & 61 & 22 \\
\hline Total no. of relevés & & & 338 & 100 \\
\hline
\end{tabular}


Table 3.2 List of all hydrophytic species and related traits. (Strategy type: $\mathrm{c}=$ competitor, $\mathrm{s}=$ stress strategist, $r$ = ruderal strategist; pollination type: an = anemogamy, au = autogamy, hy = hydrogamy, zo = zoogamy (in = insects, $\mathrm{sn}=$ snails); leaf longevity: ev = evergreen, $\mathrm{su}=$ summergreen. Red List status in Germany: 2 = endangered, $3=$ vulnerable, $V=$ near threatened, $G=$ data missing, but assumed to be vulnerable)

\begin{tabular}{|c|c|c|c|c|}
\hline Species & $\begin{array}{l}\text { Strategy } \\
\text { type (CRS) }\end{array}$ & Pollination type & $\begin{array}{l}\text { Leaf } \\
\text { longevity }\end{array}$ & $\begin{array}{l}\text { Red List } \\
\text { status }\end{array}$ \\
\hline Callitriche hamulata & crs & an, hy, au & ev & - \\
\hline Callitriche hermaphroditica & - & hy, au & ev & $G$ \\
\hline Callitriche palustris agg. & - & - & - & - \\
\hline Ceratophyllum demersum & sss & hy & ev & - \\
\hline Chiloscyphus polyanthos (liverwort) & - & - & - & - \\
\hline Elodea canadensis & css & hy & ev & - \\
\hline Elodea nuttallii & css & hy & ev & - \\
\hline Fontinalis antipyretica (moss) & - & - & - & $\mathrm{V}$ \\
\hline Groenlandia densa & sss & an, hy, au & su & 2 \\
\hline Helosciadium inundatum & css & au, zo (in) & su & 2 \\
\hline Hippuris vulgaris & css & an & su & 3 \\
\hline Hydrocharis morsus-ranae & css & zo (in) & su & 3 \\
\hline Isolepis fluitans & css & an & ev & 2 \\
\hline Juncus bulbosus fluitans & crs & an & ev & - \\
\hline Lemna gibba & rss & an, hy, au, zo (in, sn) & su & - \\
\hline Lemna minor & rss & an, hy, au, zo (in, sn) & su & - \\
\hline Lemna trisulca & sss & an, hy, au, zo (in, sn) & su & - \\
\hline Leptodictyum riparium (moss) & - & - & - & - \\
\hline Luronium natans & sss & au, zo (in) & ev & 2 \\
\hline Myriophyllum alterniflorum & css & an & ev & 2 \\
\hline Myriophyllum spicatum & css & an, au, zo (in) & ev & - \\
\hline Myriophyllum verticillatum & css & an, hy & ev & - \\
\hline Nuphar lutea & css & zo (in) & su & - \\
\hline Nymphaea alba & $\operatorname{css}$ & au, zo (in) & su & - \\
\hline Platyhypnidium riparioides (moss) & - & - & - & - \\
\hline Potamogeton acutifolius & sss & an & ev & 3 \\
\hline Potamogeton alpinus & css & an & ev & 3 \\
\hline Potamogeton angustifolius & - & - & ev & 2 \\
\hline Potamogeton berchtoldii & rss & an, hy & ev & $\mathrm{V}$ \\
\hline Potamogeton compressus & sss & an, hy & ev & 2 \\
\hline Potamogeton crispus & css & an & ev & - \\
\hline Potamogeton filiformis & rss & an, hy, au & ev & 2 \\
\hline Potamogeton friesii & sss & an, hy & ev & 2 \\
\hline Potamogeton gramineus & css & an, hy & ev & 2 \\
\hline Potamogeton lucens & css & an, hy & ev & $\mathrm{V}$ \\
\hline Potamogeton natans & crs & an & ev & - \\
\hline Potamogeton nodosus & crs & an, hy & ev & V \\
\hline Potamogeton obtusifolius & sss & an, au & ev & 3 \\
\hline Potamogeton pectinatus & rss & an, hy & ev & - \\
\hline Potamogeton perfoliatus & css & an, hy & ev & V \\
\hline Potamogeton polygonifolius & crs & an, hy & ev & 3 \\
\hline
\end{tabular}




\begin{tabular}{lllll}
\hline Species & $\begin{array}{l}\text { Strategy } \\
\text { type (CRS) }\end{array}$ & Pollination type & $\begin{array}{l}\text { Leaf } \\
\text { longevity }\end{array}$ & $\begin{array}{l}\text { Red List } \\
\text { status }\end{array}$ \\
\hline Potamogeton praelongus & css & an, hy & ev & 2 \\
Potamogeton pusillus & rss & an, hy & ev & V \\
Potamogeton trichoides & sss & an, hy & ev & 3 \\
Potamogeton crispus x perfoliatus & - & - & - & - \\
Ranunculus aquatilis agg. & - & - & - & - \\
Ranunculus circinatus & css & au, zo (in) & ev & V \\
Ranunculus fluitans & css & au & ev & V \\
Ranunculus hederaceus & css & au, zo (in) & ev & 2 \\
Ranunculus trichophyllus & css & au, zo (in) & ev & V \\
Sparganium emersum & css & an & ev & - \\
Sparganium natans & css & an & ev & 2 \\
Spirodela polyrhiza & rss & an, hy, au, zo (in, sn) & su & - \\
Utricularia neglecta & sss & zo (in) & su & 3 \\
Utricularia vulgaris & sss & zo (in) & su & 3 \\
Wolffia arrhiza & sss & au & su & 2 \\
Zannichellia palustris & sss & hy, au & ev & V \\
\hline
\end{tabular}

Table 3.3 Correlation of time (sampling date), the number of red-listed species per relevé, biotic traits and environmental variables with the DCA axes 1 and 2. The significance levels are not based on a randomization test; they are only given for indicating the strength of the relationships

\begin{tabular}{llrrrrr}
\hline Variable & $\begin{array}{l}\text { Correlation } \\
\text { type }\end{array}$ & $\mathbf{r}$ & DCA axis & r & \multicolumn{2}{c}{ DCA axis } \\
& \multicolumn{2}{c}{$\mathbf{1}$} & \multicolumn{2}{c}{$\mathbf{2}$} \\
\hline Time [year] & Spearman & 0.03 & $\mathrm{p}=0.665$ & 0.41 & $\mathrm{p}<0.001$ \\
Red-listed species / relevé & Spearman & -0.15 & $\mathrm{p}=0.011$ & -0.45 & $\mathrm{p}<0.001$ \\
Pleustophytic [\%] & Spearman & -0.44 & $\mathrm{p}<0.001$ & 0.27 & $\mathrm{p}<0.001$ \\
Potamid [\%] & Spearman & -0.17 & $\mathrm{p}=0.005$ & -0.53 & $\mathrm{p}<0.001$ \\
Batrachid [\%] & Pearson & 0.49 & $\mathrm{p}=0.001$ & -0.00 & $\mathrm{p}=0.999$ \\
Nymphaeid [\%] & Pearson & -0.29 & $\mathrm{p}<0.001$ & 0.05 & $\mathrm{p}=0.531$ \\
C-strategists [\%] & Pearson & 0.33 & $\mathrm{p}<0.001$ & -0.03 & $\mathrm{p}=0.591$ \\
R-strategists [\%] & Pearson & -0.17 & $\mathrm{p}=0.010$ & 0.19 & $\mathrm{p}=0.003$ \\
S-strategists [\%] & Pearson & -0.37 & $\mathrm{p}<0.001$ & -0.21 & $\mathrm{p}<0.001$ \\
Evergreen species [\%] & Spearman & 0.54 & $\mathrm{p}<0.001$ & -0.42 & $\mathrm{p}<0.001$ \\
SLA [m kg $^{-1}$ ] & Pearson & 0.21 & $\mathrm{p}<0.001$ & -0.59 & $\mathrm{p}<0.001$ \\
EIV for nitrogen & Pearson & -0.08 & $\mathrm{p}=0.197$ & -0.20 & $\mathrm{p}<0.001$ \\
EIV for soil reaction & Spearman & -0.33 & $\mathrm{p}<0.001$ & -0.16 & $\mathrm{p}=0.009$ \\
EIV for temperature & Pearson & -0.39 & $\mathrm{p}<0.001$ & -0.04 & $\mathrm{p}=0.534$ \\
Current velocity [cm s ${ }^{-1}$ ] & Spearman & 0.44 & $\mathrm{p}<0.001$ & -0.25 & $\mathrm{p}<0.001$ \\
\hline
\end{tabular}


Table 3.5 Changes in species richness and diversity between the 1950s and 2010/2011

\begin{tabular}{|c|c|c|c|c|c|c|c|}
\hline Diversity parameter & 1950s & $\begin{array}{l}2010 / \\
2011\end{array}$ & $\begin{array}{l}\text { Direction } \\
\text { of change }^{1}\end{array}$ & $\mathbf{Z}$ & $\begin{array}{l}\text { p Wilcoxon- } \\
\text { test }\end{array}$ & $T$ & p t-test \\
\hline Species richness / relevé & 4.7 & 3.8 & $\downarrow$ & -5.8 & $<0.001$ & & \\
\hline Red-listed species / relevé & 0.9 & 0.3 & $\downarrow$ & -8.9 & $<0.001$ & & \\
\hline Diversity (D) & 2.8 & 2.3 & $\downarrow$ & & & 5.4 & $<0.001$ \\
\hline
\end{tabular}

Table 3.7 Changes in proportions of life or growth forms between the 1950s and 2010/2011

\begin{tabular}{lrrllr}
\hline Life / growth form & 1950s & 2010/2011 & Change $^{1}$ & Z & p Wilcoxon-test \\
\hline Pleustophytic [\%] & 15.5 & 33.8 & $\uparrow$ & -8.2 & $<0.001$ \\
Vallisnerid [\%] & 10.8 & 18.0 & $\uparrow$ & -4.1 & $<0.001$ \\
Bryid [\%] & 4.3 & 5.3 & - & -0.1 & 0.924 \\
Myriophyllid [\%] & 4.3 & 4.2 & - & -0.7 & 0.477 \\
Elodeid [\%] & 10.0 & 9.1 & - & -0.2 & 0.845 \\
Peplid [\%] & 13.6 & 11.3 & $\downarrow$ & -2.1 & 0.040 \\
Isoetid [\%] & 0.4 & 0.0 & $\downarrow$ & -2.7 & 0.008 \\
Potamid [\%] & 19.6 & 7.7 & $\downarrow$ & -8.0 & $<0.001$ \\
Batrachid [\%] & 6.1 & 2.0 & $\downarrow$ & -5.9 & $<0.001$ \\
Nymphaeid [\%] & 15.3 & 8.6 & $\downarrow$ & -5.9 & $<0.001$ \\
\hline
\end{tabular}

${ }^{1} \downarrow=$ decrease, $\uparrow=$ increase

Table 3.10 Changes in biological and environmental traits between the 1950s, 1980s and 2010/2011

\begin{tabular}{|c|c|c|c|c|c|c|c|}
\hline Parameter & 1950s & 1980s & 2010 & $\begin{array}{l}\text { Main } \\
\text { effect }^{1}\end{array}$ & $\begin{array}{l}\text { Change }^{2} \\
\text { 1950s- } \\
\text { 1980s }\end{array}$ & $\begin{array}{l}\text { Change }^{2} \\
\text { 1980s- } \\
2010\end{array}$ & $\begin{array}{l}\text { Change }^{2} \\
1950 \text { s- } \\
2010\end{array}$ \\
\hline Pleustophytic [\%] & 20.9 & 26.2 & 38.7 & $S<0.001$ & - & $\uparrow^{* *}$ & $\uparrow^{* * *}$ \\
\hline Nymphaeid [\%] & 21.7 & 16.0 & 12.7 & $G<0.001$ & $\downarrow^{* *}$ & - & $\downarrow^{* * *}$ \\
\hline Potamid [\%] & 17.2 & 16.0 & 6.1 & $G<0.001$ & - & $\downarrow^{* *}$ & $\downarrow^{* * *}$ \\
\hline Batrachid [\%] & 5.0 & 2.3 & 1.0 & $G<0.001$ & $\downarrow^{*}$ & - & $\downarrow * * *$ \\
\hline C-strategists [\%] & 25.2 & 20.5 & 17.5 & $S<0.001$ & $\downarrow$ ** & $\downarrow^{*}$ & $\downarrow^{* * *}$ \\
\hline R-strategists [\%] & 9.9 & 14.7 & 14.9 & G $\quad 0.010$ & $\uparrow^{*}$ & - & $\uparrow^{* *}$ \\
\hline S-strategists [\%] & 64.8 & 64.9 & 67.6 & G $\quad 0.010$ & - & - & $\uparrow^{* *}$ \\
\hline Anemogamy [\%] & 39.8 & 42.7 & 34.6 & S $\quad 0.024$ & - & $\downarrow^{*}$ & - \\
\hline Hydrogamy [\%] & 27.2 & 23.7 & 27.6 & G $\quad 0.416$ & - & - & - \\
\hline Autogamy [\%] & 9.5 & 9.1 & 10.0 & G $\quad 0.479$ & - & - & - \\
\hline Zoogamy [\%] & 24.5 & 25.2 & 27.2 & G 0.509 & - & - & - \\
\hline Evergreen species [\%] & 65.8 & 59.6 & 48.8 & $S<0.001$ & - & $\downarrow^{*}$ & $\downarrow$ *** \\
\hline $\mathrm{SLA}\left[\mathrm{m}^{2} \mathrm{~kg}^{-1}\right]$ & 37.2 & 35.3 & 28.9 & S 0.001 & - & $\downarrow$ ** & $\downarrow^{* *}$ \\
\hline EIV for nitrogen & 6.0 & 6.4 & 6.3 & $G<0.001$ & $\uparrow^{* * *}$ & - & $\uparrow^{* * *}$ \\
\hline EIV for soil reaction & 6.6 & 6.8 & 6.6 & $S<0.001$ & $\uparrow^{* * *}$ & $\downarrow$ ** & - \\
\hline EIV for temperature & 5.7 & 5.6 & 5.7 & G $\quad 0.061$ & - & - & - \\
\hline
\end{tabular}

${ }^{1}$ Main effect: $\mathrm{S}=$ sphericity, $\mathrm{G}=$ Greenhouse-Geisser, ${ }^{2} \downarrow=$ decrease, $\uparrow=$ increase, ${ }^{*}=p<0.05$, ${ }^{* *}=p<0.01,{ }^{* * *}=p<0.001$ 


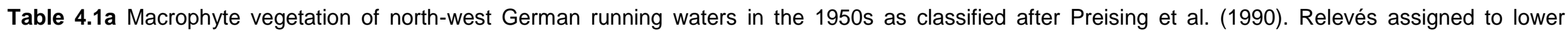
syntaxonomic levels than the class belong to several groups; 337 relevés are included. No specific character species is attributed to the Nymphaeion albae,

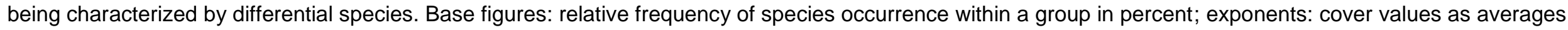
within groups

\begin{tabular}{|c|c|c|c|c|c|c|c|c|c|c|c|c|c|c|c|c|c|}
\hline $\begin{array}{l}\text { No. of species / relevé } \\
\text { No. of relevés }\end{array}$ & $\begin{array}{c}6.6 \\
336 \\
\text { Pota- } \\
\text { metea }\end{array}$ & $\begin{array}{l}6.4 \\
59 \\
\text { Pota- } \\
\text { meta- } \\
\text { lia }\end{array}$ & 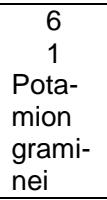 & $\begin{array}{l}5.2 \\
41 \\
\text { Pota- } \\
\text { mion } \\
\text { lucen- } \\
\text { tis }\end{array}$ & $\begin{array}{l}\quad 5.2 \\
\quad 40 \\
\text { Pota- } \\
\text { metum } \\
\text { lucen- } \\
\text { tis }\end{array}$ & $\begin{array}{c}9.6 \\
16 \\
\text { Pota- } \\
\text { mion } \\
\text { pusilli }\end{array}$ & $\begin{array}{c}6.2 \\
52 \\
\text { Nym- } \\
\text { phae- } \\
\text { etalia }\end{array}$ & $\begin{array}{l}3.5 \\
2 \\
\text { Hy- } \\
\text { dro- } \\
\text { cha- } \\
\text { rition } \\
\end{array}$ & $\begin{array}{l}6.9 \\
40 \\
\text { Nym- } \\
\text { phae- } \\
\text { ion } \\
\text { albae }\end{array}$ & \begin{tabular}{l}
\multicolumn{1}{c}{7.6} \\
12 \\
Myrio- \\
phyllo- \\
Nuphar- \\
etum
\end{tabular} & $\begin{array}{l}\quad 6.7 \\
24 \\
\text { Spar- } \\
\text { ganio- } \\
\text { Elode- } \\
\text { etum }\end{array}$ & $\begin{array}{l}6.8 \\
219 \\
\text { Batra- } \\
\text { chieta- } \\
\text { lia }\end{array}$ & $\begin{array}{l}\quad 6.9 \\
212 \\
\text { Ranun- } \\
\text { culion } \\
\text { fluitan- } \\
\text { tis } \\
\end{array}$ & $\begin{array}{l}\quad 7.2 \\
95 \\
\text { Callitri- } \\
\text { cho-My- } \\
\text { riophyll- } \\
\text { etum } \\
\end{array}$ & 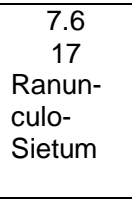 & $\begin{array}{c}5.6 \\
10 \\
\text { Ranun- } \\
\text { culetum } \\
\text { fluitantis }\end{array}$ & \begin{tabular}{l}
\multicolumn{1}{c}{3} \\
$\quad 1$ \\
Phrag- \\
mite- \\
tea
\end{tabular} \\
\hline \multicolumn{18}{|l|}{ Lemnetea } \\
\hline Spirodela polyrhiza & $11^{12}$ & $8^{12}$ & & $10^{11}$ & $10^{11}$ & $6^{15}$ & $31^{10}$ & . & $30^{9}$ & $42^{8}$ & $25^{9}$ & $5^{15}$ & $4^{9}$ & $1^{<1}$ & & & \\
\hline Lemna minor & $34^{10}$ & $37^{7}$ & $100^{<1}$ & $24^{10}$ & $25^{10}$ & $69^{6}$ & $46^{6}$ & . & $55^{6}$ & $83^{7}$ & $42^{4}$ & $30^{13}$ & $30^{11}$ & $22^{23}$ & $12^{63}$ & $30^{<1}$ & \\
\hline Lemna trisulca & $15^{6}$ & $17^{6}$ & & $20^{5}$ & $20^{5}$ & $13^{8}$ & $33^{6}$ & . & $38^{2}$ & $75^{2}$ & $25^{3}$ & $10^{4}$ & $10^{4}$ & $3^{<1}$ & . & $10^{<1}$ & \\
\hline \multirow{2}{*}{\multicolumn{18}{|c|}{ Potametea }} \\
\hline & & & & & & & & & & & & & & & & & \\
\hline Elodea canadensis & $40^{17}$ & $34^{18}$ & & $37^{22}$ & $35^{23}$ & $25^{8}$ & $27^{21}$ & & $25^{14}$ & $17^{20}$ & $33^{12}$ & $44^{15}$ & $43^{14}$ & $48^{15}$ & $6^{38}$ & $50^{14}$ & . \\
\hline Potamogeton natans & $31^{14}$ & $54^{12}$ & $100^{15}$ & $37^{12}$ & $38^{12}$ & $100^{13}$ & $58^{15}$ & $50^{3}$ & $68^{15}$ & $83^{12}$ & $54^{19}$ & $19^{14}$ & $19^{14}$ & $7^{14}$ & $6^{3}$ & $10^{1}$ & . \\
\hline Potamogeton crispus & $18^{8}$ & $27^{1}$ & & $15^{13}$ & $15^{13}$ & $63^{10}$ & $23^{6}$ & & $30^{6}$ & $33^{5}$ & $29^{7}$ & $16^{7}$ & $16^{6}$ & $9^{10}$ & $12^{9}$ & $10^{1}$ & . \\
\hline Ceratophyllum demersum & $6^{12}$ & $8^{2}$ & . & $10^{2}$ & $10^{2}$ & $6^{3}$ & $19^{14}$ & $50^{1}$ & $18^{13}$ & $33^{9}$ & $13^{18}$ & $2^{20}$ & $2^{20}$ & . & . & $10^{63}$ & . \\
\hline Persicaria amphibia & $2^{5}$ & $3^{8}$ & . & $5^{8}$ & $5^{8}$ & & $8^{2}$ & . & $8^{3}$ & $25^{3}$ & & $<1^{3}$ & . & . & . & & . \\
\hline \multicolumn{18}{|l|}{ Potametalia } \\
\hline Potamogeton acutifolius & & $2^{1}$ & & $2^{1}$ & $3^{1}$ & & & & & & & & & & . & & \\
\hline Potamogeton berchtoldii & $1^{3}$ & $2^{3}$ & & & & $6^{3}$ & $2^{3}$ & . & $3^{3}$ & & & $<1^{3}$ & . & & . & & . \\
\hline Potamogeton compressus & $1^{7}$ & $2^{73}$ & . & $2^{15}$ & $3^{15}$ & & $4^{27}$ & . & $3^{3}$ & $8^{3}$ & & & & & . & & \\
\hline Potamogeton pectinatus & $16^{24}$ & $24^{19}$ & . & $15^{26}$ & $13^{32}$ & $44^{11}$ & $17^{25}$ & . & $23^{25}$ & . & $25^{22}$ & $14^{25}$ & $15^{25}$ & $1^{15}$ & . & $20^{9}$ & . \\
\hline \multicolumn{18}{|l|}{ Potamion graminei } \\
\hline $\begin{array}{l}\text { Potamogeton } \\
\text { angustifolius }\end{array}$ & $<1^{63}$ & . & & . & . & . & . & . & . & . & . & $<1^{63}$ & . & $1^{63}$ & . & . & . \\
\hline Potamogeton obtusifolius & $1^{11}$ & $3^{1}$ & & $5^{1}$ & $5^{1}$ & & $2^{15}$ & . & & . & & $1^{19}$ & $1^{19}$ & & . & $20^{19}$ & \\
\hline Sparganium natans & $<1^{3}$ & $2^{3}$ & $100^{3}$ & . & . & . & . & . & 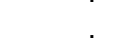 & . & t. & & & & . & & . \\
\hline Juncus bulbosus & $3^{3}$ & . & & . & . & . & & . & & . & & $4^{3}$ & $4^{3}$ & $9^{3}$ & . & $\cdot$ & . \\
\hline Potamogeton gramineus & $<1^{1}$ & . & & . & . & . & $2^{1}$ & . & $3^{1}$ & . & $4^{1}$ & . & . & . & . & . & . \\
\hline \multicolumn{18}{|l|}{ Potamion lucentis } \\
\hline Myriophyllum spicatum & $1^{3}$ & $5^{3}$ & . & $5^{3}$ & $5^{3}$ & $6^{3}$ & & & & . & . & 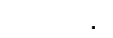 & . & . & . & . & . \\
\hline Ranunculus circinatus & $1^{5}$ & $5^{2}$ & & $7^{2}$ & $5^{3}$ & & $2^{15}$ & $50^{15}$ & & . & 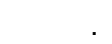 & . & . & . & . & & . \\
\hline \multicolumn{18}{|l|}{ Potametum lucentis } \\
\hline Potamogeton lucens & $11^{25}$ & $51^{28}$ & . & $73^{28}$ & $75^{28}$ & . & $4^{39}$ & . & $5^{39}$ & $17^{39}$ & & $2^{2}$ & $2^{2}$ & & . & & . \\
\hline Potamogeton perfoliatus & $13^{16}$ & $32^{21}$ & & $46^{21}$ & $48^{21}$ & & $10^{7}$ & . & $13^{7}$ & . & $17^{9}$ & $8^{13}$ & $8^{14}$ & $3^{18}$ & . & $50^{12}$ & \\
\hline
\end{tabular}




\begin{tabular}{|c|c|c|c|c|c|c|c|c|c|c|c|c|c|c|c|c|}
\hline $\begin{array}{l}\text { No. of species / relevé } \\
\text { No. of relevés }\end{array}$ & $\begin{array}{c}6.6 \\
336 \\
\text { Pota- } \\
\text { metea }\end{array}$ & $\begin{array}{l}6.4 \\
59 \\
\text { Pota- } \\
\text { meta- } \\
\text { lia }\end{array}$ & $\begin{array}{l}\quad 1 \\
\quad 1 \\
\text { Pota- } \\
\text { mion } \\
\text { grami- } \\
\text { nei } \\
\end{array}$ & $\begin{array}{l}5.2 \\
41 \\
\text { Pota- } \\
\text { mion } \\
\text { lucen- } \\
\text { tis }\end{array}$ & \begin{tabular}{l}
\multicolumn{1}{c}{5.2} \\
40 \\
Pota- \\
metum \\
lucen- \\
tis \\
\end{tabular} & $\begin{array}{c}9.6 \\
16 \\
\text { Pota- } \\
\text { mion } \\
\text { pusilli }\end{array}$ & $\begin{array}{c}6.2 \\
52 \\
\text { Nym- } \\
\text { phae- } \\
\text { etalia }\end{array}$ & $\begin{array}{l}3.5 \\
2 \\
\text { Hy- } \\
\text { dro- } \\
\text { cha- } \\
\text { rition }\end{array}$ & $\begin{array}{l}6.9 \\
40 \\
\text { Nym- } \\
\text { phae- } \\
\text { ion } \\
\text { albae } \\
\end{array}$ & \begin{tabular}{l}
\multicolumn{1}{c}{7.6} \\
12 \\
Myrio- \\
phyllo- \\
Nuphar- \\
etum
\end{tabular} & $\begin{array}{l}6.7 \\
24 \\
\text { Spar- } \\
\text { ganio- } \\
\text { Elode- } \\
\text { etum } \\
\end{array}$ & $\begin{array}{l}6.8 \\
219 \\
\text { Batra- } \\
\text { chieta- } \\
\text { lia }\end{array}$ & $\begin{array}{l}\quad 6.9 \\
212 \\
\text { Ranun- } \\
\text { culion } \\
\text { fluitan- } \\
\text { tis } \\
\end{array}$ & $\begin{array}{l}\quad 7.2 \\
\quad 95 \\
\text { Callitri- } \\
\text { cho-My- } \\
\text { riophyll- } \\
\text { etum }\end{array}$ & \begin{tabular}{l}
\multicolumn{1}{c}{7.6} \\
17 \\
Ranun- \\
culo- \\
Sietum
\end{tabular} & $\begin{array}{c}5.6 \\
10 \\
\text { Ranun- } \\
\text { culetum } \\
\text { fluitantis }\end{array}$ \\
\hline \multicolumn{17}{|l|}{ Potamion pusilli } \\
\hline Potamogeton pusillus & $7^{24}$ & $29^{30}$ & . & $5^{2}$ & $5^{2}$ & $94^{33}$ & $4^{26}$ & . & $5^{26}$ & $8^{38}$ & $4^{15}$ & $2^{2}$ & $2^{2}$ & $2^{2}$ & . & \\
\hline Potamogeton friesii & $10^{12}$ & $25^{21}$ & . & $5^{50}$ & $5^{50}$ & $81^{17}$ & $10^{4}$ & . & $13^{4}$ & $33^{1}$ & . & $5^{3}$ & $6^{3}$ & $2^{2}$ & . & \\
\hline \multicolumn{17}{|l|}{ Nymphaeetalia } \\
\hline Myriophyllum verticillatum & $1^{6}$ & $3^{2}$ & . & $5^{2}$ & $5^{2}$ & & $2^{15}$ & & $3^{15}$ & $8^{15}$ & & & . & & . & \\
\hline Utricularia vulgaris & $1^{19}$ & 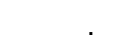 & . & & & & $4^{19}$ & $50^{38}$ & $3^{1}$ & & & & . & & . & \\
\hline \multicolumn{17}{|l|}{ Hydrocharition } \\
\hline $\begin{array}{l}\text { Hydrocharis morsus- } \\
\text { ranae }\end{array}$ & $2^{13}$ & $2^{15}$ & . & $2^{15}$ & $3^{15}$ & . & $8^{18}$ & $100^{20}$ & $5^{15}$ & $17^{15}$ & . & $1^{5}$ & $1^{5}$ & $1^{1}$ & . & $10^{1}$ \\
\hline \multicolumn{17}{|l|}{$\begin{array}{l}\text { Myriophyllo- } \\
\text { Nupharetum }\end{array}$} \\
\hline Nuphar lutea & $35^{21}$ & $37^{18}$ & . & $41^{16}$ & $43^{16}$ & $31^{24}$ & $88^{28}$ & . & $95^{30}$ & $100^{48}$ & $92^{22}$ & $22^{15}$ & $21^{16}$ & $11^{6}$ & $6^{1}$ & $20^{44}$ \\
\hline Sagittaria sagittifolia & $27^{12}$ & $36^{13}$ & . & $44^{15}$ & $45^{15}$ & $19^{1}$ & $56^{20}$ & & $68^{20}$ & $25^{7}$ & $96^{23}$ & $19^{7}$ & $20^{7}$ & $13^{3}$ & . & \\
\hline Sparganium emersum & $52^{19}$ & $36^{16}$ & . & $20^{12}$ & $20^{12}$ & $81^{19}$ & $42^{12}$ & & $55^{12}$ & $42^{2}$ & $58^{15}$ & $61^{20}$ & $63^{20}$ & $72^{13}$ & . & $60^{23}$ \\
\hline \multicolumn{17}{|l|}{ Batrachietalia } \\
\hline Callitriche palustris agg. & $42^{7}$ & $27^{4}$ & . & $2^{3}$ & $3^{3}$ & $94^{4}$ & $25^{8}$ & $50^{1}$ & $30^{9}$ & . & $50^{9}$ & $51^{8}$ & $52^{8}$ & $69^{9}$ & $53^{13}$ & $10^{1}$ \\
\hline Glyceria fluitans & $48^{7}$ & $22^{7}$ & . & $24^{8}$ & $25^{8}$ & $19^{2}$ & $4^{3}$ & . & $5^{3}$ & . & $8^{3}$ & $67^{7}$ & $66^{6}$ & $73^{7}$ & $82^{2}$ & $70^{4}$ \\
\hline Agrostis stolonifera & $32^{1}$ & $19^{1}$ & . & & . & $69^{1}$ & $10^{1}$ & . & $13^{1}$ & . & $17^{1}$ & $42^{1}$ & $43^{1}$ & $42^{1}$ & $82^{3}$ & \\
\hline \multicolumn{17}{|l|}{ Ranunculion fluitantis } \\
\hline Fontinalis antipyretica M & $7^{6}$ & . & . & & . & . & & . & . & . & . & $11^{6}$ & $11^{6}$ & $16^{7}$ & . & $20^{8}$ \\
\hline Potamogeton nodosus & $1^{63}$ & & . & & & & & & & & & $1^{63}$ & $1^{63}$ & & & \\
\hline Berula erecta & $28^{18}$ & $5^{7}$ & . & $7^{7}$ & $8^{7}$ & . & $8^{14}$ & . & $10^{14}$ & $8^{15}$ & $13^{14}$ & $40^{19}$ & $42^{19}$ & $36^{14}$ & $82^{31}$ & $30^{6}$ \\
\hline \multicolumn{17}{|l|}{$\begin{array}{l}\text { Callitricho- } \\
\text { Myriophylletum }\end{array}$} \\
\hline Callitriche hamulata & $23^{22}$ & & . & & & & & . & . & & . & $36^{22}$ & $37^{22}$ & $81^{22}$ & & $10^{3}$ \\
\hline $\begin{array}{l}\text { Myriophyllum } \\
\text { alterniflorum }\end{array}$ & $10^{16}$ & . & . & & . & . & & . & . & . & . & $15^{16}$ & $15^{16}$ & $34^{16}$ & . & \\
\hline Ranunculus aquatilis agg. & $24^{20}$ & $2^{3}$ & . & & & $<1^{3}$ & & & & & . & $36^{20}$ & $37^{20}$ & $82^{20}$ & . & \\
\hline Potamogeton alpinus & $5^{15}$ & $2^{3}$ & . & $2^{2}$ & $3^{3}$ & & $2^{3}$ & . & $3^{3}$ & $8^{3}$ & . & $7^{17}$ & $8^{17}$ & $17^{17}$ & . & \\
\hline \multicolumn{17}{|l|}{ Ranunculo-Sietum } \\
\hline Ranunculus trichophyllus & $1^{9}$ & $2^{15}$ & . & $2^{15}$ & $3^{15}$ & . & & . & . & . & . & $1^{7}$ & $1^{7}$ & & $18^{7}$ & \\
\hline Groenlandia densa & $1^{38}$ & . & . & & 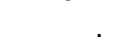 & . & & . & . & . & . & $1^{38}$ & $1^{38}$ & & $12^{38}$ & \\
\hline Zannichellia palustris & $4^{25}$ & & 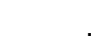 & & & 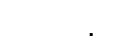 & & 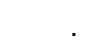 & . & 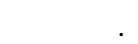 & . & $6^{99}$ & $7^{25}$ & $\cdot$ & $82^{25}$ & \\
\hline Hippuris vulgaris & $1^{1}$ & $2^{25}$ & . & $2^{1}$ & $3^{1}$ & . & & . & . & . & . & $1^{1}$ & $1^{1}$ & & $12^{1}$ & \\
\hline \multicolumn{17}{|l|}{ Ranunculetum fluitantis } \\
\hline Ranunculus fluitans & $5^{35}$ & & & & & & & & . & & . & $7^{35}$ & $8^{35}$ & $6^{38}$ & & $100^{33}$ \\
\hline
\end{tabular}




\begin{tabular}{|c|c|c|c|c|c|c|c|c|c|c|c|c|c|c|c|c|c|}
\hline $\begin{array}{l}\text { No. of species / relevé } \\
\text { No. of relevés }\end{array}$ & $\begin{array}{c}6.6 \\
336 \\
\text { Pota- } \\
\text { metea }\end{array}$ & $\begin{array}{l}6.4 \\
59 \\
\text { Pota- } \\
\text { meta- } \\
\text { lia }\end{array}$ & \begin{tabular}{l}
\multicolumn{1}{c}{6} \\
$\quad 1$ \\
Pota- \\
mion \\
grami- \\
nei \\
\end{tabular} & $\begin{array}{l}5.2 \\
41 \\
\text { Pota- } \\
\text { mion } \\
\text { lucen- } \\
\text { tis }\end{array}$ & $\begin{array}{l}5.2 \\
40 \\
\text { Pota- } \\
\text { metum } \\
\text { lucen- } \\
\text { tis } \\
\end{array}$ & $\begin{array}{c}9.6 \\
16 \\
\text { Pota- } \\
\text { mion } \\
\text { pusilli }\end{array}$ & $\begin{array}{c}6.2 \\
52 \\
\text { Nym- } \\
\text { phae- } \\
\text { etalia }\end{array}$ & $\begin{array}{l}3.5 \\
2 \\
\text { Hy- } \\
\text { dro- } \\
\text { cha- } \\
\text { rition } \\
\end{array}$ & $\begin{array}{l}6.9 \\
40 \\
\text { Nym- } \\
\text { phae- } \\
\text { ion } \\
\text { albae }\end{array}$ & \begin{tabular}{l}
\multicolumn{1}{c}{7.6} \\
12 \\
Myrio- \\
phyllo- \\
Nuphar- \\
etum
\end{tabular} & $\begin{array}{l}6.7 \\
24 \\
\text { Spar- } \\
\text { ganio- } \\
\text { Elode- } \\
\text { etum } \\
\end{array}$ & $\begin{array}{l}6.8 \\
219 \\
\text { Batra- } \\
\text { chieta- } \\
\text { lia }\end{array}$ & $\begin{array}{l}\quad 6.9 \\
212 \\
\text { Ranun- } \\
\text { culion } \\
\text { fluitan- } \\
\text { tis } \\
\end{array}$ & $\begin{array}{l}\quad 7.2 \\
\quad 95 \\
\text { Callitri- } \\
\text { cho-My- } \\
\text { riophyll- } \\
\text { etum }\end{array}$ & $\begin{array}{l}7.6 \\
17 \\
\text { Ranun- } \\
\text { culo- } \\
\text { Sietum }\end{array}$ & $\begin{array}{c}5.6 \\
10 \\
\text { Ranun- } \\
\text { culetum } \\
\text { fluitantis }\end{array}$ & \begin{tabular}{l}
\multicolumn{1}{c}{3} \\
$\quad 1$ \\
Phrag- \\
mite- \\
tea
\end{tabular} \\
\hline \multicolumn{18}{|l|}{ Phragmitetea } \\
\hline Typha latifolia & $<1^{15}$ & & & & & . & & & . & & . & $<1^{15}$ & & . & & . & \\
\hline Phragmites australis & $1^{5}$ & $2^{1}$ & & $2^{1}$ & & & $2^{15}$ & & & . & & & & & & . & $100^{1}$ \\
\hline Sparganium erectum & $8^{6}$ & $8^{7}$ & $100^{1}$ & $2^{15}$ & $3^{15}$ & $19^{7}$ & $6^{7}$ & & $5^{3}$ & . & $8^{3}$ & $9^{6}$ & $9^{6}$ & $2^{38}$ & $24^{3}$ & . & $100^{<1}$ \\
\hline Alisma plantago-aquatica & $8^{3}$ & $8^{1}$ & $100^{1}$ & $2^{1}$ & $3^{1}$ & $19^{1}$ & $6^{5}$ & & $8^{5}$ & & $13^{5}$ & $8^{4}$ & $8^{4}$ & $6^{8}$ & $6^{1}$ & . & \\
\hline Glyceria maxima & $6^{13}$ & $7^{21}$ & . & $10^{21}$ & $10^{21}$ & . & $12^{4}$ & & $10^{6}$ & $8^{3}$ & $13^{7}$ & $5^{15}$ & $5^{15}$ & $3^{18}$ & 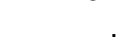 & . & $100^{<1}$ \\
\hline Rumex hydrolapathum & $<1^{15}$ & & & & & & & & & & & $<1^{15}$ & & & & & \\
\hline Sium latifolium & $1^{14}$ & . & . & & & . & $4^{9}$ & & $5^{9}$ & . & $8^{9}$ & $1^{20}$ & $1^{20}$ & $1^{3}$ & & & \\
\hline Schoenoplectus lacustris & $1^{2}$ & & . & & & & & & & . & - & $2^{56}$ & $1^{2}$ & & & $10^{3}$ & \\
\hline Butomus umbellatus & $13^{8}$ & $19^{8}$ & . & $10^{5}$ & $8^{7}$ & $44^{9}$ & $12^{14}$ & & $3^{1}$ & . & . & $11^{6}$ & $11^{7}$ & $1^{3}$ & & $10^{3}$ & \\
\hline Mentha aquatica & $6^{6}$ & & . & & & . & 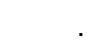 & & . & . & . & $9^{6}$ & $9^{6}$ & $9^{1}$ & $35^{3}$ & . & \\
\hline Veronica beccabunga & $6^{3}$ & $2^{15}$ & . & $2^{15}$ & $3^{15}$ & . & . & & . & . & . & $9^{3}$ & $9^{3}$ & $1^{15}$ & $76^{2}$ & . & \\
\hline $\begin{array}{l}\text { Veronica anagallis- } \\
\text { aquatica }\end{array}$ & $8^{7}$ & . & . & & . & . & . & & . & . & . & $12^{7}$ & $12^{7}$ & $8^{8}$ & $76^{7}$ & . & \\
\hline Nasturtium officinale & $1^{5}$ & . & . & & . & . & . & & . & . & . & $2^{5}$ & $2^{5}$ & & $18^{2}$ & . & \\
\hline Glyceria notata (G.plicata) & $<1^{1}$ & & . & & & . & & & & . & & $<1^{1}$ & & $1^{1}$ & 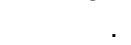 & . & \\
\hline Phalaris arundinacea & $2^{9}$ & $2^{15}$ & . & $2^{15}$ & $3^{15}$ & . & $4^{15}$ & & $5^{15}$ & . & $8^{15}$ & $2^{5}$ & $2^{5}$ & $1<1$ & & . & \\
\hline Carex acutiformis & $<1^{1}$ & $2^{1}$ & . & $2^{1}$ & $3^{1}$ & . & 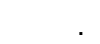 & & . & . & . & & & 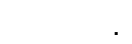 & & . & \\
\hline \multicolumn{18}{|l|}{ Fontinalietea } \\
\hline $\begin{array}{l}\text { Platyhypnidium } \\
\text { riparioides M }\end{array}$ & $4^{2}$ & $2^{1}$ & . & $2^{1}$ & $3^{1}$ & . & . & & . & . & . & $5^{2}$ & $6^{2}$ & . & $59^{1}$ & . & \\
\hline Amblystegium riparium $\mathrm{M}$ & $6^{4}$ & . & . & . & . & . & . & & . & . & . & $9^{4}$ & $9^{4}$ & $17^{4}$ & . & . & \\
\hline $\begin{array}{l}\text { Chiloscyphus polyanthos } \\
\text { M }\end{array}$ & $1^{26}$ & . & . & . & . & . & . & & . & . & . & $2^{26}$ & $2^{26}$ & $5^{26}$ & . & . & \\
\hline \multicolumn{18}{|l|}{ Accompanying species } \\
\hline Apium inundatum & $<1^{3}$ & & . & & & . & . & & . & . & . & $<1^{3}$ & . & $1^{3}$ & . & . & \\
\hline $\begin{array}{l}\text { Callitriche } \\
\text { hermaphroditica }\end{array}$ & $1^{6}$ & $3^{3}$ & . & $5^{3}$ & $5^{3}$ & . & . & & . & . & . & $<1^{3}$ & . & . & . & . & \\
\hline Isolepis fluitans & $1^{21}$ & $3^{15}$ & & $2^{15}$ & $3^{15}$ & $6^{15}$ & $2^{38}$ & & $3^{38}$ & . & $4^{38}$ & $<1^{15}$ & . & $1^{15}$ & . & . & \\
\hline Luronium natans & $<1^{38}$ & $2^{38}$ & $100^{38}$ & & & 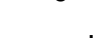 & - & & - & . & . & & 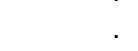 &. & & . & \\
\hline Potamogeton filiformis & $1^{8}$ & $2^{1}$ & . & $2^{1}$ & $3^{1}$ & . & & & . & & . & & & & . & . & \\
\hline $\begin{array}{l}\text { Potamogeton } \\
\text { polygonifolius }\end{array}$ & $1^{39}$ & . & . & & . & . & . & & . & . & . & $1^{39}$ & $1^{39}$ & $1^{15}$ & . & . & \\
\hline Utricularia australis & $<1^{15}$ & & & & & & $2^{15}$ & & $3^{15}$ & $8^{15}$ & . & & & & & . & \\
\hline
\end{tabular}


Table 4.1b Macrophyte vegetation of north-west German running waters in 2010/2011 as classified after Preising et al. (1990). Relevés assigned to lower levels than the class belong to several groups; 332 relevés are included. No specific character species is attributed to the Nymphaeion albae, which is characterized by differential species. Base figures: relative frequency of species occurrence within a group in percent; exponents: cover values as averages within groups

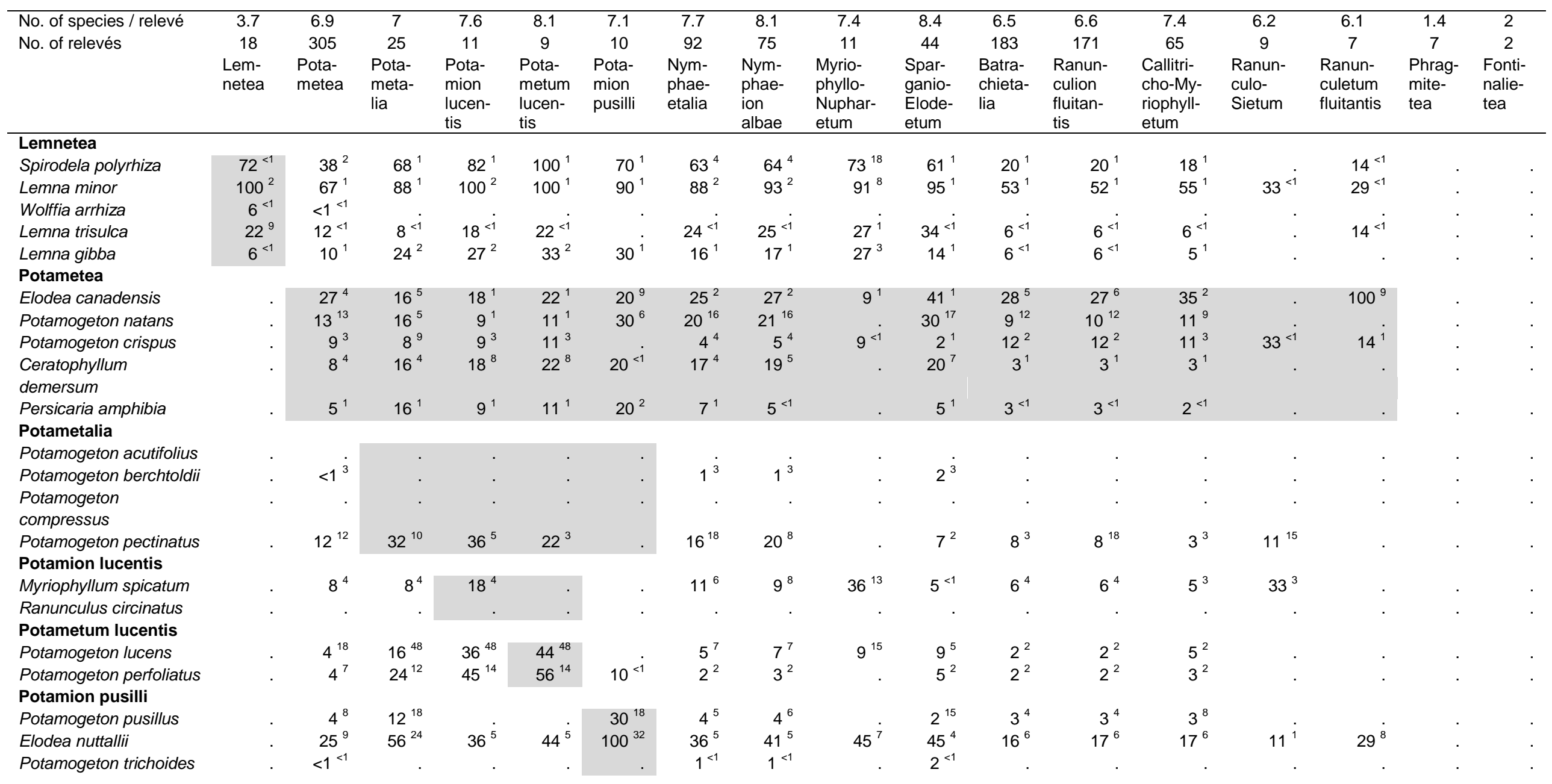




\begin{tabular}{|c|c|c|c|c|c|c|c|c|c|c|c|c|c|c|c|c|c|}
\hline $\begin{array}{l}\text { No. of species / relevé } \\
\text { No. of relevés }\end{array}$ & $\begin{array}{c}3.7 \\
18 \\
\text { Lem- } \\
\text { netea }\end{array}$ & $\begin{array}{c}6.9 \\
305 \\
\text { Pota- } \\
\text { metea }\end{array}$ & \begin{tabular}{l}
\multicolumn{1}{c}{7} \\
25 \\
Pota- \\
meta- \\
lia
\end{tabular} & \begin{tabular}{l}
\multicolumn{1}{c}{7.6} \\
11 \\
Pota- \\
mion \\
lucen- \\
tis \\
\end{tabular} & \begin{tabular}{l}
\multicolumn{1}{c}{8.1} \\
$\quad 9$ \\
Pota- \\
metum \\
lucen- \\
tis \\
\end{tabular} & $\begin{array}{l}7.1 \\
10 \\
\text { Pota- } \\
\text { mion } \\
\text { pusilli }\end{array}$ & $\begin{array}{c}7.7 \\
92 \\
\text { Nym- } \\
\text { phae- } \\
\text { etalia }\end{array}$ & $\begin{array}{l}8.1 \\
75 \\
\text { Nym- } \\
\text { phae- } \\
\text { ion } \\
\text { albae } \\
\end{array}$ & \begin{tabular}{l}
\multicolumn{1}{c}{7.4} \\
11 \\
Myrio- \\
phyllo- \\
Nuphar- \\
etum \\
\end{tabular} & $\begin{array}{l}8.4 \\
44 \\
\text { Spar- } \\
\text { ganio- } \\
\text { Elode- } \\
\text { etum } \\
\end{array}$ & $\begin{array}{l}6.5 \\
183 \\
\text { Batra- } \\
\text { chieta- } \\
\text { lia }\end{array}$ & $\begin{array}{l}\quad 6.6 \\
\quad 171 \\
\text { Ranun- } \\
\text { culion } \\
\text { fluitan- } \\
\text { tis } \\
\end{array}$ & \begin{tabular}{l}
\multicolumn{1}{c}{7.4} \\
$\quad 65$ \\
Callitri- \\
cho-My- \\
riophyll- \\
etum \\
\end{tabular} & 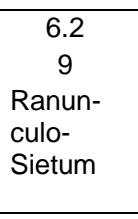 & $\begin{array}{c}6.1 \\
7 \\
\text { Ranun- } \\
\text { culetum } \\
\text { fluitantis }\end{array}$ & $\begin{array}{l}1.4 \\
\quad 7 \\
\text { Phrag- } \\
\text { mite- } \\
\text { tea }\end{array}$ & \begin{tabular}{l}
\multicolumn{1}{c}{2} \\
2 \\
Fonti- \\
nalie- \\
tea
\end{tabular} \\
\hline Nymphaeetalia & & & & & & & & & & & & & & & & & \\
\hline $\begin{array}{l}\text { Myriophyllum } \\
\text { verticillatum }\end{array}$ & . & $<1^{1}$ & . & . & . & . & & & . & & 11 & $1^{1}$ & $2^{1}$ & . & . & . & \\
\hline $\begin{array}{l}\text { Utricularia vulgaris } \\
\text { Hydrocharition }\end{array}$ & . & $3^{5}$ & . & . & . & . & $10^{5}$ & $11^{6}$ & $27^{8}$ & $2^{5}$ & $1^{3}$ & $1^{3}$ & . & . & . & . & \\
\hline $\begin{array}{l}\text { Hydrocharition } \\
\text { Hydrocharis morsus- } \\
\text { ranae } \\
\text { Myriophyllo- } \\
\text { Nupharetum }\end{array}$ & . & $4^{2}$ & $12^{1}$ & $18^{1}$ & $22^{1}$ & $10^{<1}$ & $9^{2}$ & $8^{3}$ & $9^{15}$ & $5^{<1}$ & $1^{2}$ & $1^{2}$ & . & . & . & . & \\
\hline $\begin{array}{l}\text { Nuphar lutea } \\
\text { Sparganio-Elodeetum }\end{array}$ & . & $33^{11}$ & $20^{15}$ & $36^{15}$ & $44^{15}$ & $10^{15}$ & $77^{12}$ & $77^{13}$ & $82^{32}$ & $77^{11}$ & $13^{6}$ & $14^{6}$ & $9^{4}$ & . & . & . & \\
\hline $\begin{array}{l}\text { Sagittaria sagittifolia } \\
\text { Sparganium emersum }\end{array}$ & . & $\begin{array}{r}29^{12} \\
64^{8}\end{array}$ & $\begin{array}{r}36^{21} \\
52^{8}\end{array}$ & $\begin{array}{r}45^{25} \\
55^{8}\end{array}$ & $\begin{array}{r}56^{25} \\
44^{7}\end{array}$ & $\begin{array}{r}40^{17} \\
40^{9}\end{array}$ & $\begin{array}{r}70^{12} \\
51^{6}\end{array}$ & $\begin{array}{r}83^{12} \\
52^{6}\end{array}$ & $\begin{array}{l}45^{13} \\
36^{14}\end{array}$ & $\begin{array}{r}98^{14} \\
52^{5}\end{array}$ & $\begin{array}{r}9^{8} \\
74^{9}\end{array}$ & $\begin{array}{l}10^{8} \\
77^{9}\end{array}$ & $\begin{array}{l}8^{12} \\
92^{8}\end{array}$ & $22^{2}$ & $86^{5}$ & . & \\
\hline Batrachietalia & & & & & & & & & & & & & & & & & \\
\hline $\begin{array}{l}\text { Callitriche palustris agg. } \\
\text { Glyceria fluitans } \\
\text { Agrostis stolonifera }\end{array}$ & $33^{<1}$ & $\begin{array}{r}44^{2} \\
8^{4} \\
15^{<1}\end{array}$ & $24^{1}$ & $9^{3}$ & $11^{3}$ & $50^{1}$ & $\begin{array}{r}35^{1} \\
2^{3} \\
4^{<1}\end{array}$ & $\begin{array}{r}43^{1} \\
3^{3} \\
4^{<1}\end{array}$ & $\begin{array}{l}27^{<1} \\
27^{<1}\end{array}$ & $\begin{array}{r}50^{1} \\
5^{3}\end{array}$ & $\begin{array}{l}52^{3} \\
12^{4} \\
22^{1}\end{array}$ & $\begin{array}{r}53^{3} \\
9^{5} \\
21^{<1}\end{array}$ & $\begin{array}{r}72^{4} \\
15^{2} \\
9^{1}\end{array}$ & $\begin{array}{l}44^{4} \\
22^{<1}\end{array}$ & $57^{1}$ & . & \\
\hline Ranunculion fluitantis & & & & & & & & & & & & & & & & & \\
\hline $\begin{array}{l}\text { Fontinalis antipyretica M } \\
\text { Potamogeton nodosus } \\
\text { Berula erecta }\end{array}$ & . & $\begin{array}{r}6^{4} \\
1^{4} \\
23^{6}\end{array}$ & . & . & . & . & $\begin{array}{l}1^{3} \\
3^{1}\end{array}$ & $\begin{array}{l}1^{3} \\
4^{1}\end{array}$ & $9^{i}$ & $\begin{array}{l}2^{3} \\
5^{2}\end{array}$ & $\begin{array}{r}10^{4} \\
1^{5} \\
36^{6}\end{array}$ & $\begin{array}{r}11^{4} \\
1^{5} \\
38^{6}\end{array}$ & $\begin{array}{r}12^{1} \\
2^{5} \\
28^{4}\end{array}$ & $\begin{array}{l}33^{<1} \\
22^{46}\end{array}$ & $29^{1}$ & . & $50^{<1}$. \\
\hline $\begin{array}{l}\text { Callitricho- } \\
\text { Myriophylletum }\end{array}$ & & & & & & & & & & & & & & & & & \\
\hline $\begin{array}{l}\text { Callitriche hamulata } \\
\text { Myriophyllum } \\
\text { alterniflorum }\end{array}$ & . & $\begin{array}{r}16^{2} \\
6^{2}\end{array}$ & . & . & . & . & $3^{<1}$ & $4^{<1}$ & $9^{<1}$ & $5^{1}$ & $\begin{array}{l}26^{2} \\
10^{2}\end{array}$ & $\begin{array}{l}27^{2} \\
10^{2}\end{array}$ & $\begin{array}{l}66^{2} \\
26^{3}\end{array}$ & $11^{3}$ & $\begin{array}{l}29^{<1} \\
14^{<1}\end{array}$ & . & \\
\hline $\begin{array}{l}\text { Ranunculus aquatilis } \\
\text { agg. } \\
\text { Ranunculo-Sietum }\end{array}$ & . & $10^{7}$ & . & . & . & . & . & & . & . & $17^{7}$ & $19^{7}$ & $49^{7}$ & . & . & . & \\
\hline $\begin{array}{l}\text { Ranunculus } \\
\text { trichophyllus }\end{array}$ & . & $2^{4}$ & . & . & . & . & . & . & . & . & $4^{4}$ & $4^{4}$ & $2^{<1}$ & $67^{4}$ & . & . & \\
\hline Groenlandia densa & . & $<1^{1}$ & . & . & . & . & . & & . & . & $1^{1}$ & $1^{1}$ & . & $11^{1}$ & . & . & \\
\hline $\begin{array}{l}\text { Zannichellia palustris } \\
\text { Ranunculetum } \\
\text { fluitantis }\end{array}$ & . & $1^{1}$ & . & . & . & . & . & & . & . & 21 & $2^{1}$ & . & $22^{1}$ & . & . & \\
\hline Ranunculus fluitans & . & $3^{12}$ & . & . & . & . & . & & . & . & $4^{12}$ & $5^{12}$ & $2^{3}$ & & $100^{13}$ & . & \\
\hline
\end{tabular}




\begin{tabular}{|c|c|c|c|c|c|c|c|c|c|c|c|c|c|c|c|c|c|}
\hline No. of species / relevé & 3.7 & 6.9 & 7 & 7.6 & 8.1 & 7.1 & 7.7 & 8.1 & 7.4 & 8.4 & 6.5 & 6.6 & 7.4 & 6.2 & 6.1 & 1.4 & \multirow{3}{*}{$\begin{array}{l}\quad 2 \\
\text { Fonti- } \\
\text { nalie- } \\
\text { tea }\end{array}$} \\
\hline \multirow{2}{*}{ No. of relevés } & 18 & 305 & 25 & 11 & 9 & 10 & 92 & 75 & 11 & 44 & 183 & 171 & 65 & 9 & 7 & 7 & \\
\hline & $\begin{array}{l}\text { Lem- } \\
\text { netea }\end{array}$ & $\begin{array}{l}\text { Pota- } \\
\text { metea }\end{array}$ & $\begin{array}{l}\text { Pota- } \\
\text { meta- } \\
\text { lia }\end{array}$ & $\begin{array}{l}\text { Pota- } \\
\text { mion } \\
\text { lucen- } \\
\text { tis } \\
\end{array}$ & $\begin{array}{l}\text { Pota- } \\
\text { metum } \\
\text { lucen- } \\
\text { tis } \\
\end{array}$ & $\begin{array}{l}\text { Pota- } \\
\text { mion } \\
\text { pusilli }\end{array}$ & $\begin{array}{l}\text { Nym- } \\
\text { phae- } \\
\text { etalia }\end{array}$ & $\begin{array}{l}\text { Nym- } \\
\text { phae- } \\
\text { ion } \\
\text { albae } \\
\end{array}$ & $\begin{array}{l}\text { Myrio- } \\
\text { phyllo- } \\
\text { Nuphar- } \\
\text { etum }\end{array}$ & $\begin{array}{l}\text { Spar- } \\
\text { ganio- } \\
\text { Elode- } \\
\text { etum } \\
\end{array}$ & $\begin{array}{l}\text { Batra- } \\
\text { chieta- } \\
\text { lia }\end{array}$ & $\begin{array}{l}\text { Ranun- } \\
\text { culion } \\
\text { fluitan- } \\
\text { tis } \\
\end{array}$ & $\begin{array}{l}\text { Callitri- } \\
\text { cho-My- } \\
\text { riophyll- } \\
\text { etum }\end{array}$ & $\begin{array}{l}\text { Ranun- } \\
\text { culo- } \\
\text { Sietum }\end{array}$ & $\begin{array}{l}\text { Ranun- } \\
\text { culetum } \\
\text { fluitantis }\end{array}$ & $\begin{array}{l}\text { Phrag- } \\
\text { mite- } \\
\text { tea }\end{array}$ & \\
\hline \multicolumn{18}{|l|}{ Phragmitetea } \\
\hline Iris pseudacorus & $6^{<1}$ & $2^{1}$ & & & & & & & . & & $4^{1}$ & $4^{1}$ & $3^{<1}$ & $11^{1}$ & . & & \\
\hline Phragmites australis & $33^{10}$ & $9^{5}$ & $16^{4}$ & $9^{15}$ & $11^{15}$ & $20^{1}$ & $10^{2}$ & $5^{2}$ & & $2^{1}$ & $7^{8}$ & $7^{8}$ & $3^{2}$ & . & . & $43^{9}$ & . \\
\hline Sparganium erectum & $33^{26}$ & $32^{5}$ & $20^{10}$ & $9^{15}$ & . & $10^{15}$ & $43^{5}$ & $45^{4}$ & $55^{8}$ & $45^{3}$ & $27^{5}$ & $26^{5}$ & $22^{2}$ & . & & & \\
\hline $\begin{array}{l}\text { Alisma plantago- } \\
\text { aquatica }\end{array}$ & . & $3^{1}$ & $4^{<1}$ & . & . & $10^{<1}$ & $4^{<1}$ & $5^{<1}$ & . & $7^{<1}$ & $3^{1}$ & $3^{1}$ & $3^{3}$ & . & $14^{1}$ & & \\
\hline Glyceria maxima & $17^{10}$ & $17^{3}$ & $20^{3}$ & $18^{3}$ & $22^{3}$ & $30^{3}$ & $25^{4}$ & $24^{4}$ & $18^{8}$ & $23^{4}$ & $13^{2}$ & $13^{2}$ & $15^{2}$ & . & $14^{3}$ & $14^{<1}$ & . \\
\hline Rumex hydrolapathum & . & $3^{<1}$ & . & . & . & . & $5^{<1}$ & $7^{<1}$ & $9^{1}$ & $5^{<1}$ & $2^{1}$ & $1^{1}$ & $2^{1}$ & . & . & . & . \\
\hline Sium latifolium & . & $1^{5}$ & . & . & . & . & & & & . & $2^{5}$ & $2^{5}$ & $2^{15}$ & . & . & . & 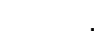 \\
\hline $\begin{array}{l}\text { Schoenoplectus } \\
\text { lacustris }\end{array}$ & . & $1^{1}$ & . & . & . & . & 111 & $1^{1}$ & $9^{1}$ & & 133 & $1^{2}$ & & & . & & \\
\hline Butomus umbellatus & & $13^{3}$ & $8^{9}$ & $9^{15}$ & $11^{15}$ & $10^{3}$ & $18^{3}$ & $19^{3}$ & $9^{1}$ & $18^{5}$ & $11^{3}$ & $12^{3}$ & $3^{9}$ & & . & & \\
\hline Mentha aquatica & $6^{5}$ & $6^{3}$ & . & . & 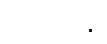 & . & & & . & & $9^{3}$ & $9^{4}$ & $9^{1}$ & $11^{38}$ & & $14^{1}$ & \\
\hline Veronica beccabunga & . & $6^{1}$ & . & . & . & . & $1^{1}$ & $1^{1}$ & . & $2^{1}$ & $9^{1}$ & $9^{1}$ & $9^{1}$ & $44^{<1}$ & $14^{<1}$ & $14^{1}$ & . \\
\hline $\begin{array}{l}\text { Veronica anagallis- } \\
\text { aquatica }\end{array}$ & . & $3^{<1}$ & . & . & . & . & $2^{<1}$ & $1^{<1}$ & . & $2^{<1}$ & $4^{<1}$ & $4^{<1}$ & $3^{<1}$ & $44^{<1}$ & . & . & . \\
\hline Mimulus guttatus & . & $1^{2}$ & . & . & . & . & & & . & . & $1^{2}$ & & & & . & . & \\
\hline Nasturtium officinale & & $7^{7}$ & & & & & $2^{<1}$ & & & & $11^{8}$ & $12^{8}$ & $14^{3}$ & $22^{44}$ & & & \\
\hline Phalaris arundinacea & $28^{4}$ & $58^{2}$ & $68^{2}$ & $82^{1}$ & $78^{1}$ & $60^{2}$ & $48^{3}$ & $48^{3}$ & $36^{5}$ & $52^{3}$ & $61^{2}$ & $61^{2}$ & $66^{2}$ & $89^{1}$ & $57^{<1}$ & $14^{3}$ & \\
\hline Carex acutiformis & & $<1^{<1}$ & . & . & . & . & . & . & . & . & $1^{<1}$ & $1^{<1}$ & . & . & . & & . \\
\hline Carex riparia & $6^{3}$ & & . & . & . & . & . & & . & & . & & . & & & $29^{<1}$ & \\
\hline Fontinalietea & & & & & & & & & & & & & & & & & \\
\hline $\begin{array}{l}\text { Platyhypnidium } \\
\text { riparioides M }\end{array}$ & . & $4^{5}$ & $4^{1}$ & $\cdot$ & . & $\cdot$ & . & . & $\cdot$ & . & $7^{6}$ & $6^{6}$ & $5^{<1}$ & $22^{1}$ & . & $14^{15}$ & $50^{75}$ \\
\hline $\begin{array}{l}\text { Chiloscyphus } \\
\text { polyanthos M } \\
\text { Accompanying } \\
\text { species }\end{array}$ & . & $1^{4}$ & . & . & . & . & . & . & . & . & $2^{4}$ & $2^{4}$ & $2^{<1}$ & . & . & . & $100^{1}$ \\
\hline $\begin{array}{l}\text { Callitriche } \\
\text { hermaphroditica }\end{array}$ & 61 & . & . & . & . & . & . & . & $\cdot$ & . & . & . & . & . & . & . & \\
\hline Isolepis fluitans & . & $<1^{1}$ & . & . & . & . & & & . & & $1^{1}$ & $1^{1}$ & $2^{1}$ & . & . & . & \\
\hline $\begin{array}{l}\text { Potamogeton } \\
\text { praelongus }\end{array}$ & . & $1^{3}$ & . & . & . & . & $1^{3}$ & $1^{3}$ & . & $2^{3}$ & $1^{3}$ & $1^{3}$ & 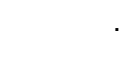 & . & . & . & \\
\hline
\end{tabular}


Table 4.5 Correlation coefficients after Spearman and $p$ values of the relationships between environmental variables and DCA axes 1 and 2 for a total of 650 relevés that were used for the trajectory analysis

\begin{tabular}{lrcrr}
\hline Parameter & r DCA axis 1 & p & r DCA axis 2 & \multicolumn{1}{c}{ p } \\
\hline Current velocity & 0.13 & ${ }^{* * *}<0.001$ & 0.23 & ${ }^{* * *}<0.001$ \\
Reach width & -0.30 & ${ }^{* * *}<0.001$ & -0.16 & ${ }^{* * *}<0.001$ \\
Reach depth & -0.35 & ${ }^{* * *}<0.001$ & -0.07 & 0.058 \\
EIV - temperature & -0.29 & ${ }^{* * *}<0.001$ & 0.04 & 0.330 \\
EIV - soil reaction & -0.04 & 0.270 & 0.16 & ${ }^{* * *}<0.001$ \\
EIV - nutrients & -0.21 & ${ }^{* * *}<0.001$ & 0.07 & 0.085 \\
\hline
\end{tabular}

Table 4.7 Correlation coefficients after Spearman and $p$ values of the relationships between environmental variables and DCA axes 1 and 2 for 70 streams or rivers (1950s and 2010/2011)

\begin{tabular}{lrcrr}
\hline Parameter & r DCA axis 1 & p & r DCA axis 2 & p \\
\hline Current velocity & 0.49 & ${ }^{* * *}<0.001$ & 0.16 & 0.095 \\
Reach width & -0.21 & ${ }^{*} 0.026$ & 0.21 & ${ }^{*} 0.028$ \\
Reach depth & -0.41 & ${ }^{* * *}<0.001$ & 0.15 & 0.118 \\
EIV - temperature & -0.58 & ${ }^{* * *}<0.001$ & 0.24 & ${ }^{* *} 0.004$ \\
EIV - soil reaction & -0.16 & 0.053 & -0.18 & ${ }^{*} 0.033$ \\
EIV - nutrients & -0.27 & ${ }^{* * *}<0.001$ & -0.22 & ${ }^{*} 0.010$ \\
\hline
\end{tabular}




\section{Acknowledgments}

In the first place, I thank Christoph Leuschner, who gave me the opportunity to work on an interesting research topic, for the motivating discussions, for his ideas and constant support during the last three and a half years. To Markus Hauck I'm thankful for accepting acting as second examiner and for helpful advice. I thank Thomas Becker for initiating the water chemistry study, for his advice on statistical methods and for steadily being open to discussion. To Uta Müller I'm thankful for her help and company in the field work; she also carried out a large part of the chemical analyses for her master's thesis.

I'm thankful to Günther Dersch for sharing some of his knowledge about the collection, the cultivation and the identification of Callitriche species with me, for the cytological identification of more than 50 plants and also to Gisela Dersch for their kind hospitality. To Sebastian Dittrich I'm thankful for the identification of bryophytic species and inspiring discussions. In the initial phase of the study, Karsten Wesche kindly helped with the sampling design and later on he gave advice on statistical practices. Helpful recommendations on the data processing also came from Jürgen Homeier. To Uta NüsseHahne, Ute Schlonsog, Marianne Gscheidlen and Jutta Czernitzki I'm thankful for their help with the chemical analyses. Volkert Andrees-Junge $(\dagger)$ constructed my practical telescopic macrophyte rake. I also thank my "predecessors" Gerhard Wiegleb and Wolfgang Herr, who contributed to the chapters two or three as coauthors. Werner Cohrs (Zum Örtzewinkel) and Jutta Leckermeyer-Hannker (Dümmer See Camping) kindly provided freezing facilities.

With Heiko Brunken, Matthias Hein and Gert Weber I had enlightening discussions on freshwater ecology related questions. I'm also thankful to Stefan Meyer and Sebastian Schuch for our successful teamwork, to my roommate Mascha Jacob for sharing working hours of the happy kind, to Ina Meier, Astrid Rodriguez and Dirk Gansert for valuable advice and to the members of the Plant Ecology department for the good collegiality. Without Dietmar Zacharias, who introduced me to vegetation ecology, and Uwe Starfinger, who drew my attention to the unexplored side of hydrophytes, this piece of work would not exist. Finally, I thank Jas, Kathy, Bine, Marco, Melle and my family, who were invaluably supportive in many different ways. 